SIMULATION OF GROUND-WATER FLOW IN

THE MESILLA BASIN, DOÑA ANA COUNTY, NEW MEXICO,

AND EL PASO COUNTY, TEXAS

SUPPLEMENT TO OPEN-FILE REPORT 88-305

By Peter F. Frenzel

U.S. GEOLOGICAL SURVEY

Water-Resources Investigations Report 91-4155

Prepared in cooperation with the

U.S. SECTION, INTERNATIONAL BOUNDARY AND WATER COMMISSION--

United States and Mexico

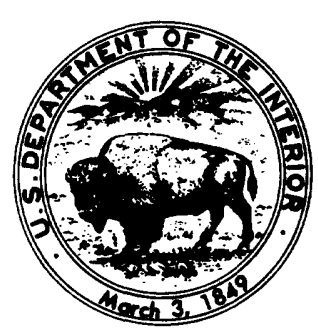

Albuquerque, New Mexico

1992 
U.S. DEPARTMENT OF THE INTERIOR

MANUEL LUJAN, JR., Secretary

U.S. GEOLOGICAL SURVEY

Dallas L. Peck, Director

For additional information write to:

District Chief U.S. Geological Survey Pinetree Corporate Centre Water Resources Division 4501 Indian School Rd. NE, Suite 200 Albuquerque, New Mexico 87110
Copies of this report can be purchased from:

U.S. Geological Survey Books and Open-File Reports Federal Center

Box 25425

Denver, Colorado 80225 
Abstract................................... 1

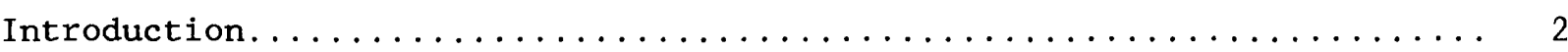

Purpose and scope............................... 4

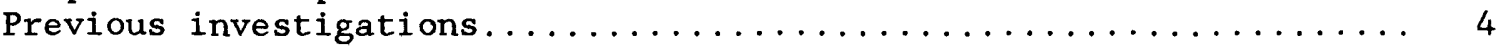

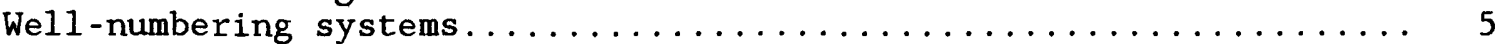

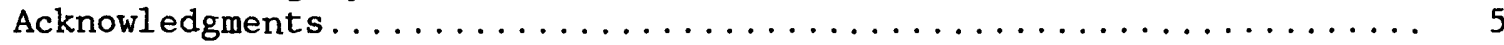

Description of the Mesilla Basin..................... 8

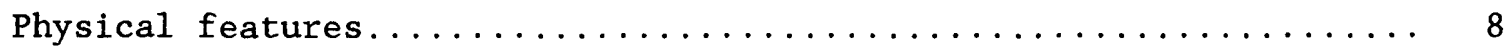

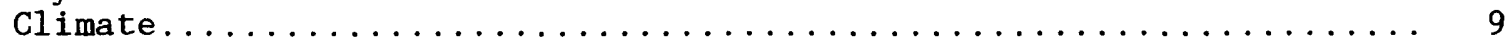

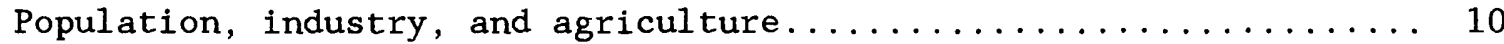

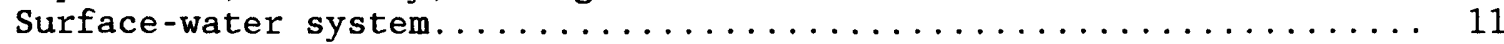

Ground-water system............................ 11

Hydrogeology of the basin-fill deposits............. 12

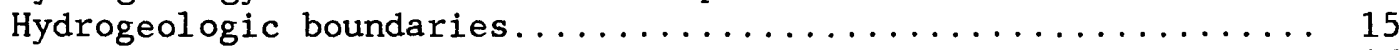

Mesilla Valley boundary...................... 16

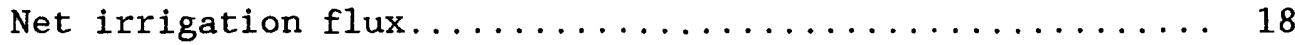

Evapotranspiration from nonirrigated lands........... 21

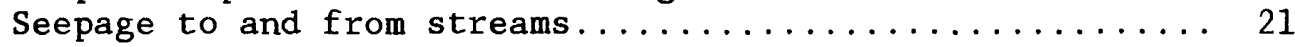

Nonirrigation withdrawals and returns............. 22

Mountain- and slope-front recharge.............. 24

Summary of geohydrology ..................... 24

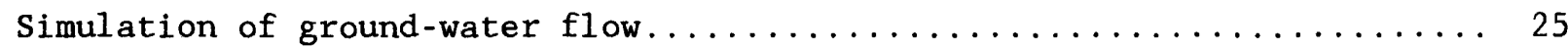

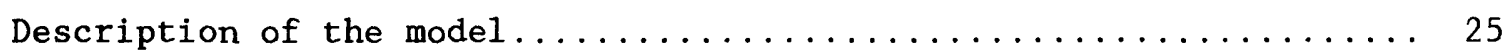

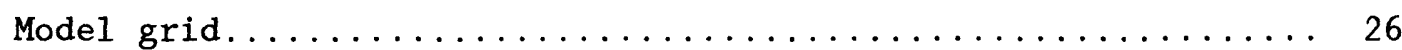

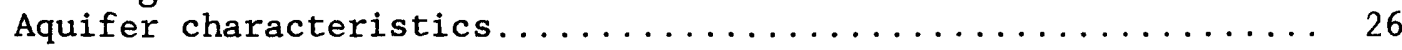

Hydraulic conductivity and transmissivity........... 29

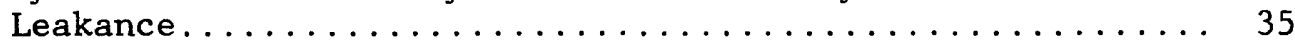

Specific yield and storage coefficients........... 36

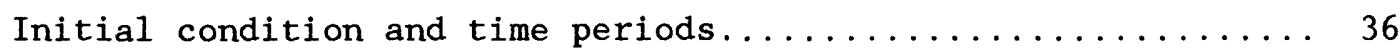

Boundary conditions......................... 37

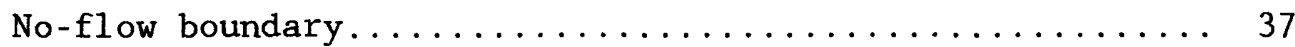

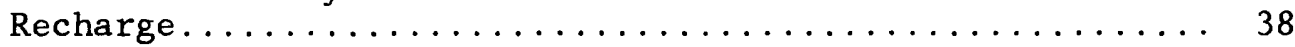

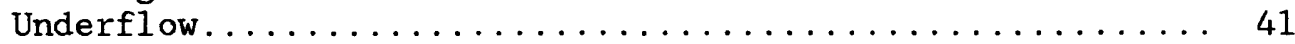

Mesilla Valley boundary..................... 41 
Flow to and from the river and drains......... 41

Evapotranspiration from nonirrigated lands......... 42

Evaporation from streams.................. 42

Net irrigation flux.................... 42

Nonirrigation withdrawals................. 44

Model adjustments........................... 44

System properties used for comparison............... 44

Surface-water depletions.................... 45

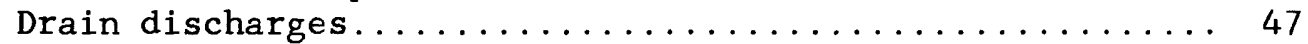

Hydraulic heads........................ 47

System properties adjusted.................... 49

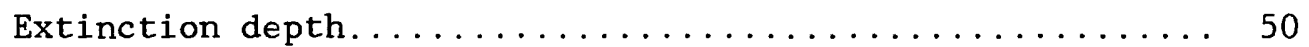

Recharge............................. 50

Specific yield and specific storage............. 50

Model boundary......................... 56

Hydraulic conductivity..................... 56

Effects of existing withdrawals on flow in the Rio Grande........ 57

Model evaluation and sensitivity tests................. 62

Summary and conclusions........................... 64

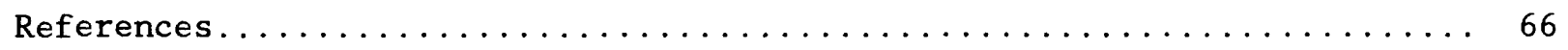

\section{FIGURES}

Figure 1. Map showing location of the study area............. 3

2. Diagram showing system of numbering wells in New Mexico.... 6

3. Diagram showing system of numbering wells in Texas....... 7

4-6. Graphs showing:

4. Average annual and April-to-October precipitation at selected stations in and near the Mesilla Valley...... 9

5. Annual discharge of the Rio Grande at Leasburg and El Paso Narrows, and depletion of Rio Grande discharge....

6. Distribution of hydraulic conductivity with depth for the upper, middle, and lower hydrostratigraphic units

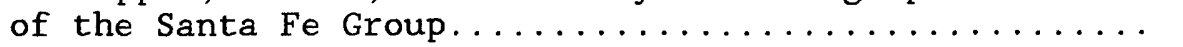




\section{FIGURES--Continued}

Page

Figure 7. Diagram showing interactions between ground water and surface water in the Mesilla Valley................. 17

8. Graph showing estimate of net irrigation flux in the

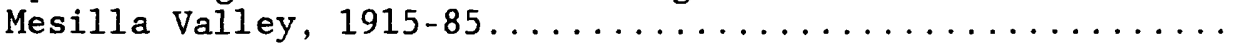

9. Graph showing estimated net ground-water withdrawal rates for nonirrigation uses in the Mesilla valley........... 23

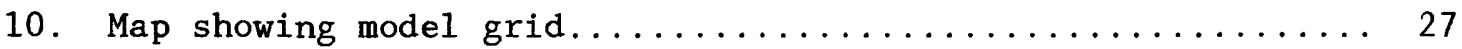

11. Diagrammatic sections along row 22 and column 17 showing layer thicknesses and relation between hydrostratigraphic units and layers............... 28

12-16. Maps showing:

12. Hydraulic conductivity assigned to model layer 1 , the top layer........................ 30

13. Transmissivity assigned to model layer $2 \ldots \ldots \ldots \ldots \ldots$

14. Transmissivity assigned to model layer $3 \ldots \ldots \ldots \ldots \ldots$

15. Transmissivity assigned to model layer $4 \ldots \ldots \ldots \ldots \ldots 33$

16. Recharge, underflow, and evapotranspiration boundaries for layer 1 , steady-state simulation........... 39

17. Graphs showing major basinwide flow rates............ 40

18. Map showing model-derived evapotranspiration from nonirrigated lands for 1975 and area of net irrigation

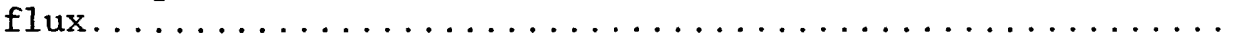

19. Graph showing relation of annual surface-water depletions calculated from measured discharges to depletions calculated from model-derived discharges............. 45

20. Graph showing relation of cumulative surface-water depletions calculated from measured discharges to cumulative depletions calculated from model-derived

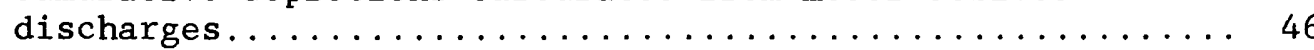

21. Hydrographs showing measured and model-derived drain discharges........................... 48

22. Map showing measured hydraulic heads and model-derived steady-state potentiometric surface, layer $1 \ldots \ldots \ldots \ldots \ldots$ 


\section{FIGURES--Concluded}

Page

Figure 23. Map showing measured hydraulic heads and model-derived potentiometric surface for $1975-76$, layer $1 \ldots \ldots \ldots \ldots \ldots$

24. Map showing measured hydraulic heads and model-derived potentiometric surface for $1984-85$, layer $1 \ldots \ldots \ldots \ldots \ldots$

25. Hydrographs showing measured and model-derived hydraulic

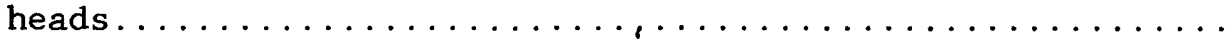

26. Graphs showing effect of changes in diffusivity on the source of water for nonirrigation withdrawals...........

\section{TABLES}

Table 1. Estimated values of hydraulic conductivity of the Santa $\mathrm{Fe}$

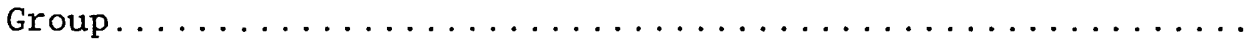

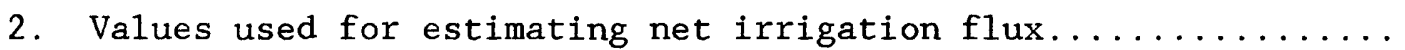

3. Thicknesses of hydrostratigraphic units assigned to each

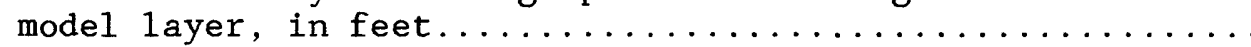

4. Specified inflow to river reaches by stress period......... 136

5. Schedule of nonagricultural ground-water wichdrawal specified in the model...................... 137

6. Differences between measured and model-derived hydraulic

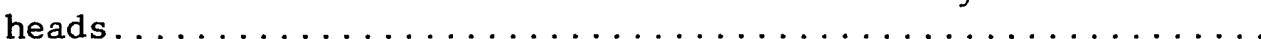

7. Average differences, in feet, between model-derived and measured hydraulic heads for the standard and each sensitivity 


\section{CONVERSION FACTORS AND VERTICAL DATUM}

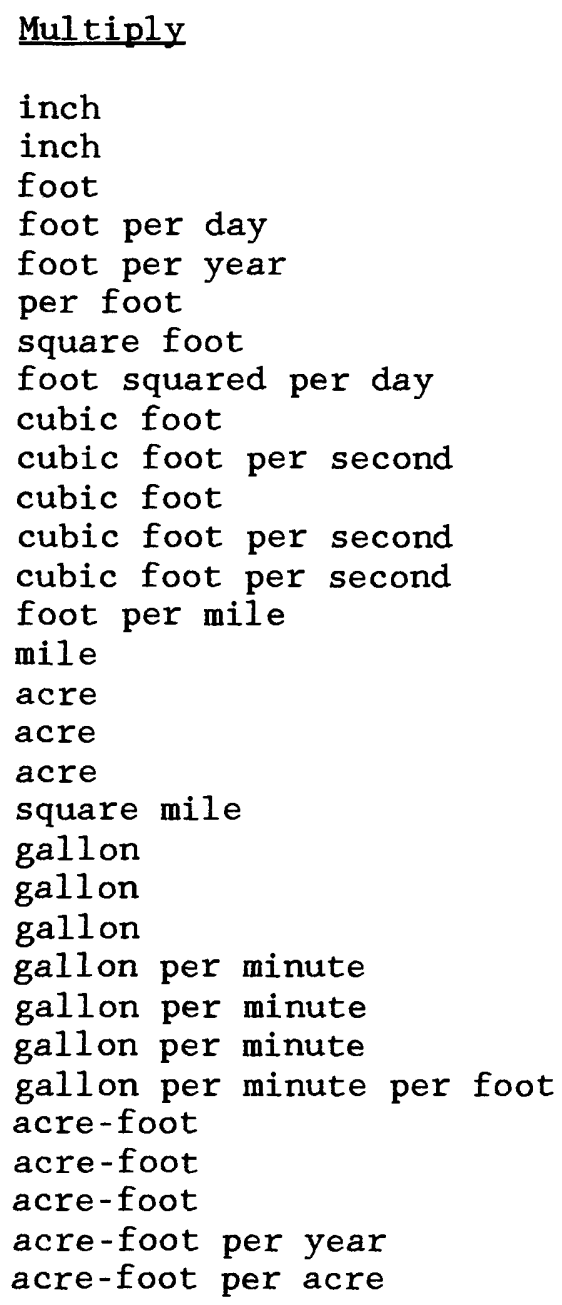

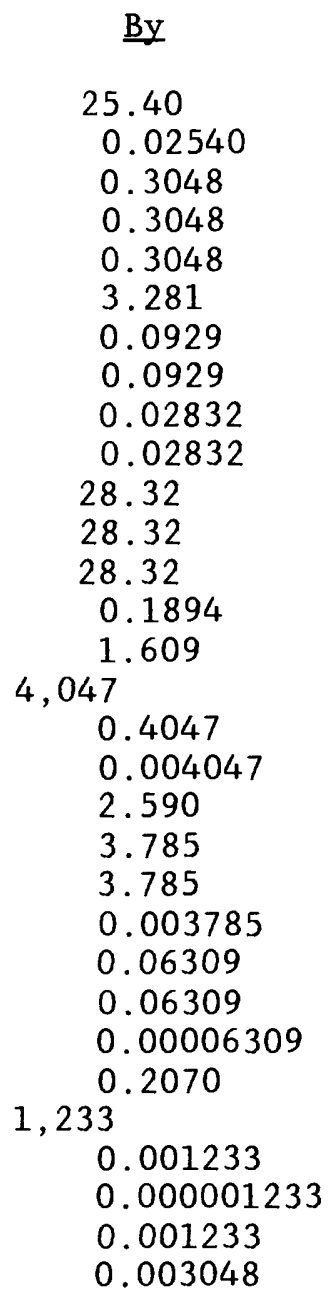

To obtain

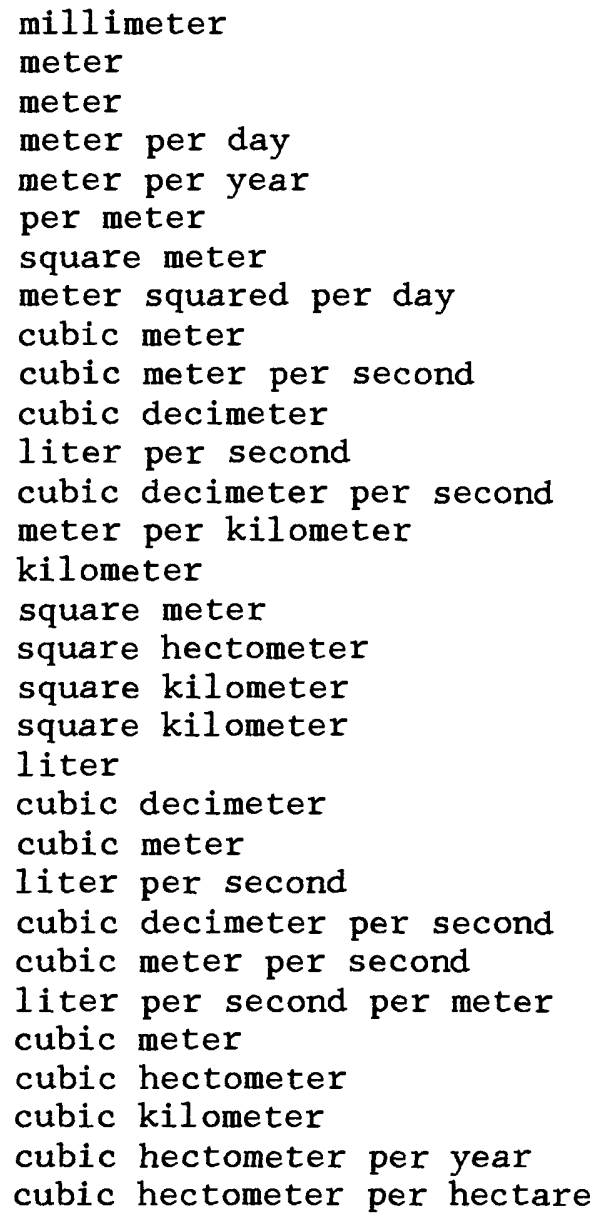

Sea level: In this report, "sea level" refers to the National Geodetic Vertical Datum of 1929--a geodetic datum derived from a general adjustment of the first-order level nets of the United States and Canada, formerly called Sea Level Datum of 1929. 


\title{
SIMULATION OF GROUND-WATER FLOW IN \\ THE MESILLA BASIN, DONA ANA COUNTY, NEW MEXICO, \\ AND EL PASO COUNTY, TEXAS
}

SUPPLEMENT TO OPEN-FILE REPORT 88-305

By Peter F. Frenzel

\begin{abstract}
The Santa $\mathrm{Fe}$ Group of Tertiary age and flood-plain alluvium constitute the major aquifer of the Mesilla Basin. The lateral extent and depth of the ground-water system are defined by bedrock that has much smaller values of hydraulic conductivity than those of the flood-plain alluvium and deposits of the Santa Fe Group. Most flow into and out of the ground-water system occurs at or near land surface in the Mesilla Valley and is the result of a complex interaction of the river, drains, canals, evapotranspiration, and water withdrawals from wells. However, a relatively small amount of recharge results from torrential surface runoff, mainly near the mountain fronts.

Anticipated ground-water withdrawals in the Mesilla Basin may reduce flow in the Rio Grande and thus reduce the quantity of water that is available to downstream users. A previous model (Frenzel, P.F., and Kaehler, C.A., 1990, Geohydrology and simulation of ground-water flow in the Mesilla Basin, Dona Ana County, New Mexico, and El Paso County, Texas, with a section on Water quality and geochemistry by S.K. Anderholm: U.S. Geological Survey Open-File Report 88-305; also to be available as U.S. Geological Survey Professional Paper 1407-C, in press) was revised to assess the effects of existing groundwater withdrawals on flow in the Rio Grande and to provide a tool for the assessment of the effects of future ground-water withdrawals. The revisions included a 10-year extension, from 1975 through 1985, of the original simulation period, a reduction in the simulated thickness of Santa Fe Group deposits based on recent geologic interpretations, and minor changes in simulated recharge and evapotranspiration based on additional data.
\end{abstract}


The revised ground-water model is basically the same as the previous model with some exceptions. The bottom layer (layer 5) was discarded because the basin is now considered to be shallower than was thought previously. Refined estimates of agricultural evapotranspiration averaged 2.4 acre-feet per acre, 0.2 acre-foot per acre per year more than those of Frenzel and Kaehler (1990) as a result of adding estimates of winter evapotranspiration for particular crops. The main difference between this model and the previous model is the way in which transmissivity is estimated. Whereas transmissivity of the previous model was estimated on the basis of depth below land surface and, in a general way, on lithology, transmissivity in this model primarily is estimated on the basis of recent definition of three hydrostratigraphic units of the Santa Fe Group. The current specified hydraulic conductivity of the upper hydrostratigraphic unit of the Santa Fe Group is 30 feet per day. The middle hydrostratigraphic unit of the Santa Fe Group was subdivided on the basis of depth below the water table. The hydraulic conductivity of the middle unit is 20 feet per day ( 10 feet per day at Las Cruces) at depths shallower than 600 feet below the water table and 10 feet per day ( 5 feet per day at Las Cruces) at depths below 600 feet. The hydraulic conductivity of the lower unit is 13 feet per day and the lower unit was absent at Las Cruces.

About two-thirds of the simulated nonirrigation ground-water withdrawals were estimated to be derived from increased depletion of the Rio Grande. About one-sixth was estimated to have been derived from depletion of aquifer storage and about one-sixth derived from salvaged evapotranspiration. These proportions are valid for most of the time since the late 1950's, after which time simulated nonirrigation withdrawals ranged from about 35 cubic feet per second (1958-60) to about 60 cubic feet per second (1980-86). These results were not very sensitive to changing hydraulic diffusivity by a factor of 2.25, but could be very sensitive if a well field were located distant from the Mesilla Valley.

\section{INTRODUCTION}

The Mesilla Basin is located mostly in Doña Ana County, New Mexico, extending into El Paso County, Texas, and the State of Chihuahua, Mexico (fig. 1). The river alluvium and Santa Fe Group deposits of the Mesilla Basin are in direct hydraulic connection with the Rio Grande. Future ground-water withdrawals in the Mesilla Basin may reduce flow in the Rio Grande and thus reduce the quantity of water that is available to make deliveries to downstream users. The ground-water hydrology and geochemistry of the Mesilla Basin in central-southern New Mexico and western Texas had been studied as part of the Southwest Alluvial Basins Regional Aquifer-System Analysis program of the U.S. Geological Survey. That study produced a ground-water flow model of the Mesilla Basin (Frenzel and Kaehler, 1990; also to be available as U.S. Geological Survey Professional Paper 1407-C, in press) that simulated the effects of ground-water withdrawals on flow in the Rio Grande. The U.S. Geological Survey, in cooperation with the International Boundary and Water Commission, conducted the study described here to revise the Frenzel-Kaehler ground-water flow model to reassess the effects of ground-water withdrawals in the Mesilla Basin on flow in the Rio Grande. 

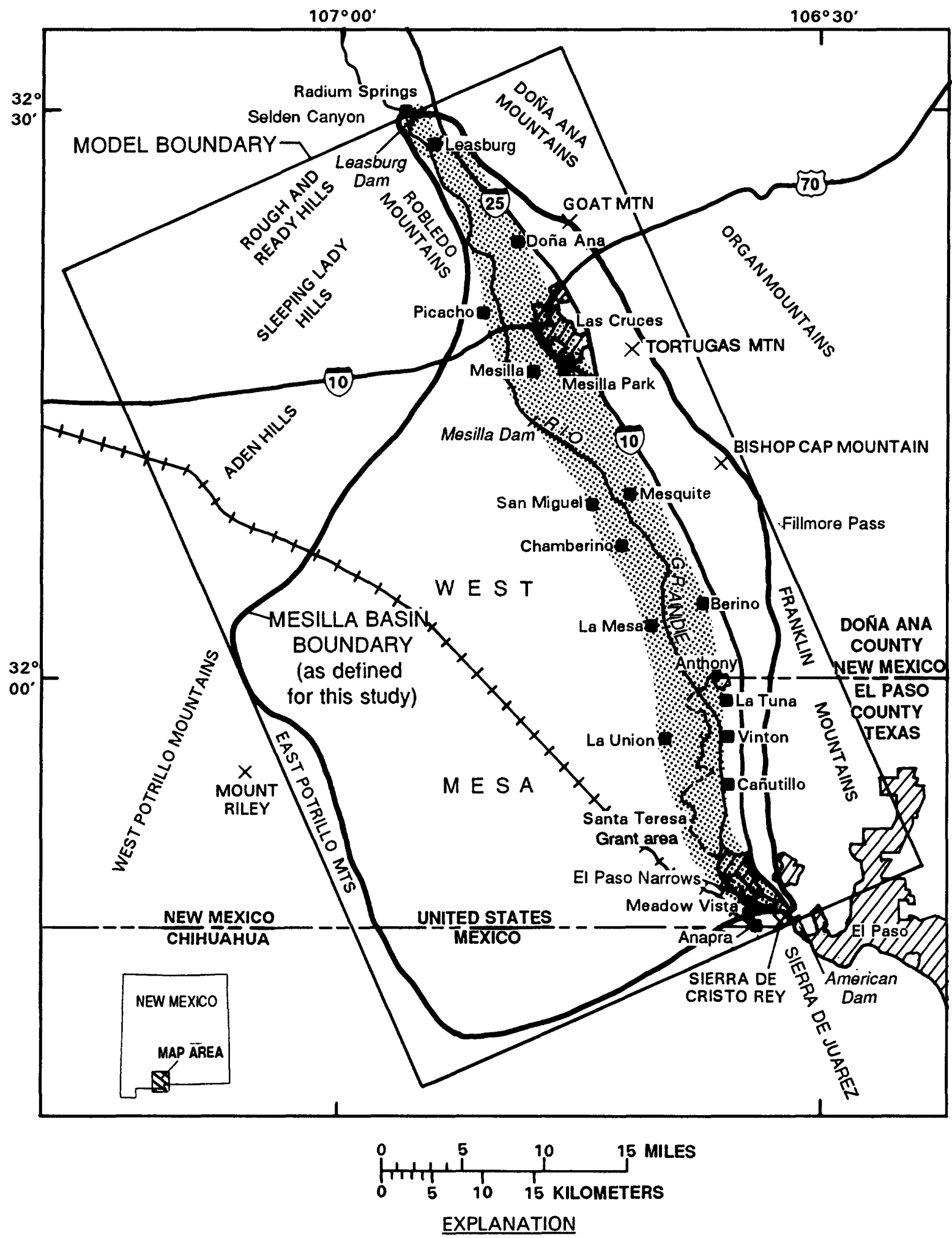

Za approximate extent of major urban areas

EXTENT OF MESILLA VALLEY

Figure 1.--Location of the study area. 


\section{Purpose and Scope}

This report describes the revision of the Frenzel-Kaehler (1990) model and the assessment of the effects of existing ground-water withdrawals on flow in the Rio Grande. A companion report (Frenzel, 1992) 1ists model-input values on magnetic diskette for the revised model.

The revision includes a 10-year extension, from 1975 through 1985, of the original simulated historical period and the modification of the model to reflect recent geological interpretations concerning the depth and stratigraphy of the Santa Fe Group (J.W. Hawley and R.P. Lozinsky, New Mexico Bureau of Mines and Mineral Resources, written commun., 1988). Extension of the simulated period required assembling ground-water-withdrawal and streamflow data and preparing model input for additional stress periods. Modifying the model to reflect recent geological interpretations mainly involved changing the way in which model-layer transmissivity values and vertical-conductance values were derived, and adjusting the simulated thickness of basin fill. Other improvements were minor, such as estimating agricultural evapotranspiration on the basis of reported acreages of individual crops rather than on the basis of an assumed crop-type distribution for the 1950's and 1960's and estimating winter crop evapotranspiration.

As a supplement to the report by Frenzel and Kaehler (1990), this report describes the changes made to the model, and gives the reasons for the changes and the estimates of model input. The general description of the Mesilla Basin, its geohydrology, and water use are an abridged version of Frenzel and Kaehler's (1990) discussion with some additional information. The description of the model in "Simulation of ground-water flow" closely parallels that of Frenzel and Kaehler (1990) and describes in detail the differences between this model and the Frenzel-Kaehler model. In addition, this report describes the estimated effects of existing ground-water withdrawals on flow in the Rio Grande.

\section{Previous Investigations}

Ground-water investigations in the Mesilla Valley began in the early part of the 20th century. Most were reviewed by Frenzel and Kaehler (1990) who presented an overview of the geology and hydrology of the basin and a digital ground-water flow model. A section on geochemistry in the Mesilla Basin by S.K. Anderholm also was included in Frenzel and Kaehler (1990).

Recent works were not reviewed by Frenzel and Kaehler (1990). Wilson and White (1984) presented aquifer-test data for the central Mesilla Valley, and Myers and Orr (1985) presented aquifer-test data for the northern West Mesa area. A report by Hernandez and others (1987) included estimates of municipal water use for 1984. Nickerson (1989) reported aquifer-test data based on stage changes in the Rio Grande. Ground-water flow-model studies include Gates and others (1984) and Peterson and others (1984). J.W. Hawley and R.P. Lozinsky (written commun., 1988) reviewed electric logs, identifying upper, middle, and lower hydrostratigraphic units (informal usage) of the Santa Fe Group, and found that the Mesilla Basin is shallower than was thought previously. As aquifer characteristics are determined for these individual hydrostratigraphic units, Hawley and Lozinsky's conclusions may be of major significance in the estimation of the basinwide effects of ground-water wi thdrawals. 


\section{Well-Numbering Systems}

Wells in New Mexico are identified by a location-number system based on the township-range system of subdividing public lands. The location number consists of a series of digits, separated by periods, corresponding to the township, range, section, and tract within a section (fig. 2). The townships and ranges are numbered according to their location relative to the New Mexico base 1 ine and the New Mexico principal meridian. The smallest division, represented by the third digit of the final number, is a 10-acre tract. If a well has not been located precisely enough to be placed within a particular section or tract, a zero is used for that part of the location number.

Wells in Texas are identified by a number consisting of five parts (fig. 3). The first part is a two-letter prefix used to identify the county. El Paso County is represented by JL, whereas NM signifies wells in New Mexico that have been given a number using the Texas system. The second part of the number is two digits indicating the 1 -degree quadrangle. Each 1 -degree quadrangle is divided into $6471 / 2$-minute quadrangles. This is the third part of the well number. The first digit of the fourth part indicates the 2 $1 / 2$-minute quadrangle and the last two digits comprise a sequence number that identifies the well from others in the same $21 / 2$-minute quadrangle. The Texas wells used in the study also were given a latitude-longitude location number to aid data processing.

\section{Acknowledgments}

Many people contributed to this study. During the data collection phase, personnel of the U.S. Bureau of Reclamation office in El Paso, Texas, provided records of irrigated crop acreages and precipitation. Records of irrigated acreages were also provided by personnel of the Elephant Butte Irrigation District and E1 Paso County Water Improvement District. Personnel of the U.S. Section, International Boundary and Water Commission provided precipitation records and helped find additional records of irrigated crop acreages. Owen Lockwood of New Mexico State University supplied ground-water-withdrawal and well-construction data. City of Las Cruces personnel provided city groundwater withdrawals and return-flow information. Personnel of the Jornada Water Company and the Doña Ana Mutual Domestic Water Consumers Association contributed updated ground-water-withdrawal data. Discussions about the geology of the Mesilla Basin with J.W. Hawley of the New Mexico Institute of Mining and Technology were valuable. 


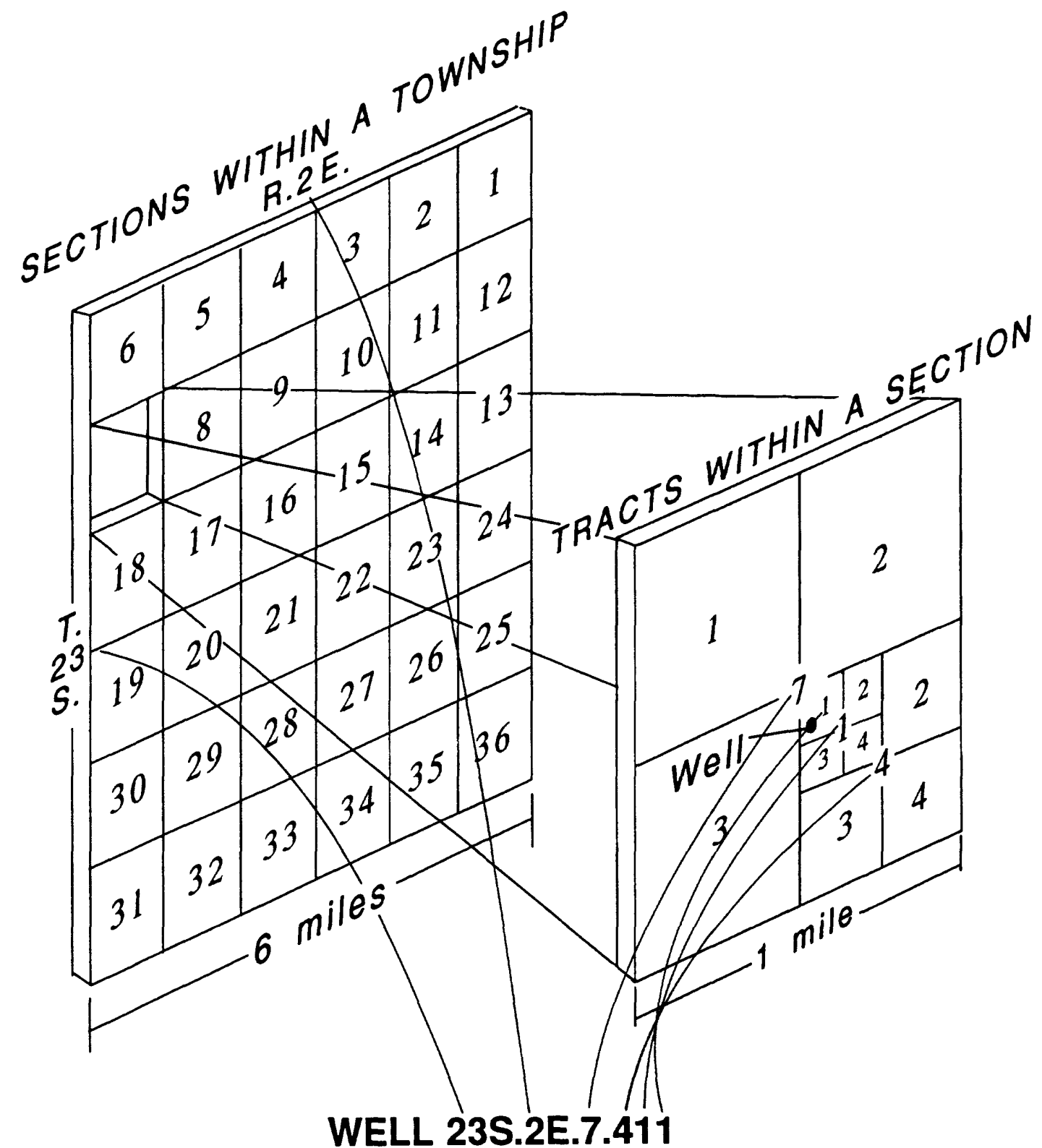

Figure 2.--System of numbering wells in New Mexico. 


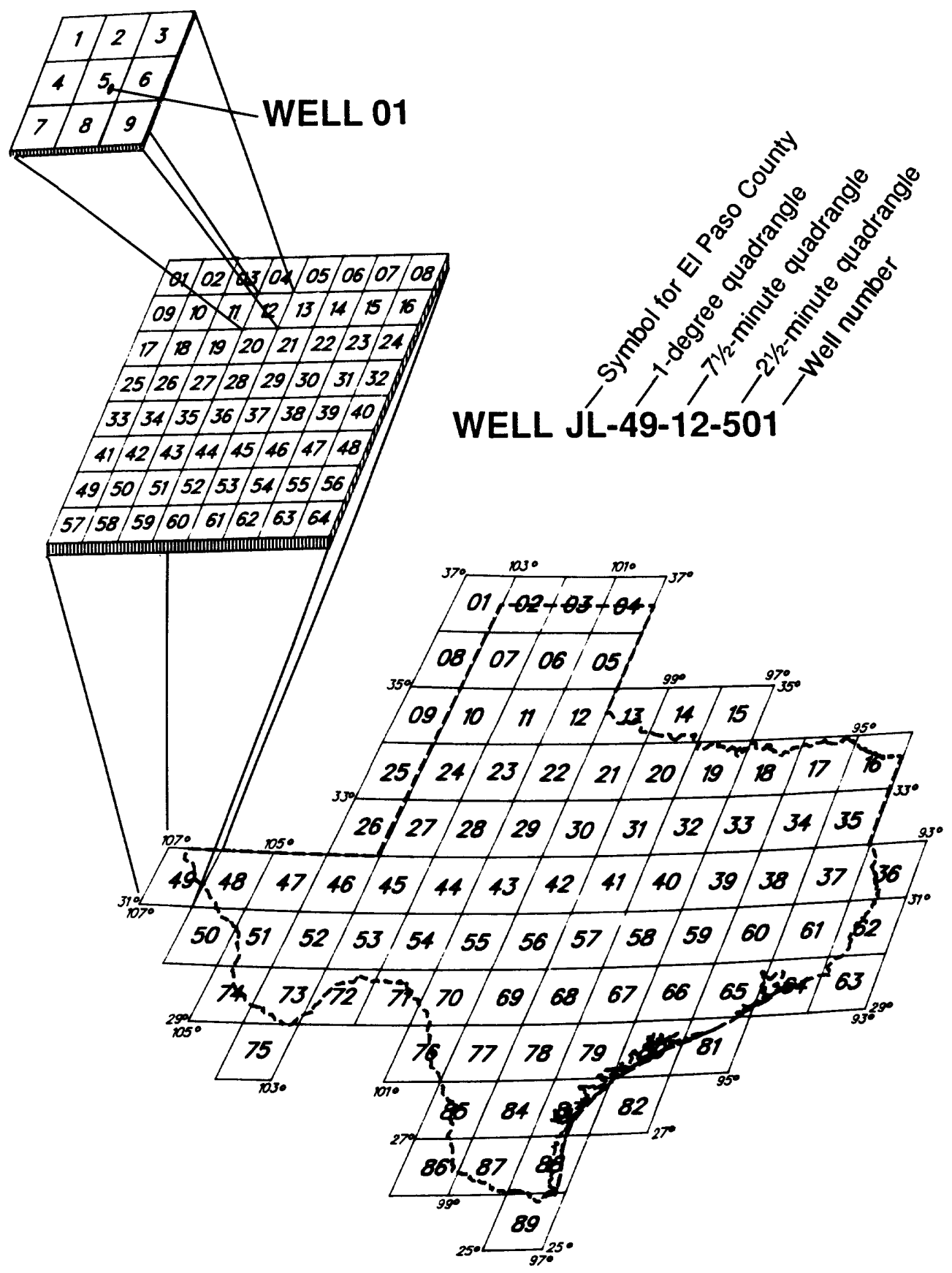

Figure 3.--System of numbering wells in Texas. 


\section{DESCRIPTION OF THE MESILLA BASIN}

The following description is taken from Frenzel and Kaehler (1990). More recent information given in this section generally foreshadows a corresponding change in the updated model. Many of the physical features of the basin are shown in figure 1 .

\section{Physical Features}

The Mesilla Basin is encircled by mountains. The East and West Potrillo Mountains, Aden Hills, and Sleeping Lady Hills are on the west. The Robledo Mountains and Doña Ana Mountains are on the north. Goat Mountain, Tortugas Mountain, the Organ Mountains, Bishop Cap Mountain, and the Franklin Mountains are on the east; on the southeast, the Sierra de Cristo Rey is on the international boundary and the Sierra de Juarez is just south of the International boundary. The highest point in Dona Ana County is in the Organ Mountains $(9,012$ feet above sea leve1), whereas mountains on the west side of the basin have relatively low relief (high point 5,979 feet).

The Rio Grande enters the basin through Selden Canyon between the Ro: do and Doña Ana Mountains and exits through El Paso Narrows between the Franklin Mountains and the Sierra de Cristo Rey. The broad area west of the Rio Grande from the international boundary to the Rough and Ready Hills is called the West Mesa (or La Mesa). The West Mesa is relatively level, has some closed drainage basins, and generally slopes slightly toward the southeast. The area contains scattered extinct volcanoes and an extensive area of lava flows. Incision of the Rio Grande into the mesa surface by as much as 400 feet has formed the Mesilla Valley, which is more than 50 miles long and as much as 5 miles wide. The total area of the Mesilla Valley is about 110,000 acres. The altitude of the Mesilla Valley ranges from 3,980 feet at Leasburg Dam to 3,729 feet at E1 Paso Narrows. East of the Mesilla Valley, the land slopes upward toward the Organ and Franklin Mountains (Frenzel and Kaehler, 1990, p. 9).

The basin, as defined for this report (fig. 1) is not a surface-water drainage area but is

* * * bounded by uplifted blocks of bedrock or by relatively impermeable volcanic rocks and is filled with alluvial sediment from the surrounding mountains and with fluvial sediment carried in by an ancestral Rio Grande. The area between the basin and the mountains generally is covered by similar but relatively thinner sediments. $* * *$ Gravity anomalies and bedrock outcrops indicate that the basin extends about 7 miles into Mexico. However, no hydrologic data were available for that area (Frenzel and Kaehler, 1990, p. 9). 


\section{Climate}

The climate is dry. Pan evaporation averages about 94 inches per year. The average annual precipitation is about 8 inches. Average annual and Aprilto-October (growing season) precipitation is shown in figure 4 . The precipitation values shown in figure 4 were calculated as the mean of values reported for several sites. In addition to the stations at Las Cruces and La Tuna, which were used by Frenzel and Kaehler (1990), nine stations scattered throughout the Mesilla Valley operated since 1975 by the U.S. Bureau of Reclamation were used as well as a station at American Dam operated since 1938 by the U.S. Section of the International Boundary and Water Commission. The Bureau of Reclamation stations are located at Leasburg; Picacho, about 5 miles northwest of Las Cruces; Las Cruces; San Miguel; Mesquite; Chamberino; Anthony; La Union; and Cañutillo.

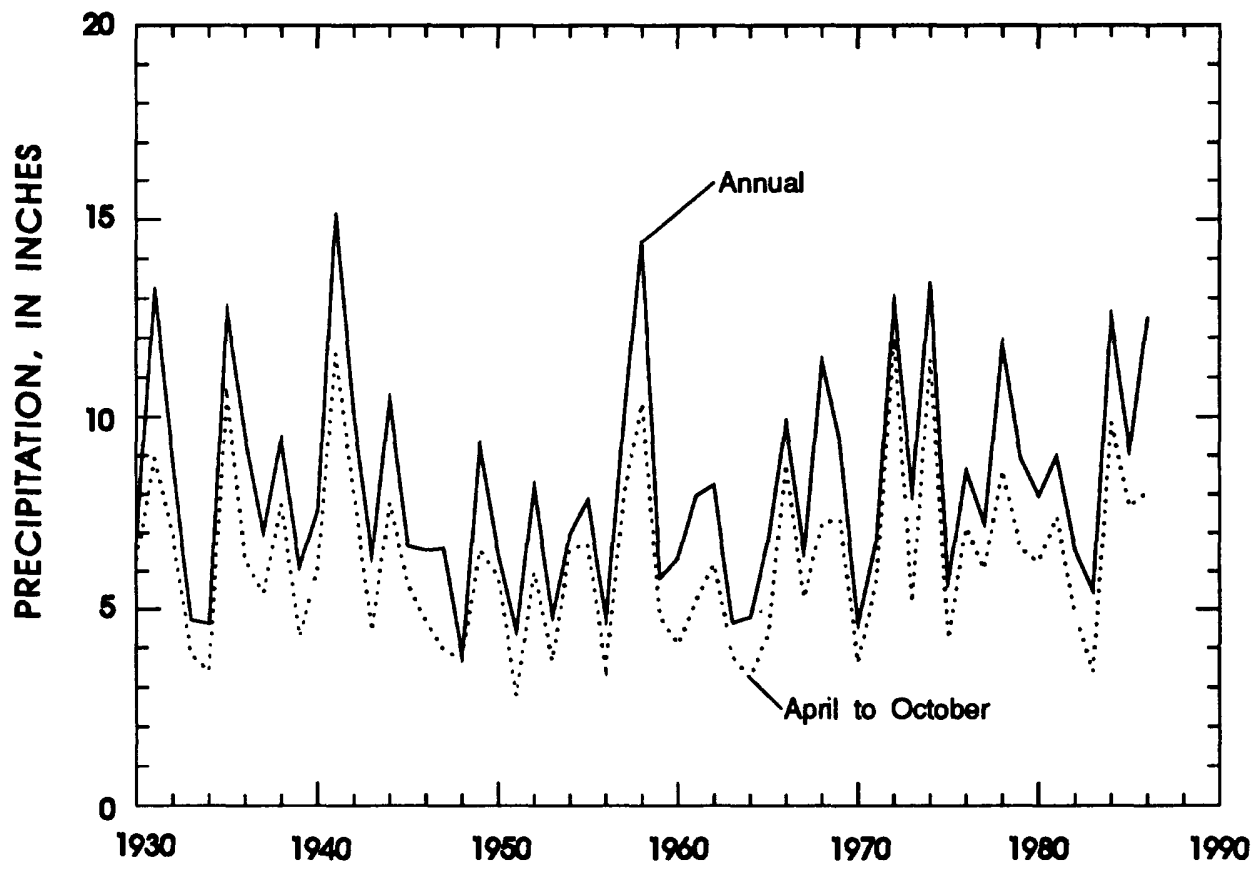

Figure 4.--Average annual and April-to-October precipitation at selected stations in and near the Mesilla Valley. 


\section{Population. Industry, and Agriculture}

Frenzel and Kaehler (1990) discussed the population of the Mesilla Basin and its reliance on ground water.

The main population center within the basin is Las Cruces, which had a population of 8,325 in $1940,29,367$ in 1960 , and 45,086 in 1980 (U.S. Department of Commerce, 1952, p. 31-8; 1982, p. 33). Other population centers in New Mexico include Doña Ana, Mesilla, Mesilla Park, San Miguel, La Mesa, Berino, Chamberino, Anthony, La Union, Meadow Vista, Anapra, and residential developments in the Santa Teresa Grant area $* * *$. New Mexico State University is adjacent to Las Cruces. In the Texas part of the valley are Anthony, Vinton, and Cañutillo. All these communities are dependent upon ground water for domestic and industrial water supply. El Paso, Texas, which had a 1980 population of almost 0.5 million, is mainly southeast of the basin and depends partly on ground water pumped from a well field at Cañtillo. Industry in the area includes produce canneries, an egg-production plant, a steel mill, and a knitting mill.

Agriculture is a major activity, and irrigation is the chief use of water in the Mesilla Basin. The Rio Grande is the primary source of irrigation water $* * *$. Surface water is supplemented by ground water. As of February 1948, there were about 70 irrigation wells in the Rincon and Mesilla Valleys (Conover, 1954, p. 107). During the drought of 1951-57, several hundred wells were drilled in the Mesilla Valley. Many wells were also drilled during a shortage of surface water from 1963 to 1966. As of 1975 there were about 920 usable irrigation wells in the Mesilla Valley (C.A. Wilson, U.S. Geological Survey, oral commun., 1979). The irrigation wells, mostly about 100 feet deep, primarily were completed in the floodplain alluvial aquifer. However, after 1975, a large number of irrigation wells were drilled deeper in order to obtain water of better quality then that available from shallow wells (Wilson and White, 1984), *** Major cxops $* * *$ are cotton, pecans, alfalfa, cereal grains, and vegetabies $* * *$. The number of irrigated acres in Mesilla Valley has increased from about 25,000 acres near the turn of the century to about 77,000 acres during 1940-75*** which is about two-thirds of the area of the valley. Much of the West Mesa area is used for grazing, where there are scattered stock and domestic wells.

Historical irrigation practices have effectively used the ground-water system as a reservoir in a combined stream-aquifer system. During years of plentiful surface water, most irrigation water is diverted from the Rio Grande. About one-third of applied irrigation water may replenish the ground-water system (Blaney and Hanson, 1965, p. 28). Some ground water seeps into drains that discharge to the Rio Grande. During years of inadequate surfacewater supply, the shortfall is made up from ground water, causing lower than usual ground-water levels and diminished drain discharge. Ground-water levels generally return to normal after an irrigation season when surface water is plentiful (Frenzel and Kaehler, 1990, p. 11 and 14). [Withdrawal rates for irrigation wells are unknown.] 


\section{Surface-Water System}

The surface-water system is comprised of the Rio Grande and its tributaries, a distribution system of canals and laterals, and drainage ditches that return water to the Rio Grande (Frenzel and Kaehler, 1990, pl. 1). Flow in the Rio Grande is almost completely controlled by upstream reservoirs. The channel of the Rio Grande is defined by levees in the Mesilla Basin. Several arroyos (ephemeral streams with straight-walled, flat-bottomed channe1s) flow into the Rio Grande mainly from the mountains on the east side of the basin. Flow in some of the large arroyos is blocked by retention dams near Las Cruces and El Paso. Flow in other arroyos reaches the valley, but probably does not contribute much flow directly to the discharge of the Rio Grande. The convergence of surface flow from time to time into arroyos where it can rapidly infiltrate deep into the sand may provide the principal mechanism for natural recharge of ground water. This is the essential mechanism that Frenzel and Kaehler (1990, p. 41-42) termed "mountain-front" or "slope-front" recharge, which are similar except for location. Mountain- and slope-front recharge together may be 15 cubic feet per second, but the error of this estimate may be very large (plus 100 percent or minus 50 percent (Frenzel and Kaehler, 1990, p. 42). Diversions from the Rio Grande in the Mesilla Basin are at Leasburg and Mesilla Dams. The canal system distributes diverted water to agricultural fields and the drain system returns unused water to the Rio Grande. Depletions of the Rio Grande are calculated as the discharge at Leasburg Dam near the north end of the Mesilla Basin minus the discharge at E1 Paso Narrows. For 71 years, 1915-85, annual depletions have averaged 218,000 acre-feet. Annual discharges and depletions for this period are shown in figure 5. Annual discharges and depletions for 1975-85, in acrefeet, are:

\begin{tabular}{llcl}
\hline & \multicolumn{3}{c}{ Discharge } \\
\cline { 2 - 3 } Year & At Leasburg Dam & At E1 Paso Narrows & Depletion \\
\hline & & & \\
1975 & 591,400 & 360,959 & 230,441 \\
1976 & 663,710 & 402,835 & 260,875 \\
1977 & 398,319 & 214,553 & 183,766 \\
1978 & 338,819 & 156,024 & 182,795 \\
1979 & 563,304 & 312,594 & 250,710 \\
& & 353,983 & 277,397 \\
1980 & 631,380 & 333,329 & 241,543 \\
1981 & 574,872 & 326,642 & 272,409 \\
1982 & 599,051 & 331,955 & 267,759 \\
1983 & 599,714 & 359,361 & 271,533 \\
1984 & 630,894 & 359,917 & 285,994 \\
1985 & 645,911 & & \\
\hline
\end{tabular}

\section{Ground-Water System}

The ground-water system is controlled by the basin-fill geology, geologic boundaries, and the interrelation of ground and surface waters (Frenzel and Kaehler, 1990, p. 19). The interrelation of ground and surface waters occurs mainly in the Mesilla Valley and was termed "Mesilla Valley boundary" by Frenzel and Kaehler (1990). The geologic boundaries of the basin are formed 


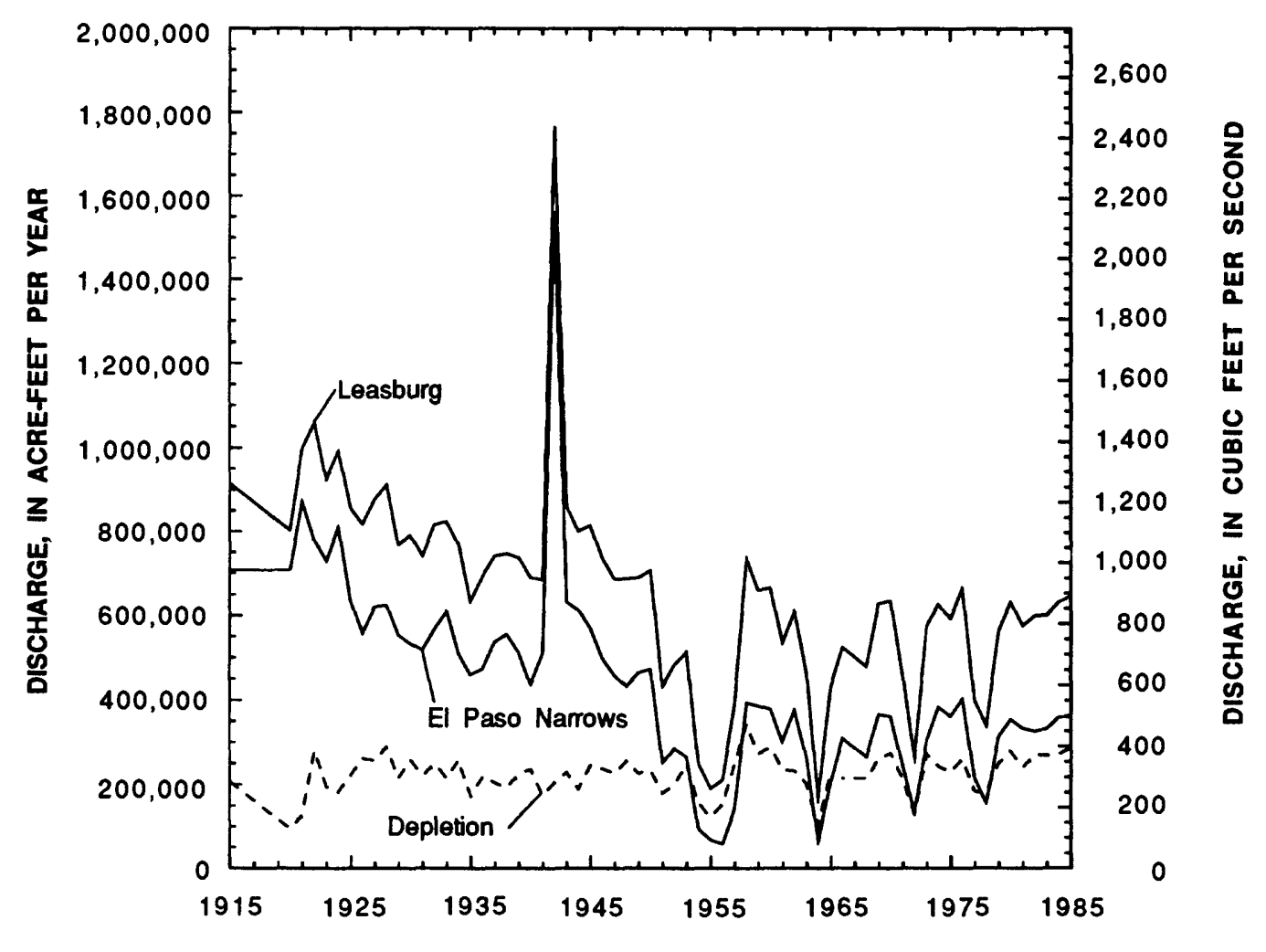

Figure 5.--Annual discharge of the Rio Grande at Leasburg and El Paso Narrows, and depletion of Rio Grande discharge.

by consolidated bedrock units that are generally much less permeable than the basin-fill sediments of the Santa Fe Group and flood-plain alluvium. The Santa Fe Group of Tertiary age and flood-plain alluvium constitute the major aquifer. Frenzel and Kaehler (1990, p. 19-29) described the bedrock, Santa Fe Group, and flood-plain alluvium based on the geologic literature of the late 1970 's and early 1980's.

\section{Hydrogeology of the Basin-fill Deposits}

Since the report of Frenzel and Kaehler (1990), the description of the subsurface geology of the basin has been expanded by Hawley and Lozinsky (written commun., 1988) to include three "hydrostratigraphic" units of the Santa Fe Group. The lower unit is mainly composed of uniform fine sand, whereas the middle and upper units are lenticular and with grain sizes ranging from clay to gravel. The lower hydrostratigraphic unit is about 600 feet thick, ranging from 400 to about 1,000 feet in thickness where it is fully penetrated by wells (Hawley and Lozinsky, written commun., 1988). Because the lower unit is easily distinguishable from the middle unit on electric logs (Hawley and Lozinsky, written commun., 1988), the depth of the base of the Santa Fe Group can be estimated to within a few hundred feet using wells that do not fully penetrate the lower unit. The maximum thickness of the Santa $\mathrm{Fe}$ Group is now considered to be about 2,500 feet, much less than the 3,800 feet that it was previously thought to be (Frenzel and Kaehler, 1990, p. 32). 
The division of the Santa $\mathrm{Fe}$ Group into three hydrostratigraphic units facilitates the assignment of aquifer properties on the basis of stratigraphy instead of strictly on the basis of depth. Although the lower unit consists of more uniform sand, cementation may cause its horizontal hydraulic conductivity to be less than that of the other two units. The middle hydrostratigraphic unit may be somewhat less permeable than the upper unit on the basis of grain size and degree of cementation. The upper hydrostratigraphic unit is saturated mainly in the northern part of the basin and may be the most permeable on the basis of grain size and relative lack of cementation. Horizontal-to-vertical anisotropy is probably greatest in the middle and upper units because of lenticularity (Hawley and Lozinsky, written commun., 1988).

Each estimated hydraulic conductivity in table 1 (tables are in back of the report) was assigned to one of the three hydrostratigraphic units on the basis of the depth tested. The depths of the hydrostratigraphic units at each well site were estimated from plates 16 and 17 of Hawley and Lozinsky (written commun., 1988). Most of the estimated values of hydraulic conductivity in table 1 are from table 1 of Frenzel and Kaehler (1990). Additional values were estimated from values of transmissivity divided by open intervals reported in references given in table 1 .

The relation of hydraulic conductivity with depth that had been apparent in figure 13 of Frenzel and Kaehler (1990) was no longer apparent ( $f$ ig. 6A and $6 \mathrm{C}$ ) for the upper and lower hydrostratigraphic units of the Santa $\mathrm{Fe}$ Group. However, an inverse relation of hydraulic conductivity with depth was still apparent in figure 6B for the middle hydrostratigraphic unit.

For the lower unit, estimated values of hydraulic conductivity given in table 1 range from 1 to 34 feet per day. Of 12 values, the lower quartile is between 2 and 3 , the middle quartile (median) is between 11 and 14 , and the upper quartile is 17 feet per day.

For the middle unit, estimated hydraulic conductivity ranges from 1 to 100 feet per day (table 1). Of 38 values, the lower quartile is 5 , the middle quartile (median) is between 13 and 14, and the upper quartile is 25 feet per day. However, because of the apparent inverse correlation between hydraulic conductivity and depth (fig. 6B), it may be reasonable to divide these data on the basis of depth.

Estimated values of hydraulic conductivity for the middle hydrostratigraphic unit were divided into two groups on the basis of depth below the water table (table 1). Estimated hydraulic conductivity for depths between 600 and 1,210 feet ranges from 1 to 29 feet per day. of 18 values, the lower quartile is 4, the middle quartile (median) is between 8 and 9 , and the upper quartile is 14 feet per day. Estimated hydraulic conductivity for depths shallower than 600 feet ranges from 2 to 100 feet per day. of 20 values, the lower quartile is between 10 and 12 , the middle quartile is 24 , and the upper quartile is between 35 and 36 feet per day.

For the upper unit, estimated hydraulic conductivity ranges from 2 to 68 feet per day (table 1). Of 23 values, the lower quartile is between 10 and 12 , the middle quartile is 25 , and the upper quartile is 47 feet per day. 

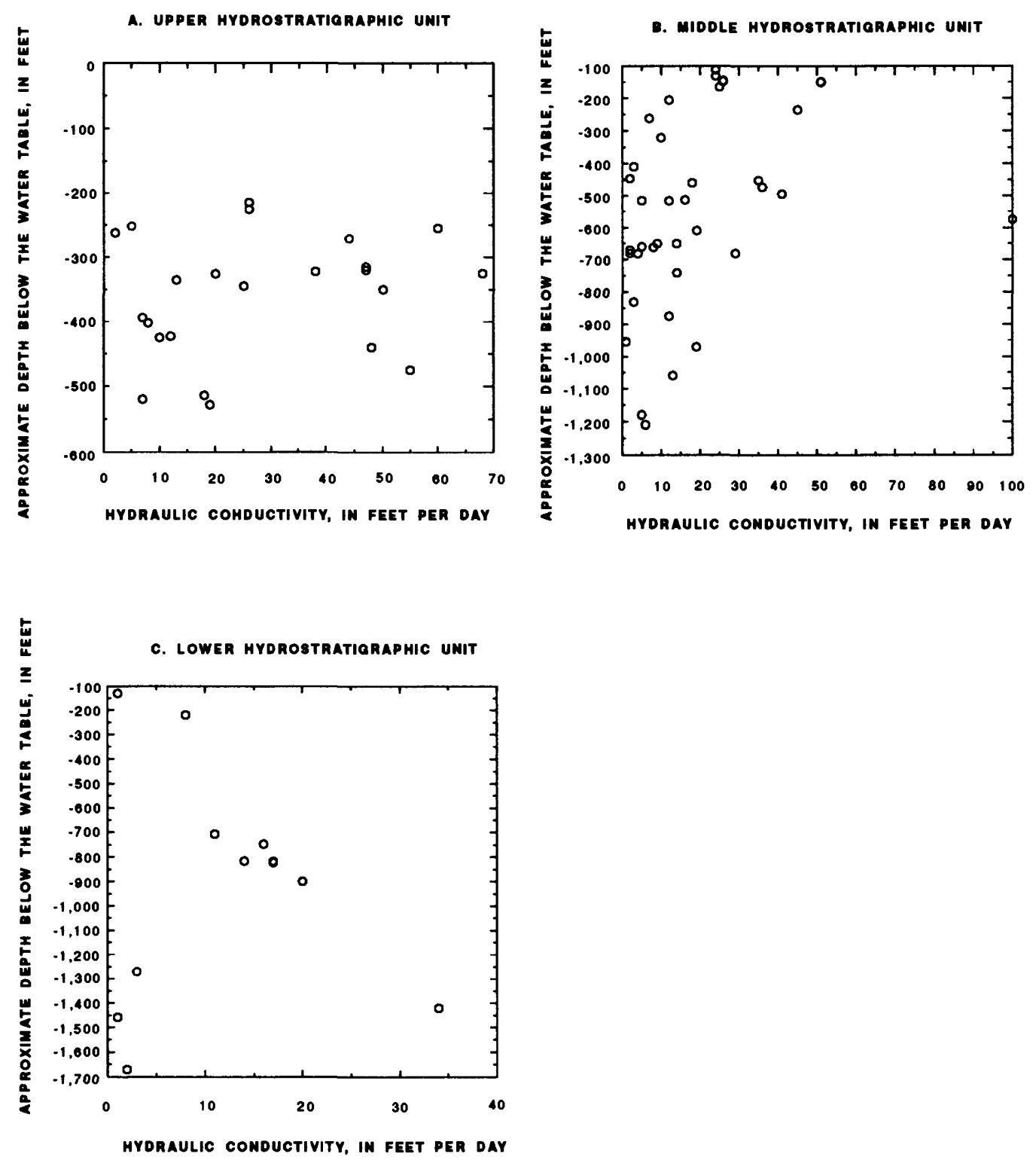

Figure 6.--Distribution of hydraulic conductivity with depth for the upper, middle, and lower hydrostratigraphic units of the Santa Fe Group. 
In the Las Cruces area, faults may cause a reduction in the overall transmissivity of the upper and middle hydrostratigraphic units of the Santa Fe Group. Plate 1 of Hawley (1984) shows many more faults in the Las Cruces area than in other parts of the Mesilla Basin. Faults may cause sand or gravel lenses to be juxtaposed against clay lenses, causing a reduction in transmissivity. Also, fault planes have been observed in the Las Cruces area that were more cemented than the rest of the formation (J.W. Hawley, New Mexico Bureau of Mines and Mineral Resources, oral commun., 1989).

The flood-plain alluvium is about 4 miles wide along the Rio Grande, and is much more permeable than the Santa Fe Group deposits. Wilson and others (1981, pl. 11) reported values of transmissivity of 10,000 to 30,000 feet squared per day for the upper 150 feet of the aquifer, which is composed of about 80 feet of river alluvium overlying about 70 feet of the Santa Fe Group. If the 70-foot thickness of Santa Fe Group deposits is assumed to have a hydraulic conductivity of about 25 feet per day, it then has a transmissivity of 1,750 feet squared per day, and by subtraction, the transmissivity of the river alluvium is between 8,250 and 28,250 feet squared per day. Dividing transmissivity values by the 80 -foot thickness yields hydraulic-conductivity values for the river alluvium ranging from about 100 to 350 feet per day.

Under water-table conditions, specific yield may be about 0.2 as indicated by previous studies (Richardson and others, 1972, p. 86; Lizarraga, 1978 , p. 29; Wilson and others, 1981, fig. 10). Under fully saturated conditions, the specific storage may be about 1 x 10-6 per foot of thickness. This value is common in sedimentary rocks (Lohman, 1972, p. 8) and accounts for expansion of water and some elastic matrix compression.

\section{Hydrogeologic Boundaries}

The Mesilla Basin (fig. 1) is generally surrounded by a pediment-like structure where the bedrock is relatively shallow between the basin and the surrounding mountains (Frenzel and Kaehler, 1990, p. 29-33). In the following discussion the pediment-like structure will be called a "pediment" to signify the general concept even though it is not a true pediment in all locations around the basin. Overlying the pediment are Santa Fe Group deposits. The saturated interval of these deposits is thin relative to the saturated thickness of Santa Fe Group deposits within the basin.

A small quantity of water probably enters the Mesilla Basin around its boundaries. Underflow into the basin from the Santa Fe Group deposits overlying the pediments probably occurs although it is probably small compared to the quantity of water involved in the interaction of ground water with surface water near the axis of the basin (Frenzel and Kaehler, 1990, p. 29). Most mountain-front recharge probably enters the basin as underflow from Santa Fe Group deposits overlying the pediments. A much smaller amount of water may enter the basin from the bedrock surrounding the basin.

A small quantity of water also enters the basin as underflow in the river alluvium near Radium Springs and a similarly small quantity, estimated by Slichter (1905, p. 9-13) to be 0.1 cubic foot per second, leaves the basin in the river alluvium in E1 Paso Narrows. These quantities are small because of the small cross-sectional area of the river alluvium. 
A small, unknown quantity of water probably leaves the basin through Fillmore Pass. The east boundary of the basingenerally is a recharge boundary (Frenzel and Kaehler, 1990, fig. 18) and mountain-front recharge enters the basin largely as underflow along the pediments. Along most of the east boundary, a steep water-table gradient toward the basin exists. Almost no gradient exists between Fillmore Pass and the Mesilla Valley, but a steep gradient does exist toward the east from Fillmore Pass (Wilson and others, 1981 , p1. 9). If no water flowed eastward through Fillmore Pass, some gradient toward the Mesilla Basin from Fillmore Pass might exist because of mountain-front recharge north and south of the pass. Possibly some of the mountain-front recharge in the vicinity of Fillmore Pass flows eastward through the pass and some flows westward toward the Mesilla Basin.

\section{Mesilla Valley Boundary}

Most ground-water recharge and discharge in the Mesilla Basin occurs in the Mesilla Valley. The interaction of ground and surface water is complex in the Mesilla Valley and has been referred to as the "Mesilla Valley boundary" by Frenzel and Kaehler (1990, p. 60). A flow chart for the Mesilla Valley boundary is shown in figure 7 .

The following excerpt taken from Frenzel and Kaehler (1990) describes the relation of ground water and surface water:

The ground and surface waters in the Mesilla Valley are closely interrelated. In addition to mountain- and slope-front recharge, recharge takes place when excess irrigation water percolates through the flood-plain alluvium, as shown by the rise in water levels during the summer irrigation season (Spiegel, 1958). After long periods of heavy pumping, ground-water levels rapidly recover when surface water is applied on agricultural lands (Taylor, 1967).

Ground water is discharged to drains and eventually flows back to the Rio Grande when ground-water levels rise above the drain bottoms. However, during periods of drought, the limited surfacewater supply is supplemented by ground-water withdrawals from wells, and drain discharge is decreased (King and others, 1971, p. 57). Ground water also is discharged by evapotranspiration from crops and natural vegetation in the valley.

A schematic diagram shown in figure 15 [fig. 7 in this report] indicates the following ground-water/surface-water interactions:

(1) A major group made up of (a) net diversions, (b) effective rainfall on both irrigated and nonirrigated lands (effective rainfall is here defined as that part of rainfall that either recharges aquifers or reduces ground-water discharge), (c) evaporation from canal surfaces, and (d) evapotranspiration from irrigated lands, is summed to provide an overall flux for the valley area $* * *$. This summation is termed 'net irrigation flux' in this report, and it includes by implication the leakage from irrigation canals to ground water and that part. of irrigation ground-water pumpage that is not recirculated back to the ground water. 


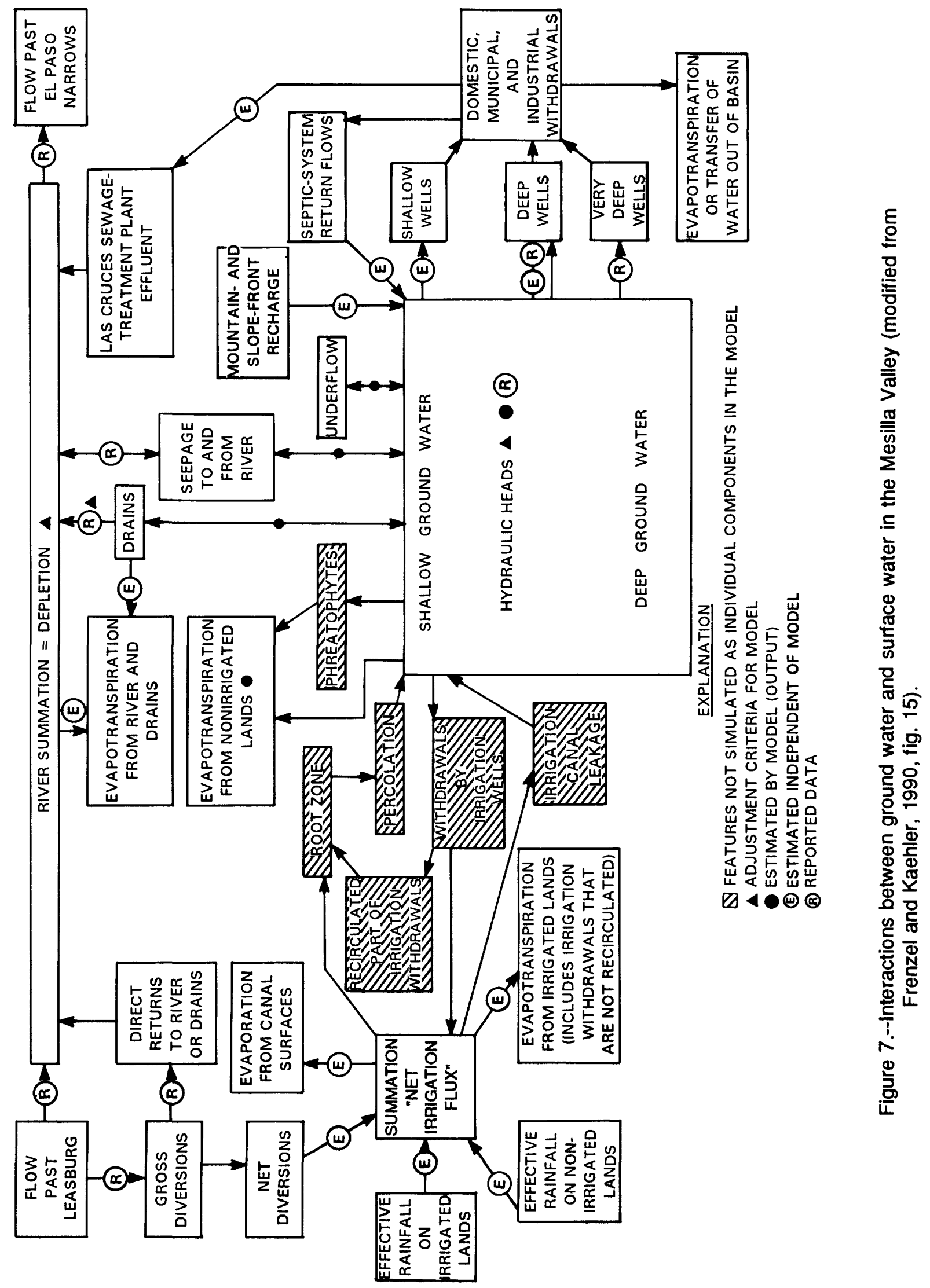


(2) A second major group is comprised of seepage to and from the river and drains. 1ands.

(3) A third major group is evapotranspiration from nonirrigated

(4) A fourth group, of intermediate significance, consists of water pumped from wells for domestic, municipal, and industrial purposes, and septic-system return flows.

(5) Mountain- and slope-front recharge constitutes a relatively minor amount of flow. Most flows have been reported or estimated. Most of the flows to and from ground water occur at or near the land surface in the Mesilla Valley, with the exceptions of discharges from deep wells and mountain-front recharge. These flows fluctuate seasonally, in the short term, but in the intermediate term (1-5 years), they fluctuate with the availability of surface water, and in the long term, they do not fluctuate much at all (Frenzel and Kaehler, 1990, p. 34).

Some of the flow estimates have been revised on the basis of more complete data. Estimates of net irrigation flux were revised on the basis of additional precipitation data and more complete crop acreages. Additional precipitation data were used to revise recharge estimates as well. Timevarying estimates were updated from 1975 through 1985 on the basis of data for those years.

\section{Net irrigation flux}

Net irrigation flux (fig. 8 and table 2) was estimated by essentially the same procedure as used by Frenzel and Kaehler (1990, p. 37) except that the estimates of evapotranspiration and effective precipitation were revised and extended from 1975 through 1985. The net irrigation flux (fig. 8, curve E) was a summation of estimates for annual net diversions ( $f i g .8$, curve A), effective rainfall on irrigated lands (fig. 8, curve B), effective rainfall (ground-water recharge) on nonirrigated lands (fig. 8, curve C), and evapotranspiration from irrigated lands in the Mesilla Valley (fig. 8, curve D). As defined, net irrigation flux implicitly includes all groundwater withdrawals and percolation from irrigated lands. Estimates for these individual components were not made. Estimates of annual net diversions were made for 1976-85 in the same way as estimates for previous years had been made (Frenzel and Kaehler, 1990, p. 37). Estimates of effective rainfall were made in the same way, but were revised slightly on the basis of additional rainfall data and were extended through 1985. Evapotranspiration from irrigated lands for a given year was estimated as a per-acre evapotranspiration rate times the total irrigated acreage of the Mesilla Valley for that year. The per-acre evapotranspiration rate was estimated on the basis of reported annual acreages of individual crop types for each of the years since 1949, whereas Frenzel and Kaehler (1990) based the estimation on an assumed mixture of crops. Also, some irrigated acreage on the east side of the Mesilla Valley that was not accounted for by Frenzel and Kaehler (1990) was included in the estimates. 


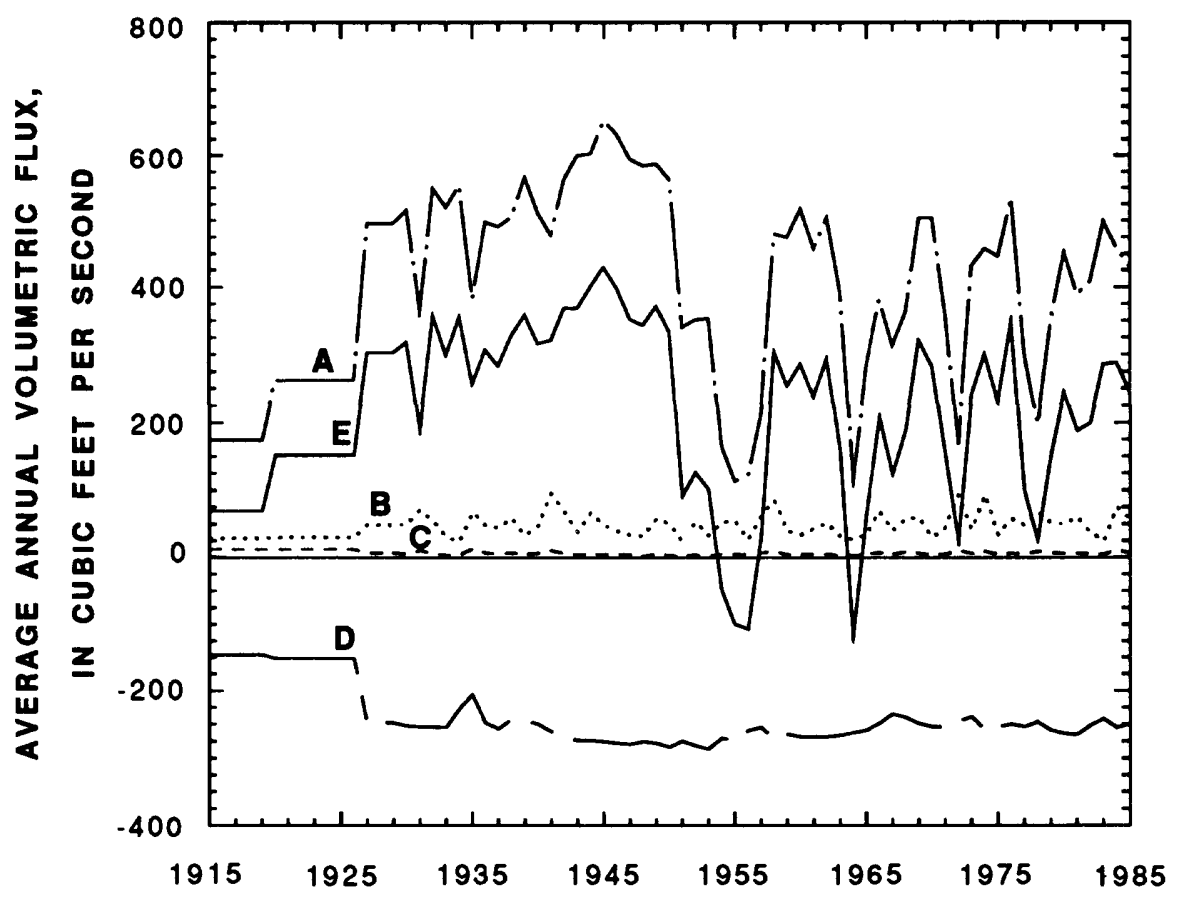

\section{EXPLANATION}

A NET DIVERSION LESS ESTIMATED EVAPORATION

FROM CANALS OF 5.5 CUBIC FEET PER SECOND

B EFFECTIVE PRECIPITATION ON IRRIGATED LANDS

C EFFECTIVE PRECIPITATION ON OTHER LANDS

D ESTIMATED EVAPOTRANSPIRATION FROM IRRIGATED LANDS

E SUMMATION OF A, B, C, AND D, TERMED

"NET IRRIGATION FLUX"

Figure 8.--Estimate of net irrigation flux in the Mesilla Valley, 1915-85. 
In addition to the main part of the Mesilla Valley that is served by a canal system to distribute surface water (Bureau of Reclamation project area) there is a narrow strip of land on the east side of the valley that is irrigated exclusively with ground water. Although records of irrigated acreage outside the Bureau of Reclamation project area generally are not kept, a few estimates have been made from aerial photography. In 1967 , this irrigated acreage was about 2,800 acres (New Mexico State Engineer Office, written commun., 1979); in 1969 it was about 3,200 acres (estimated from data in Lansford and others, 1974, table 16); and in 1983, it was about 3,400 acres. This area may not be significant to the total irrigated acreage; however, the evapotranspiration from this acreage (possibly about 10 cubic feet per second) is significant compared to municipal withdrawals in the Mesilla Basin (about 60 cubic feet per second). Irrigation of this area may have begun in the $1950^{\prime} \mathrm{s}$, when many of the irrigation wells in the Mesilla Valley were drilled. An average of 3,000 acres, beginning in 1958, was assumed (table 2).

Similar to Frenzel and Kaehler (1990), the Blaney-Criddle method was used (Blaney and Hanson, 1965) to estimate annual evapotranspiration rates (acrefeet per acre) for each crop. However, winter transpiration by crops such as alfalfa, pasture, and pecans was accounted for, thereby increasing the estimated evapotranspiration rate. The average annual evapotranspiration rate was about 2.4 acre-feet per acre of irrigated land--an increase of almost 10 percent from that of Frenzel and Kaehler (1990, p. 37), which was 2.2 acrefeet per acre.

An evapotranspiration rate for the Mesilla Valley that reflected the mixture of crop types for the year was estimated for each year since 1949. Acreage information for individual crop types generally is available for most of the Mesilla Valley for years following 1949. For 1953-67 and 1975, acreages of individual crops are reported (Bureau of Reclamation Form 7-316 or equivalent) for the Mesilla Valley part of the Elephant Butte Irrigation District. These reports generally include most but not all of the irrigated acreage in the Mesilla Valley. For 1949-78 and 1980-85, similar reports exist; however, the acreages are for the entire Elephant Butte Irrigation District, combining areas upstream from the Mesilla Valley. The assumption was made that the annually reported individual crop acreages represent the mixture of crops for the entire Mesilla Valley for a given year even though the total of reported individual crop acreages often does not equal the entire irrigated acreage in the Mesilla Valley for the year. The average evapotranspiration rate (table 2) for the valley for a given year was estimated as the sum of evapotranspiration for all reported individual crops divided by the sum of reported individual crop acreages for the year.

The annual evapotranspiration from irrigated land for the entire Mesilla Valley (table 2 and fig. 8, curve D) was estimated as the average evapotranspiration rate times the annual irrigated acreage. Additional details of the estimation of net irrigation flux are given in table 2 . 


\section{Evapotranspiration from nonirrigated lands}

Evapotranspiration from nonirrigated 1 ands was not estimated independently of the model. As explained by Frenzel and Kaehler (1990):

$* * *$ These lands have highly variable hydrologic properties. They include such features as paved roads that may reduce evapotranspiration and collect rainfall, allowing it to infiltrate to the water table in places. Also included are vegetated areas that lie relatively high above the water table, minimizing the availability of ground water to plants, and areas where trees grow near surface water or shallow ground water where evapotranspiration may be near a maximum. Evapotranspiration of ground water from surfaces covered by natural vegetation generally is dependent on the depth to the water table $* * *$.

Seepage to and from streams

Seepage to and from streams, including drains $* * *$ accounts for a major amount of water. The Rio Grande has both gaining and losing reaches that probably change seasonally. The drains gain when ground-water levels are high but may lose in their lower reaches where they join the river or in localities where large amounts of ground water are withdrawn.

The type and amount of interconnection between streams and the aquifer depend on the stream stages and heads in the aquifer and on streambed permeability. Where the water table is below the level of the stream, surface-water recharge to the aquifer can take place; however, the rate of recharge is dependent on the head difference and the permeability of the streambed. The beds of streams that recharge ground water tend to be somewhat more plugged than the beds of streams that receive ground-water discharge because suspended sediment tends to follow the water from the stream into pores of the aquifer, a condition that does not prevail where flow is from the aquifer to the stream.

* * * (Individual drain discharges are shown, for convenience of comparison with model-derived drain discharges, in the section on model adjustment.) The accuracy of drain-discharge measurements probably is poor [accuracy not within 15 percent of the true value] because the stream gradients are low, causing problems with backwater and moss or other vegetation. An additional uncertainty is that drains may receive water from redirected surface water such as excess water from irrigation canals. All drain discharges were assumed to have come from ground water (Frenzel and Kaehler, 1990, p. $38-39$ ). 


\section{Nonirrigation withdrawals and returns}

Reported and estimated ground-water withdrawals for municipal and industrial uses are shown in figure 9. Withdrawals are in four groups: curve $A$ is for wells north of the State line at Anthony excluding the City of Las Cruces, curve B is for wells south of the State line at Anthony excluding the City of El Paso, curve $C$ is for City of Las Cruces wells, and curve D is for City of E1 Paso wells. Curve $E$ is the summation of curves A-D. Groundwater withdrawals before 1976 are the same as those given by Frenzel and Kaehler (1990, p. 39-41, and fig. 17), and values for 1976-85 are reported and estimated as follows. Ground-water withdrawals at the City of Las Cruces are reported values, as are withdrawals at Doña Ana and a group of communities served by Jornada Water Company. Ground-water withdrawals at Mesquite and Anthony, New Mexico, were derived by interpolation between the 1975 estimate of Frenzel and Kaehler (1990, table 4) and values given by Hernandez and others (1987, table 9) for 1984. For these two towns, 1985 values were derived by extrapolation of the 1975-84 values. Ground-water withdrawal-data for wells south of the State 1 ine at Anthony are from the files of the U.S. Geological Survey in E1 Paso (Don White, U.S. Geological Survey, written commun., 1987), including withdrawals at Santa Teresa through 1984. For Santa Teresa, 1985 withdrawals were assumed to be equal to 1984 withdrawals.

Return flows of nonirrigation withdrawals are described by Frenzel and Kaehler (1990, p. 41):

Return flows of municipal, industrial, and domestic water take several forms. Water withdrawn by $E 1$ Paso is not returned in the Mesilla Basin. Slightly more than one-half of the wintertime withdrawals by Las Cruces are returned as surface discharge to the Rio Grande (City personnel, oral commun., 1983). On the basis of data in Sorensen (1977, tables 1 and 2), possibly one-half of the water withdrawn by communities where no surface disposal systems are in use is returned by means of septic systems. Errors in estimates of these return flows probably are not critical because the amount is small.

Sewer-plant effluent from Anthony and La Tuna has been returned to the surface-water system via a nearby drain. Some of the ground-water withdrawals at Santa Teresa supply sprinkler-irrigation systems and some are for municipal use. Sprinkler-irrigation systems may not have a large percentage of return flow, although some return flow is required to avoid a salt buildup in the soil. Disposal of treated municipal wastewater at Santa Teresa is by way of land disposal, a method that probably causes evapotranspiration of a large percentage of the effluent. 


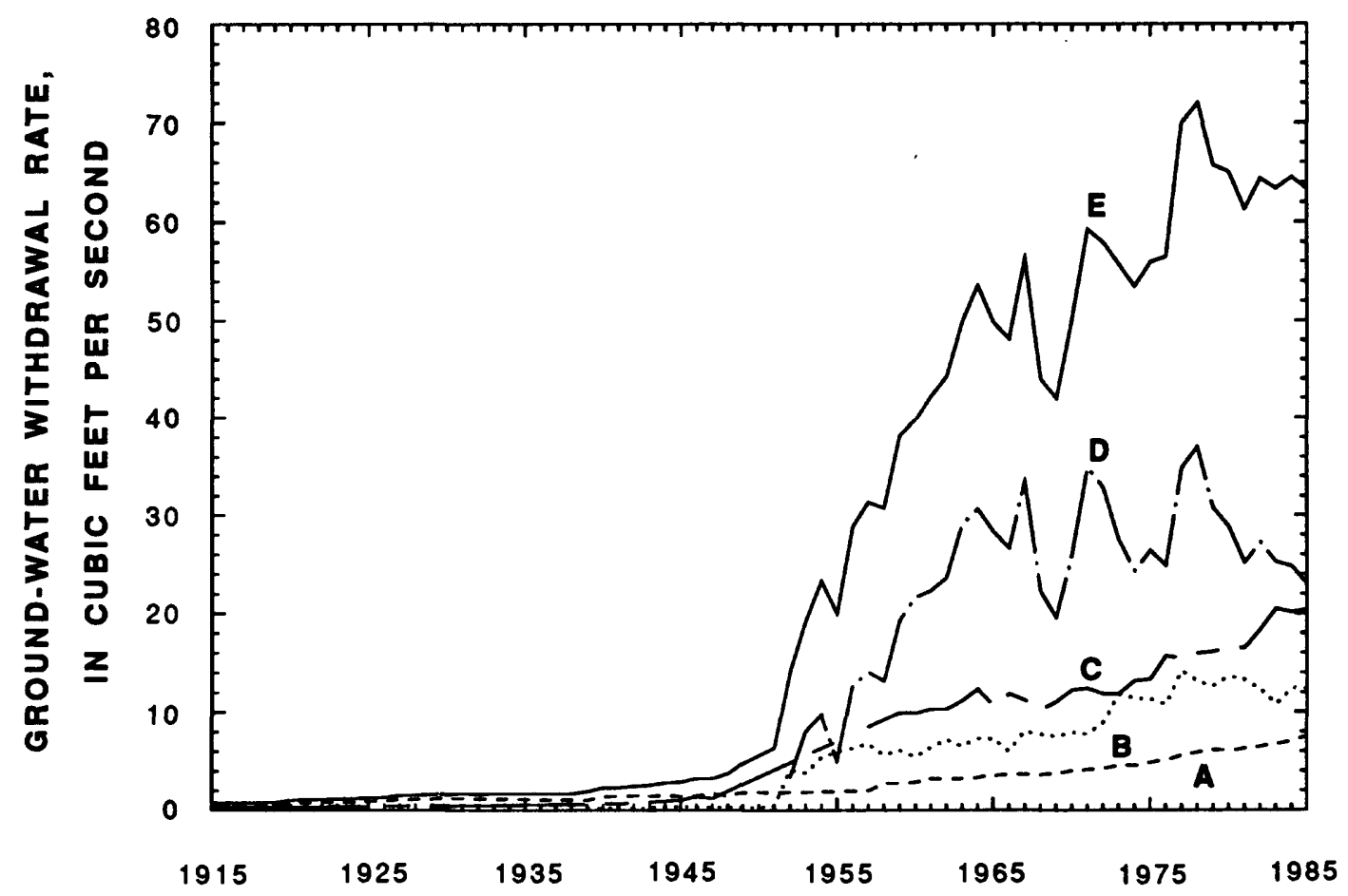

\section{EXPLANATION}

A RATE FOR WELLS NORTH OF THE STATE LINE AT ANTHONY EXCLUDING THE CITY OF LAS CRUCES WELLS

B RATE FOR WELLS SOUTH OF THE STATE LINE AT ANTHONY EXCLUDING THE CITY OF EL PASO WELLS

C RATE FOR CITY OF LAS CRUCES WELLS

D RATE FOR CITY OF EL PASO WELLS

E SUM OF A, B, C, AND D

NOTE: All of the rates shown were estimates of net ground-water withdrawal made exclusively for this study and may be neither complete enough nor appropriate for any other purpose

Figure 9.--Estimated net ground-water withdrawal rates for nonirrigation uses in the Mesilla Valley. 


\section{Mountain- and slope-front recharge}

Recharge to the aquifer probably occurs along ephemeral streams in response to intense, local storms. Beds of ephemeral streams are composed of sand and gravel, and their relatively flat gradients allow for infiltration of water that comes from upstream, relatively steep reaches that are incised in bedrock around the perimeter of the ground-water basin. This recharge is termed mountain-front recharge. Hydrologically similar conditions occur on the sides of the Mesilla Valley where sand channels indicate that rainwater from steep slopes flows into less steep sand channels that do not extend to the river. Recharge under these conditions is termed slope-front recharge. $* * *$ Mountain- and slope-front recharge was estimated $* * *$ by J.D. Dewey (U.S. Geological Survey, written commun., 1983) using an empirical formula developed from a log-multiple regression analysis of measured streamflows. The method has been documented by Hearne and Dewey (1988). *** The total mountain- and slope-front recharge was estimated to be 15.3 cubic feet per second, most recharge occurring on the eastern side of the basin. The potential error in these estimates is great--perhaps plus 100 percent or minus 50 percent. Any recharge on gently sloping areas, such as the West Mesa, probably occurs only occasionally and in small amounts. It is hypothesized that in such areas, where average annual rainfall ( 8 inches) is much less than potential evapotranspiration (50-80 inches), the natural grass and desert shrubs capture all rainfall before it percolates beyond the root zone. *** Recharge on the West Mesa was assumed to be negligible (Frenzel and Kaehler, 1990, p. 41-42).

The effect of using the additional precipitation data in the calculation was to reduce estimated recharge by about 0.1 percent on a long-term average, an insignificant change. Although the inclusion of more data should make estimated annual recharge rates more accurate, the change in annual estimated recharge is probably not significant because short-term variations are damped out by storage in the aquifer.

Summary of Geohydrology

Frenzel and Kaehler (1990, p. 44) summarized the geohydrology of the Mesilla Basin as follows:

* * * (1) The ground-water system is three dimensional: (a) The flood-plain alluvium has a larger hydraulic conductivity than the underlying and laterally contiguous Santa Fe Group; (b) although several water-producing zones have been identified in the southern end of the valley, each with a different hydraulic head, no laterally extensive confining beds have been observed; and 
(c) wells generally do not produce from the full thickness of the aquifer. (2) The lateral extent and depth of the ground-water flow system are defined by bedrock with values of hydraulic conductivity that are much less than those of the Santa Fe Group. (3) Most water that flows into and out of the ground-water system is at or near the land surface in the Mesilla Valley. These flows are the result of complex interactions of the river, drains, canals, evapotranspiration, and withdrawals from wells. These flows fluctuate seasonally, in the short term, but in the intermediate term ( $1-5$ years), they fluctuate with the availability of surface water, and in the long term (more than 5 years), they do not fluctuate much at all. (4) Basinwide withdrawals of water from deep wells (deeper than about 200 feet) before 1975 were small compared to evapotranspiration, but they were locally significant, especially in the Cañutillo and Las Cruces areas. After 1975, withdrawals from deep wells increased because more deep irrigation wells were installed. (5) A small amount of water recharges the ground-water system near mountain fronts. This water comes from surface runoff from the steep mountain drainages. By a similar mechanism, a small amount may recharge the system along the toe of the steeply sloping bluff along the west side of the Mesilla Valley. (6) Recharge of any significant amount over most of the West Mesa area is unlikely, but occasionally may occur in places.

\section{SIMULATION OF GROUND-WATER FLOW}

The ground-water flow model was essentially the same as that of Frenzel and Kaehler (1990) except for the simulated time, which was extended 10 years from 1975 to 1985, and the way in which values of transmissivity and leakance were derived. These items are discussed under the separate headings. Several minor refinements and corrections were made to the Frenzel-Kaehler model. Because it is generally similar and used the same computer program (the U.S. Geological Survey modular model by McDonald and Harbaugh, 1988, with addition of the river-routing package by Miller, 1988), this flow model is most easily described in terms of the similarities and differences between it and the Frenzel-Kaehler (1990) model.

\section{Description of the Mode1}

The model required specification of a three-dimensional grid, aquifer characteristics, time periods, and boundary conditions. Some values were changed during model adjustment. Aquifer characteristics reported in this section are the adjusted values. 


\section{Model Grid}

Except for refinements in the vertical dimension, spacial discretization was the same as that of Frenzel and Kaehler (1990). In the horizontal direction, the grid had 36 rows and 64 columns (fig. 10), and was exactly the same as in Frenzel and Kaehler (1990, fig. 19). In the vertical dimension, layer 5 was discarded because the basin is not as deep as was formerly thought. The thicknesses of layers 1-3 were the same as those of Frenzel and Kaehler (1990) (300, 400, and 600 feet, respectively) except that the thickness of some layers was reduced near the edges of the model to better conform to the shape of the basin. Because the bottom altitude of layer 1 was defined to be 200 feet below the 1975 water table (Frenzel and Kaehler, 1990, p. 47), the saturated thickness of layer 1 was general1y about 200 feet for the calculation of transmissivity. Figure 11 shows diagrammatic sections through the model along row 22 (northwest-southeast) and along column 17 (southwest-northeast). On the left side of figure $11 \mathrm{~A}$, the thickness of layers 1, 2, and 3 has been reduced; on the right side of figure $11 \mathrm{~A}$, thickness of layers 1 and 2 has likewise been reduced. Layers 1, 2, and 3 are not full thickness on the right side of figure 11B. The thickness of layer 4, the bottom layer, was variable throughout its extent. In figure 11, layer 4 varies from about 200 to 1,000 feet. The thickness of 1 ayer 4 was as much as 1,030 feet in the deepest part of the basin.

The layer thicknesses define a mixed grid (McDonald and Harbaugh, 1988, p. 2-29) that is orthogonal throughout most of the model, but deformed near the extremities and at the bottom. Model nodes were located at the center of each model block. Therefore, throughout most of layers 1-3, where model layer thickness was the nominal value, model nodes formed a uniform, orthogonal grid. However, throughout layer 4 and near the extremities of other layers, where they were less than full thickness, model nodes formed a deformed grid. As described below, vertical distances between model nodes were used in the calculation of leakances for each model block. (Leakance is vertical hydraulic conductivity divided by thickness, the term "Vcont" of McDonald and Harbaugh, 1988 , p. 5-11.)

\section{Aquifer Characteristics}

Aquifer characteristics were assigned on the basis of estimated or theoretical values and then adjusted to make the model simulate measured values of hydraulic heads and stream depletions as described in the "Model adjustments" section. Aquifer characteristics are reported in this section as ranges rather than exact values because they tend to vary from block-to-block. Although aquifer characteristics could be approximated from the description given here, exact block-by-block values of aquifer characteristics are available on magnetic diskette in a companion report (Frenzel, 1992). The aquifer characteristics reported here are the most recently assigned (adjusted) values. 

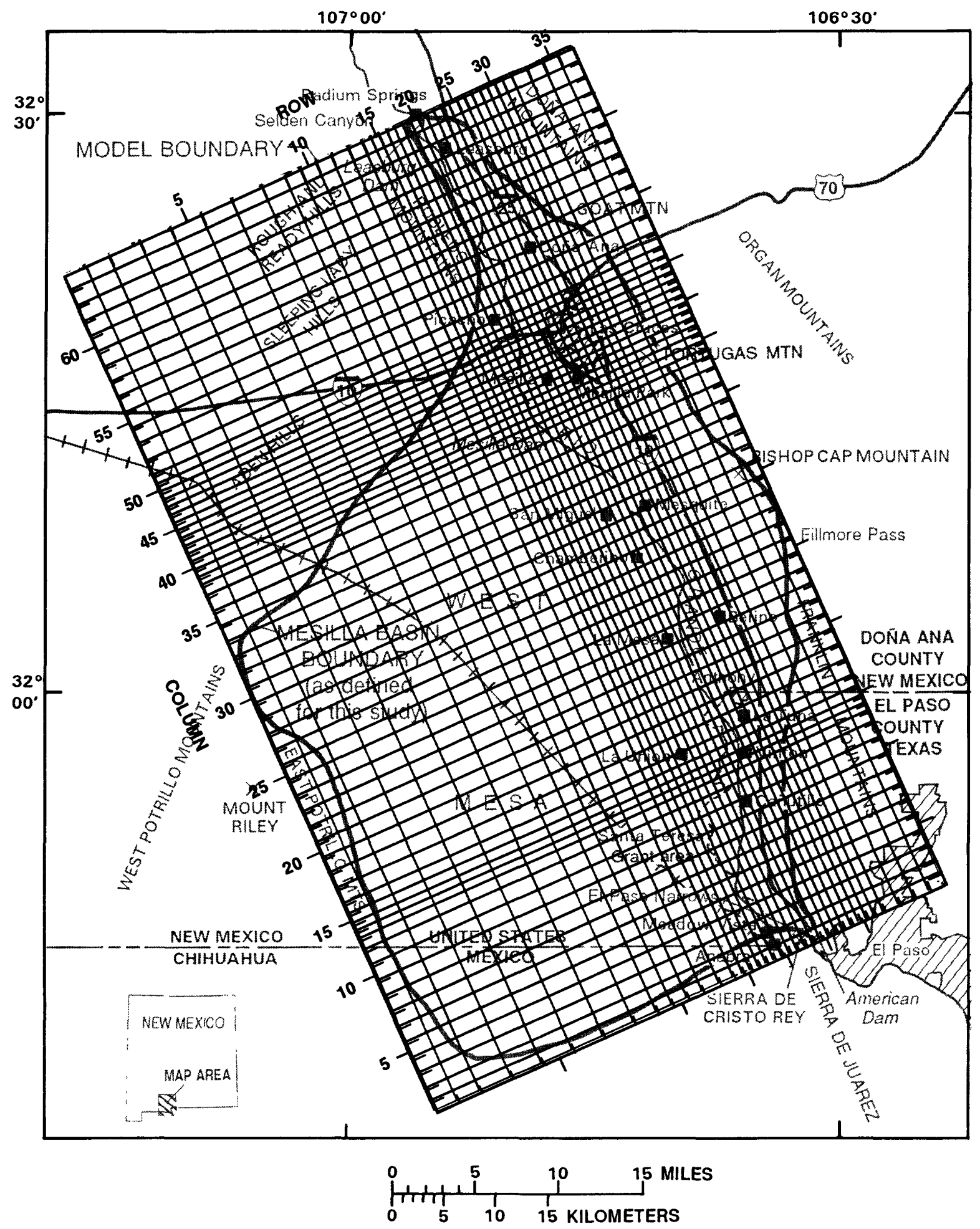

Figure 10.--Model grid. 

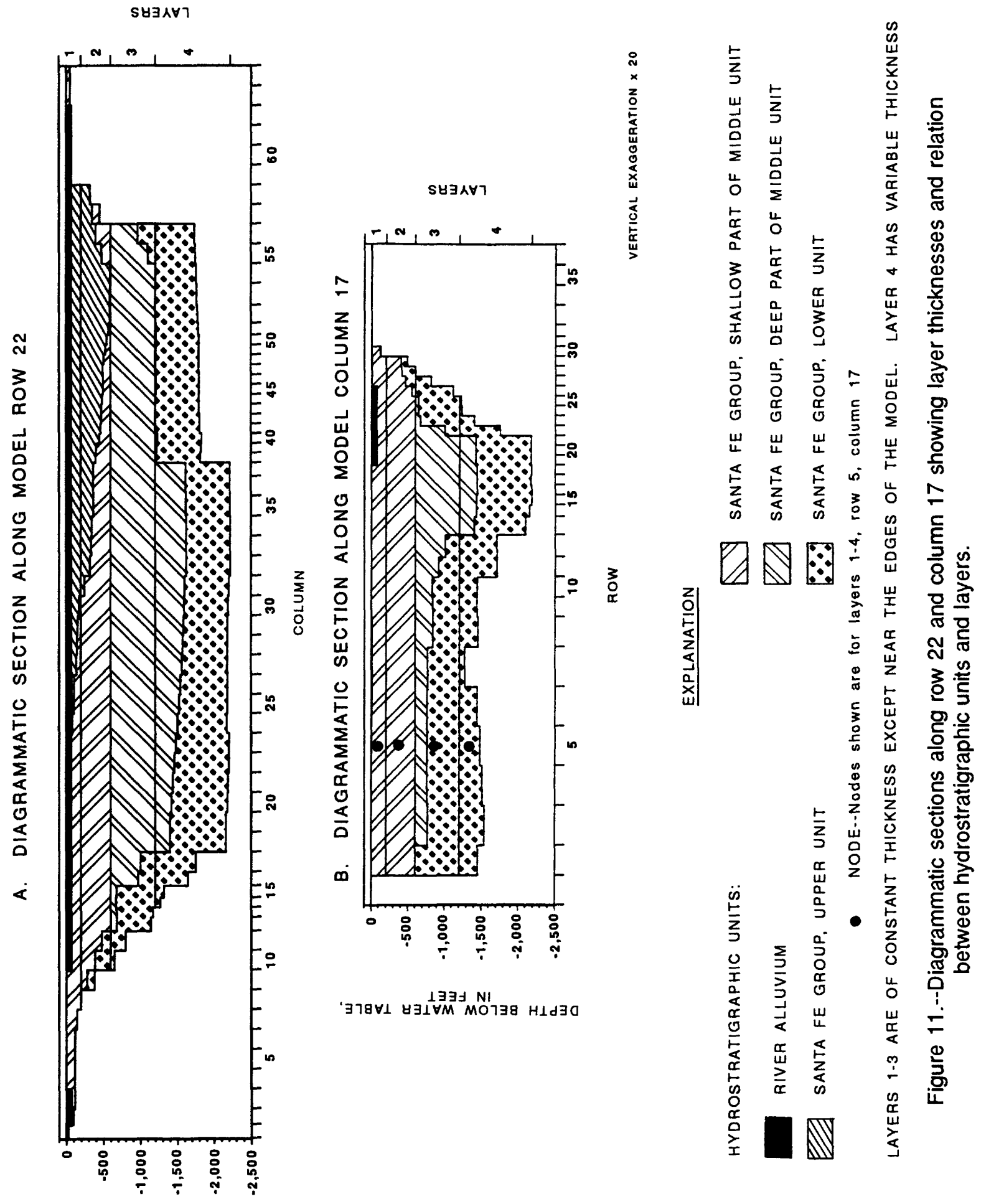

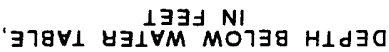


Hydraulic conductivity and transmissivity

Hydraulic conductivity is assigned to layer 1 , from which the model estimates transmissivity on the basis of the saturated thickness (hydraulic head minus the bottom altitude). Layers 2-4 were assigned transmissivity values that were estimated from the hydraulic-conductivity values and thicknesses of hydrostratigraphic units represented in each model block.

The hydraulic conductivity assigned to each block in layer 1 (fig. 12) was a thickness-weighted average for the upper 200 feet of saturated sediments at that block. The hydraulic conductivity (K) assigned to each model block was calculated as:

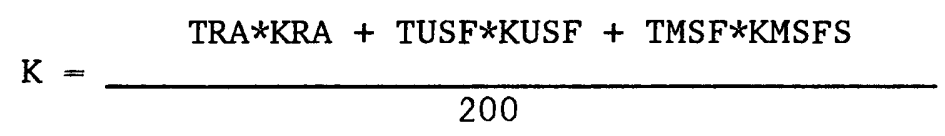

where TRA = the thickness of river alluvium, in feet;

$\mathrm{KRA}=$ the hydraulic conductivity of river alluvium, in feet per second;

TUSF $=$ the thickness of the upper hydrostratigraphic unit of the Santa Fe Group that is within the upper 200 feet of saturated sediments, in feet;

KUSF $=$ the hydraulic conductivity of the upper hydrostratigraphic unit of the Santa Fe Group, in feet per second;

TMSF $=$ the thickness of the middle hydrostratigraphic unit of the Santa Fe Group that is within the upper 200 feet of saturated sediments, in feet; and

KMSFS $=$ the hydraulic conductivity of the shallow part of the middle hydrostratigraphic unit of the Santa Fe Group, in feet per second.

Individual thicknesses may equal zero at any given model block.

The transmissivity values of layers 2, 3, and 4 (figs. 13-15) were calculated in a similar fashion by setting the denominator of equation (1) to unity and substituting the appropriate thicknesses and hydraulic-conductivity values of the hydrostratigraphic units represented. The thicknesses of each hydrostratigraphic unit of the Santa Fe Group and the river alluvium represented by each model layer are given in table 3 . The river alluvium is entirely in layer 1 (fig. 11). In row 22 (fig. 11A), the upper Santa Fe Group hydrostratigraphic unit traverses layer 1 and comprises part of layer 2, the middle Santa $\mathrm{Fe}$ Group hydrostratigraphic unit traverses 1ayers $1-3$ and comprises part of 1 ayer 4, and the lower Santa Fe Group hydrostratigraphic unit comprises parts of layers 2-4. Figure 11B shows a similar pattern along model column 17 . 

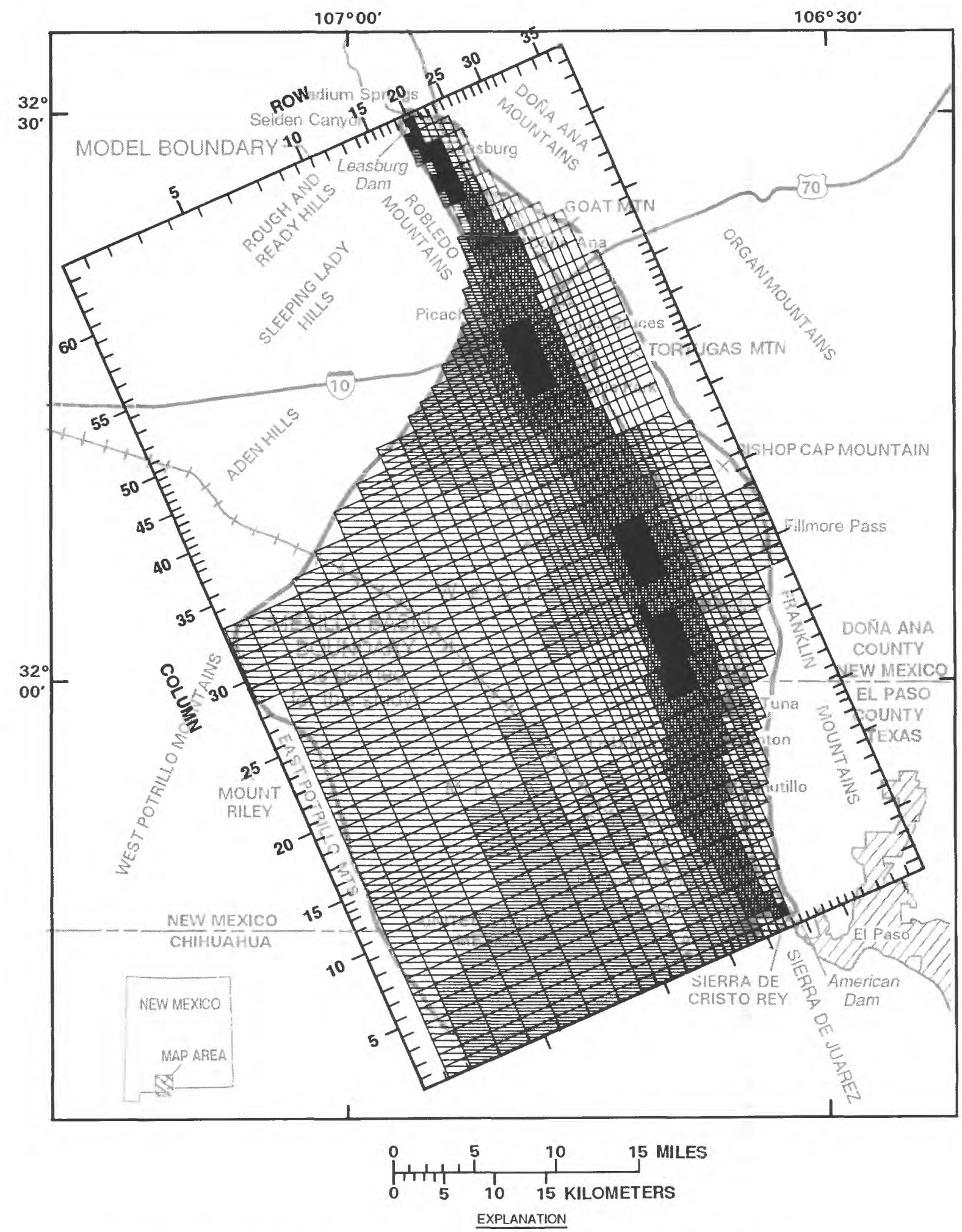

HYDRAULIC CONDUCTIVITY, IN FEET PER DAY:

GREATER THAN 20 AND LESS THAN 30

$\square$ LESS THAN 20

FQual TO OR GREATER THAN 30 AND LESS THAN 120

20 EQUAL TO OR GREATER THAN 120 AND LESS THAN 150

Figure 12.--Hydraulic conductivity assigned to model layer 1, the top layer. 

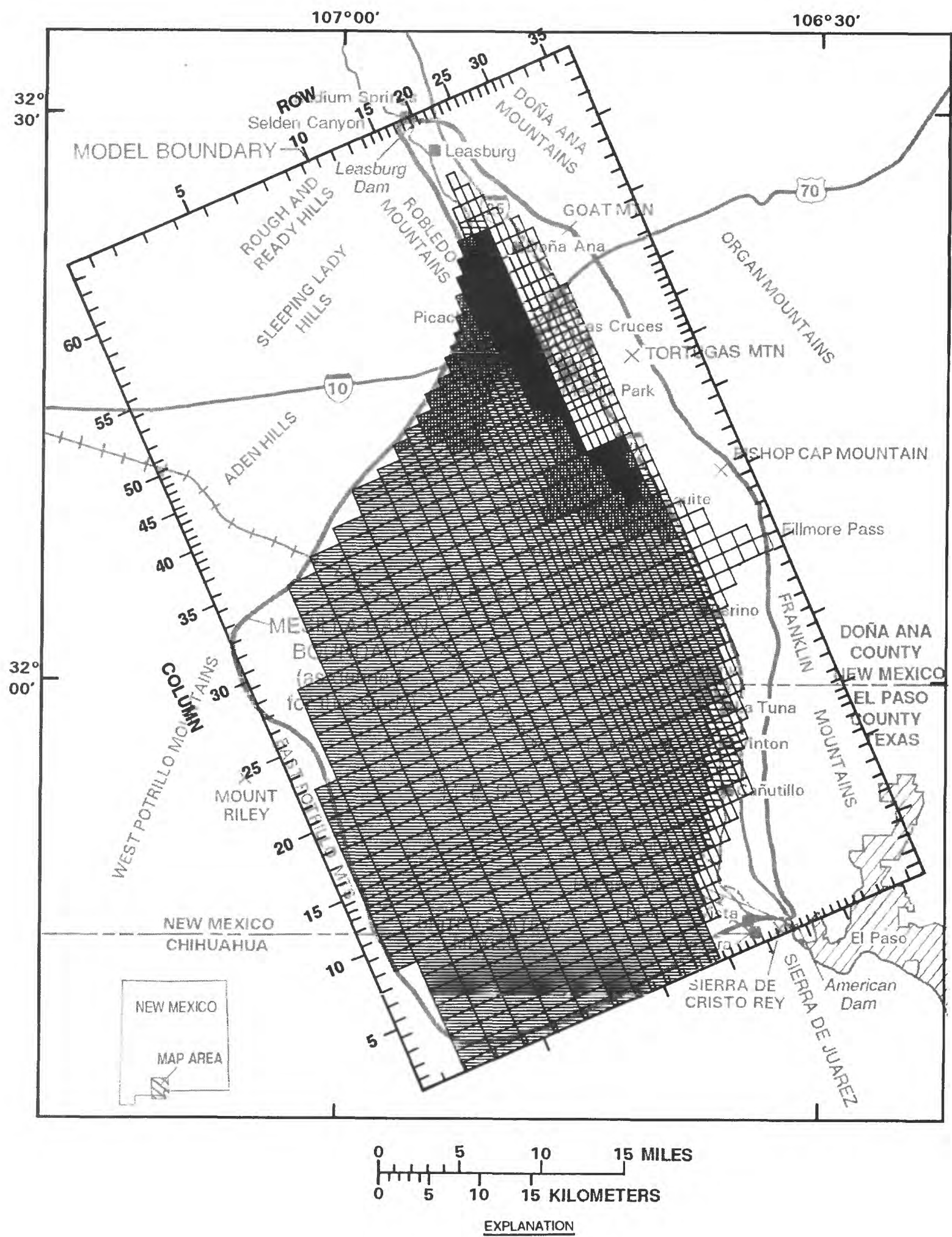

TRANSMISSIVITY, IN FEET SQUARED PER DAY:

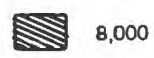

LESS THAN 5,200

EQUAL TO OR GREATER THAN 5,200 AND LESS THAN 7,900

GREATER THAN 8,000 AND LESS THAN 10,000

EQUAL TO OR GREATER THAN 10,000 AND LESS THAN 12,000

Figure 13.--Transmissivity assigned to model layer 2. 


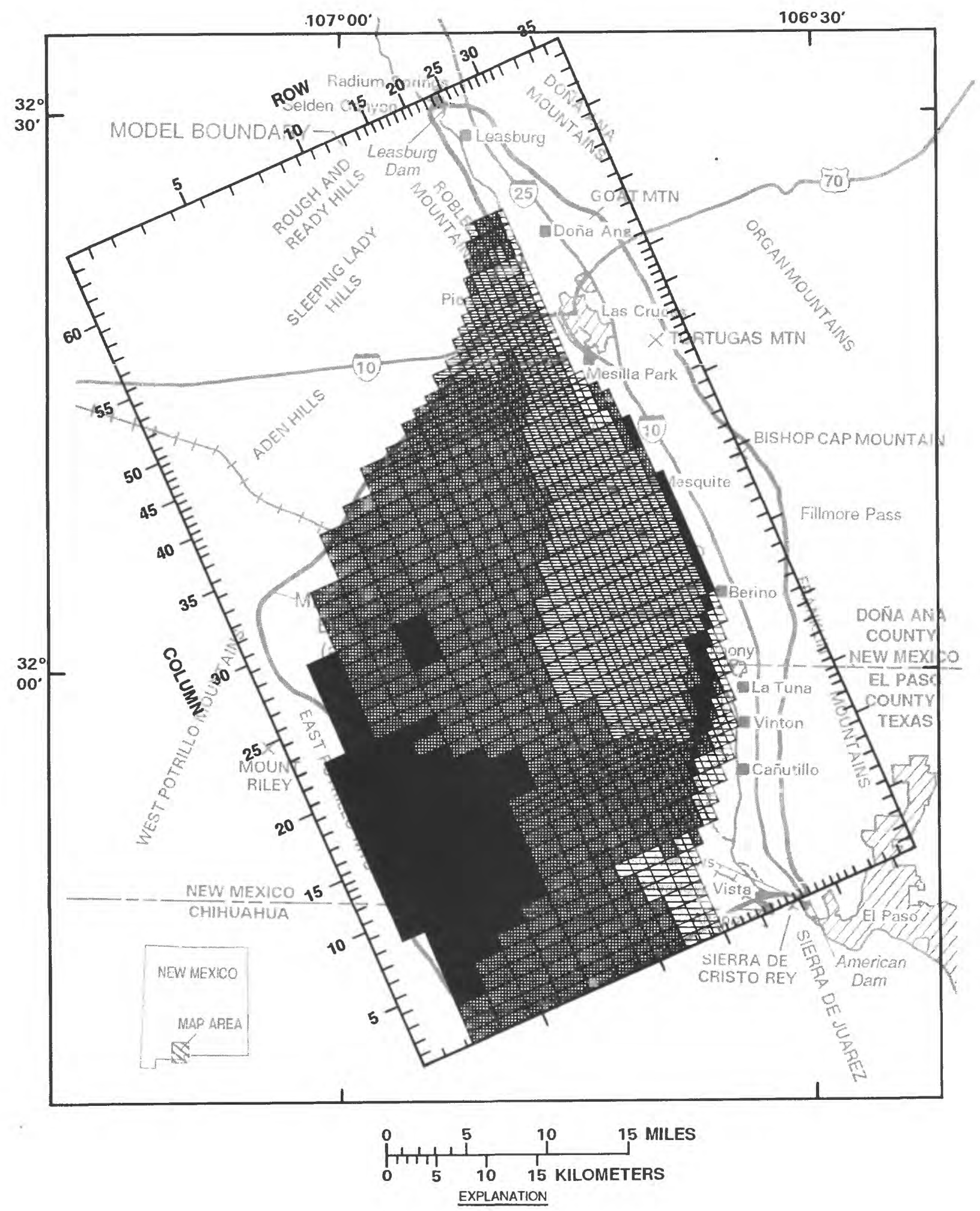

TRANSMISSIVITY, IN FEET SQUARED PER DAY:

LESS THAN 6,000

6,000
GREATER THAN 6,000 AND LESS THAN 7,200

EQUAL TO OR GREATER THAN 7,200 AND LESS THAN 8,400

Figure 14.--Transmissivity assigned to model layer 3. 

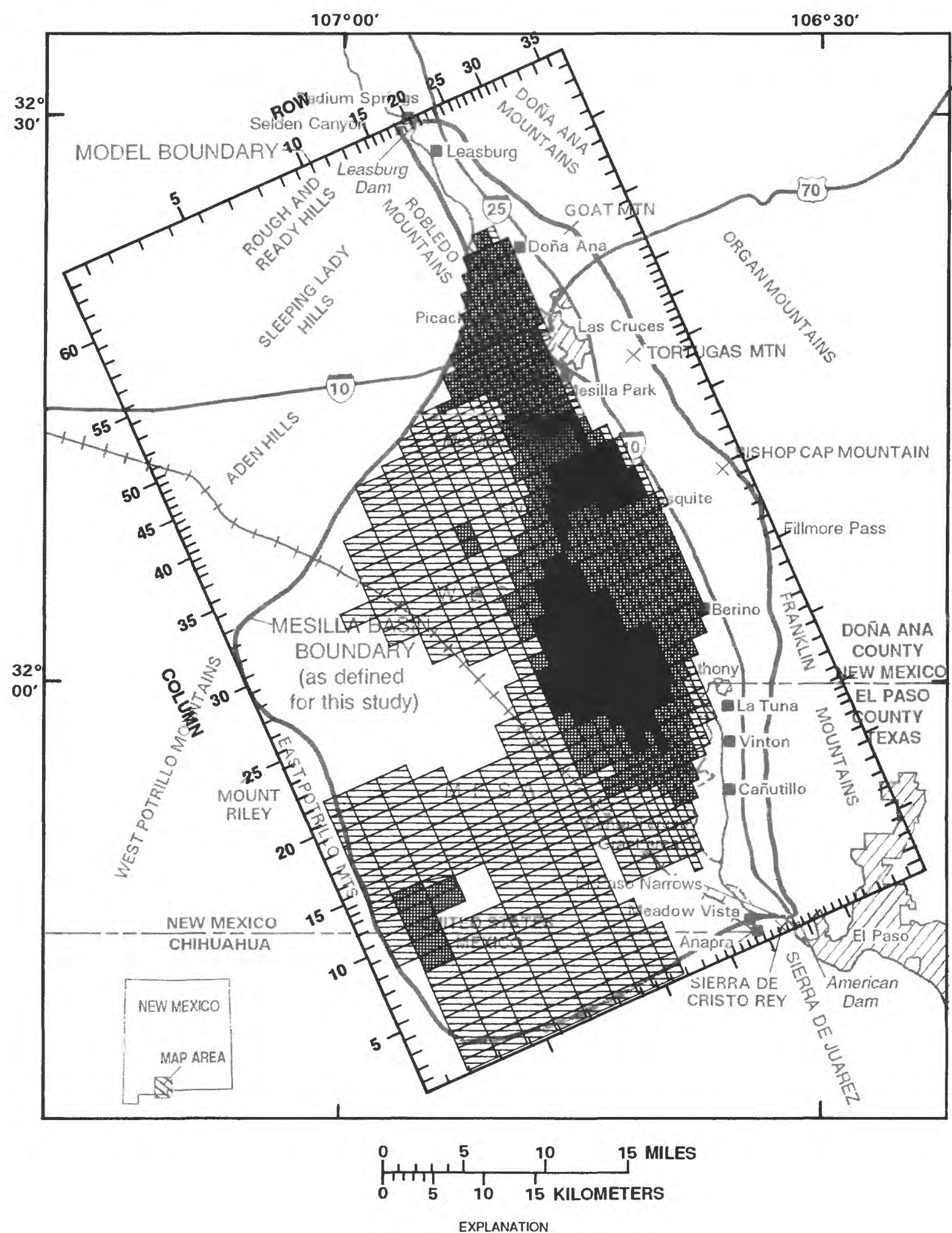

TRANSMISSIVITY, IN FEET SQUARED PER DAY:

$\$$ LESS THAN 6,000

EQUAL TO OR GREATER THAN 12,000 AND LESS THAN 14,000 EQUAL TO OR GREATER THAN 6,000 AND LESS THAN 12,000

Figure 15.--Transmissivity assigned to model layer 4. 
The hydraulic conductivity for the river alluvium was specified as 150 feet per day ( $1.71 \times 10^{-4}$ foot per second) in most of the area of the Mesilla Valley and 350 feet per day (4.05 x 10-3 foot per second) in a few localities (areas marked K1 and K2 on fig. 20 of Frenzel and Kaehler, 1990). These hydraulic-conductivity values were approximately equal to those derived in the previous section on geology.

Values of hydraulic conductivity for the Santa Fe Group were assigned on the basis of location, depth, and hydrostratigraphic unit and changed during model adjustment. The Las Cruces area (model rows 25 and greater, columns 35 and greater) was given smaller values of hydraulic conductivity than the rest of the basin to simulate measured hydraulic heads in Las Cruces. A physical justification for the smaller values is the large number of faults, which are more numerous in the Las Cruces area than elsewhere. As noted previously, reduced transmissivity may be associated with faults because of cementation along fault planes or juxtaposition of clay lenses against sand and gravel lenses.

The horizontal-hydraulic-conductivity values, derived during model adjustment, fall within the upper and lower quartiles of the hydraulicconductivity values discussed in the previous section on geology. Values of hydraulic conductivity for the upper Santa Fe Group hydrostratigraphic unit were 12 feet per day ( $1.39 \times 10-4$ foot per second) in the Las Cruces area and 30 feet per day ( $3.47 \times 10^{-4}$ foot per second) elsewhere. Values of hydraulic conductivity for the middle Santa Fe Group hydrostratigraphic unit where that unit is less than about 600 feet below the water table (layers 1 and 2) were 10 feet per day ( $1.16 \times 10^{-4}$ foot per second) in the Las Cruces area and 20 feet per day (2.31 × $10-4$ foot per second) elsewhere. Where the middle Santa Fe Group hydrostratigraphic unit is deeper than 600 feet below the water table (1ayers 3 and 4), hydraulic-conductivity values were 5 feet per day (5.79 $\mathrm{x}$ 10-5 foot per second) in the Las Cruces area and 10 feet per day (1.16 × 10-4 foot per second) elsewhere. The hydraulic conductivity of the lower hydrostratigraphic unit of the Santa Fe Group was set to 13 feet per day ( $1.50 \times 10^{-4}$ foot per second) throughout the model. Because layers 3 and 4 are inactive in most of the Las Cruces area (figs. 14 and 15), the specification of hydraulic-conductivity values of these two layers for that area had little effect on the simulation.

The hydraulic-conductivity values shown in figure 12 are derived from the hydraulic conductivity assigned to various hydrostratigraphic units. On the left side of figure 12, where layer 1 represents only the shallower part of the middle hydrostratigraphic unit of the Santa Fe Group, the hydraulic conductivity is 20 feet per day. In other places outside the Mesilla Valley, the hydraulic conductivity is between 20 and 30 feet per day, representing partial thicknesses of the middle and upper hydrostratigraphic units of the Santa Fe Group. In the Mesilla Valley, the hydraulic conductivity is influenced by the river alluvium. The largest values of hydraulic conductivity in figure 12 occur where the river alluvium was assigned a hydraulic conductivity of 350 feet per day, except in the north where the large value represents almost entirely river alluvium, caused by the near absence of the Santa Fe Group. The smallest value in figure 12 is in the Las iruces area outside the Mesilla Valley. 
Most of layer 2 was given a transmissivity of 8,000 feet squared per day (fig. 13) where on1y the shallower part of the middle Santa Fe Group was represented. Where transmissivity values shown in figure 13 are greater than 8,000 feet squared per day, part or a11 of the 400-foot thickness of 1ayer 2 represents the upper Santa Fe Group hydrostratigraphic unit. Figure 13 shows where the smaller transmissivity values were assigned in the Las Cruces area. On the eastern edge of layer 3 outside the Las Cruces area, the small transmissivity values are influenced by the thinning of the aquifer.

Where 1 ayer 3 represented only the deeper part of the middle hydrostratigraphic unit of the Santa Fe Group, the transmissivity is 6,000 feet squared per day (fig. 14). Smaller values represent thinning in the southeast and smaller hydraulic-conductivity values assigned to the Las Cruces area. Larger values are shown where the lower hydrostratigraphic unit is represented.

The differences in the transmissivity of layer 4 (fig. 15) mainly reflect the variable thickness of the Santa Fe Group represented. The largest transmissivity values are shown for the deepest part of the basin and the smallest values are shown for the shallowest parts.

\section{Leakance}

Leakances were calculated on the basis of the thicknesses of hydrostratigraphic units between nodes in the vertical direction. Equation 49 of McDonald and Harbaugh (1988, p. 5-12) describes the general method used:

$$
\text { Vcont }_{i, j, k+1 / 2}=\frac{1}{\sum_{g=1}^{n} \frac{\Delta z}{K_{g}}}
$$

Where Vcont is the leakance;

$i$ is the row;

$j$ is the column;

$k+1 / 2$ indicates that the leakance is calculated between layers $k$ and $\mathrm{k}+1$;

$\mathrm{n}$ is the number of hydrostratigraphic units that fall between the two nodes;

$\Delta z$ is the thickness of the gth hydrostratigraphic unit that falls between the two nodes, in feet; and

$\mathrm{K}_{\mathrm{g}}$ is the vertical hydraulic conductivity of the gth hydrostratigraphic unit that falls between the two nodes. $\mathrm{K}$ is equal to the horizontal hydraulic conductivity divided by the horizontal to vertical ratio that was specified for each hydrostratigraphic unit. 
Consider nodes located at row 5, column 17, layers 2 and 3 (fig. 11). Between these two nodes, 200 feet of the upper part of the middle Santa $\mathrm{Fe}$ hydrostratigraphic unit is simulated with an assigned horizontal hydraulic conductivity of 2.31 x 10-4 foot per second (20 feet per day), and an assigned horizontal to vertical ratio of $500: 1$; 160 feet of the lower part of the middle Santa Fe Group hydrostratigraphic unit with an assigned hydraulic conductivity of $1.16 \times 10^{-4}$ foot per second (10 feet per day), and an assigned horizontal to vertical ratio of $500: 1$; and 140 feet of the lower hydrostratigraphic unit with an assigned hydraulic conductivity of $1.50 \times 10-4$ foot per second (13 feet per day) and an assigned horizontal to vertical ratio of 100:1. Converting horizontal hydraulic conductivity to vertical hydraulic conductivity and solving the equation yield a value of Vcont equal to $8.22 \times 10-10$ per second. After model adjustment, the horizontal to vertical ratios were 100:1 for river alluvium, 500:1 for upper and middle hydrostratigraphic units of the Santa Fe Group, and 100:1 for the lower hydrostratigraphic unit of the Santa Fe Group.

Nodes in layer 1 were placed 150 feet from the bottom of the layer. This is consistent with the 300-foot layer-1 thickness of Frenzel and Kaehler (1990).

Specific yield and storage coefficients

The specific yield for layer 1 was 0.2 , and the storage coefficients for layers 2-4 were estimated as the thickness times a specific storage of $1 \times 10-6$ per foot (the same as Frenzel and Kaehler, 1990, p. 54). Thus, in much of the area of layer 2, the thickness was 400 feet and the storage coefficient was 0.0004 . Near the edges of the active part of 1 ayer 2 , where thickness was less than 400 feet, the storage coefficient was less than 0.0004 . Similarly, where the thickness of layer 3 was 600 feet, the storage coefficient was 0.0006 , and less near the edges. Because the thickness of layer 4 varied to as great as 1,030 feet, the storage coefficient varied to as great as 0.00103 . Although the exact specified storage coefficients are not tabulated, they can be calculated on the basis of thickness (table 3 ).

\section{Initial Condition and Time Periods}

The initial (pre-1915) condition was assumed to be steady-state. Because the steady-state model was kept consistent with the transient model by simultaneously adjusting aquifer characteristics in the steady-state transient simulations, the initial condition was not the same as that of Frenzel and Kaehler (1990). However, the method and rationale for generating the initial condition were exactly the same (Frenzel and Kaehler, 1990, p. 45); that is, the model properties used in the steady-state simulation were identical with those in the transient simulation except for time-dependent characteristics. 
The first 16 stress periods were exactly the same as those of Frenzel and Kaehler (1990, p. 56). The additional six stress periods were defined to simulate a relative shortage of water in 1977-78 and to stop at the end of 1984 (end of stress period 21) to enable a comparison to the large number of water-level measurements that were made in the winter of 1984-85. Stress periods 1-16 simulated 1915-19, 1920-26, 1927-40, 1941-47, 1948-50, 1951-53, $1954-57,1958-60,1961,1962-63,1964,1965-66,1967-68,1969-71,1972$, and 1973-75, respectively. Stress periods 17-22 simulated 1976, 1977-78, 1979-80, 1981-82, 1983-84, and 1985, respectively.

\section{Boundary Conditions}

Boundary conditions were defined, similar to those of Frenzel and Kaehler (1990, p. 56). Refinements and corrections led to differences that may not be individually significant, except possibly those in the Mesilla valley boundary.

\section{No-flow boundary}

The exterior boundary of the basin, which is the extent of active model blocks, was different from that of the Frenzel-Kaehler model, but was defined on the same basis. The extent of the active part of layer 1 (fig. 12) was the same as that shown in figure 20 of Frenzel and Kaehler (1990) except southwest of Picacho where the boundary was straightened by activating two blocks (row 6, column 37 and row 7, column 39). Differences in the extent of the active parts of layers 2-4 reflected the more recent interpretation of the geology and the boundary between the Santa Fe Group and bedrock (Hawley, 1984; Seager and others, 1987; and J.W. Hawley and R.P. Lozinsky, written commun., 1988). The main change in the lateral extent of the simulated basin occurs in layer 4. A comparison of figure 15 with figure 23 of Frenzel and Kaehler (1990) shows that layer 4 has been made less extensive in the middle of the west side and more extensive in the southwest corner of the model. Other differences around the eastern and northern edges of the active part of layer 4 generally result in a shift of the simulated boundary of about 1 mile and probably are not significant with respect to the basinwide flow system. Similarly, shifts of the boundaries of layers 2 and 3 with respect to the boundaries simulated by Frenzel and Kaehler probably are not significant. Layer 3 was deactivated in the vicinity of the Las Cruces well field to improve the simulation of hydraulic heads there, as discussed in the section on model adjustment. The basin is not as deep in the Las Cruces well-field area as it is farther west (Hawley, 1984), although the depth is not well known. 


\section{Recharge}

Mountain- and slope-front recharge was located in the same places as shown in figure 25 of Frenzel and Kaehler (1990), and the values were modulated in the same way using precipitation data (Frenzel and Kaehler, 1990, p. 58). However, during model adjustment, recharge on the west side of the basin was doubled to improve the simulation of hydraulic heads in the West Mesa area. This additional recharge on the west side caused an overall increase in mountain- and slope-front recharge of 20 percent. Also, because more precipitation data were available as previously mentioned, the estimated recharge on the east side of the basin was slightly different from that of the Frenzel-Kaehler model. Figure 16 shows location and rates of steady-state recharge for layer 1 and can be compared to figure 25 of Frenzel and Kaehler (1990). The overall steady-state recharge rate was 18 cubic feet per second. Transient recharge rates are shown in figure 17A.

\section{EXPLANATION}

0.353 BLOCK WHERE RECHARGE WAS SPECIFIED--Number is rate, in cubic feet per second $-0.136 \square$ SPECIFIED-HEAD BLOCK--Number is model-derived underflow, in cubic feet per second. Negative sign indicates outflow

MODEL-DERIVED EVAPOTRANSPIRATION, IN ACRE-FEET PER ACRE PER YEAR:

0

GREATER THAN O AND LESS THAN OR EQUAL TO 1.5

GREATER THAN 1.5 AND LESS THAN OR EQUAL TO 3.5

GREATER THAN 3.5 AND LESS THAN OR EQUAL TO 5.5 


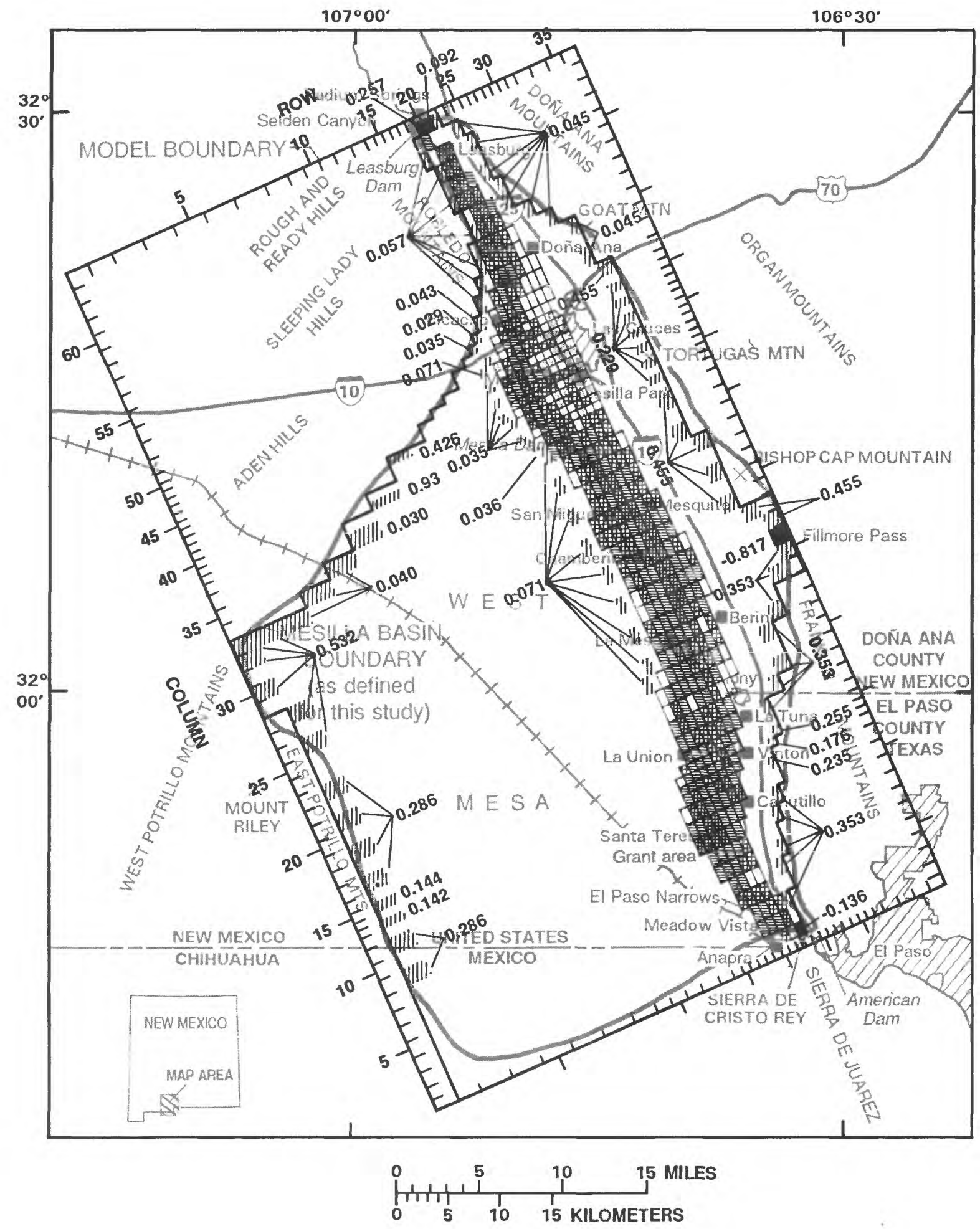

Figure 16.--Recharge, underflow, and evapotranspiration boundaries for layer 1, steady-state simulation. 
A. MOUntaIn. AND SLope-fRont REchaRoe

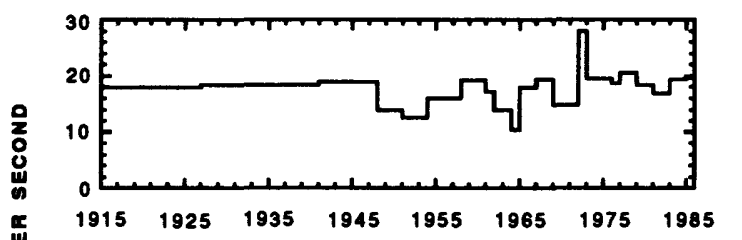

B. NET IRRIGATION FLUX

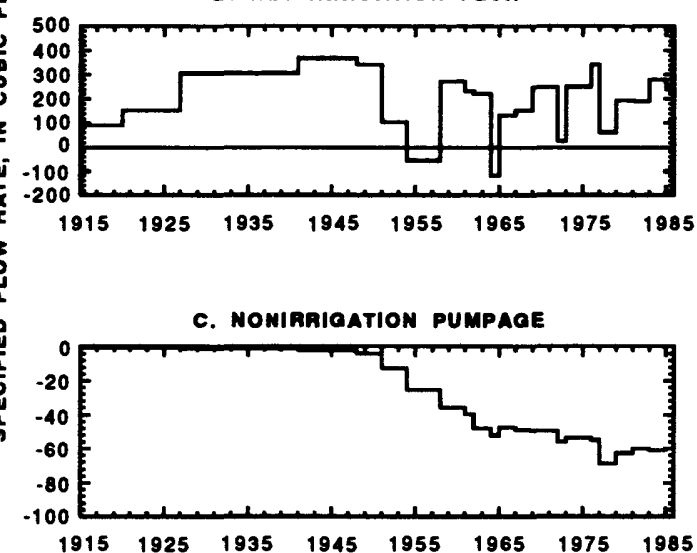

VALUES IN GRAPHS A.C ARE SPECIFIED. VALUES IN D-G ARE MODEL-DERIVED.
D. RIVER SEEPAOE

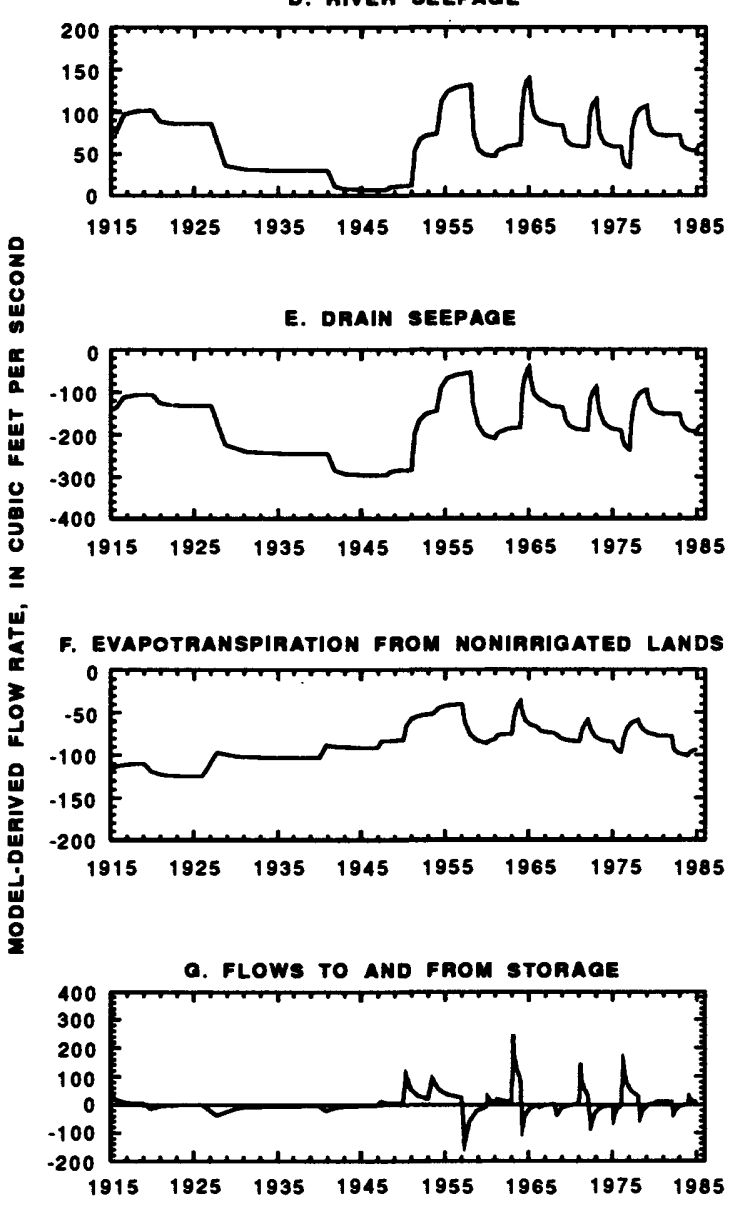

Figure 17.--Major basinwide flow rates. 


\section{Underflow}

Underflow through the flood-plain alluvium in Selden Canyon and E1 Paso Narrows was simulated with specified-head boundaries exactly as was done by Frenzel and Kaehler (1990, p. 60), and an additional specified-head boundary was used to simulate flow out of the basin through Fillmore Pass. A specified head of 3,814 feet in row 36, column 26, layers 1 and 2 simulated the measured heads near Fillmore Pass. The model-derived steady-state inflow rate of about 0.35 cubic foot per second at Selden Canyon and outflow of about 0.14 cubic foot per second at El Paso Narrows compare with 0.15 and 0.09 cubic foot per second in the Frenzel-Kaehler model. The steady-state outflow of 0.99 cubic foot per second at Fillmore Pass ( 0.82 cubic foot per second from 1 ayer 1 and 0.17 cubic foot per second from layer 2) was not simulated in the FrenzelKaehler model. These values are not significant with respect to the overall mass balance of the model, which was 300 cubic feet per second under steadystate conditions. Steady-state underflows at specified-head blocks are shown in figure 16 for layer 1. Under transient conditions, the model-derived inflow and outflow rates at specified-head boundaries were about 2 cubic feet per second.

Mesilla Valley boundary

As described in Frenzel and Kaehler (1990, p. 60):

A complex boundary at or near the land surface in the Mesilla Valley was approximated by three overlapping boundary conditions. They were: (1) A head-dependent flux to approximate flow to and from the river and drains; (2) another head-dependent flux to approximate evapotranspiration from nonirrigated lands; and (3) a specified net irrigation flux to approximate the summation of effective rainfall and net diversions (positive) and evapotranspiration from irrigated lands (negative) [fig. 17, graph B]. By implication, pumpage for irrigation from layer 1 is included in this summation because evapotranspiration is accounted for directly.

Flow to and from the river and drains. - The locations of flow to and from the river and drains are shown in figures 27 and 28 of Frenzel and Kaehler (1990). The conductances assigned to the river and drains were the same as those of Frenzel and Kaehler (1990, p. 60-65, table 3). The altitudes assigned to the river and drains were set 1 foot lower than those of Frenzel and Kaehler, consistent with their suggestion (p. 101).

Surface-water inflow was assigned to the farthest upstream river node for Selden Canyon exactly the same as in Frenzel and Kaehler (1990, p. 65), and inflow from 1975 to 1985 was calculated in the same way. Inflows to river reaches including municipal return flows are shown in table 4. Other river specifications are shown in table 3 of Frenzel and Kaehler. 
Evapotranspiration from nonirrigated lands. - Evapotranspiration from nonirrigated lands in the Mesilla Valley was simulated in the same way as described by Frenzel and Kaehler (1990, p. 65) except that the evapotranspiration surface (McDonald and Harbaugh, 1988, p. 10-1) was corrected to more closely correspond to the land surface, and the extinction depth (the depth below the evapotranspiration surface at which model-derived evapotranspiration is zero) was reduced from 15 feet to 12 feet. The effect of corrections to the evapotranspiration surface was to make evapotranspiration more uniform (compare fig. 16 of this report with fig. 25 of Frenzel and Kaehler, 1990). The extinction depth was reduced in order to reduce the model-derived depletion. The maximum evapotranspiration from nonirrigated lands was specified to be 5.5 acre-feet per nonirrigated acre, exactly the same as that of Frenzel and Kaehler (1990, p. 65-66). Evapotranspiration from nonirrigated land was simulated for the entire valley, and to avoid overestimating it, the maximum rate of 5.5 feet was multiplied by a factor equal to the nonirrigated acreage divided by the total valley acreage.

The overall rate of evapotranspiration in the transient simulation is shown in figure 17F. The model-derived evapotranspiration for 1975 was 85 cubic feet per second. If this evapotranspiration is assumed to occur on 32,000 acres (Frenzel and Kaehler, 1990, p. 66), this is the equivalent of 1.9 acre-feet per acre. This compares with the Frenzel-Kaehler value of about 2.5 acre-feet per acre. Model-derived evapotranspiration for 1975 shown in figure 18 is similar to figure 29 of Frenzel and Kaehler (1990) except that evapotranspiration shown in figure 18 is more evenly distributed as a result of corrections to the simulated altitude of the evapotranspiration surface.

Evaporation from streams. - Evaporation from streams was treated outside of the model the same way as by Frenzel and Kaehler (1990, p. 66). That is, 16,000 acre-feet was subtracted from annual measured flows passing Leasburg Dam before routing through the stream system, and this amount (equivalent to 22 cubic feet per second) was added in the calculation of model-derived depletion.

Net irrigation flux.-- Net irrigation flux was treated the same way as by Frenzel and Kaehler (1990, p. 66). The flux of the first stress period was the same as that of Frenzel and Kaehler and later stress periods were derived from figure 8 , curve $E$ in the same way. The net irrigation fluxes for each stress period are shown in figure 17B. Although values in figure 17B are not the same as those in Frenzel and Kaehler (1990, fig. 26B), the curves have a similar shape. 

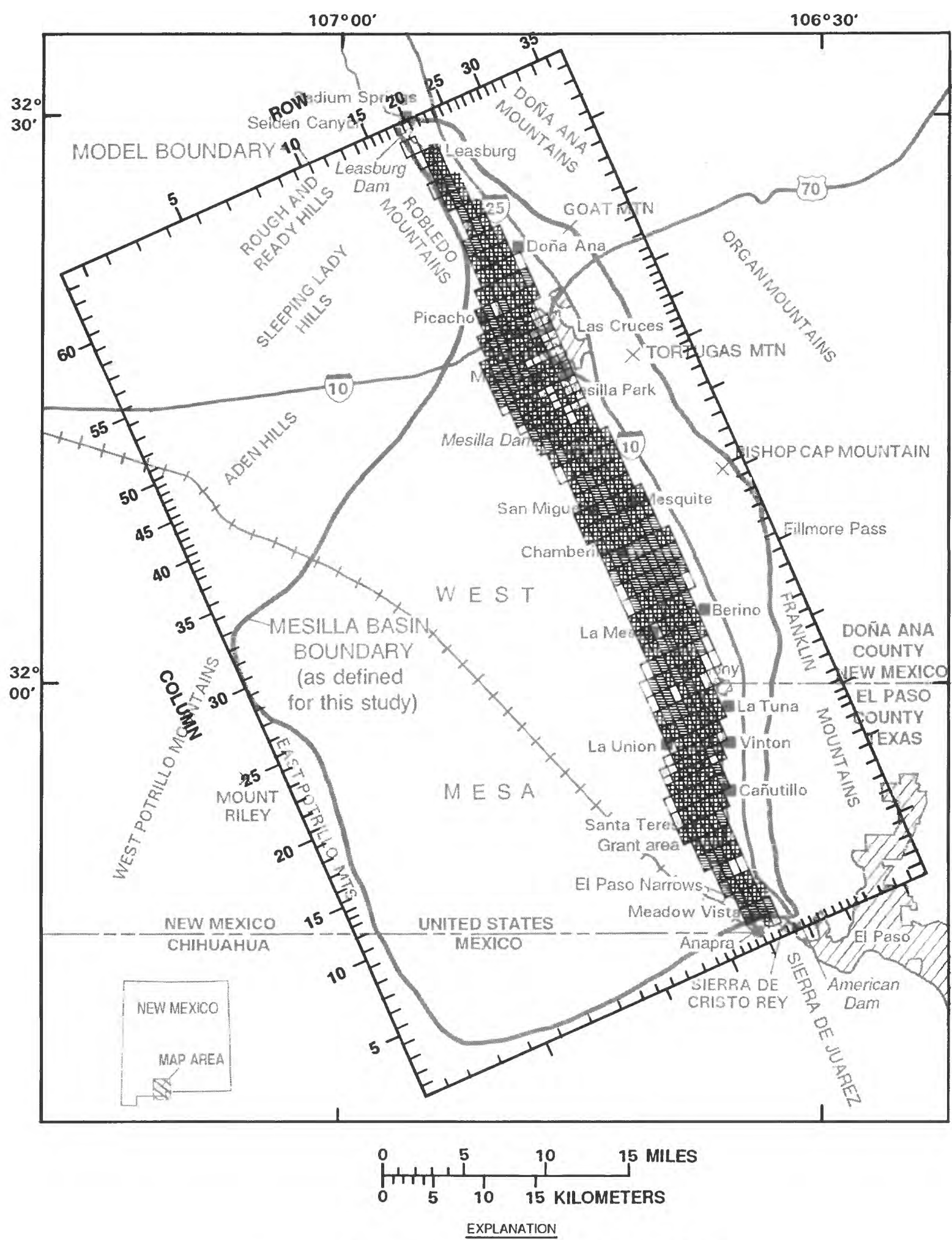

EVAPOTRANSPIRATION, IN ACRE-FEET PER ACRE PER YEAR:

G GREATER THAN O AND LESS THAN OR EQUAL TO 08

Figure 18.--Model-derived evapotranspiration from nonirrigated lands for 1975 and area of net irrigation flux. 
Nonirrigation withdrawals. - Nonirrigation ground-water withdrawals were treated the same way as by Frenzel and Kaehler (1990, p. 69). Return flows generally were treated in the same way also except that return flows at Anthony were assumed to have been via the East Drain after 1975 and return flows at Santa Teresa were assumed to have taken the form of ground-water recharge after 1975. Because part of the withdrawals at Santa Teresa were for irrigation of sod and the sewage effluent was disposed of by 1 and application, return flows were assumed to be 25 percent of withdrawals, a value less than the assumed 50-percent returns from other municipal usage. Nonirrigation ground-water withdrawals for the first 16 stress periods were the same as those of Frenzel and Kaehler (1990, table 4), except for a few corrections. Simulated nonirrigation ground-water withdrawals are shown in table 5 . The totals for each stress period are shown in figure 17C, which is comparable to figure 9, line $\mathrm{E}$.

\section{Mode1 Ad justments}

The general goal of model adjustment was to make model-derived values, such as hydraulic head, match measured values reasonably well while keeping simulated properties, such as hydraulic conductivity, within generally recognized ranges for the type of deposits simulated. The model, with the refinements described above, needed little adjustment. Boundary conditions were similar to those in the Frenzel-Kaehler mode1 (1990), and with few exceptions were assumed not to need more adjustment.

The emphasis in adjustment of the revision of the model was on the simulated values of hydraulic conductivity of the Santa Fe Group. The main difference between this mode1 and the Frenzel-Kaehler model was the way in which transmissivity values and leakances were derived. However, the correct simulation of the effects of ground-water withdrawals on streamflow in the Rio Grande depends on the specification of correct aquifer characteristics for the Santa Fe Group. As Frenzel and Kaehler (1990, p. 98) showed, this becomes more critical as the point of withdrawal is moved more distant from the Mesilla Valley boundary. Because transmissivity and leakance largely determine the time required for the effects of ground-water withdrawals to reach the river, the adjustment of Santa Fe Group hydraulic-conductivity values was given special emphasis.

\section{System Properties Used for Comparison}

As in the Frenze1-Kaehler mode1, measured values of hydraulic head, river depletion, and drain discharge were compared with model-derived values. Because depletion and drain discharge are closely related to the Mesilla Valley boundary, which was not emphasized in the adjustment of this mode1, hydraulic-head comparisons received more emphasis. 


\section{Surface-water depletions}

Annual surface-water depletions were calculated as the measured discharge of the Rio Grande at Leasburg Dam minus the measured discharge of the Rio Grande at El Paso Narrows. This depletion is referred to as "measured" depletion (fig. 19). Similarly, depletion calculated as stress period-averaged discharge at Leasburg Dam minus model-derived discharge at El Paso Narrows is referred to as "model-derived" depletion. Measured and model-derived depletions were calculated the same way as by Frenzel and Kaehler (1990, p. 78). Figure 19 compares favorably with figure 39 of Frenzel and Kaehler (1990). Each point of the curve representing model-derived values in figure 19 is for the end of a time step.

Differences between measured and model-derived depletion were large before the $1950^{\prime} \mathrm{s}$. This could be partly because the model simulated the progress of drainage ditching and the concurrent changes on ground-water storage with only a few stress periods. Also, irrigated agriculture may have changed over the years in ways that the model did not simulate. For example, the consumption of water by any given crop might have changed over the long term because of changing varieties and irrigation practices.

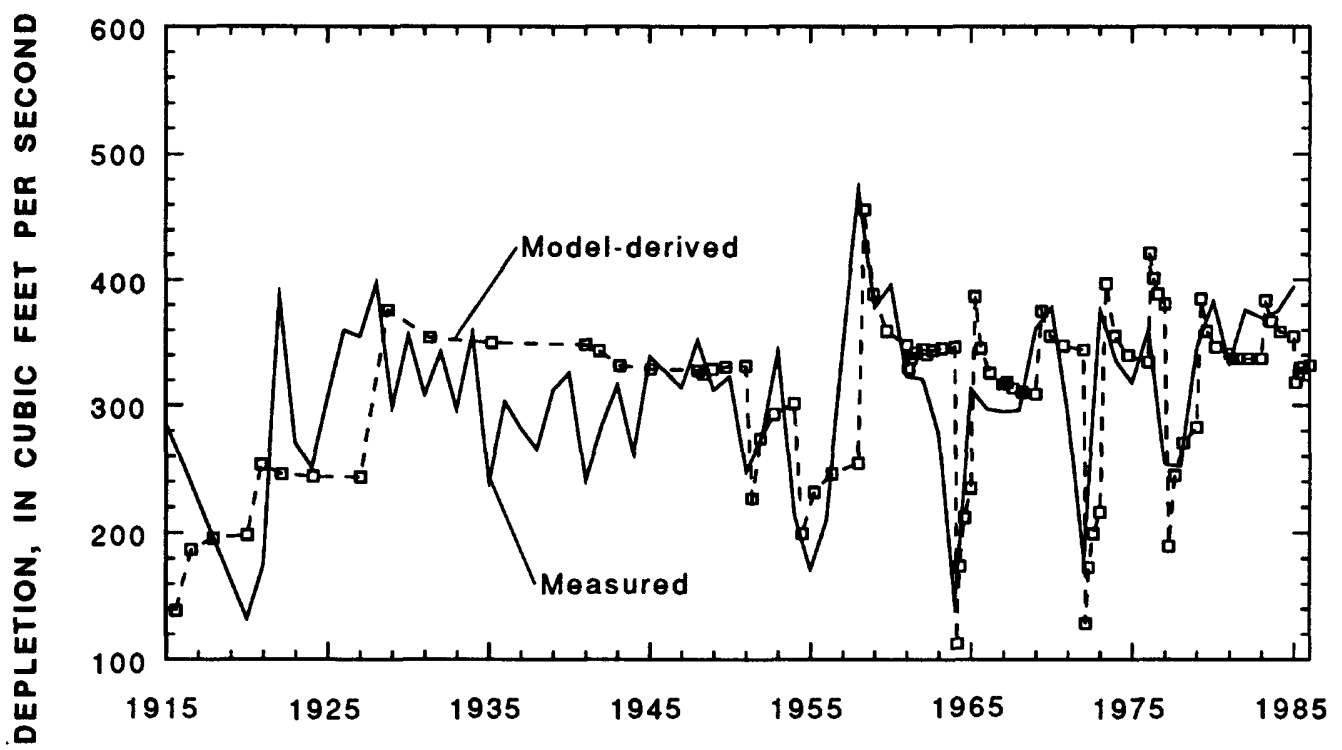

Figure 19.--Relation of annual surface-water depletions calculated from measured discharges to depletions calculated from model-derived discharges. 
The summation of measured depletions versus the summation of annual model-derived depletions is shown in figure 20. Each point plotted in figure 20 represents the summation 1 year later than the previous point. The straight, diagonal line in figure 20 is the line of equality between measured and model-derived values. During periods when the slope of the line defined by the points is approximately parallel to the line of equality (such as 1945-55), the model-derived depletions are approximately equal to measured values. When the points define a line that is steeper than the line of equality (such as 1930-45), model-derived depletions are larger than measured depletions. During much of the 16-year period 1965-80, model-derived depletions are slightly larger than measured values; after that the trend changes slightly so that, taken as a whole during the last 20 years of simulation, model-derived depletions are approximately equal to measured values. To construct figure 20, annual model-derived depletions were estimated by linear interpolation between time steps.

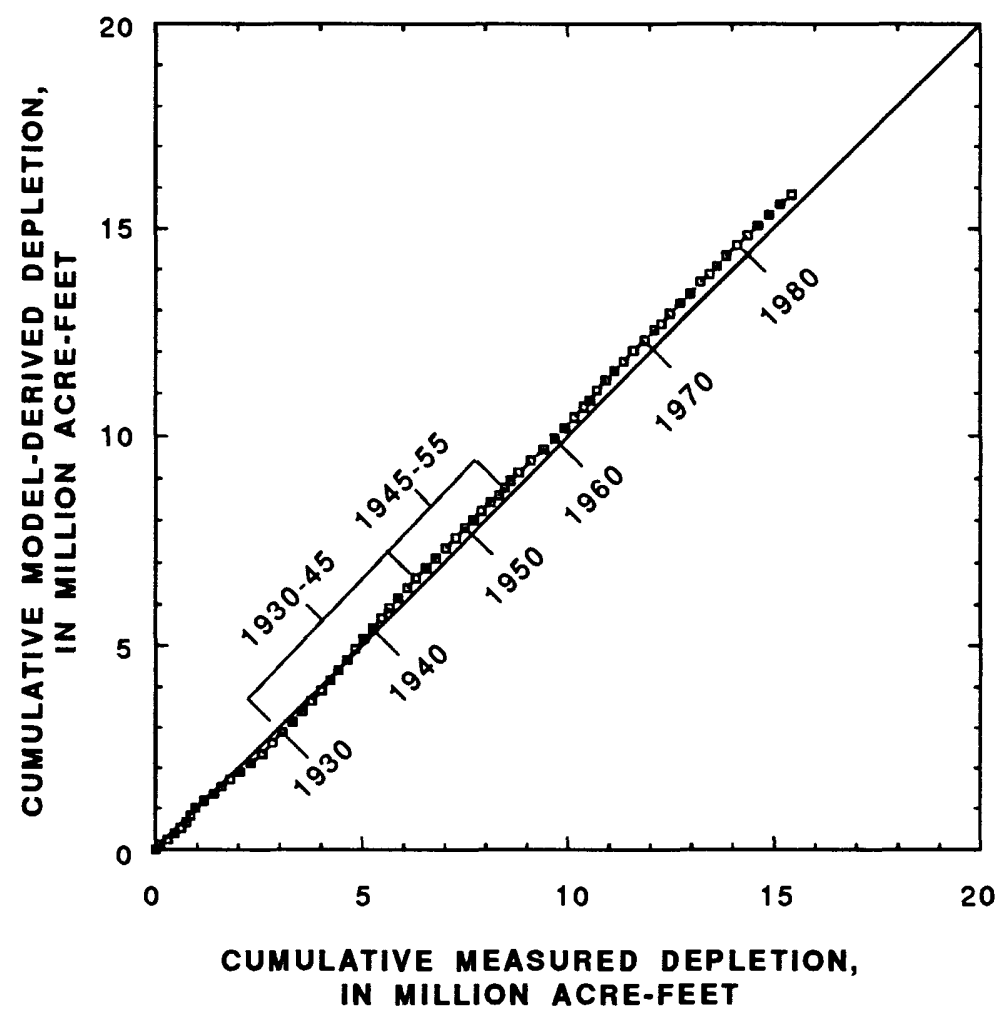

Figure 20.--Relation of cumulative surface-water depletions calculated from measured discharges to cumulative depletions calculated from model-derived discharges. 


\section{Drain discharges}

Measured and model-derived drain discharges were compared to assure that model adjustments did not adversely affect model-derived drain discharge. Model-derived drain discharge is largely dependent on specified drain-bottom hydraulic conductivity, which was not adjusted; therefore, model-derived drain discharges were not expected to be much different from those of Frenzel and Kaehler (1990). The comparison between measured and model-derived discharges before 1975 (fig. 21) is similar to that of Frenzel and Kaehler (1990, fig. 40). The comparison between measured and model-derived discharges after 1975 is similar to before 1975 except at East Drain. There, measured values trend upward whereas model-derived values continue a 30-year downward trend. The reason for this divergence is not known. The accuracy of drain-discharge measurements is poor (Frenzel and Kaehler, 1990, p. 39 and 83).

Hydraulic heads

The same measured hydraulic heads were used for 1947 and 1975 comparisons as used by Frenzel and Kaehler (1990). In addition, hydraulic heads for 1985 were used. The comparison of individual measured and model-derived hydraulic heads is shown in table 6, which is similar to table 5 of Frenzel and Kaehler (1990). The average of the differences shown in table 6 was calculated in four ways: the arithmetic mean, the mean of absolute values of the differences ("mean absolute" difference), the median, and the root-mean-square as explained in Frenzel and Kaehler (1990, p. 72). Differences for 1947, 1975 , and 1985, calculated from 181 locations, were averaged together (bottom of table 6). The arithmetic mean difference of 1.4 feet and median of 0.90 foot indicate that the model-derived hydraulic heads are, on average, slightly higher than measured values. The mean absolute difference of 7.34 feet compares favorably with values in table 8 of Frenzel and Kaehler (1990). The mean absolute difference was used as the primary statistic in deciding if one simulation was better than another. The simulated hydraulic-conductivity values of the Santa Fe Group hydrostratigraphic units were adjusted to minimize the mean absolute difference. The root-mean-square difference of 12.43 feet emphasizes the large differences for 1947 on the west side of the basin, but is similar to root-mean-square differences of Frenzel and Kaehler (1990, tables 5 and 8 ). 

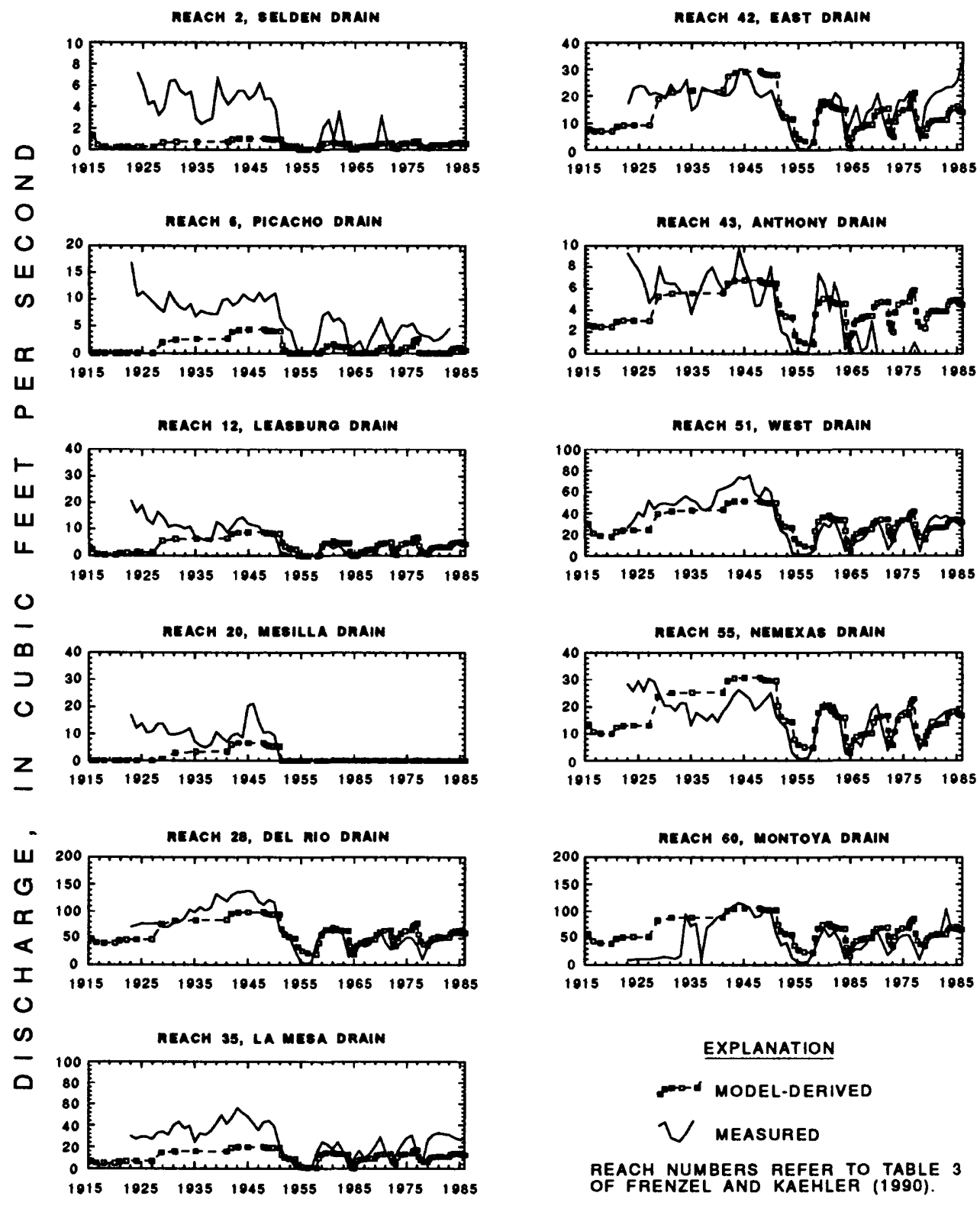

Figure 21.--Measured and model-derived drain discharges. 
To increase the sensitivity to changes in simulated Santa Fe Group aquifer characteristics, only hydraulic heads outside of the Mesilla Valley or in the deeper parts of the aquifer (represented by layers 2 and 3 ) were compared to model-derived values during the adjustment of Santa Fe Group aquifer characteristics. Specified Santa Fe Group aquifer characteristics can be adjusted only on the basis of a statistic that is sensitive to the adjustments. Frenze1 and Kaehler (1990, p. 95-101) found that the differences between measured and model-derived values generally were not very sensitive to Santa Fe Group aquifer characteristics. This is especially true of hydraulic heads in the shallow part of the aquifer in the Mesilla Valley, which are largely determined by the Mesilla Valley boundary. About one-half of the sites shown in table 6 are in this category. The remaining 90 sites, marked by an asterisk in table 6 , were used in calculating the averages shown at the bottom of table 6. Adjustments of Santa Fe Group aquifer characteristics were made mainly on the basis of minimizing the mean absolute difference between measured and model-derived hydraulic heads at the sites outside of the Mesilla Valley.

Measured hydraulic heads are compared to model-derived potentiometric surfaces in figures 22-24. The comparison of measured hydraulic heads and the model-derived steady-state potentiometric surface for layer 1 (fig. 22) is slightly better than that of Frenzel and Kaehler (1990, fig. 31) in the West Mesa area. Similarly, the 1975-76 comparison for the West Mesa area (fig. 23) is slightly better than that of Frenzel and Kaehler (1990, fig. 33). The 1975-76 comparison for the Mesilla Valley area generally is good and similar to that of Frenzel and Kaehler (1990), and the Mesilla Valley boundary was the same in both models. The model-derived potentiometric surface may be about 520 feet too high in the Cañutillo area because several measured values there are all lower than the model-derived surface. The 1984-85 comparison (fig. 24) also shows a reasonably good match between measured hydraulic heads and the model-derived potentiometric surface for the West Mesa area, but no measured values were found for the well-field areas. Hydrographs of measured and model-derived hydraulic heads for well-field locations are compared in figure 25. Generally the trends are the same as those of Frenzel and Kaehler (1990, fig. 36) with some improvement in the Las Cruces area.

\section{System Properties Adjusted}

Simulated extinction depth of evapotranspiration (part of the Mesilla Valley boundary), recharge rates on the west side of the basin, basin depth near Las Cruces, specific yield, and specific storage were adjusted during transient simulations. Values of hydraulic conductivity of the Santa Fe Group were adjusted during and after the other adjustments. 


\section{Extinction depth}

The increase in simulated evapotranspiration from irrigated 1 and (over that of the Frenzel-Kaehler model) caused model-derived depletion of the Rio Grande to be too large. To correct this, the extinction depth (McDonald and Harbaugh, 1988, p. 10-1) of evapotranspiration from nonirrigated land was reduced from 15 to 12 feet. At this point, model-derived drain discharges (fig. 21), depletion of the Rio Grande (figs. 19 and 20), and hydraulic heads in layer 1 ( table 6) for the Mesilla Valley matched measured values reasonably well. Additional model adjustments were made on the basis of minimizing the mean absolute difference between measured and model-derived hydraulic heads at depth and outside of the Mesilla Valley (marked with an asterisk in table 6).

\section{Recharge}

Mountain-front recharge for the west side of the basin was adjusted to improve the simulation of hydraulic heads for that area. As can be seen in table 5 of Frenzel and Kaehler (1990), the differences between measured and model-derived hydraulic heads for 1947 and 1975 are generally negative for rows 1-19 and positive for rows 20-36. Because trial-and-error adjustments of aquifer characteristics did not seem to correct this "skewness," simulated recharge values on the west side of the basin were doubled to achieve the desired effect. This increased recharge resulted in an overall increase of about 20 percent in simulated mountain-front recharge. From this point on, model adjustment was focused on Santa Fe Group aquifer characteristics, although storage was adjusted for the entire model.

Specific yield and specific storage

Specific yield for layer 1 was originally specified as 0.2 and specific storage for layers 2-4 as 1 x 10-6 per foot. Although the specific yield and specific storage were adjusted, the final values were the same as the values originally specified. 


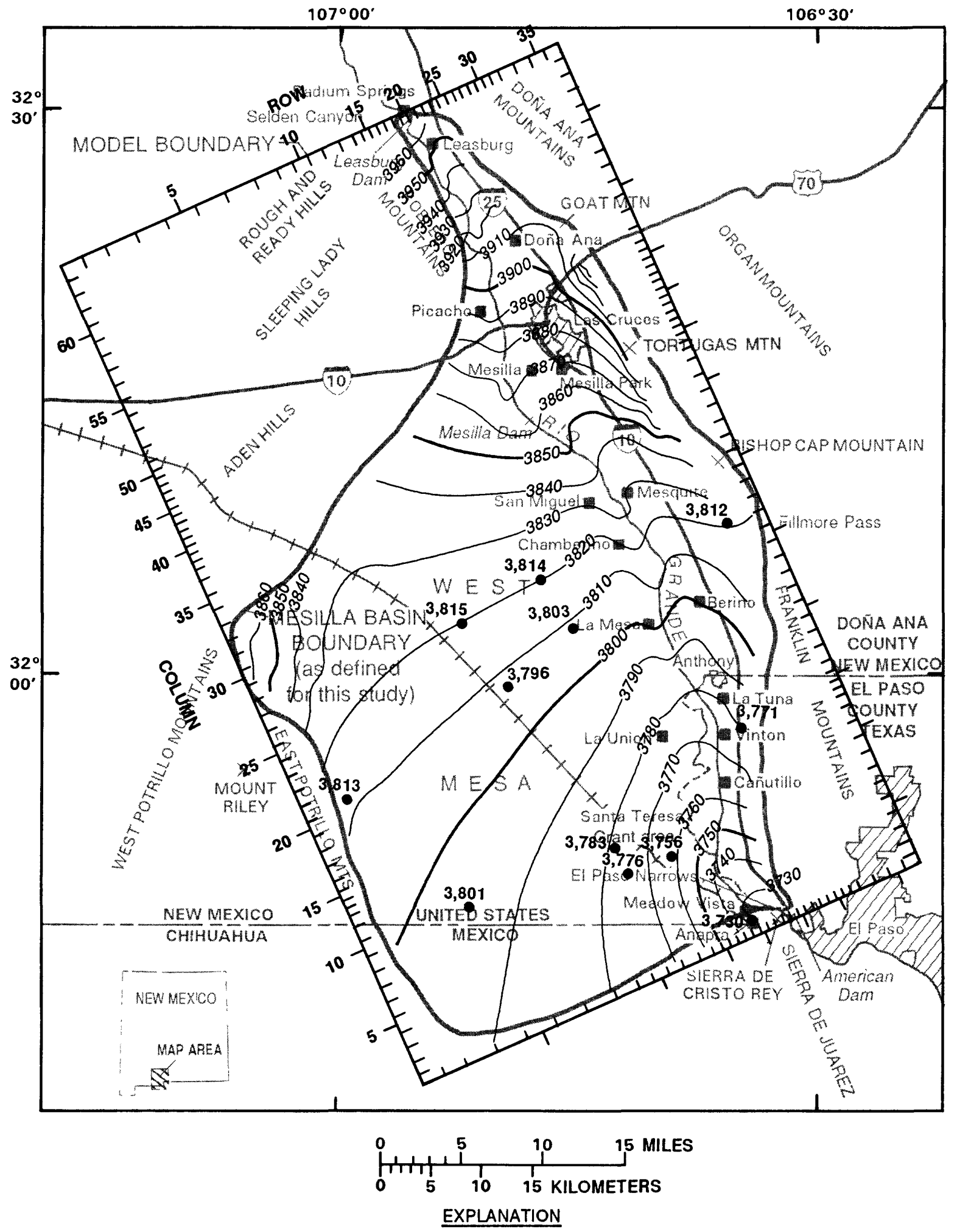

-3730-MODEL-DERIVED POTENTIOMETRIC CONTOUR--Shows simulated altitude at which water would have stood in tightly cased wells. Contour interval 10 feet. Datum is sea level

3,730 WELL--Number is measured hydraulic head, in feet above sea level

Figure 22.--Measured hydraulic heads and model-derived steady-state potentiometric surface, layer 1. 


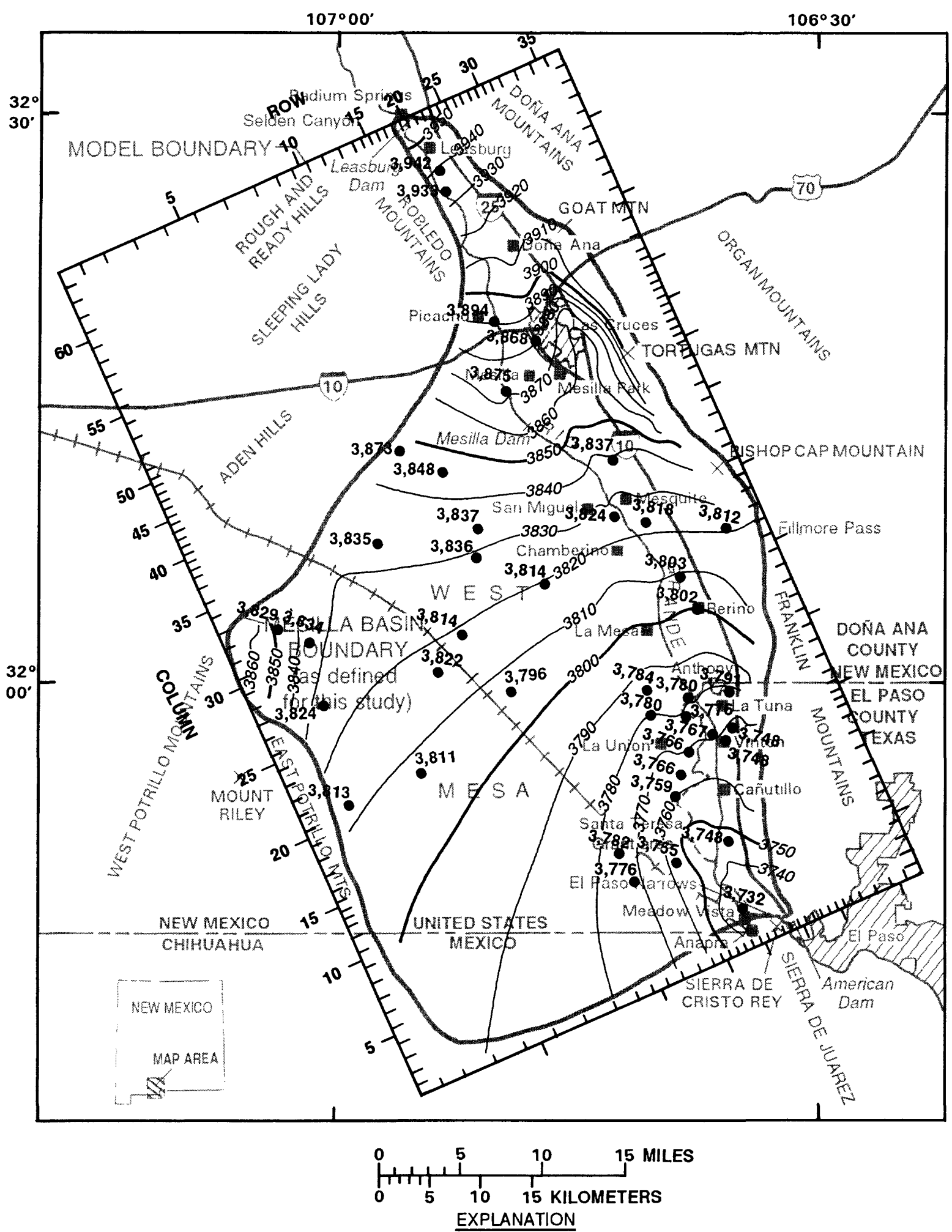

-3750 - MODEL-DERIVED POTENTIOMETRIC CONTOUR--Shows simulated altitude at which water would have stood in tightly cased wells. Contour interval 10 feet. Datum is sea level

3,732 WELL--Number is measured hydraulic head in 1975-76, in feet above sea level

Figure 23.--Measured hydraulic heads and model-derived potentiometric surface for 1975-76, layer 1. 


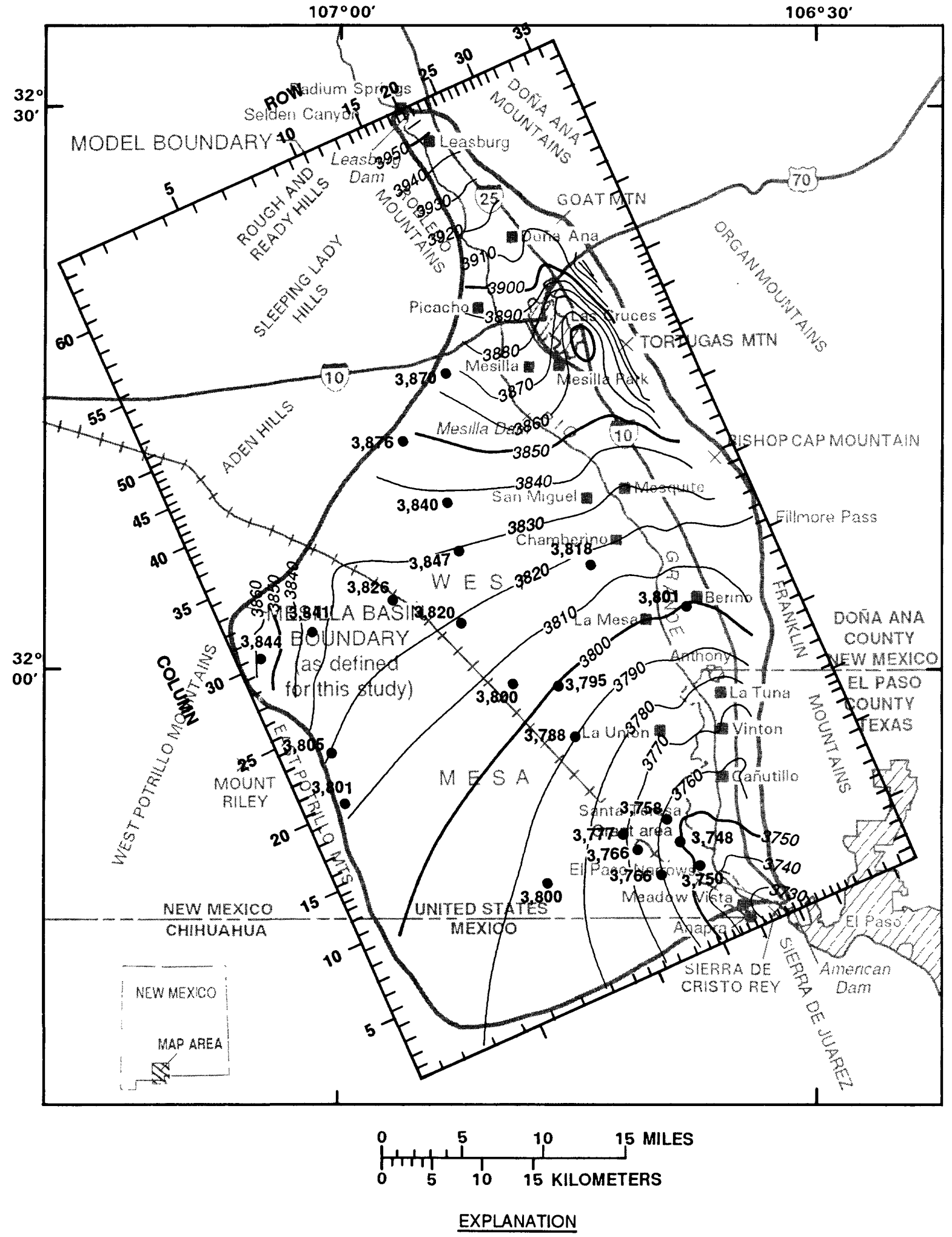

-3800 - MODEL-DERIVED POTENTIOMETRIC CONTOUR--Shows simulated altitude at which water would have stood in tightly cased wells. Contour interval 10 feet. Datum is sea level

- 3,801 WELL.-Number is measured hydraulic head in 1984-85, in feet above sea level

Figure 24.--Measured hydraulic heads and model-derived potentiometric surface for 1984-85, layer 1. 
$12143148541063401 \mathrm{JL} 4912501$

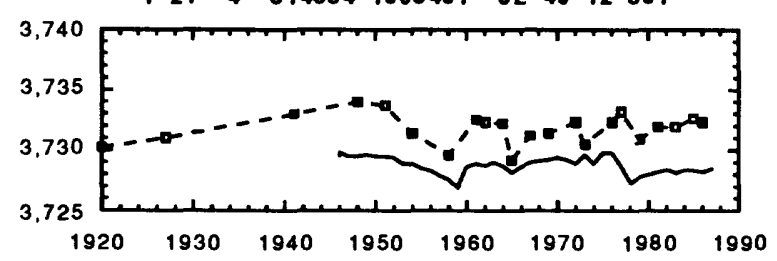

$\begin{array}{llllllll}121 & 15 & 315639 & 1063804 & 275 & 03 E & 21 & 42\end{array}$

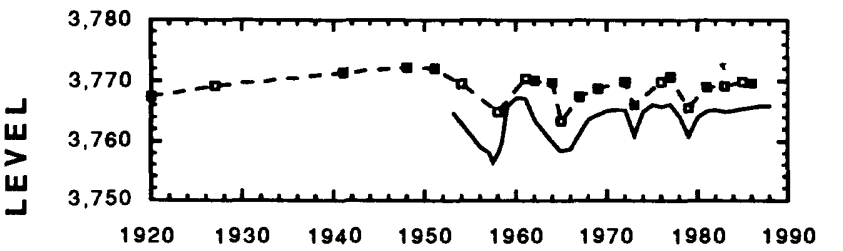

$<$

$\boldsymbol{\omega}$

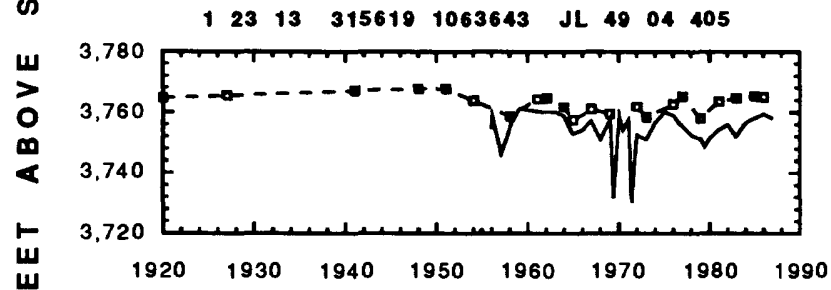

u

2

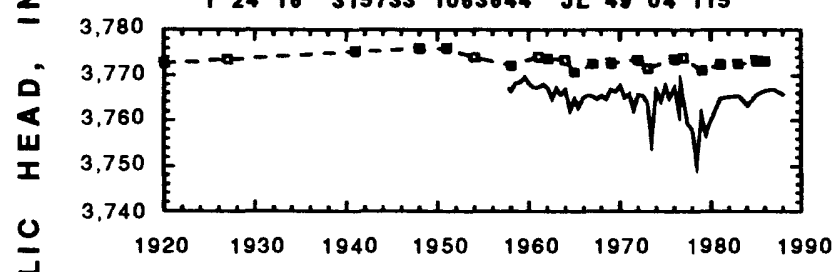

$\begin{array}{lllllll}126 \quad 36 \quad 315804 & 1063543 \quad \mathrm{JL} & 49 & 04 & 138\end{array}$

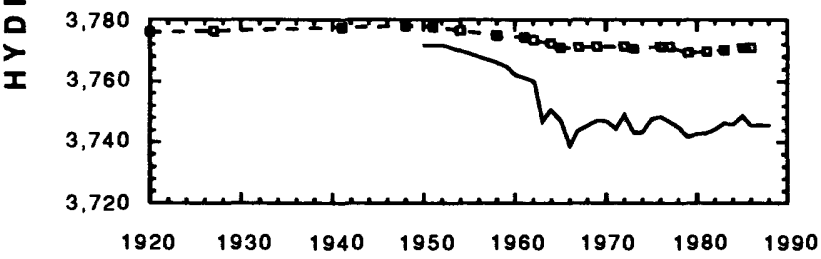

$\begin{array}{lllllllll}2 & 21 & 19 & 315918 & 1063913 & 27 S & 03 E & 05 & 41\end{array}$

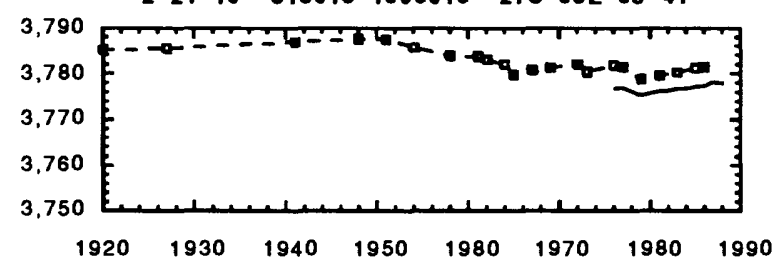

$\begin{array}{llllll}2 & 22 & 12 & 315554 & 1063657 & \mathrm{JL}\end{array} 4904418$

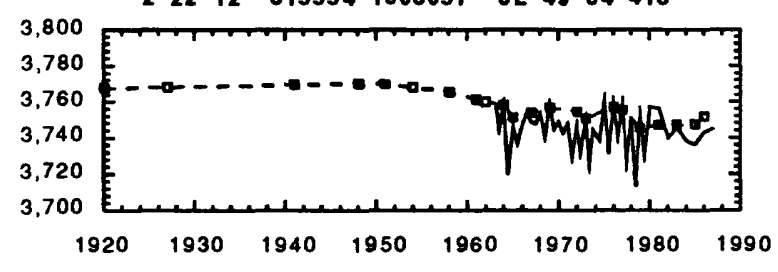

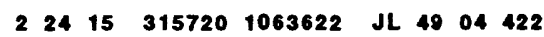

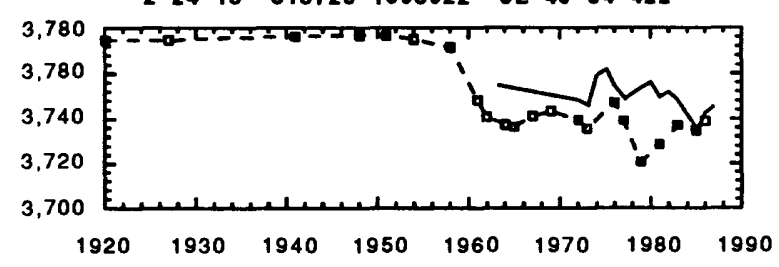

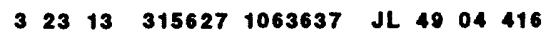

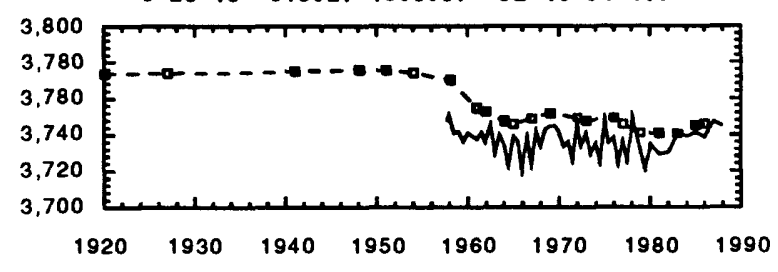

$\begin{array}{lllllllll}3 & 24 & 15 & 315703 & 1063643 & \text { JL } & 49 & 04 & 402\end{array}$

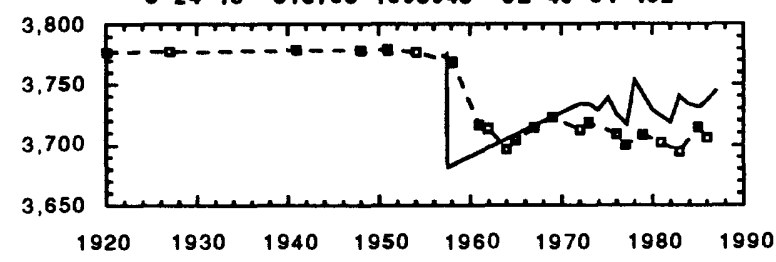

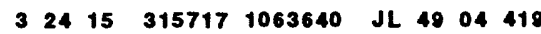

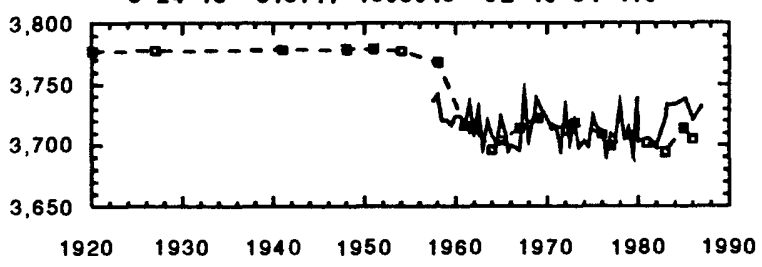

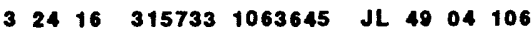

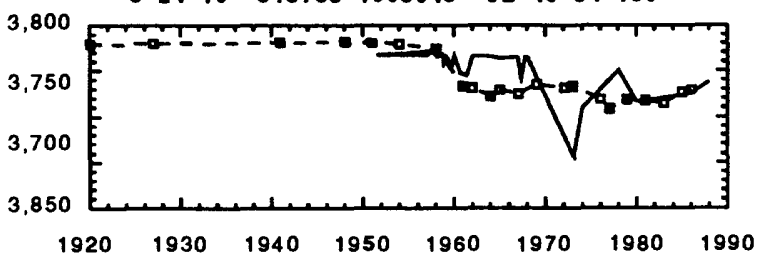




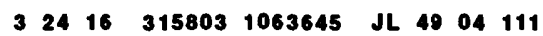

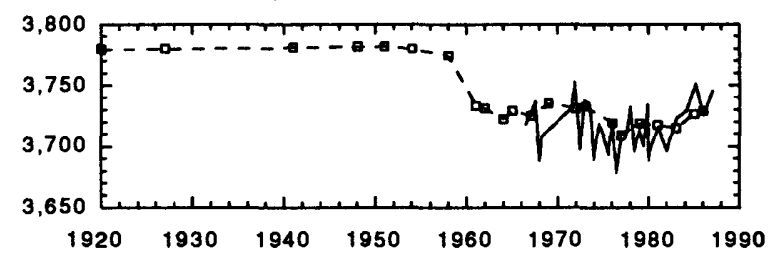

$\begin{array}{lllllllll}3 & 25 & 16 & 315807 & 1063629 & \text { JL } & 49 & 04 & 105\end{array}$

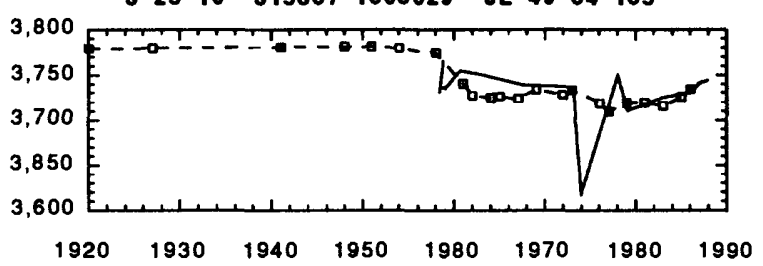

$\begin{array}{lllllllll}125 & 46 & 321818 & 1064704 & 23 S & \text { O2E } & 18 & 31 & \text { LC }\end{array}$

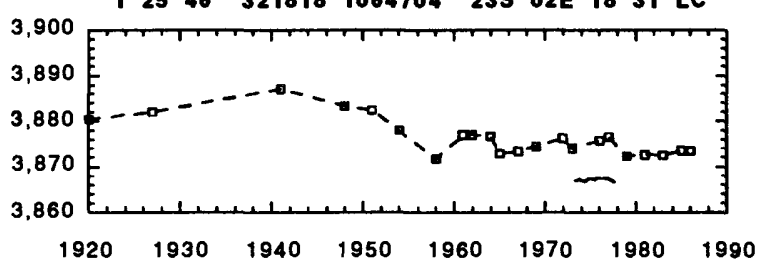

$\begin{array}{lllllllll}2 & 27 & 48 & 321914 & 1064625 & 235 & 02 E & 07 & 41 \\ \text { LC }\end{array}$

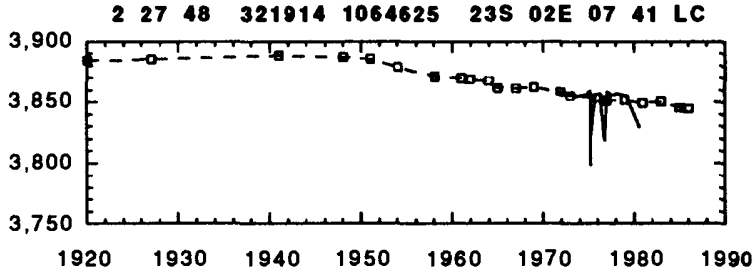

$\begin{array}{lllllllll}2 & 28 & 46 & 321853 & 1064521 & 235 & 02 E & 08 & 44 \\ \text { LC }\end{array}$
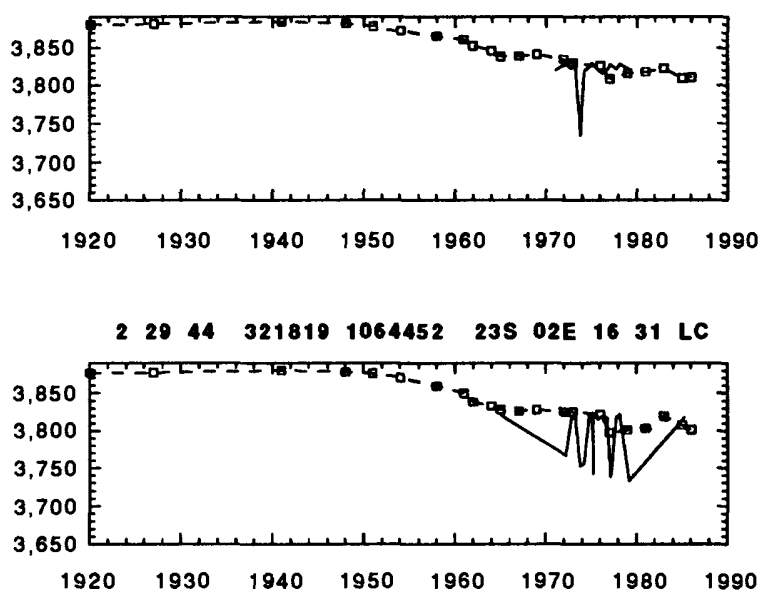

22641 NEW MEXICO STATE UNIVERSITY AREA

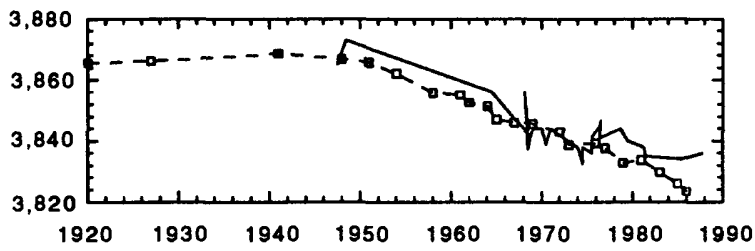

12642 NEW MEXICO STATE UNIVERSITY AREA

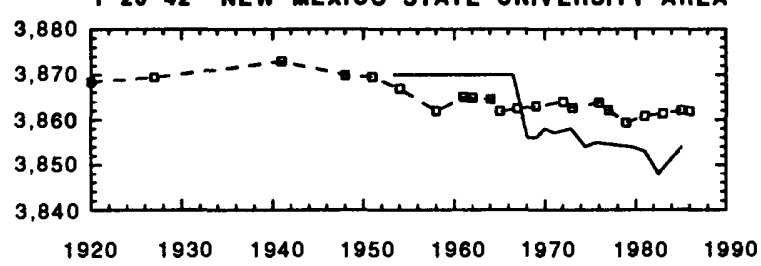

EXPLANATION

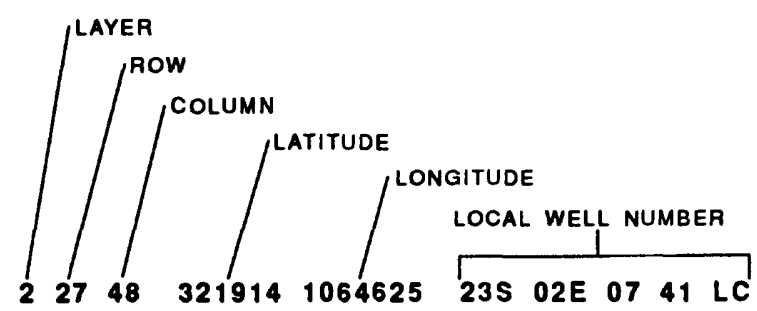

Graphs marked LC are for wells in the vicinity of Las Cruces

Graphs marked NEW MEXICO STATE UNIVERSITY AREA are composites of water levels at several wells

Other graphs are for wells in the vicinity of Cañutillo. Number is Texas local well number

\section{Po-d MODEL-DERIVED \\ W MEASURED}

Figure 25.--Measured and model-derived hydraulic heads. 


\section{Model boundary}

The no-flow boundary of model layer 3 was moved westward about 1 mile in the Las Cruces area (rows 26-27, columns 40-56) to increase simulated drawdowns and thereby improve the simulation of hydraulic heads in the Las Cruces well field. The basin is not as deep in the Las Cruces well field as elsewhere, and is simulated by two layers. The locality where the basin becomes deeper is not precisely known. The model-derived heads of Frenzel and Kaehler (1990, fig. 36) were between 10 and 40 feet higher than measured values, differences that are difficult to attribute entirely to errors or anomalies in the measured values. To improve the fit between measured and model-derived hydraulic heads, measures were taken to increase simulated drawdowns. This was partially accomplished by moving the no-flow boundary of layer 3, thus slightly reducing the simulated thickness of Santa Fe Group deposits. This adjustment resulted in a minor (about 2 feet) increase in drawdown. Adjustments of simulated hydraulic-conductivity values also served to increase drawdowns.

\section{Hydraulic conductivity}

Hydraulic-conductivity values specified for each hydrostratigraphic unit of the Santa Fe Group were changed individually in a trial-and-error manner to minimize the mean absolute difference between model-derived hydraulic heads and 90 measured values (bottom of table 6). Santa Fe Group hydraulicconductivity values for the Las Cruces area (rows 25 and greater, columns 35 and greater, figs. 12-14) were adjusted separately from hydraulic-conductivity values in the rest of the model. Final values of hydraulic conductivity for the area outside of the Las Cruces area were approximately equal to the median values of estimated hydraulic conductivity, and within the Las Cruces area values of hydraulic conductivity were about one-half as large as outside. Although changes in hydraulic conductivity were usually about 10 percent, round numbers were preferred. The final value for the 1 ower hydrostratigraphic unit of the Santa Fe Group ( 13 feet per day) was the same as that used by Frenzel and Kaehler (1990, p. 86) for layer 3 in the Canutillo well field.

Vertical hydraulic conductivity was specified for each hydrostratigraphic unit as a ratio of horizontal hydraulic conductivity. The ratio was adjusted by units of 100 starting with values in the range of 100-500, considering that Frenzel and Kaehler (1990, p. 86) derived a ratio of 200:1. On the basis of the greater lenticularity of the upper and middle hydrostratigraphic units of the Santa Fe Group relative to the lower unit, the lower unit was assumed to be less anisotropic. Upon the last adjustment, the ratios were set to 100:1 for the river alluvium and lower hydrostratigraphic unit of the Santa Fe Group and 500:1 for the upper and middle hydrostratigraphic units of the Santa Fe Group. 


\section{Effects of Existing Withdrawals on Flow in the Rio Grande}

Ground-water withdrawals were derived from three simulated sources: increased depletion of the Rio Grande, salvaged evapotranspiration, and temporary depletion of storage in the aquifer. Part of the depletion of the Rio Grande is due to evapotranspiration from nonirrigated lands. Ground-water withdrawals cause a lowering of the water table and may cause a reduction in evapotranspiration from nonirrigated land. In the following discussion, this reduction is termed "salvaged evapotranspiration" because water derived from this source does not increase the depletion of the Rio Grande. The lowering of the water table also causes decreased flow toward and increased flow from streams, which result in increased depletion of the Rio Grande. The simulated depletion of aquifer storage is eventually replenished by salvaged evapotranspiration or increased depletion of the Rio Grande, or both. However, the time of replenishment may vary greatly depending on the location and continuation of ground-water withdrawal and on aquifer characteristics. Although it is temporary, depletion of aquifer storage is simply referred to as "depletion of storage" in the following discussion. The term "standard" model in the following discussions refers to the final adjusted version described in the section "Description of the model."

The effects of existing nonirrigation withdrawals on flow in the Rio Grande were estimated by comparing the mass balance of the standard model with the mass balance of a simulation that did not include nonirrigation withdrawals. The following is a mass balance for the end of 1985 for the standard model, which includes nonirrigation withdrawals (all units are in cubic feet per second):

\begin{tabular}{lcccccr}
\hline & $\begin{array}{c}\text { Ground- } \\
\text { water } \\
\text { with- } \\
\text { drawals } \\
\text { and } \\
\text { recharge }\end{array}$ & $\begin{array}{c}\text { Evapotrans - } \\
\text { piration }\end{array}$ & $\begin{array}{c}\text { River and } \\
\text { drains }\end{array}$ & $\begin{array}{c}\text { Constant- } \\
\text { head } \\
\text { boundaries }\end{array}$ & $\begin{array}{c}\text { Aquifer } \\
\text { storage }\end{array}$ & Total \\
\hline Inflows & 259.67 & 0 & & & & \\
Outflows & -61.02 & -94.18 & -191.73 & -2.01 & 12.38 & 350.60 \\
Net & 198.65 & -94.18 & -115.22 & .03 & 10.23 & -.49 \\
\hline
\end{tabular}

"Ground-water withdrawals and recharge" are specified values including mountain- and slope-front recharge, net irrigation flux, and nonirrigation withdrawals. "Evapotranspiration" is from nonirrigated lands, a model-derived rate. "River and drains" are seepage to the river and drains combined. "Constant-head boundaries" are model-derived underflows in Selden Canyon, El Paso Narrows, and Fillmore Pass. "Aquifer storage" is a model-derived rate of depletion (inflow) or replacement (outflow) of water in aquifer storage. "Toral" is the summation of the previous five items and "net" is the summation of inflows and outflows. By definition, inflow must equal outflow in a mass balance or, because they are given opposite sign, they must sum to zero. Due to mathematical truncation and rounding errors, there is always a discrepancy between simulated inflows and outflows. The discrepancy (total net) is considered acceptable. 
The following is a mass balance for the end of 1985 for a model that is the same as the standard except that it does not include nonirrigation withdrawals :

\begin{tabular}{|c|c|c|c|c|c|c|}
\hline & $\begin{array}{l}\text { Ground- } \\
\text { water } \\
\text { with- } \\
\text { drawals } \\
\text { and } \\
\text { recharge }\end{array}$ & $\begin{array}{l}\text { Evapotrans - } \\
\text { piration }\end{array}$ & $\begin{array}{l}\text { River and } \\
\text { drains }\end{array}$ & $\begin{array}{c}\text { Constant- } \\
\text { head } \\
\text { boundaries }\end{array}$ & $\begin{array}{l}\text { Aquifer } \\
\text { storage }\end{array}$ & Total \\
\hline $\begin{array}{l}\text { Inflows } \\
\text { Outflows }\end{array}$ & $\begin{array}{c}258.52 \\
0\end{array}$ & $\begin{array}{c}0 \\
-105.20 \\
\end{array}$ & $\begin{array}{r}63.35 \\
-216.88 \\
\end{array}$ & $\begin{array}{r}2.04 \\
-2.07 \\
\end{array}$ & $\begin{array}{r}3.38 \\
-2.92 \\
\end{array}$ & $\begin{array}{r}327.29 \\
-327.07 \\
\end{array}$ \\
\hline Net & 258.52 & -105.20 & -153.53 & -.03 & .46 & .22 \\
\hline $\begin{array}{l}\text { Differ- } \\
\text { ence from } \\
\text { standard } \\
\text { model }\end{array}$ & -59.87 & 11.02 & 38.31 & 0.06 & 9.77 & -.71 \\
\hline
\end{tabular}

The difference is calculated between the net of this model and the net of the standard. The "difference" row in the table shows that the change in "groundwater withdrawals and recharge" (nonirrigation withdrawals) is made up by changes in the other four categories with an accumulated discrepancy of 1.2 percent of the nonirrigation withdrawals ( -0.71 cubic foot per second). Differences were calculated for all time steps in a similar manner and are shown in figure 26A. Figure 26A was constructed so that the differences are represented by the distances between the curves, and the sum of all the positive differences are represented by the uppermost curve, which is the rate of nonirrigation withdrawals. The areas between the curves represent the quantity of water taken from each source. Figure 26A shows that the standard model simulated about two-thirds of nonirrigation withdrawals taken from increased depletion of the Rio Grande, about one-sixth from depletion of aquifer storage, and about one-sixth from salvaged evapotranspiration. In a similar figure, Frenzel and Kaehler (1990, fig. 42A) showed about four-fifths of nonirrigation withdrawals taken from increased depletion of the river. In either simulation most nonirrigation withdrawals are simulated to have been taken from an increase in depletion of the Rio Grande. However, the exact percentage is uncertain and the percentage would be different if the locations of withdrawals were different. 


\section{A. STANDARD MODEL DIFFUSIVITY}

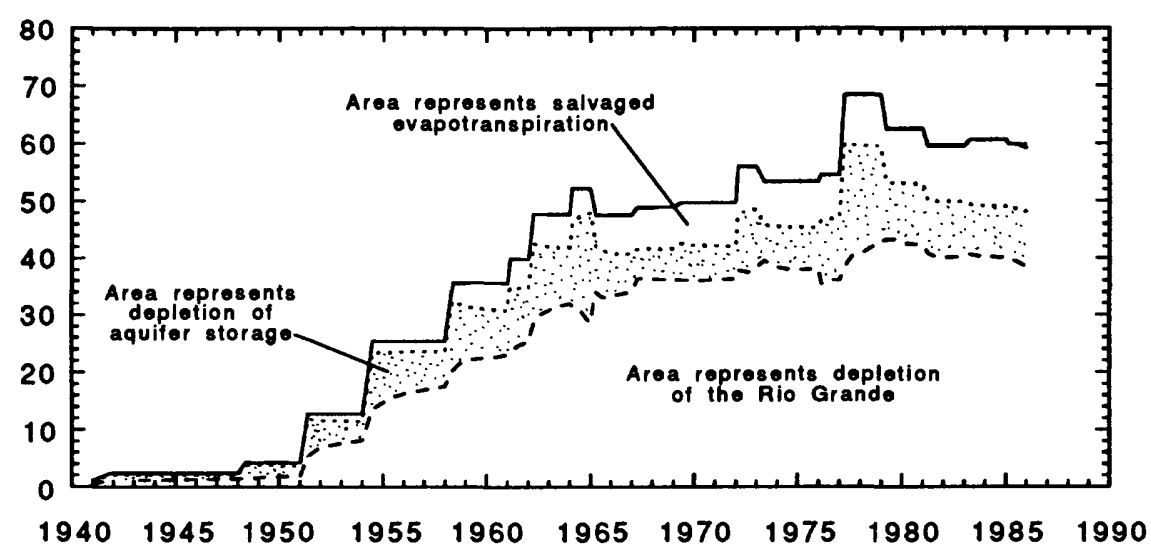

B. DIFFUSIVITY INCREASED BY FACTOR OF 2.25
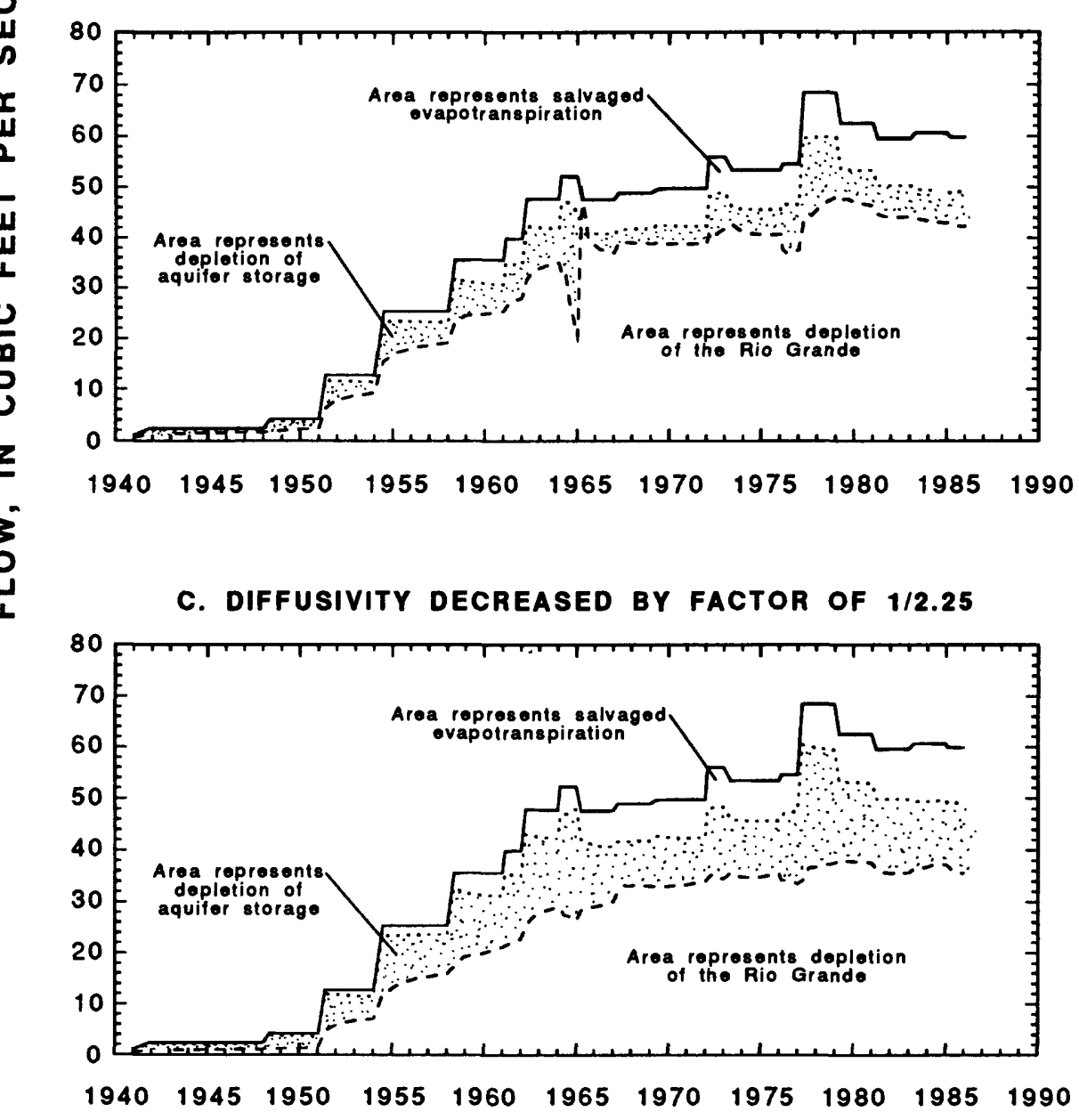

Figure 26.--Effect of changes in diffusivity on the source of water for nonirrigation withdrawals. 
Items in the mass balance of the model can be divided differently to extract additional information. Similar to the mass balance of Frenzel and Kaehler (1990, p. 88), the following table shows the mass balance for the standard model where ground-water withdrawals and recharge, river and drains, and constant-head boundaries have been divided into additional groups. The main components of this mass balance are shown in figure 17. The balance is shown for the initial condition (pre-1915, which is assumed to be steady state), for 1975, and for the end of the simulated time (1985) (a11 units are in cubic feet per second):

\begin{tabular}{|c|c|c|c|}
\hline & $\begin{array}{c}\text { Initial } \\
\text { condition } \\
\text { (steady state) } \\
\end{array}$ & 1975 & $\begin{array}{c}\text { End of } \\
\text { simulated } \\
\text { time } \\
(1985) \\
\end{array}$ \\
\hline \multicolumn{4}{|l|}{ Inflow from: } \\
\hline Net river seepage & 280.53 & 57.83 & 62.13 \\
\hline Net irrigation flux & .00 & 251.13 & 238.81 \\
\hline $\begin{array}{l}\text { Mountain- and slope-front } \\
\text { recharge }\end{array}$ & 17.92 & 19.53 & 19.71 \\
\hline $\begin{array}{l}\text { Underflow in flood-plain } \\
\text { alluvium }\end{array}$ & .35 & 2.04 & 2.04 \\
\hline Total inflows & 298.80 & 330.53 & 322.69 \\
\hline \multicolumn{4}{|l|}{ Outflow to: } \\
\hline Net drain seepage & .00 & 189.89 & 177.35 \\
\hline $\begin{array}{l}\text { Net nonirrigation ground- } \\
\text { water withdrawal }\end{array}$ & .00 & 53.48 & 59.86 \\
\hline $\begin{array}{l}\text { Evapotranspiration from } \\
\text { nonirrigated lands }\end{array}$ & 297.49 & 84.56 & 94.18 \\
\hline $\begin{array}{l}\text { Underflow in flood-plain } \\
\text { alluvium }\end{array}$ & .14 & .96 & .91 \\
\hline $\begin{array}{l}\text { Underflow through Fillmore } \\
\text { Pass }\end{array}$ & .99 & 1.08 & 1.10 \\
\hline Net flow to storage & .00 & .39 & -10.24 \\
\hline Total outflows & 298.62 & 330.36 & 323.16 \\
\hline Difference & .18 & .17 & -.47 \\
\hline Percentage difference & .06 & .05 & .15 \\
\hline
\end{tabular}


The main differences between this mass balance and that of Frenzel and Kaehler (1990, p. 87) are in the net river seepage and in evapotranspiration from nonirrigated lands. Both items were reduced by about 12 percent for steady-state conditions and by about 25 percent for 1975 . Although underflows were increased by as much as 100 percent, they constitute less than 1 percent of the total mass balance. Underflow in Fillmore Pass was not simulated by Frenzel and Kaehler (1990).

Because river and drain seepages are net values, including outflows in the river seepage and inflows in the drain seepages, the inflows and outflows of this table do not compare with those of the above mass-balance table for the standard (the standard includes nonirrigation withdrawals). However, the discrepancy (shown above as "difference") for 1985 is nearly equal to the discrepancy for the standard, as it should be.

With some assumptions, an estimate can be made of the simulated sources of water consumed by evapotranspiration from irrigated lands. Frenzel and Kaehler (1990, p. 96) found that the ultimate sources of nearly 100 percent of water withdrawals that are accounted for by this model were the boundaries-specifically, salvaged evapotranspiration and depletion of the river. Although storage is an important temporary source, the time lag between the depletion and the replenishment of storage is short (perhaps annual) because simulated irrigation activities are all within or very close to the Mesilla Valley boundary along with the river and nonirrigated lands. If it is assumed that evapotranspiration from nonirrigated lands would be approximately equal to the simulated value for steady-state conditions except for human activities, then the difference between steady-state and 1985 evapotranspiration from nonirrigated lands, about 200 (297.49 minus 94.18) cubic feet per second, is equal to the simulated evapotranspiration salvaged by human activities. The human activities that might salvage evapotranspiration mainly have been nonirrigation ground-water withdrawals, and activities associated with irrigation such as drainage, ground-water withdrawals, and replacement of areas of natural evapotranspiration with irrigated cropland. The simulated quantity of evapotranspiration salvaged by nonirrigation withdrawals for 1985 has been shown to be about 10 (11.02) cubic feet per second. The difference, 190 cubic feet per second, constitutes an estimate of salvage by irrigation. The net flow from aquifer storage was approximately 10 ( -10.24 flow to storage) cubic feet per second, most of which ( 9.77 cubic feet per second) was taken by nonirrigation withdrawals, leaving almost no net change in storage caused by irrigation. In the simulation, therefore, all the estimated evapotranspiration from irrigated lands, about 250 cubic feet per second (fig. 8, curve D), came from salvaged evapotranspiration (190 cubic feet per second) and from increased depletion of the Rio Grande (60 cubic feet per second, which is 250 minus 190).

Steady-state (pre-1915) evapotranspiration from nonirrigated lands may be much in error, resulting in large errors in the estimate of evapotranspiration salvaged by irrigation, and hence the estimate of increased depletion of the Rio Grande. For example, whereas a 3-foot error in simulated ground-water altitudes would be acceptable in view of the accuracy of water-level and 1 andsurface altitudes, the same 3-foot error could cause more than a 1-acre-footper-acre error in simulated evapotranspiration. 


\section{Mode1 Evaluation and Sensitivity Tests}

The model's usefulness for projections may be evaluated on the basis of how well it accounts for geologic properties and how well it simulates the historical trends in the hydrologic data. This model accounts for the most recent geologic interpretations, and simulates a decade more of hydrologic data than the Frenzel-Kaehler (1990) model. The model described in this report simulates the hydrologic data reasonably well, as can be seen from comparisons of depletions (figs. 19 and 20), drain flows (fig. 21), and hydraulic heads (figs. 22-25). This does not prove that the model is correct, only that it is reasonably consistent with the data. As is the case for many ground-water models, this model is not unique. Other models also may be reasonably consistent with these data and as more data become available, the models found to be the most consistent with all the data might be retained instead of the others. Hence, as more data become available, this model may be altered or discarded. In the meantime, this model is a reasonable tool for projection.

The adjustment of simulated aquifer characteristics for the Las Cruces area separately from elsewhere improved the overall fit of model-derived to measured hydraulic heads but has some drawbacks. The basinwide adjustment of aquifer characteristics to simulate drawdowns in well fields essentially uses ground-water withdrawals (stress) and drawdowns (response) as a large-scale, long-term aquifer test. The main well fields in the Mesilla Basin are at Cañutillo and Las Cruces. The Cañutillo well field probably could be considered to be part of a larger lower Mesilla Valley field. The adjustment of the Las Cruces area separately implies that the stress-response relation for the Las Cruces area is not considered useful for adjusting the aquifer characteristics of the basin as a whole, leaving the adjustment of Santa $\mathrm{Fe}$ Group aquifer characteristics dependent only on the stress-response relation in the lower Mesilla Valley. As stress-response relations become better known for the West Mesa, the model can be adjusted more accurately for that area.

Sensitivity tests were used to evaluate the model. The sensitivity of the model was tested by setting selected aquifer properties at either 1.5 or 0.67 times the values used in the standard model. Because the main emphasis of model adjustment was directed toward the Santa Fe Group aquifer properties, the criterion for assessing sensitivity was the same as the criterion for adjusting Santa Fe Group properties. The criterion was the mean absolute difference between the model-derived hydraulic heads and the 90 measured hydraulic heads outside of the shallow part of the aquifer in the Mesilla Valley (marked with an asterisk in table 6). The properties tested were specific yield, specific storage, and hydraulic-conductivity values of each hydrostratigraphic unit of the Santa Fe Group. Average differences between model-derived and measured hydraulic heads are listed in table 7 . The results of sensitivity tests are discussed in order of ascending mean absolute differences. Most tests yielded mean absolute differences greater than that of the standard except when storage was set to 1.5 times the standard value, in which case the mean absolute difference was 0.01 foot less than that of the standard. The insensitivity of hydraulic head to changes in storage makes adjustment of storage on the basis of this criterion futile. 
The main conclusion to be drawn from these tests is that the model is not very sensitive to changes in Santa Fe Group aquifer properties even though the sites used in the averages were selected purposefully to increase sensitivity. None of the mean absolute differences are greater than 0.8 foot from the mean absolute of the standard. This insensitivity was found by Frenzel and Kaehler (1990, p. 90 and 93). The implication of this is that model adjustment does not provide a good method of determining Santa Fe Group aquifer properties in the absence of good stress-response data for the West Mesa.

Additional sensitivity tests were conducted to assess the importance of simulated aquifer properties in determining the effects of existing nonirrigation withdrawals on flow in the Rio Grande. Hydraulic diffusivity (defined as transmissivity divided by storage coefficient) was increased by multiplying values of hydraulic conductivity and transmissivity by 1.5 and dividing specific yield and storage coefficients by 1.5 . This increased hydraulic diffusivity by a factor of 2.25. The results are shown in figure $26 \mathrm{~B}$, in which the depletion of aquifer storage is reduced, depletion of the Rio Grande is increased, and salvaged evapotranspiration is nearly unchanged. Reducing hydraulic diffusivity by a factor of $1 / 2.25$ had an opposite effect of similar magnitude (fig. 26C). Figure 26 shows that about 70 percent of 1985 nonirrigation withdrawals were derived from simulated depletion of the Rio Grande with the large diffusivity and about 60 percent were derived with the small diffusivity. As Frenzel and Kaehler (1990, fig. 42) noted, these percentages would be much different if the withdrawals were at some distance from the Mesilla Valley boundary.

Estimates of salvaged evapotranspiration may be much in error. The quantity of water available for salvage is determined by the quantity of evapotranspiration from nonirrigated lands. The complexity of evapotranspiration from nonirrigated lands is not well simulated by the simplistic approach that consists of a constant maximum evapotranspiration rate at land surface and a constant extinction depth with a linear variation between maximum rate and zero at extinction depth. Therefore, the quantity of water that is simulated as being available for salvage may not be reliable. Moreover, no method is known to estimate the possible error.

The estimated depletion of the Rio Grande by nonirrigation withdrawals is not greatly affected by errors in evapotranspiration. Salvaged evapotranspiration by nonirrigation withdrawals is small compared to the estimated increase in depletion of the Rio Grande. For example, if the correct salvage of evapotranspiration by nonirrigation withdrawals were onehalf the estimated rate, increased depletion of the Rio Grande would be about 10 percent greater than the estimated rate. 


\section{SUMMARY AND CONCLUSIONS}

Anticipated ground-water withdrawals in the Mesilla Basin may reduce flow in the Rio Grande and thus reduce the quantity of water available to downstream users. An existing model was revised and extended to assess the effects of existing ground-water withdrawals and to provide a tool for the assessment of the effects of future ground-water withdrawals.

The revised model extended the original 1915-75 simulated historical period an additional 10 years through 1985 and had modifications that were based on recent geological interpretations concerning the depth and stratigraphy of Santa Fe Group deposits. Extension of the simulated period required assembling appropriate data, such as ground-water withdrawals and streamflows, and preparing model input for the additional stress periods. Modifying the model to reflect recent geological interpretations mainly required changing the way that model-layer transmissivity values and verticalconductance values were derived. Whereas the earlier modeling efforts specified hydraulic-conductivity values mainly on the basis of depth, hydraulic-conductivity values in the model described here are specified mainly on the basis of three hydrostratigraphic units of the Santa Fe Group.

The division of the Santa Fe Group into three units facilitates the assignment of aquifer properties on the basis of stratigraphy instead of strictly on the basis of depth. Estimated hydraulic-conductivity values were correlated with hydrostratigraphic units on the basis of the tested intervals. These estimates provided a basis for the initial assignment of aquifer properties. The model was then adjusted with particular attention focused on adjustment of Santa Fe Group aquifer properties. Simulated hydraulicconductivity values after adjustment fell within the middle two quartiles of the estimated values except in the Las Cruces area.

The upper hydrostratigraphic unit is below the water table mainly in the northern part of the basin and is considered the most permeable of the three units because of larger grain size and less cementation. The simulated values of horizontal hydraulic conductivity of the upper unit were 30 feet per day throughout most of the basin and 12 feet per day in the Las Cruces area. The middle hydrostratigraphic unit is considered less permeable than the upper unit, judging by grain size and degree of cementation. The middle unit was divided into two parts, less than 600 feet deep and greater than 600 feet deep, because estimated values of hydraulic conductivity exhibited an inverse correlation with depth. The simulated horizontal hydraulic conductivity of the shallower part of the middle unit was 20 feet per day throughout most of the basin, but was 10 feet per day in the Las Cruces area. The simulated horizontal hydraulic conductivity of the deeper part of the middle unit was 10 feet per day and in the Las Cruces area was 5 feet per day. Although the lower unit consists of more uniform sand, cementation may make its horizontal hydraulic conductivity less than that of the other two units. The simulated horizontal hydraulic conductivity of the lower unit was 13 feet per day. Horizontal-vertical anisotropy is probably greatest in the upper and middle units because of lenticularity. The simulated horizontal-to-vertical anisotropy ratio for the upper and middle units was 500:1 and for the lower unit was $100: 1$. 
The simulated depth of the ground-water system is significantly less than that simulated in the earlier model. The maximum saturated thickness of Santa Fe Group deposits is now considered to be about 2,500 feet, much less than the 3,800 feet that it was previously thought to be.

Except for refinements in the vertical dimension, spacial discretization was the same as that in earlier simulations. In the horizontal direction, the grid had 36 rows and 64 columns and was exactly the same as that of the previous model. In the vertical dimension, layer 5 was discarded because the basin is not as deep as was formerly thought. The thicknesses of layers 1-3 were 300,400 , and 600 feet, respectively, except where layers thinned near the edges of the model. Layer 1 simulated the first 200 feet of basin fill below the water table. Layer boundaries crossed hydrostratigraphic unit boundaries.

Assigned values of hydraulic conductivity and transmissivity were estimated on a different basis than in the earlier model. The hydraulic conductivity (layer 1) or transmissivity (layers 2-4) for a given model block was calculated on the basis of the thickness of each hydrostratigraphic unit represented in the model block.

Several refinements were made on the basis of additional precipitation and crop-acreage data. An evapotranspiration rate was estimated for each year since 1949 on the basis of individual crop acreages. The average estimated evapotranspiration from irrigated lands was revised upward to account for winter transpiration by crops such as alfalfa, pasture, and pecans. This resulted in an average annual estimated evapotranspiration rate of 2.4 acrefeet per acre, almost 10 percent greater than estimated by the previous model. Because the model was adjusted to match measured river depletions, the increase in estimated evapotranspiration from irrigated lands resulted in a decrease in simulated evapotranspiration from nonirrigated lands. The mode1derived value for evapotranspiration from nonirrigated lands was about 1.9 acre-feet per acre of nonirrigated land for 1975 as compared to the value of 2.5 acre-feet per acre of the previous model.

The purpose of this model was to estimate the effects of ground-water withdrawals on flow in the Rio Grande. By comparing the mass balances of simulations with and without nonirrigation ground-water withdrawals, the sources of those withdrawals were estimated. Simulated nonirrigation groundwater withdrawals were estimated to be about two-thirds derived from increased depletion of the Rio Grande. About one-sixth was estimated to have been derived from depletion of aquifer storage and about one-sixth from salvaged evapotranspiration. These proportions are valid for most of the time since the late $1950^{\prime} \mathrm{s}$, after which time simulated nonirrigation withdrawals ranged from about 35 cubic feet per second (1958-60) to about 60 cubic feet per second (1980-85). These results were not very sensitive to changing hydraulic diffusivity by a factor of 2.25 , but would be more sensitive for well fields located more distant from the Mesilla Valley than are existing (1980's) well fields. 


\section{REFERENCES}

Blaney, H.F., and Hanson, E.G., 1965, Consumptive use and water requirements in New Mexico: New Mexico State Engineer Technical Report 32, 82 p.

Conover, C.S., 1954, Ground-water conditions in the Rincon and Mesilla Valleys and adjacent areas in New Mexico: U.S. Geological Survey Water-Supply Paper $1230,200 \mathrm{p}$.

Frenzel, P.F., 1992, Listings of model-input values for the simulation of ground-water flow in the Mesilla Basin, Doña Ana County, New Mexico, and E1 Paso County, Texas: U.S. Geological Survey Open-File Report 91-455, p., 2 diskettes.

Frenzel, P.F., and Kaehler, C.A., 1990, Geohydrology and simulation of groundwater flow in the Mesilla Basin, Doña Ana County, New Mexico, and E1 Paso County, Texas, with a section on Water quality and geochemistry, by S.K. Anderholm: U.S. Geological Survey Open-File Report 88-305, 179 p. (also to be available as U.S. Geological Survey Professional Paper 1407-C [in press]).

Gates, J.S., White, D.E., and Leggat, E.R., 1984, Preliminary study of the aquifers of the lower Mesilla Valley in Texas and New Mexico by model simulation: U.S. Geological Survey Water-Resources Investigations Report $84-4317,21$ p.

Hawley, J.W., 1984, Hydrogeologic cross sections of the Mesilla Bolson area, Dona Ana County, New Mexico, and El Paso County, Texas: Socorro, New Mexico Bureau of Mines and Mineral Resources Open-File Report 190, 10 p.

Hearne, G.A., and Dewey, J.D., 1988, Hydrologic analysis of the Rio Grande basin north of Embudo, New Mexico, Colorado and New Mexico: U.S. Geological Survey Water-Resources Investigations Report 86-4113, 244 p.

Hernandez, J.W., Mapel, C.L., and Enis, P.E., 1987, Community 40-year water plan for the County of Doña Ana, New Mexico, 1980-2030: Las Cruces, New Mexico State University, $73 \mathrm{p}$.

King, W.E., Hawley, J.W., Taylor, A.M., and Wilson, R.P., 1971, Geology and ground-water resources of central and western Doña Ana County, New Mexico: Socorro, New Mexico Bureau of Mines and Mineral Resources Hydrologic Report 1, 64 p.

Lansford, R.R., Ben-David, Shaul, Gebhard, T.G., Jr., Brutsaert, W.F., and Creel, B.J., 1974, An analytical interdisciplinary evaluation of the utilization of the water resources of the Rio Grande in New Mexico, lower Rio Grande region: Las Cruces, New Mexico Water Resources Research Institute Report 024, 109 p.

Lansford, R.R., Sorensen, E.F., Gollehon, N.R., Fisburn, M., Loslebon, L., Creel, B.J., and West, F.G., 1980, Sources of irrigation water and irrigated and dry cropland acreages in New Mexico, by county, 1974-1979: Las Cruces, New Mexico State University Agricultural Experiment Station Research Report 422, 39 p. 


\section{REFERENCES - - Continued}

Leggat, E.R., Lowry, M.E., and Hood, J.W., 1962, Ground-water resources of the lower Mesilla Valley, Texas and New Mexico: Texas Water Commission Bulletin 6203, 191 p.

Lizarraga, S.P., 1978, A non-1inear lumped-parameter model for the Mesilla Valley, New Mexico: Socorro, New Mexico Institute of Mining and Technology, unpublished M.S. thesis, $43 \mathrm{p}$.

Lohman, S.W., 1972, Ground-water hydraulics: U.S. Geological Survey Professional Paper 708, 80 p.

McDonald, M.G., and Harbaugh, A.W., 1988, A modular three-dimensional finitedifference ground-water flow model, in Modeling techniques: Techniques of Water-Resources Investigations of the U.S. Geological Survey, book 6, chap. Al, various pagination.

Miller, R.S., 1988, User's guide for RIV2--A package for routing and accounting of river discharge for a modular, three-dimensional, finitedifference, ground-water flow model: U.S. Geological Survey Open-File Report 88-345, $33 \mathrm{p}$.

Myers, R.G., and Orr, B.R., 1985, Geohydrology of the aquifer in the Santa Fe Group, northern west mesa of the Mesilla Basin near Las Cruces, New Mexico: U.S. Geological Survey Water-Resources Investigations Report 84$4190,37 \mathrm{p}$.

Nickerson, E.L., 1989, Aquifer tests in the flood-plain alluvium and Santa Fe Group at the Rio Grande near Cañutillo, E1 Paso County, Texas: U.S. Geological Survey Water-Resources Investigations Report 89-4011, $30 \mathrm{p}$.

Peterson, D.M., Khaleel, Raz, and Hawley, J.W., 1984, Quasi three-dimensional modeling of groundwater flow in the Mesilla Bolson, New Mexico and Texas: Las Cruces, New Mexico Water Resources Research Institute Technical Completion Report, Project No. 1-3-45645, October 1984, 185 p.

Richardson, G.L., Gebhard, T.G., and Brutsaert, W.F., 1972, Water-table investigation in the Mesilla Valley: Las Cruces, New Mexico State University Engineering Experiment Station Technical Report 76, 206 p.

Seager, W.R., Hawley, J.W., Kottlowski, F.E., and Kelley, S.A., 1987, Geology of east half of Las Cruces and northeast E1 Paso 1-degree by 2-degree sheets, New Mexico: Socorro, New Mexico Bureau of Mines and Mineral Resources Geologic Map 57, scale 1:124,000, 2 sheets.

Slichter, C.S., 1905, Observations on the ground waters of the Rio Grande valley: U.S. Geological Survey Water-Supply Paper 141, 83 p.

Sorensen, E.F., 1977, Water use by categories in New Mexico counties and river basins, and irrigated and dry cropland acreage in 1975: New Mexico State Engineer Technical Report 41, 34 p. 


\section{REFERENCES - - Concluded}

Spiegel, Zane, 1958, Ground-water trends in New Mexico: New Mexico Professional Engineer, March, pt. 1, p. 8-12, and April, pt. 2, p. 8-11.

Taylor, A.M., 1967, Geohydrologic investigations in the Mesi11a Va11ey, New Mexico: Las Cruces, New Mexico State University, unpublished M.S. thesis, $130 \mathrm{p}$.

U.S. Department of Commerce, Bureau of the Census, 1952, Census of population, 1950 , v. II, Characteristics of the population: pt. 31, New Mexico, $138 \mathrm{p}$.

1982, Census of population, 1980, v. 1, Characteristics of the population, Chapter A, Number of inhabitants: pt. 33, New Mexico, 37 p.

Wilson, C.A., and White, R.R., 1984, Geohydrology of the central Mesilla Valley, Doña Ana County, New Mexico: U.S. Geological Survey WaterResources Investigations 82-555, 144 p.

Wilson, C.A., White, R.R., Orr, B.R., and Roybal, R.G., 1981, Water resources of the Rincon and Mesilla Valleys and adjacent areas, New Mexico: New Mexico State Engineer Technical Report 43, 514 p. 


\section{Table 1.--Estimated values of hydraulic conductivity of the Santa Fe Group}

[Open interval is the depth below land surface of the interval of hydraulic connection to the aquifer. Both intervals of well screen and open hole

are included. $\mathrm{K}$ is the estimated hydraulic conductivity. Adjusted interval is the open interval below the water table. No adjustment was made for wells in the valley where the water table is relatively shallow (about 15 feet). Depth is the approximate depth from the water table to the middle of the open interval. Depth, in reference to plates 16 and 17 of J.W. Hawley and R.P. Lozinsky (New Mexico Bureau of Mines and Mineral Resources, written commun., 1988), was used to determine the hydrostratigraphic unit. Reference A is Nickerson (1989,

p. 19 and 24), B is Myers and Orr (1985, p. 16), and C is

Leggat and others (1962, p. 32; table 1). If no reference is shown, values are from Frenzel and Kaehler (1990, table 1)]

\begin{tabular}{|c|c|c|c|c|c|c|c|}
\hline Latitude & Longitude & Well number & $\begin{array}{c}\text { Open } \\
\text { interval } \\
\text { (feet) }\end{array}$ & $\begin{array}{c}\mathrm{K} \\
\text { (feet } \\
\text { per } \\
\text { day) }\end{array}$ & $\begin{array}{c}\text { Ad justed } \\
\text { interval } \\
\text { (feet) }\end{array}$ & $\begin{array}{c}\text { Depth } \\
\text { (feet) }\end{array}$ & $\begin{array}{c}\text { Refer- } \\
\text { ence }\end{array}$ \\
\hline
\end{tabular}

Upper hydrostratigraphic unit of the Santa Fe Group

\begin{tabular}{|c|c|c|c|c|c|c|}
\hline $32^{\circ} 22^{\prime} 23^{\prime \prime}$ & $106^{\circ} 49^{\prime} 16^{\prime \prime}$ & 22S.1E.22.444 & $252-273$ & 2 & & 262 \\
\hline $32^{\circ} 09^{\prime} 42^{\prime \prime}$ & $106^{\circ} 44^{\prime} 17^{\prime \prime}$ & $25 \mathrm{~S} .2 \mathrm{E} .4 .141$ & $242-262$ & 5 & & 252 \\
\hline $32^{\circ} 19^{\prime} 17^{\prime \prime}$ & $106^{\circ} 48^{\prime} 20^{\prime \prime}$ & $23 \mathrm{~S} .1 \mathrm{E} .11 .214$ & $384-404$ & 7 & & 394 \\
\hline $32^{\circ} 19^{\prime} 17^{\prime \prime}$ & $106^{\circ} 48^{\prime} 20^{\prime \prime}$ & $23 \mathrm{~S} .1 \mathrm{E} .11 .214$ & $510-530$ & 7 & & 520 \\
\hline $32^{\circ} 10^{\prime} 47^{\prime \prime}$ & $106^{\circ} 43^{\prime} 26^{\prime \prime}$ & 24S.2E.36.131 & $392-412$ & 8 & & 402 \\
\hline $32^{\circ} 18^{\prime} 32^{\prime \prime}$ & $106^{\circ} 45^{\prime} 13^{\prime \prime}$ & 23S. 2E.17.243 & $410-700$ & 10 & $280-570$ & \\
\hline $32^{\circ} 18^{\prime} 56^{\prime \prime}$ & $106^{\circ} 45^{\prime} 28^{\prime \prime}$ & $23 \mathrm{~S} .2 \mathrm{E} .8 .433$ & $430-716$ & 12 & $280-566$ & 423 \\
\hline $32^{\circ} 18^{\prime} 19^{\prime \prime}$ & $106^{\circ} 44^{\prime} 52^{\prime \prime}$ & 23S.2E.16.314 & $381-591$ & 13 & $231-441$ & 336 \\
\hline $32^{\circ} 22^{\prime} 23^{\prime \prime}$ & $106^{\circ} 49^{\prime} 16^{\prime \prime}$ & 22S.1E.22.444 & $504-525$ & 18 & & 514 \\
\hline $32^{\circ} 18^{\prime} 30^{\prime \prime}$ & $106^{\circ} 47^{\prime} 30^{\prime \prime}$ & 23S.1E.13.411B & 429-629 & 19 & & 529 \\
\hline $32^{\circ} 20^{\prime} 09^{\prime \prime}$ & $106^{\circ} 45^{\prime} 23^{\prime \prime}$ & 23 S. 2E. 5.321 & $392-620$ & 20 & $212-440$ & 326 \\
\hline $32^{\circ} 19^{\prime} 46^{\prime \prime}$ & $106^{\circ} 50^{\prime} 28^{\prime \prime}$ & 23 S.1E.4.434 & $335-355$ & 25 & & 345 \\
\hline $32^{\circ} 16^{\prime} 42^{\prime \prime}$ & $106^{\circ} 46^{\prime} 04^{\prime \prime}$ & $23 \mathrm{~S} .2 \mathrm{E} .30 .243 \mathrm{~A}$ & $205-225$ & 26 & & 215 \\
\hline $32^{\circ} 19^{\prime} 14^{\prime \prime}$ & $106^{\circ} 46^{\prime} 33^{\prime \prime}$ & 23S. 2E. 7.122 & $213-360$ & 26 & $153-300$ & 226 \\
\hline $32^{\circ} 13^{\prime} 08^{\prime \prime}$ & $106^{\circ} 45^{\prime} 38^{\prime \prime}$ & $24 \mathrm{~S} .2 \mathrm{E} .17 .322$ & $180-464$ & 38 & & 322 \\
\hline $32^{\circ} 19^{\prime} 14^{\prime \prime}$ & $106^{\circ} 46^{\prime} 25^{\prime \prime}$ & $23 \mathrm{~S} .2 \mathrm{E} .7 .411$ & $281-381$ & 44 & $221-321$ & 271 \\
\hline $32^{\circ} 14^{\prime} 10^{\prime \prime}$ & $106^{\circ} 46^{\prime} 27^{\prime \prime}$ & 24S.2E.7.231 & $170-460$ & 47 & & 315 \\
\hline $32^{\circ} 16^{\prime} 42^{\prime \prime}$ & $106^{\circ} 46^{\prime} 04^{\prime \prime}$ & 23S.2E.30.243A & $310-330$ & 47 & & 320 \\
\hline $32^{\circ} 16^{\prime} 42^{\prime \prime}$ & $106^{\circ} 46^{\prime} 04^{\prime \prime}$ & $23 \mathrm{~S} .2 \mathrm{E} .30 .243 \mathrm{~A}$ & $430-450$ & 48 & & 440 \\
\hline $32^{\circ} 16^{\prime} 28^{\prime \prime}$ & $106^{\circ} 45^{\prime} 58^{\prime \prime}$ & 23S.2E.29:331 & $243-458$ & 50 & & 350 \\
\hline $32^{\circ} 19^{\prime} 17^{\prime \prime}$ & $106^{\circ} 48^{\prime} 20^{\prime \prime}$ & 23S.1E.11.214A & $465-485$ & 55 & & 475 \\
\hline $32^{\circ} 13^{\prime} 35^{\prime \prime}$ & $106^{\circ} 47^{\prime} 21^{\prime \prime}$ & 24S.1E.13.221A & $140-370$ & 60 & & 255 \\
\hline $32^{\circ} 12^{\prime} 36^{\prime \prime}$ & $106^{\circ} 44^{\prime} 45^{\prime \prime}$ & 24 S. 2E. 21.123 & $170-480$ & 68 & & 32 \\
\hline
\end{tabular}


Table 1.--Estimated values of hydraulic conductivity of the Santa Fe Group--Continued

\begin{tabular}{|c|c|c|c|c|c|c|c|}
\hline Latitude & Longitude & Wel1 number & $\begin{array}{c}\text { Open } \\
\text { interval } \\
\text { (feet) }\end{array}$ & $\begin{array}{c}\mathrm{K} \\
\text { (feet } \\
\text { per } \\
\text { day) }\end{array}$ & $\begin{array}{c}\text { Ad justed } \\
\text { interval } \\
\text { (feet) }\end{array}$ & $\begin{array}{l}\text { Depth } \\
\text { (feet) }\end{array}$ & $\begin{array}{c}\text { Refer- } \\
\text { ence }\end{array}$ \\
\hline
\end{tabular}

Middle hydrostratigraphic unit of the Santa Fe Group (less than 600 feet below the water table)

\begin{tabular}{|c|c|c|c|c|c|c|}
\hline $32^{\circ} 07^{\prime} 37^{\prime \prime}$ & $106^{\circ} 39^{\prime} 57^{\prime \prime}$ & $25 \mathrm{~S} .3 \mathrm{E} .17 .111 \mathrm{~A}$ & $437-457$ & 2 & & 447 \\
\hline $32^{\circ} 03^{\prime} 37^{\prime \prime}$ & $106^{\circ} 39^{\prime} 13^{\prime \prime}$ & $26 \mathrm{~S} .3 \mathrm{E} .8 .143$ & $400-420$ & 3 & & 410 \\
\hline $32^{\circ} 09^{\prime} 42^{\prime \prime}$ & $106^{\circ} 44^{\prime} 17^{\prime \prime}$ & $25 \mathrm{~S} .2 \mathrm{E} .4 .141$ & $505-525$ & 5 & & 515 \\
\hline $32^{\circ} 06^{\prime} 29^{\prime \prime}$ & $106^{\circ} 42^{\prime} 51^{\prime \prime}$ & 25S.2E. 26.114 & $251-272$ & 7 & & 262 \\
\hline $32^{\circ} 02^{\prime} 45^{\prime \prime}$ & $106^{\circ} 37^{\prime} 47^{\prime \prime}$ & $26 \mathrm{~S} .3 \mathrm{E} .15 .322$ & $310-330$ & 10 & & 320 \\
\hline $31^{\circ} 56^{\prime} 25^{\prime \prime}$ & $106^{\circ} 39^{\prime} 17^{\prime \prime}$ & 27 S. 3E. 20.432 & $195-215$ & 12 & & 205 \\
\hline $32^{\circ} 10^{\prime} 47^{\prime \prime}$ & $106^{\circ} 43^{\prime} 26^{\prime \prime}$ & 24 S. 2E. 36.131 & $507-527$ & 12 & & 517 \\
\hline $32^{\circ} 06^{\prime} 29^{\prime \prime}$ & $106^{\circ} 42^{\prime} 51^{\prime \prime}$ & 25S.2E.26.114 & $503-524$ & 16 & & 14 \\
\hline $31^{\circ} 56^{\prime} 25^{\prime \prime}$ & $106^{\circ} 39^{\prime} 17^{\prime \prime}$ & 27S. 3E. 20.432 & $450-470$ & 18 & & 460 \\
\hline $32^{\circ} 00^{\prime} 54^{\prime \prime}$ & $106^{\circ} 53^{\prime} 39^{\prime \prime}$ & $26 \mathrm{~S} .1 \mathrm{~W} .25 .414$ & $443-563$ & 24 & $53-173$ & 113 \\
\hline $31^{\circ} 51^{\prime} 11^{\prime \prime}$ & $106^{\circ} 39^{\prime} 18^{\prime \prime}$ & 28S.3E. 20.432 & $163-320$ & 24 & $53-210$ & 132 \\
\hline $31^{\circ} 50^{\prime} 50^{\prime \prime}$ & $106^{\circ} 38^{\prime} 49^{\prime \prime}$ & $28 \mathrm{~S} .3 \mathrm{E} .28 .114$ & $240-350$ & 25 & $110-220$ & 165 \\
\hline $31^{\circ} 50 \cdot 46^{\prime \prime}$ & $106^{\circ} 39^{\prime} 29^{\prime \prime}$ & 28S.3E.29.231 & $201-350$ & 26 & $71-220$ & 146 \\
\hline $31^{\circ} 57 \cdot 10^{\prime \prime}$ & $106^{\circ} 36^{\prime} 23^{\prime \prime}$ & $\mathrm{JL}-49-04-423$ & $97-200$ & 26 & & 148 \\
\hline $32^{\circ} 04^{\prime} 14^{\prime \prime}$ & $106^{\circ} 39^{\prime} 58^{\prime \prime}$ & 26 S. 3E. 6.442 & $307-597$ & 35 & & 452 \\
\hline $32^{\circ} 13^{\prime} 24^{\prime \prime}$ & $106^{\circ} 43^{\prime} 26^{\prime \prime}$ & $24 \mathrm{~S} .2 \mathrm{E} .15 .231 \mathrm{~A}$ & $463-484$ & 36 & & 74 \\
\hline $32^{\circ} 13^{\prime} 14^{\prime \prime}$ & $106^{\circ} 45^{\prime} 10^{\prime \prime}$ & 24 S.2E.17.423A & $310-680$ & 41 & & 495 \\
\hline $32^{\circ} 05^{\prime} 40^{\prime \prime}$ & $106^{\circ} 36^{\prime} 40^{\prime \prime}$ & 25 S. $3 E .28 .434$ & $225-245$ & 45 & & 235 \\
\hline $31^{\circ} 50^{\prime} 44^{\prime \prime}$ & $106^{\circ} 38^{\prime} 08^{\prime \prime}$ & 28S.3E.28.241 & $135-285$ & 51 & $75-225$ & 150 \\
\hline $32^{\circ} 02^{\prime} 45^{\prime \prime}$ & $106^{\circ} 37^{\prime} 47^{\prime \prime}$ & $26 \mathrm{~S} .3 \mathrm{E} .15 .322$ & $565-585$ & 100 & & 7 \\
\hline
\end{tabular}

Middle hydrostratigraphic unit of the Santa Fe Group (more than 600 feet below the water table)

$\begin{array}{lllllr}32^{\circ} 03^{\prime} 37^{\prime \prime} & 106^{\circ} 39^{\prime} 13^{\prime \prime} & 26 \mathrm{~S} .3 \mathrm{E} .8 .143 & 945-965 & 1 & 955 \\ 32^{\circ} 09^{\prime} 42^{\prime \prime} & 106^{\circ} 44^{\prime} 17^{\prime \prime} & 25 \mathrm{~S} .2 \mathrm{E} .4 .141 & 660-680 & 2 & 670 \\ 32^{\circ} 07^{\prime} 37^{\prime \prime} & 106^{\circ} 39^{\prime} 57^{\prime \prime} & 25 \mathrm{~S} .3 \mathrm{E} .17 .111 \mathrm{~A} & 675-685 & 2 & 680 \\ 32^{\circ} 02^{\prime} 45^{\prime \prime} & 106^{\circ} 37^{\prime} 47^{\prime \prime} & 26 \mathrm{~S} .3 \mathrm{E} .15 .322 & 820-840 & 3 & 682 \\ 32^{\circ} 22^{\prime} 23^{\prime \prime} & 106^{\circ} 49^{\prime} 16^{\prime \prime} & 22 \mathrm{~S} .1 \mathrm{E} .22 .444 & 672-693 & 4 & 660 \\ & & & & & 1,180 \\ 32^{\circ} 16^{\prime} 42^{\prime \prime} & 106^{\circ} 46^{\prime} 04^{\prime \prime} & 23 \mathrm{~S} .2 \mathrm{E} .30 .243 \mathrm{~A} & 650-670 & 5 & 1,210 \\ 32^{\circ} 02^{\prime} 45^{\prime \prime} & 106^{\circ} 37^{\prime} 47^{\prime \prime} & 26 \mathrm{~S} .3 \mathrm{E} .15 .322 & 1,170-1,190 & 5 & 662 \\ 32^{\circ} 05^{\prime} 40^{\prime \prime} & 106^{\circ} 36^{\prime} 40^{\prime \prime} & 25 \mathrm{~S} .3 \mathrm{E} .28 .434 & 1,200-1,220 & 6 & 650 \\ 32^{\circ} 06^{\prime} 29^{\prime \prime} & 106^{\circ} 42^{\prime} 51^{\prime \prime} & 25 \mathrm{~S} .2 \mathrm{E} .26 .114 & 651-672 & 8 & \\ 32^{\circ} 19^{\prime} 17^{\prime \prime} & 106^{\circ} 48^{\prime} 20^{\prime \prime} & 23 \mathrm{~S} .1 \mathrm{E} .11 .214 & 640-660 & 9 & \end{array}$


Table 1.--Estimated values of hydraulic conductivity of the Santa Fe Group--Concluded

\begin{tabular}{|c|c|c|c|c|c|c|c|}
\hline Latitude & Longitude & We11 number & $\begin{array}{l}\text { Open } \\
\text { interval } \\
\text { (feet) }\end{array}$ & $\begin{array}{l}\mathrm{K} \\
\text { (feet } \\
\text { per } \\
\text { day) }\end{array}$ & $\begin{array}{l}\text { Ad justed } \\
\text { interval } \\
\text { (feet) }\end{array}$ & $\begin{array}{l}\text { Depth } \\
\text { (feet) }\end{array}$ & $\begin{array}{l}\text { Refer- } \\
\text { ence }\end{array}$ \\
\hline $\begin{array}{l}32^{\circ} 08^{\prime} 26^{\prime \prime} \\
32^{\circ} 02^{\prime} 45^{\prime \prime} \\
31^{\circ} 56^{\prime} 25^{\prime \prime} \\
32^{\circ} 05^{\prime} 40^{\prime \prime} \\
32^{\circ} 16^{\prime} 40^{\prime \prime}\end{array}$ & $\begin{array}{l}106^{\circ} 51^{\prime} 12^{\prime \prime} \\
106^{\circ} 37^{\prime} 47^{\prime \prime} \\
106^{\circ} 39^{\prime} 17^{\prime \prime} \\
106^{\circ} 36^{\prime} 40^{\prime \prime} \\
106^{\circ} 52^{\prime} 20^{\prime \prime}\end{array}$ & $\begin{array}{l}25 \mathrm{~S} .1 \mathrm{E} .16 .114 \\
26 \mathrm{~S} .3 \mathrm{E} .15 .322 \\
27 \mathrm{~S} .3 \mathrm{E} .20 \cdot 432 \\
25 \mathrm{~S} .3 \mathrm{E} .28 .434 \\
23 \mathrm{~S} .1 \mathrm{E} .30 \cdot 422\end{array}$ & $\begin{array}{c}600-1,650 \\
1,050-1,070 \\
640-660 \\
730-750 \\
720-1,220\end{array}$ & $\begin{array}{l}12 \\
13 \\
14 \\
14 \\
14\end{array}$ & $250-1,300$ & $\begin{array}{r}875 \\
1,060 \\
650 \\
740 \\
650\end{array}$ & B \\
\hline $\begin{array}{l}32^{\circ} 18^{\prime} 30^{\prime \prime} \\
32^{\circ} 18^{\prime} 30^{\prime \prime} \\
32^{\circ} 02^{\prime} 45^{\prime \prime}\end{array}$ & $\begin{array}{l}106^{\circ} 47^{\prime} 30^{\prime \prime} \\
106^{\circ} 47^{\prime} 30^{\prime \prime} \\
106^{\circ} 37^{\prime} 47^{\prime \prime}\end{array}$ & $\begin{array}{l}23 \mathrm{~S} .1 \mathrm{E} .13 .411 \\
23 \mathrm{~S} .1 \mathrm{E} .13 .411 \\
26 \mathrm{~S} .3 \mathrm{E} .15 .322\end{array}$ & $\begin{array}{l}600-620 \\
961-981 \\
670-690\end{array}$ & $\begin{array}{l}19 \\
19 \\
29\end{array}$ & & $\begin{array}{l}610 \\
971 \\
680\end{array}$ & \\
\hline \multicolumn{8}{|c|}{ Lower hydrostratigraphic unit of the Santa Fe Group } \\
\hline $\begin{array}{l}31^{\circ} 47^{\prime} 24^{\prime \prime} \\
32^{\circ} 18^{\prime} 30^{\prime \prime} \\
32^{\circ} 03^{\prime} 37^{\prime \prime} \\
32^{\circ} 18^{\prime} 30^{\prime \prime} \\
31^{\circ} 47^{\prime} 24^{\prime \prime}\end{array}$ & $\begin{array}{l}106^{\circ} 35^{\prime} 07^{\prime \prime} \\
106^{\circ} 47^{\prime} 30^{\prime \prime} \\
106^{\circ} 39^{\prime} 13^{\prime \prime} \\
106^{\circ} 47^{\prime} 30^{\prime \prime} \\
106^{\circ} 35^{\prime} 07^{\prime \prime}\end{array}$ & $\begin{array}{l}29 \mathrm{~S} .3 \mathrm{E} .13 .223 \\
23 \mathrm{~S} .1 \mathrm{E} .13 .411 \\
26 \mathrm{~S} .3 \mathrm{E} .8 .143 \\
23 \mathrm{~S} .1 \mathrm{E} .13 .411 \\
29 \mathrm{~S} .3 \mathrm{E} .13 .223\end{array}$ & $\begin{array}{l}300-320 \\
1,448-1,468 \\
1,660-1,680 \\
1,260-1,280 \\
390-410\end{array}$ & $\begin{array}{l}1 \\
1 \\
2 \\
3 \\
8\end{array}$ & $\begin{array}{l}120-140 \\
210-230\end{array}$ & $\begin{array}{r}130 \\
1,458 \\
1,670 \\
1,270 \\
220\end{array}$ & \\
\hline $\begin{array}{l}31^{\circ} 57^{\prime} 17^{\prime \prime} \\
31^{\circ} 57^{\prime} 33^{\prime \prime} \\
31^{\circ} 58^{\prime} 07^{\prime \prime} \\
31^{\circ} 57^{\prime} 17^{\prime \prime} \\
31^{\circ} 57^{\prime} 03^{\prime \prime}\end{array}$ & $\begin{array}{l}106^{\circ} 36^{\prime} 22^{\prime \prime} \\
106^{\circ} 36^{\prime} 45^{\prime \prime} \\
106^{\circ} 36^{\prime} 29^{\prime \prime} \\
106^{\circ} 36^{\prime} 40^{\prime \prime} \\
106^{\circ} 36^{\prime} 43^{\prime \prime}\end{array}$ & $\begin{array}{l}\mathrm{JL}-49-04-401 \\
\mathrm{JL}-49-04-106 \\
\mathrm{JL}-49-04-105 \\
\mathrm{JL}-49-04-419 \\
\mathrm{JL}-49-04-402\end{array}$ & $\begin{array}{l}510-900 \\
544-1,090 \\
544-950 \\
585-1,050 \\
586-1,060\end{array}$ & $\begin{array}{l}11 \\
14 \\
16 \\
17 \\
17\end{array}$ & & $\begin{array}{l}705 \\
817 \\
747 \\
817 \\
823\end{array}$ & $\begin{array}{l}\text { A } \\
\text { C } \\
\text { C } \\
\text { C } \\
\text { C }\end{array}$ \\
\hline $\begin{array}{l}31^{\circ} 57^{\prime} 58^{\prime \prime} \\
32^{\circ} 03^{\prime} 37^{\prime \prime}\end{array}$ & $\begin{array}{l}106^{\circ} 36^{\prime} 57^{\prime \prime} \\
106^{\circ} 39^{\prime} 13^{\prime \prime}\end{array}$ & $\begin{array}{l}\mathrm{JL}-49-04-104 \\
26 \mathrm{~S} .3 \mathrm{E} .8 .143\end{array}$ & $\begin{array}{r}650-1,150 \\
1410-1,430\end{array}$ & $\begin{array}{l}20 \\
34\end{array}$ & & $\begin{array}{r}900 \\
1,420\end{array}$ & C \\
\hline
\end{tabular}


Table 2.--Values used for estimating net irrigation flux

\section{EXPLANATION}

Adjusted net diversion is the total diverted water at Leasburg and Mesilla minus water returned to the river or drains (net diversion) minus estimated evaporation from canals (4,000 acre-feet).

Growing-season precipitation is mean precipitation during April through October at all reporting sites.

Annual precipitation is the mean of the year's precipitation at all reporting sites.

Agricultural effective precipitation is 0.9 times growing-season precipitation, times the total irrigated acreage, divided by 12 . These multipliers are the same as those of Frenzel and Kaehler (1990, p. 37).

Nonagricultural effective precipitation is 0.2 times the annual precipitation, times the nonirrigated part of the valley, divided by 12 .

Project-irrigated acreage is the acreage irrigated in the Bureau of Reclamation project (sources of irrigated acreage: 1915-29, Frenzel and Kaehler, 1990, fig. 6; 1930-46, Conover, 1954, table 4; 1947-75, Wilson and others, 1981, table 10; 1976-78, R.K. Patterson, U.S. Bureau of

Reclamation, written commun., 1983; 1979, Angel Colon, E1 Paso County Water Improvement District, written commun., 1988; 1980-85, Edd Fifer, E1 Paso County Water Improvement District, written commun., 1988, for the Texas part of the Mesilla Valley, and Elephant Butte Irrigation District records, Bureau of Reclamation Form 7-2045 for the New Mexico part).

Total irrigated acreage is project-irrigated acreage plus 3,000 acres for 1958 and later.

Evapotranspiration is evapotranspiration rate times total irrigated acreage.

Net irrigation flux (curve $E$ of fig. 8) is adjusted net diversion (curve A of fig. 8) plus agricultural effective precipitation (curve B of fig. 8), plus nonagricultural effective precipitation (curve $C$ of fig. 8), minus evapotranspiration (curve D of fig. 8).

Model flux is net irrigation flux divided by the area of the model blocks, in acres, that simulate net irrigation flux (fig. 17). The area of net irrigation flux was 114,000 acres for stress periods 2-22. For stress period 1 , the area of net irrigation flux was divided into two parts. The part north of the State line at Anthony was assigned a net flux of 0.68 foot to account for irrigation (Frenzel and Kaehler, 1990, p. 66), and the part south of the State line was assigned a net flux of 0.30 foot to account for precipitation on nonirrigated acreage.

Values in this table for stress periods 1 and 2 are approximate average values. Evapotranspiration rates for years before 1949 are average values, as is growing-season precipitation for years before 1931. 


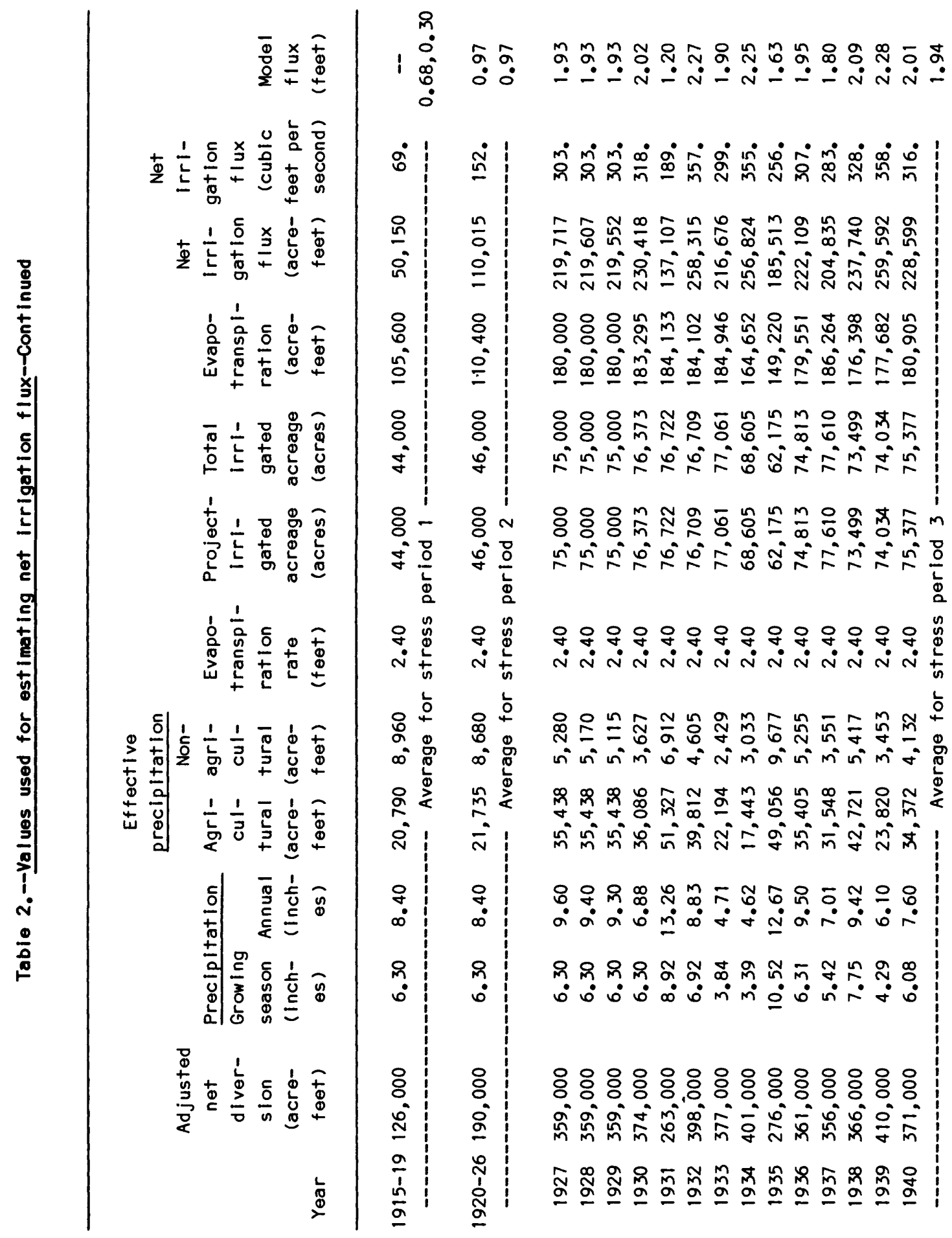




\begin{tabular}{|c|c|c|c|c|}
\hline $\begin{array}{l}\overline{\mathrm{g}} \\
\frac{\mathrm{o}}{2}\end{array}$ & 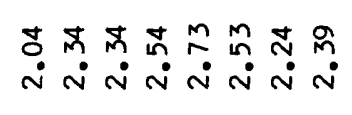 & 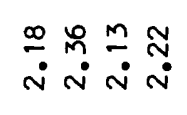 & 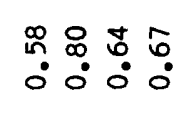 & 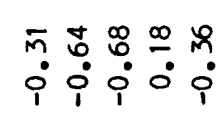 \\
\hline 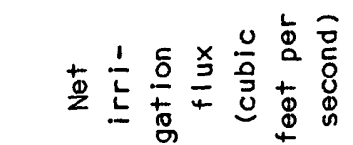 & $\dot{\bar{N}}$ & 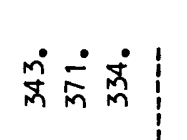 & $\dot{\sigma} \dot{g} \dot{0}$ & 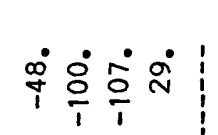 \\
\hline 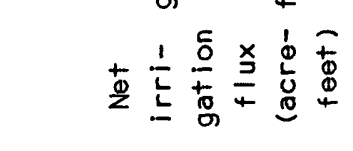 & 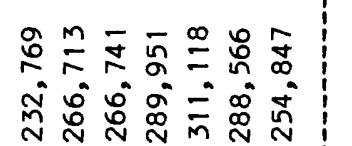 & 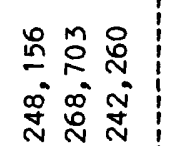 & 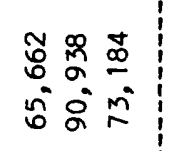 & 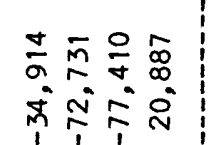 \\
\hline 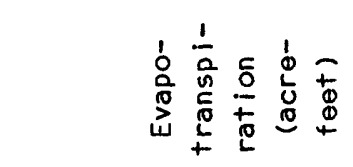 & 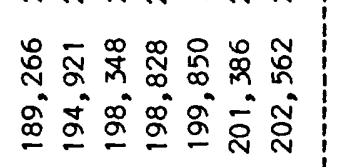 & 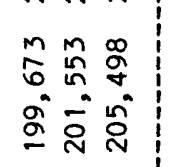 & 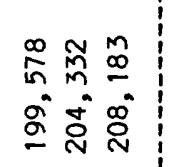 & 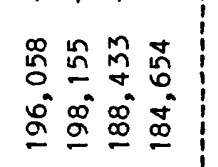 \\
\hline$\overline{0}$ & 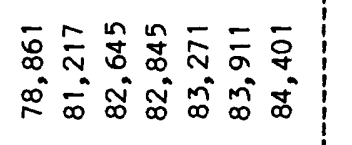 & 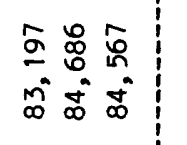 & 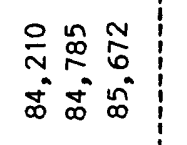 & 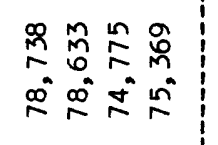 \\
\hline $\begin{array}{l}1 \\
\frac{1}{0} \\
0.0 \\
0 \\
0 \\
\frac{2}{2}\end{array}$ & 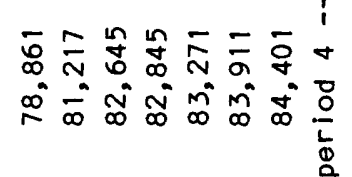 & 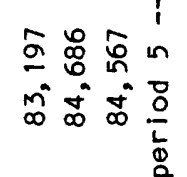 & 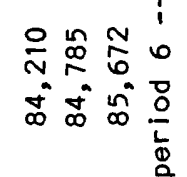 & 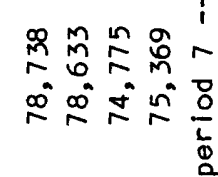 \\
\hline 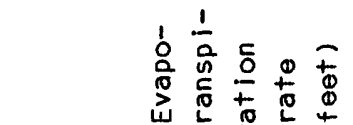 & 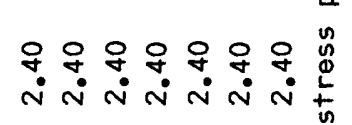 & 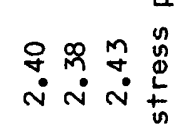 & 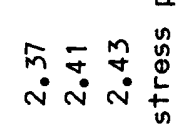 & 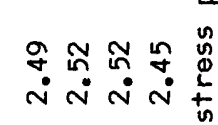 \\
\hline 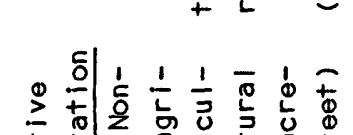 & 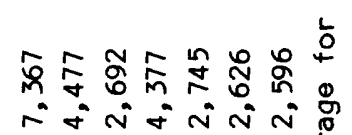 & 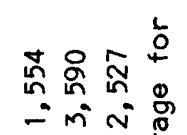 & 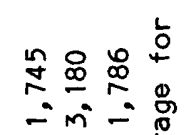 & 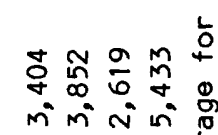 \\
\hline 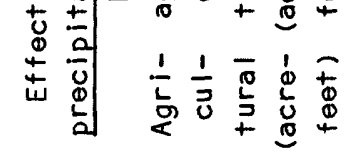 & 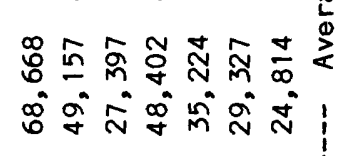 & 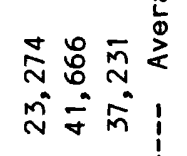 & 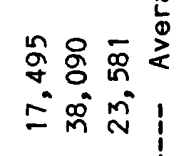 & 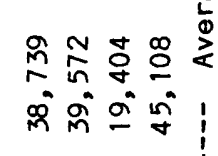 \\
\hline 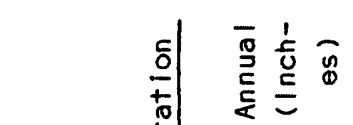 & 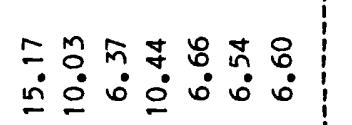 & 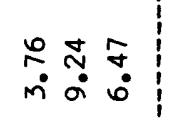 & 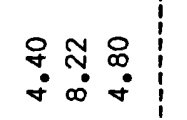 & 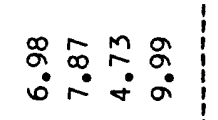 \\
\hline 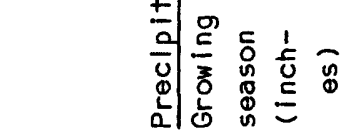 & 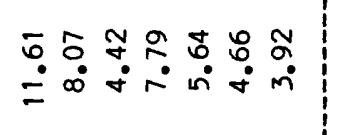 & 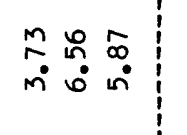 & 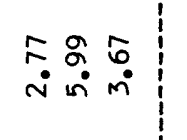 & 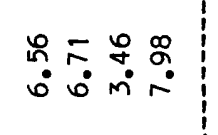 \\
\hline 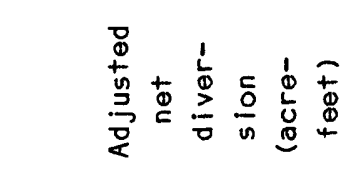 & 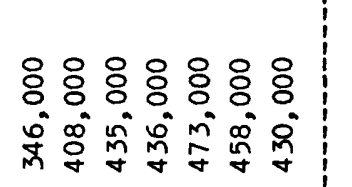 & 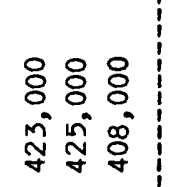 & 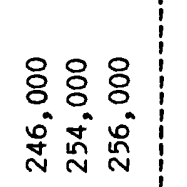 & 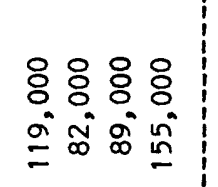 \\
\hline & 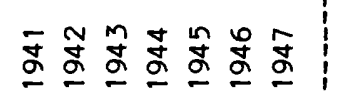 & 焉导虽 & 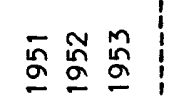 & 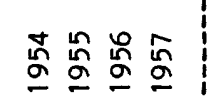 \\
\hline
\end{tabular}




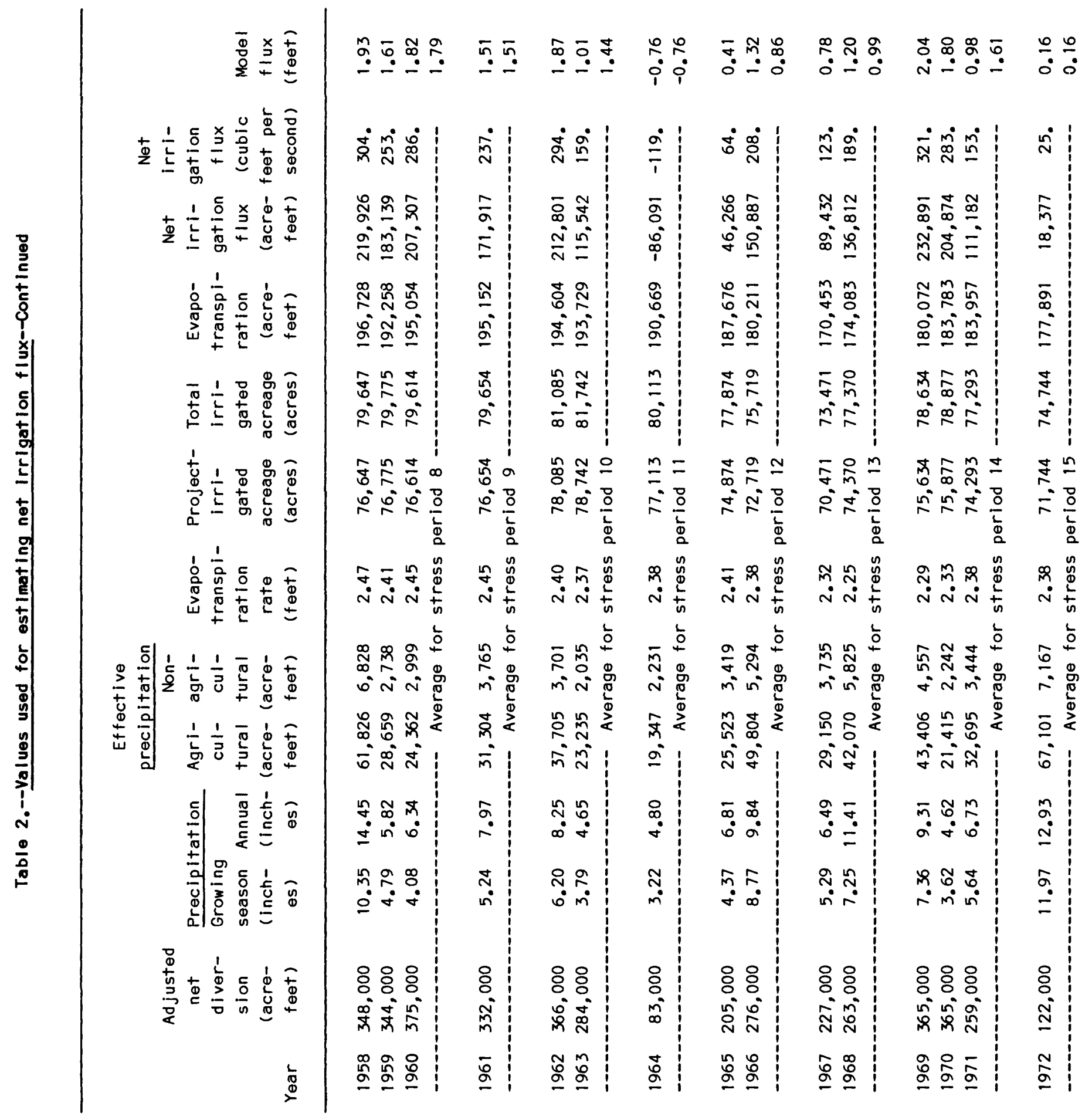




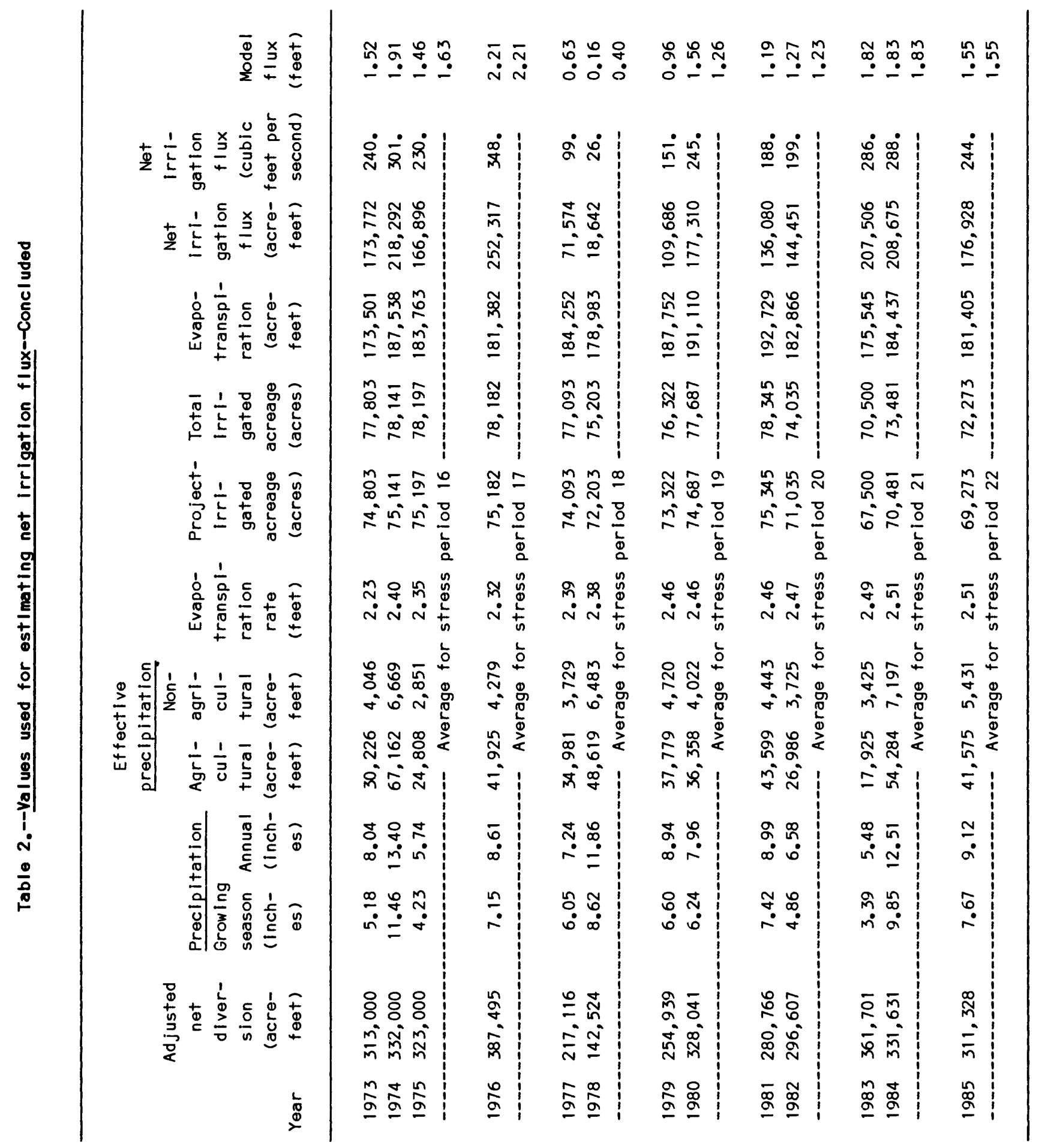




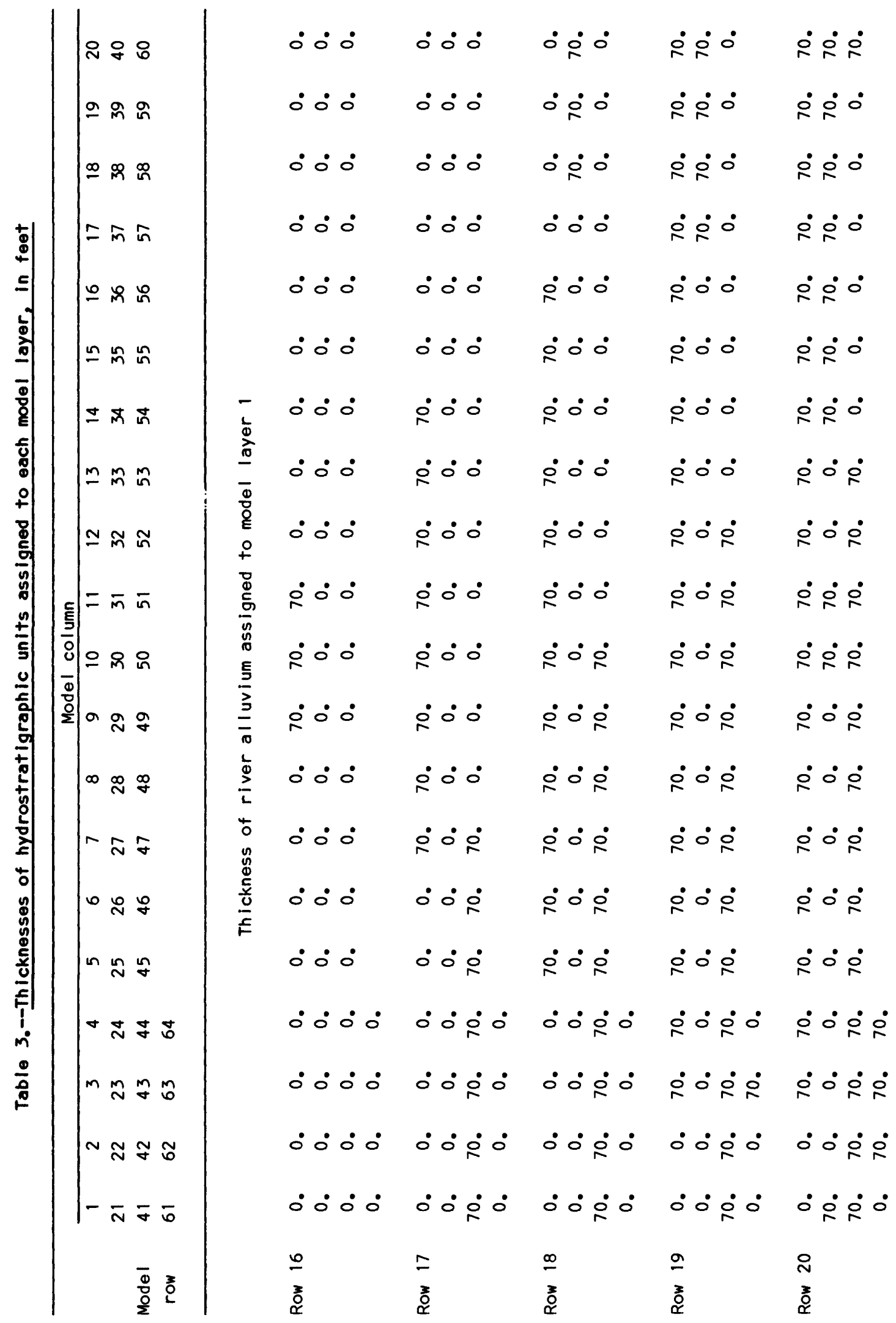




\begin{tabular}{|c|c|c|c|c|c|c|}
\hline 용 & $\dot{R} \dot{R}$ & $\dot{2} \dot{2}$ & $\dot{8} \dot{\circ}$ & $\dot{2} \dot{\circ}$ & $\dot{2} \dot{\circ}$ & $\dot{\therefore} \therefore$ \\
\hline 응 & $\dot{R} \dot{R}$ & $\dot{\therefore} \dot{8}$ & $\dot{\therefore} \dot{8}$ & $\dot{2} \dot{\circ}$ & $\dot{2} \dot{\circ}$ & $\dot{\therefore} \dot{\circ}$ \\
\hline$\stackrel{\infty}{\infty} \underset{n}{\infty} \stackrel{\infty}{n}$ & $\dot{R} \dot{\circ}$ & $\dot{i} \dot{i}$ & $\dot{2} \dot{i}$ & $\dot{i} \dot{8}$ & $\dot{\therefore} \dot{\circ}$ & $\dot{2} \dot{\circ}$ \\
\hline$=i n$ in & $\dot{\therefore} \dot{\circ}$ & $\dot{2} \dot{2}$ & $\dot{\therefore} \dot{8}$ & $\dot{\therefore} \dot{8}$ & $\dot{2} \dot{\circ}$ & $\dot{\therefore} \dot{\circ}$ \\
\hline 음ํ ํㅜㄴ & $\dot{\therefore} \dot{2}$ & $\dot{2} \dot{8}$ & $\dot{2} \dot{8}$ & $\dot{2} \dot{\circ}$ & $\dot{2} \dot{R}$ & $\therefore \dot{0}$ \\
\hline$\underline{n}$ 占 & $\dot{2} \dot{8}$ & $\dot{\therefore} \dot{2}$ & $\dot{\therefore} \dot{2}$ & $\dot{2} \dot{2}$ & $\dot{2} \dot{2}$ & $\dot{\circ} \dot{R}$ \\
\hline \pm 品 & $\dot{2} \dot{R}$ & $\dot{\therefore} \dot{\therefore}$ & $\dot{\therefore} \dot{\therefore}$ & $\dot{\therefore} \dot{\therefore}$ & $\dot{\circ} \dot{\therefore}$ & $\dot{\circ} \dot{2}$ \\
\hline$m m i n$ & $\dot{2} \dot{8}$ & $\dot{\therefore} \dot{8}$ & $\dot{2} \dot{\circ} \dot{2}$ & $\dot{2} \dot{i}$ & $\therefore \dot{\circ}$ & $\therefore \dot{0}$ \\
\hline$\simeq \approx N$ & $\dot{i} \dot{R}$ & $\dot{i} \dot{2}$ & $\dot{2} \dot{2} \dot{R}$ & $\dot{\circ} \dot{8}$ & $\therefore \dot{8}$ & $\therefore \dot{i}$ \\
\hline$\underline{\underline{E}}=\bar{m} \bar{n}$ & $\dot{\therefore} \dot{8}$ & $\dot{\therefore} \dot{8}$ & $\dot{\therefore} \dot{8}$ & $\dot{\circ} \dot{8}$ & $\dot{\circ} \dot{8}$ & $\therefore \dot{\circ}$ \\
\hline 웡응 용 & $\dot{2} \dot{R}$ & $\dot{2} \dot{8}$ & $\dot{\circ} \dot{i}$ & $\dot{\circ} \dot{R}$ & $\therefore \dot{R}$ & $\dot{\circ} \dot{0}$ \\
\hline ㅎํㄹ & $\dot{\therefore} \dot{\circ}$ & $\dot{\circ} \dot{8}$ & $\dot{\circ} \dot{R}$ & $\dot{\circ} \dot{R}$ & $\therefore \dot{\therefore}$ & $\therefore \dot{8}$ \\
\hline$\infty \stackrel{\infty}{\sim} \stackrel{\infty}{*}$ & $\dot{\therefore} \dot{8}$ & $\therefore \dot{\therefore}$ & $\therefore \dot{i}$ & $\dot{\circ} \dot{8}$ & $\therefore \dot{8}$ & $\therefore \dot{8}$ \\
\hline$-\hat{N}$ & $\dot{\therefore} \dot{R}$ & $\therefore \dot{\therefore}$ & $\therefore \dot{8}$ & $\dot{\circ} \dot{8}$ & $\therefore \dot{8}$ & $\therefore \dot{8}$ \\
\hline $02 \%$ & $\dot{R} \dot{R}$ & $\therefore \dot{\therefore}$ & $\dot{\circ} \dot{8}$ & $\therefore \dot{0}$ & $\therefore \dot{8}$ & $\therefore \dot{8}$ \\
\hline $\ln \stackrel{n}{\sim}$ & $\dot{\therefore} \dot{8}$ & $\therefore \dot{\therefore}$ & $\dot{\circ} \dot{R}$ & $\therefore \dot{\therefore}$ & $\therefore \dot{8}$ & $\therefore \dot{8}$ \\
\hline$A \stackrel{d}{A}$ & $\dot{\therefore} \dot{\circ} \dot{\circ}$ & $\dot{\circ} \dot{8} \dot{0}$ & $\therefore \dot{i} \dot{0}$ & $\therefore \dot{8}$ & $\therefore \dot{8}$ & $\therefore \dot{\therefore}$ \\
\hline$m \stackrel{\sim}{\sim} \underset{\sigma}{ } \tilde{b}$ & $\dot{\therefore} \dot{\therefore} \dot{\circ}$ & $\dot{\therefore} \dot{\therefore} \dot{\circ}$ & $\dot{\circ} \dot{\circ} \dot{\circ}$ & $\dot{\circ} \dot{\therefore} \dot{\circ}$ & $\dot{\circ} \dot{\therefore} \dot{\circ}$ & $\dot{\circ} \dot{R} \dot{\circ}$ \\
\hline$N \approx \mathcal{*}$ & $\dot{\circ} \dot{i} \dot{i}$ & $\dot{i} \dot{i} \dot{R}$ & $\dot{\therefore} \dot{\therefore} \dot{\circ}$ & $\dot{\circ} \dot{\circ}$ & $\dot{\circ} \dot{\circ}$ & $\dot{\circ} \dot{\circ}$ \\
\hline$-\bar{N} \bar{\sigma}$ & $\dot{\circ} \dot{i} \dot{R}$ & $\dot{\circ} \dot{i} \dot{R}$ & $\dot{\circ} \dot{\circ} \dot{\circ}$ & $\dot{\circ} \dot{\therefore} \dot{\circ}$ & $\therefore \dot{\therefore} \dot{\circ}$ & $\dot{\circ} \dot{\therefore} \dot{\circ}$ \\
\hline & $\bar{N}$ & N & $\stackrel{m}{N}$ & A & $\stackrel{n}{N}$ & $\stackrel{2}{N}$ \\
\hline$\frac{0}{2} \frac{1}{2}$ & $\stackrel{\bar{z}}{\alpha}$ & ב⿳亠口冋口𧘇 & ơ & $\underset{\alpha}{z}$ & בे & $\stackrel{z}{\alpha}$ \\
\hline
\end{tabular}




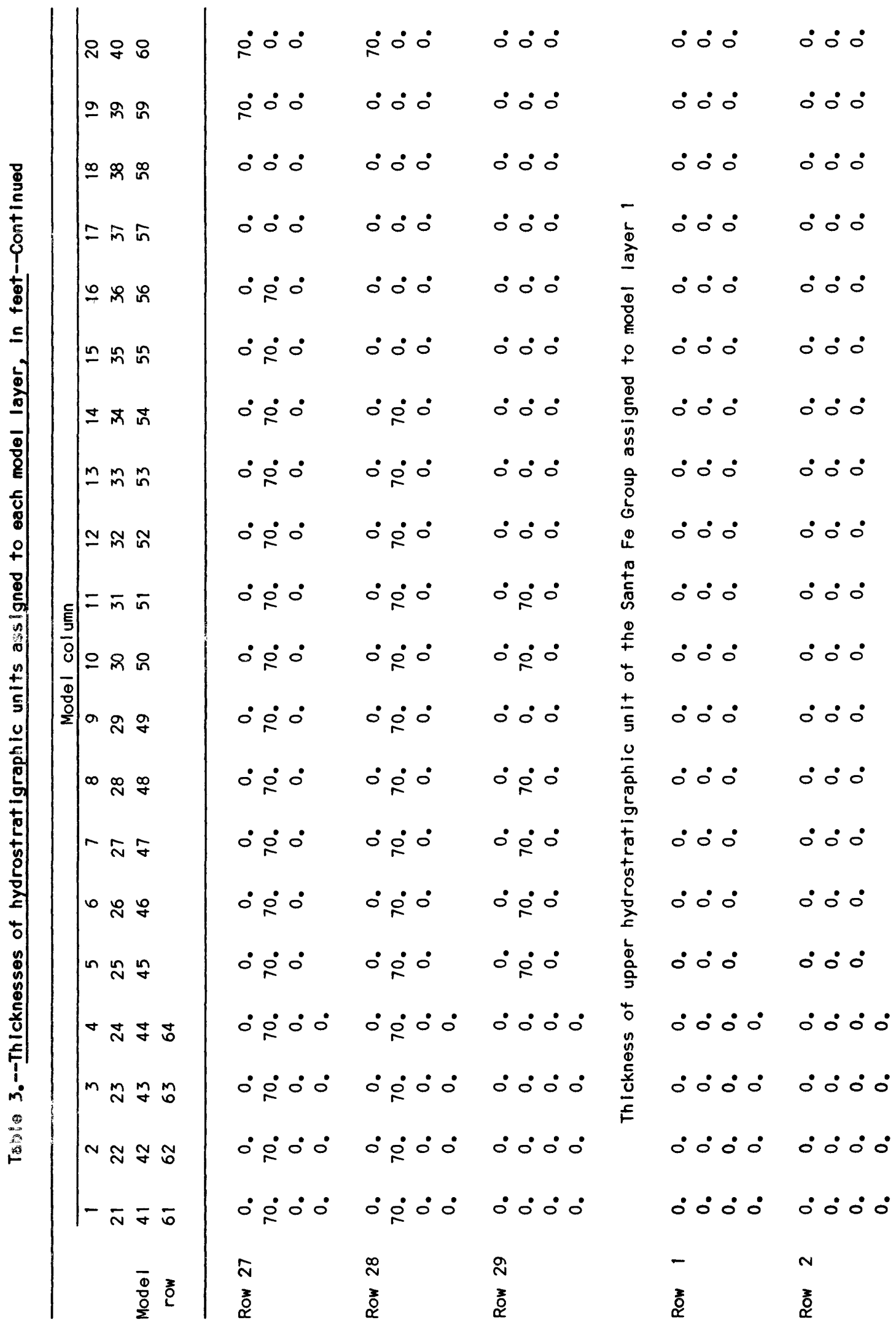




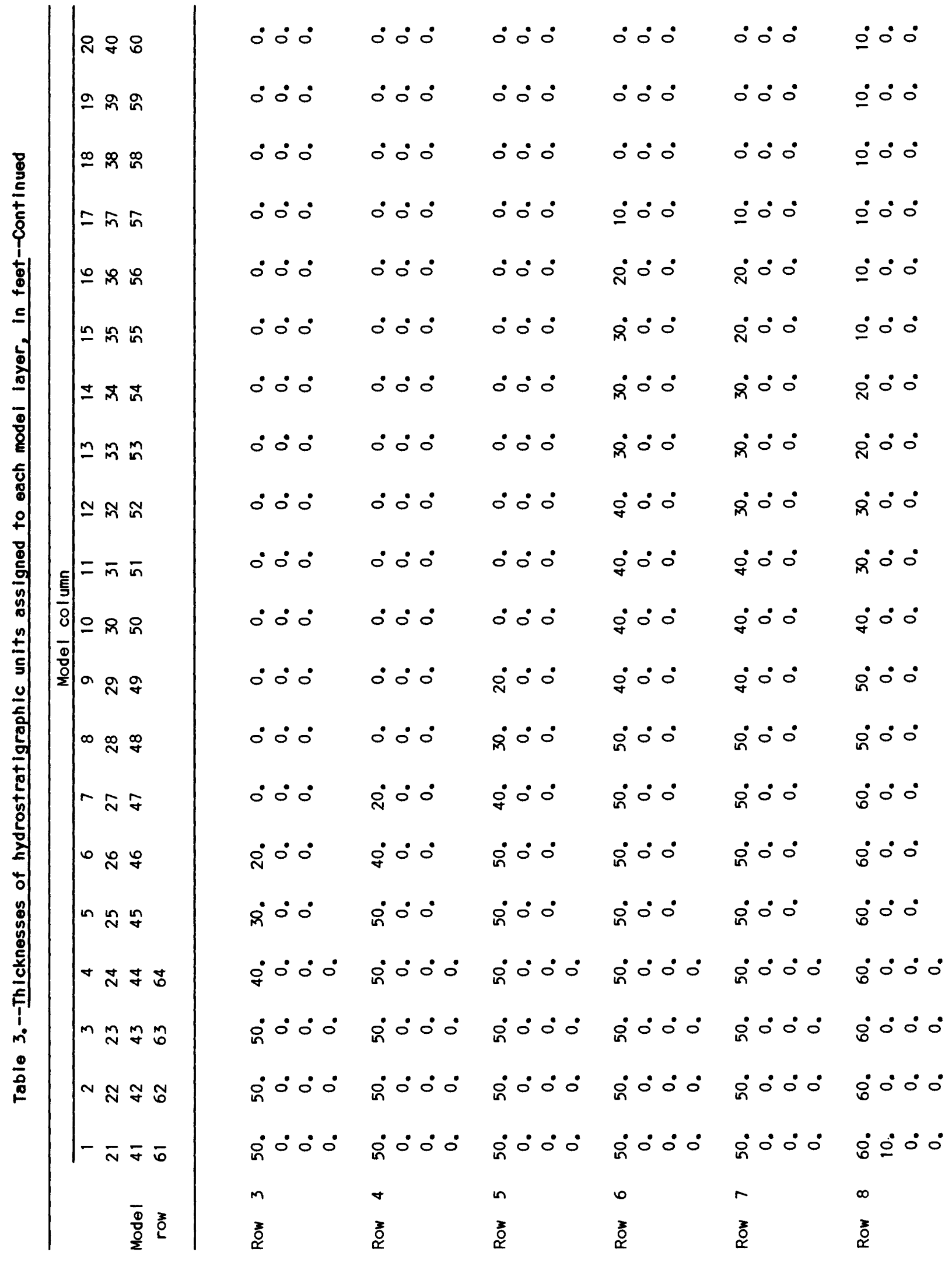




\begin{tabular}{|c|c|c|c|c|c|c|}
\hline 요 요 & $\therefore \dot{0}$ & $\therefore \stackrel{\circ}{\circ}$ & $\dot{\circ} \dot{\circ}$ & $\dot{\circ} \dot{\circ} \dot{0}$ & $\dot{\circ} \dot{\circ}$ & $\dot{\circ} \underset{i}{\circ}$ \\
\hline 요 & $\therefore \dot{0}$ & $\dot{\circ} \dot{\circ} \dot{0}$ & $\dot{\circ} \dot{\circ} \dot{\circ}$ & $\dot{\circ} \dot{\circ} \circ$ & $\dot{\circ} \dot{\circ}$ & $\dot{\circ} \dot{\circ} \dot{0}$ \\
\hline 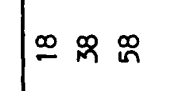 & $\dot{\circ} \dot{\circ} \dot{\circ}$ & $\therefore \dot{\varnothing}$ & $\dot{\circ} \check{\circ} \dot{\circ}$ & $\dot{\circ} \dot{\circ}$ & $\dot{\circ} \underset{\infty}{\dot{0}} \dot{0}$ & $\dot{\circ} \dot{8}$ \\
\hline$\pm \hat{n} \hat{n}$ & $\dot{\circ} \dot{i}$ & $\dot{\circ} \dot{\circ}$ & $\therefore \dot{\circ} \circ$ & $\dot{\circ} \dot{0}$ & $\therefore \dot{\circ}$ & $\dot{0} \dot{\infty}$ \\
\hline$\cong \Re$ ํำ & $\therefore \circ \dot{\circ}$ & $\dot{\circ} \dot{\sim} \dot{\circ}$ & $\dot{\circ} \dot{\circ} \dot{\circ}$ & $\dot{0} \dot{8}$ & $\dot{\circ} \dot{\sim}$ & $\dot{\circ} \dot{\sim}$ \\
\hline$\cong n$ & $\dot{0} \dot{0} \dot{0}$ & $\dot{\circ} \dot{0}$ & $\dot{\circ} \dot{0} 0$ & $\therefore \dot{0}$ & $\circ 0^{\circ} 0^{\circ}$ & 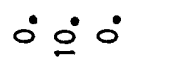 \\
\hline 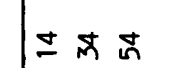 & $\dot{\circ} \dot{\circ} \dot{0}$ & $\therefore \dot{0} \dot{0}$ & $\dot{0} \dot{0} \dot{0}$ & $\dot{0} \dot{0} \dot{0}$ & $\dot{0} \dot{\circ} \dot{0}$ & $\dot{\circ} \dot{\circ}$ \\
\hline$m \tilde{m} \tilde{n}$ & $\dot{0} \dot{0} \dot{0}$ & $\dot{0} \dot{0}$ & $\dot{\circ} \dot{0} \dot{0}$ & $\dot{0} \dot{0}$ & $\dot{0} \dot{\circ} 0$ & $\therefore \dot{0} \dot{0}$ \\
\hline$\cong \widetilde{N}$ & $\dot{n} \dot{\circ} \dot{\circ}$ & $\therefore \dot{\circ}$ & $\therefore 0^{\circ}$ & $\therefore \dot{0}$ & $\dot{\circ} \dot{\circ}$ & $\therefore 0^{\circ}$ \\
\hline$\underline{E}=\bar{m} \bar{n}$ & $\dot{q} \dot{\circ} \dot{\circ}$ & $\dot{\circ} \dot{\circ} \dot{\circ}$ & $\therefore \dot{0}$ & $\therefore \dot{0}$ & $\dot{\circ} \dot{\circ} \dot{0}$ & $\dot{\circ} \dot{\circ}$ \\
\hline 이응 욤 & $\dot{0} \circ 0^{\circ}$ & $\therefore \dot{0}$ & $\therefore \dot{0}$ & $\dot{0} \dot{0}$ & $\dot{0} 0^{\circ}$ & $\dot{\circ}$ \\
\hline 일 & $\dot{0} \dot{\circ} \dot{0}$ & $\dot{0} \dot{0}$ & $\dot{0} \dot{\circ}$ & $\dot{0} \dot{0} \dot{0}$ & $\dot{0} \dot{0} \dot{0}$ & $\dot{\circ} \check{\circ} \dot{\circ}$ \\
\hline$\infty \stackrel{\infty}{\infty} \stackrel{\infty}{+}$ & $\dot{8} \dot{0} \dot{\circ}$ & $\dot{0} \dot{\circ}$ & $\therefore \dot{0}$ & $\dot{0} \circ 0^{\circ}$ & ○ & ¿ \\
\hline$\sim \approx F$ & $\dot{0} \dot{\circ}$ & $\therefore 0^{\circ} \circ$ & $\dot{\circ} \dot{0}$ & $\dot{0} \dot{0}$ & ல் & வ் \\
\hline 0 న & 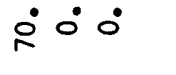 & $\dot{\circ} \dot{\circ}$ & $\circ 0^{\circ} \circ$ & வ $\dot{q} \dot{\circ}$ & $\dot{\circ} \dot{\circ}$ & $\dot{\square} \dot{i} \dot{0}$ \\
\hline $\ln \cong$ & $\dot{\circ} \dot{\circ} \dot{\circ}$ & $\dot{\infty} \dot{\circ} \dot{\circ}$ & ㅇㅇㅇ & $\dot{0} \dot{8} \dot{\circ}$ & ச் & ட் \\
\hline 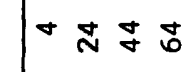 & $\therefore \circ 0^{\circ}$ & $\dot{\infty} \circ \dot{\circ}$ & $\dot{\infty} \dot{\circ} \dot{\circ}$ & $\dot{0} \dot{0} \dot{\circ}$ & $\dot{\circ} \doteq \dot{\circ} 0^{\circ}$ & $\dot{\square} \dot{\circ} \dot{\circ} \circ$ \\
\hline$m \underset{\sim}{m} \underset{\sigma}{\sigma}$ & $\dot{0} \dot{\circ} 0 \dot{0}$ & $\dot{\infty} \dot{\circ} \dot{0}$ & $\dot{\infty} \dot{0} \dot{0} \dot{0}$ & $\dot{0} \dot{0} \dot{0}$ & $\dot{+} \dot{\circ} \dot{\circ}$ & $\stackrel{i}{\circ} \dot{\circ} \dot{\circ}$ \\
\hline$\sim \mathcal{N} \mathscr{์}$ & $\dot{\circ} \dot{\circ} \dot{\circ}$ & $\dot{\infty} \dot{\circ} \dot{\circ} \dot{0}^{\circ}$ & $\dot{\infty} \dot{\circ} \dot{\circ}$ & $\therefore \dot{\circ} \dot{\circ}$ & $\dot{\circ} \dot{\circ} \dot{\circ} \dot{\circ}$ & ஜ் $\dot{\circ} \dot{\circ}$ \\
\hline$-\bar{N} \bar{\sigma} \bar{\sigma}$ & $\dot{\circ} \dot{\circ} \dot{\circ}$ & $\dot{\infty} \dot{\circ} \dot{\circ}$ & $\dot{\infty} \dot{\infty} \dot{\circ}$ & $\dot{\infty} \dot{\circ} \dot{8}$ & $\dot{\circ} \dot{\circ} \dot{\circ} 0^{\circ}$ & $\ddot{i} \circ \dot{\circ} \dot{\circ}$ \\
\hline & $a$ & 으 & $=$ & $\cong$ & $\underline{m}$ & \pm \\
\hline$\frac{8}{2}$ & $\underset{\propto}{\tilde{z}}$ & है & בे & בे & ֻे & בे \\
\hline
\end{tabular}




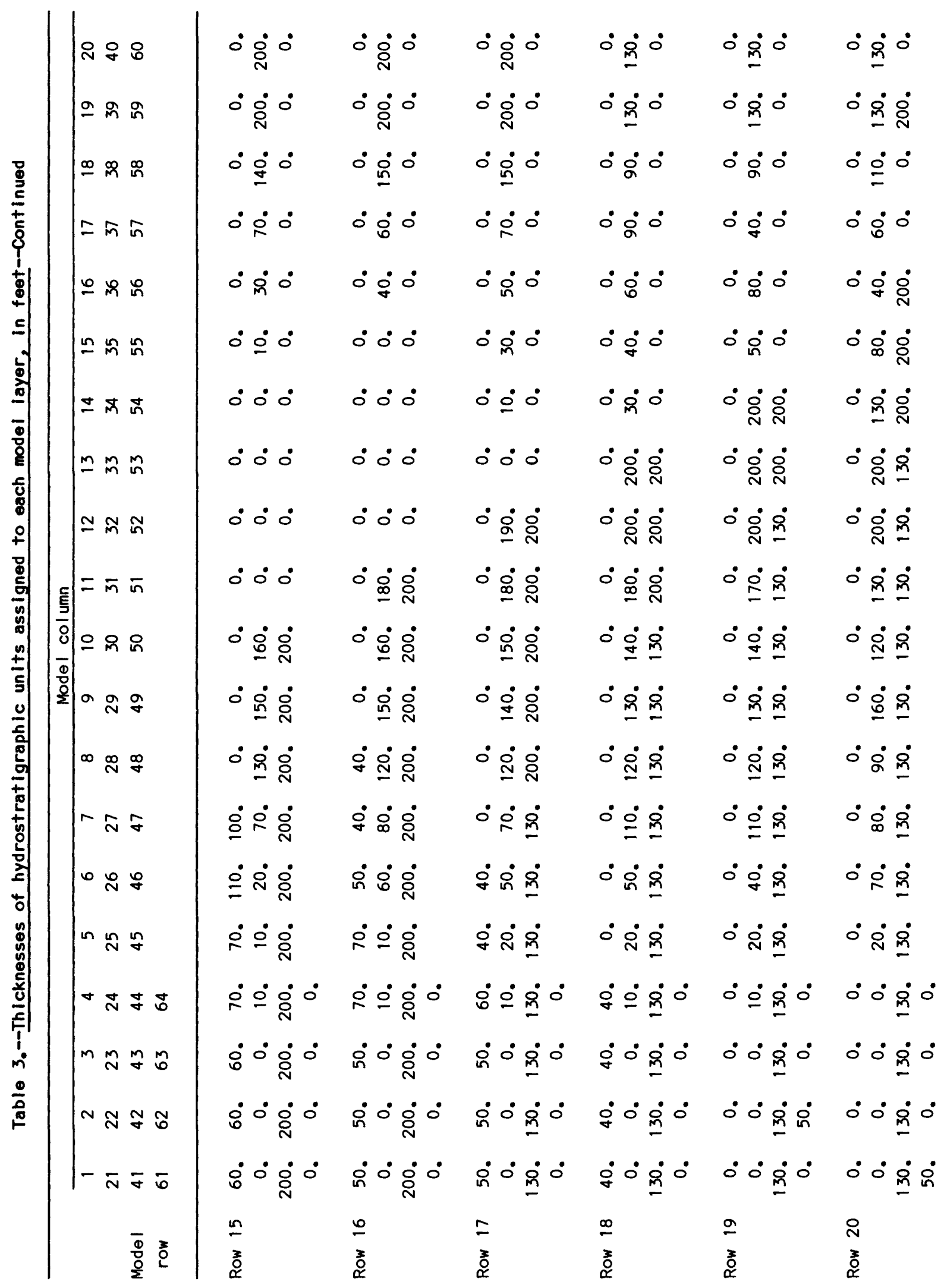




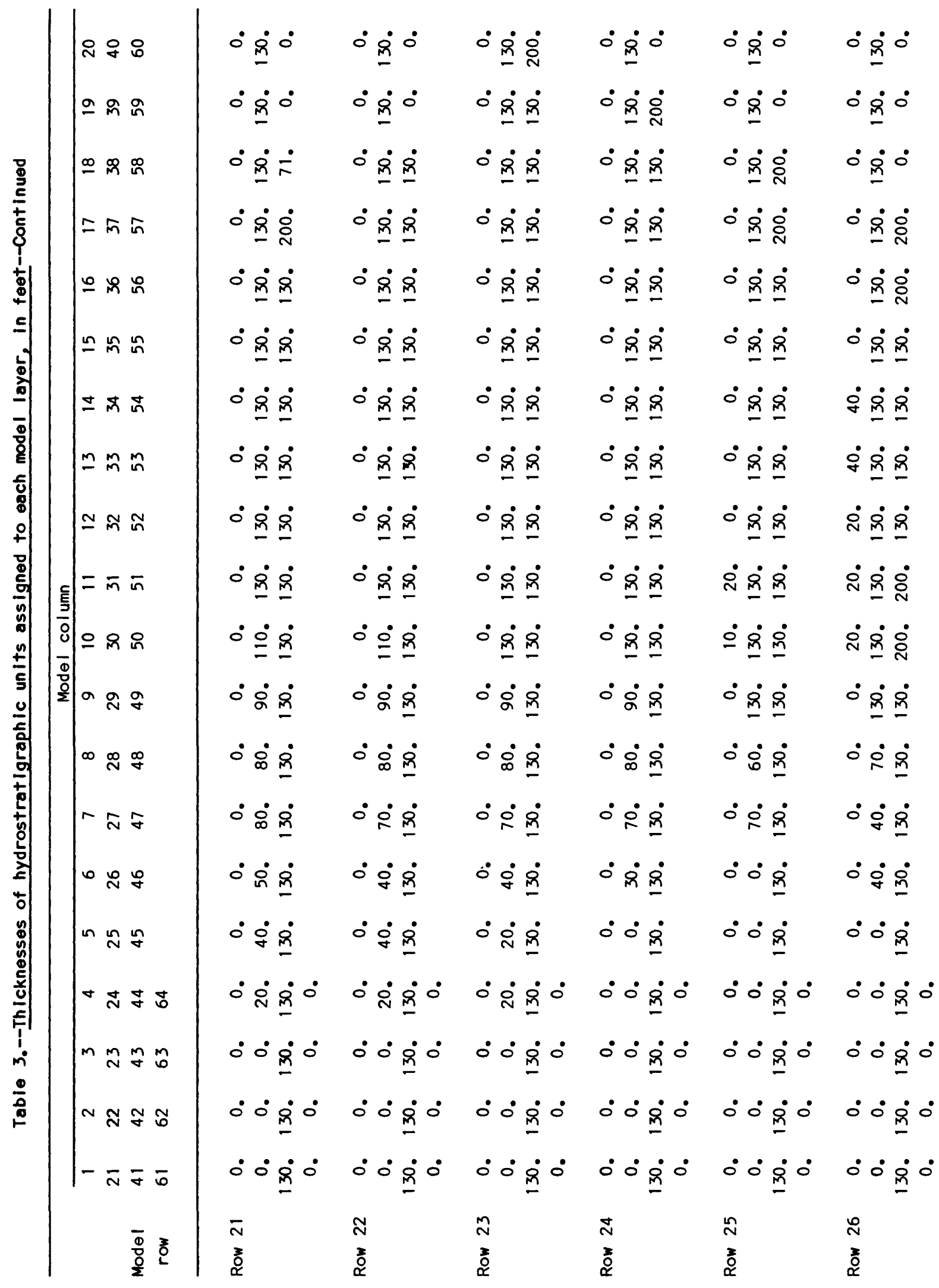




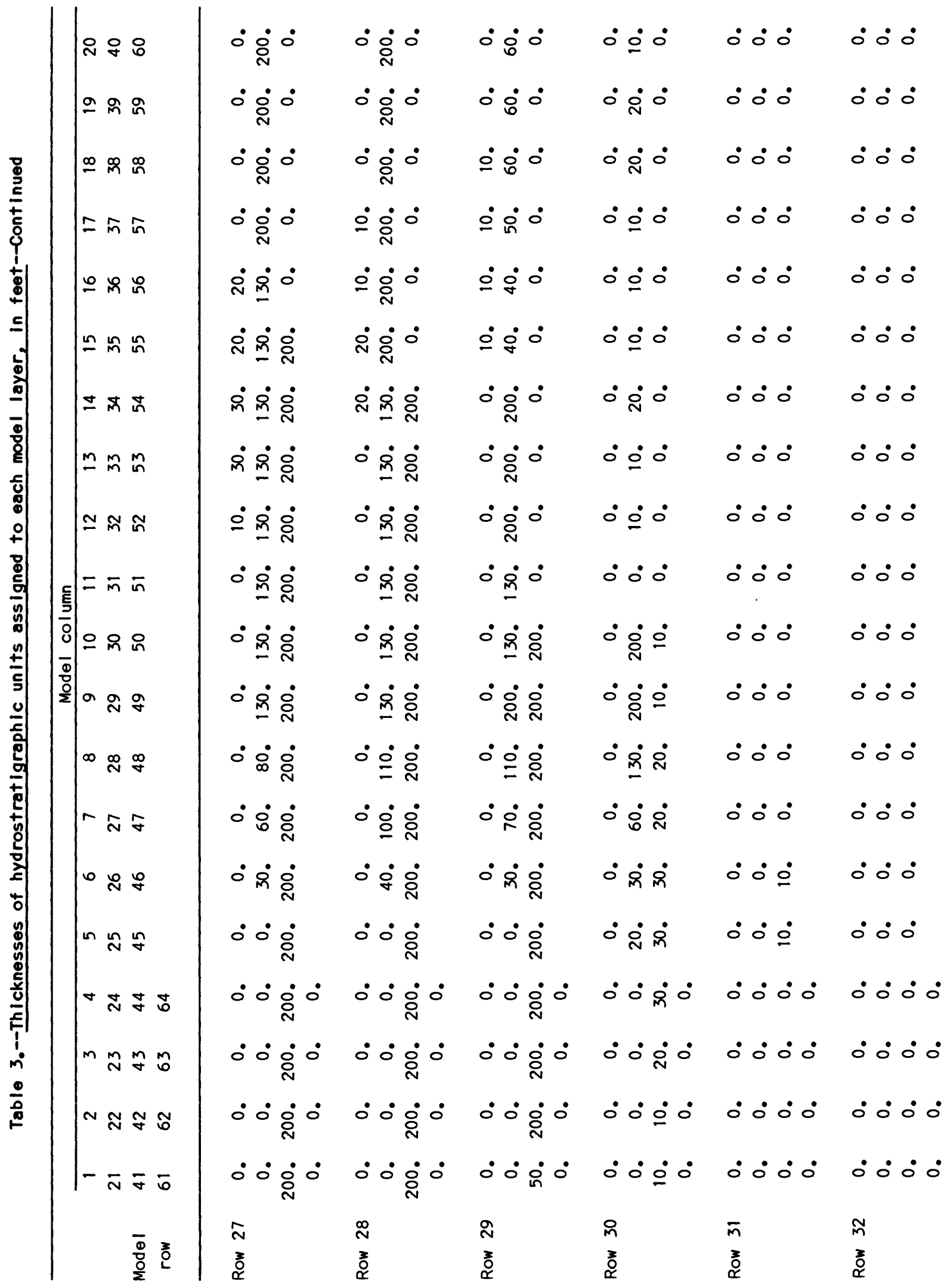




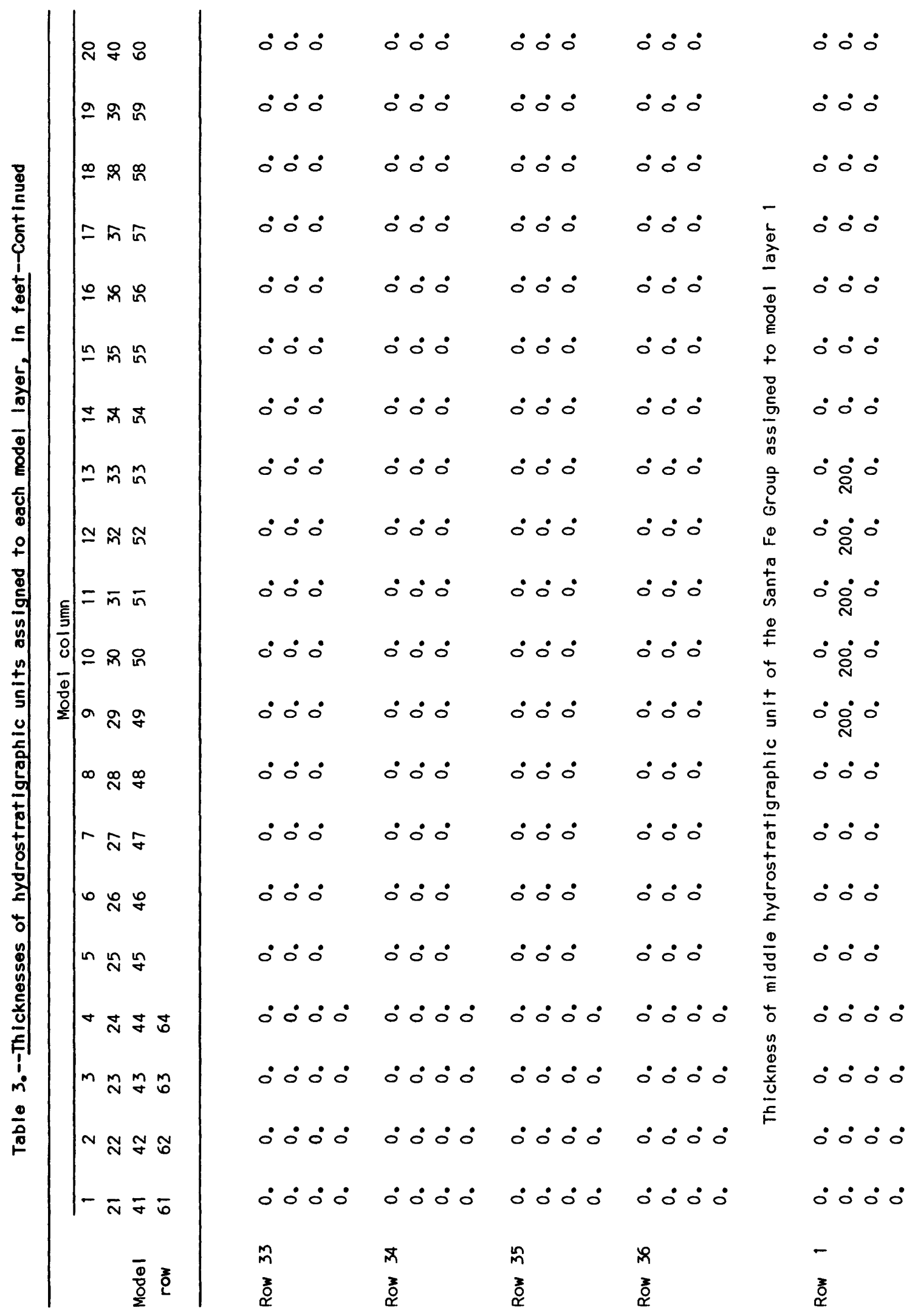




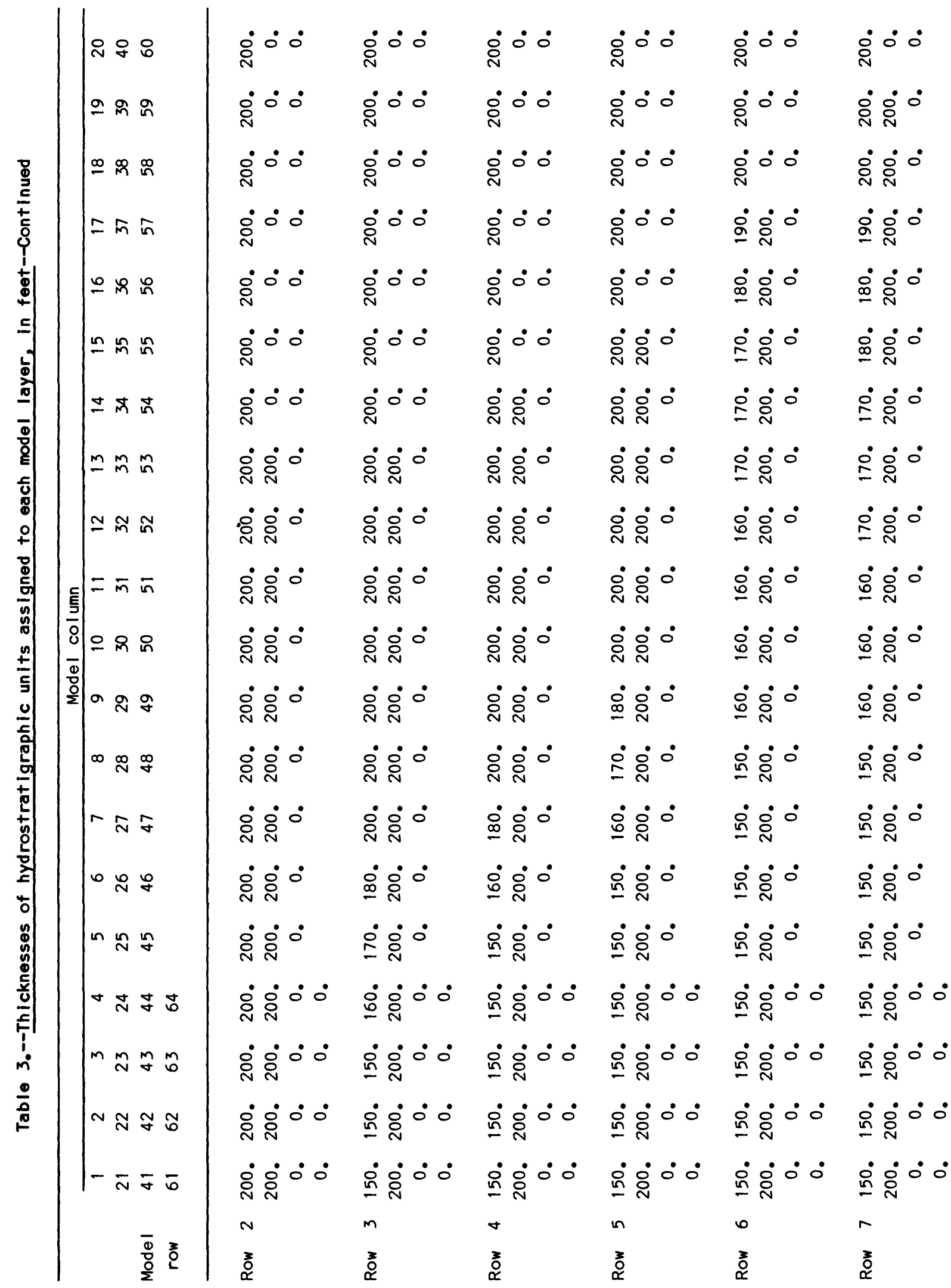




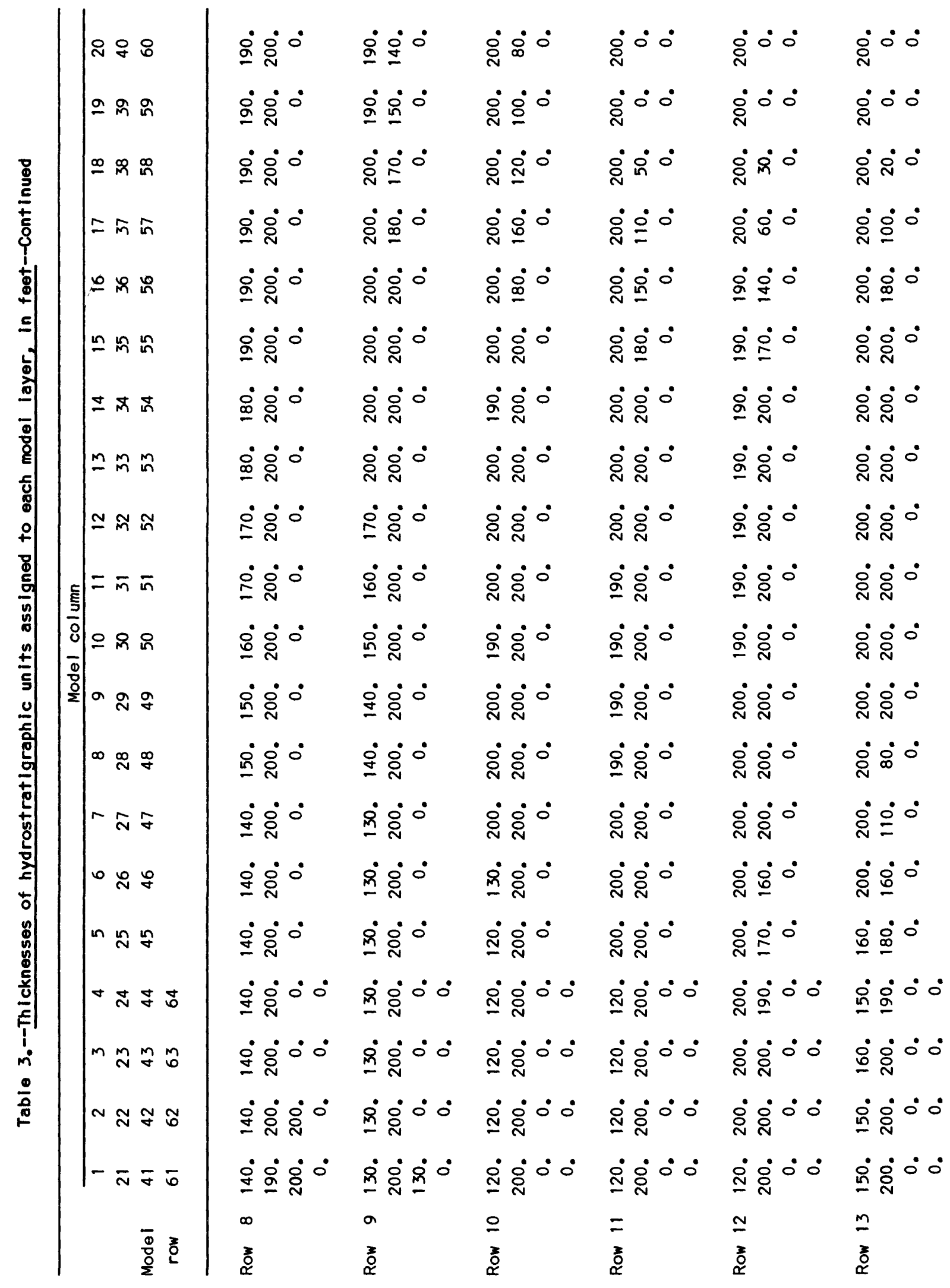




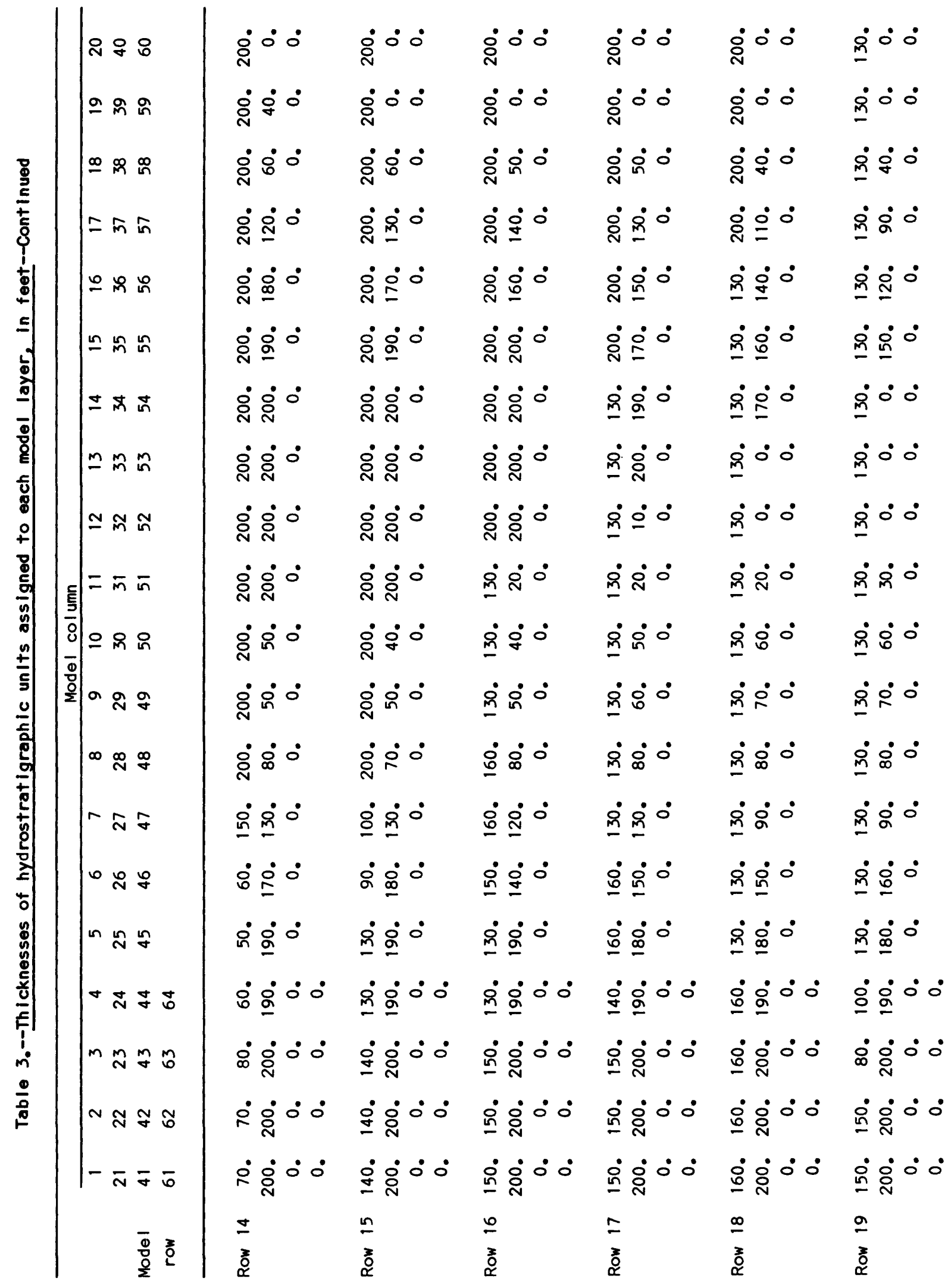




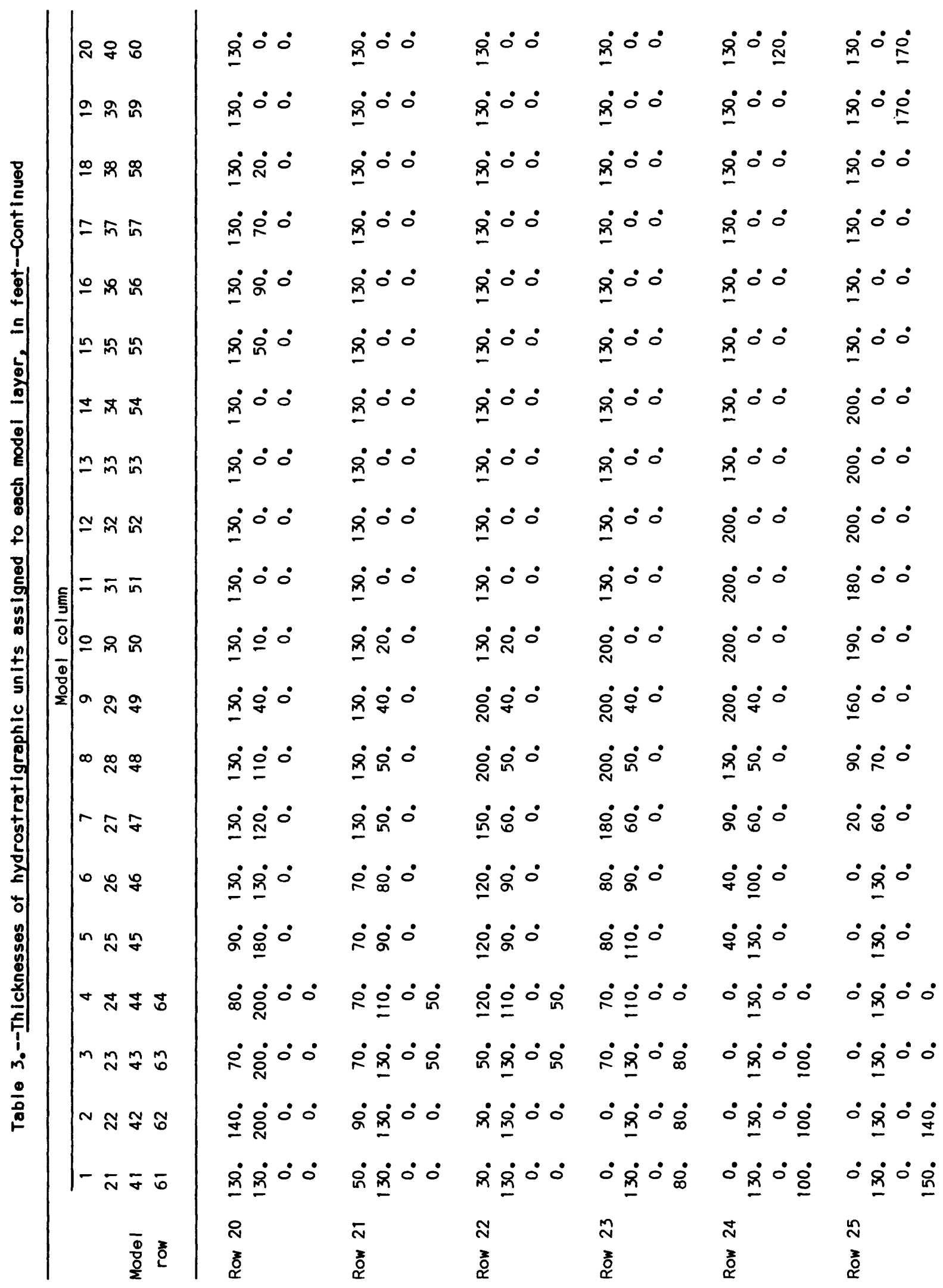




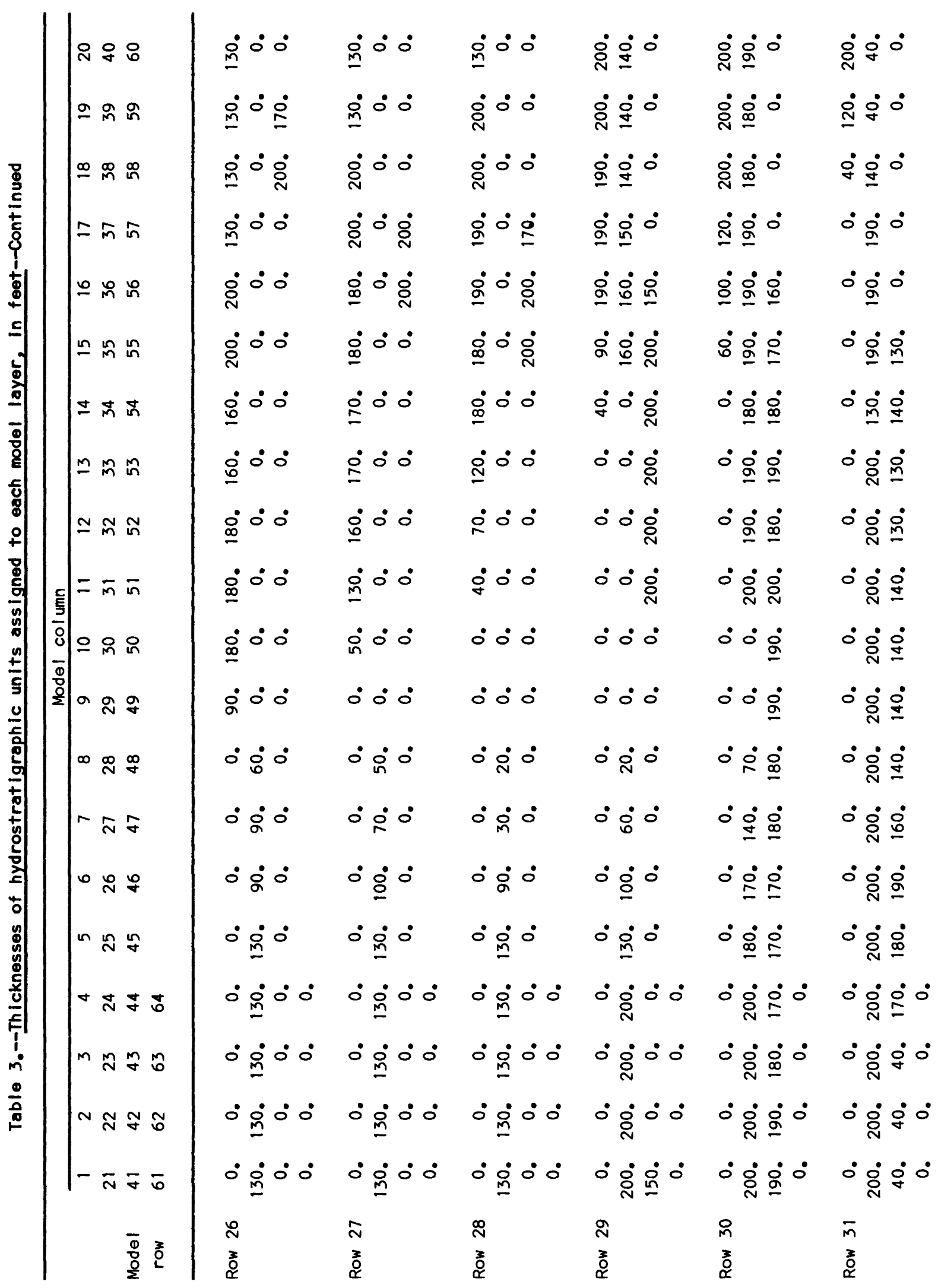




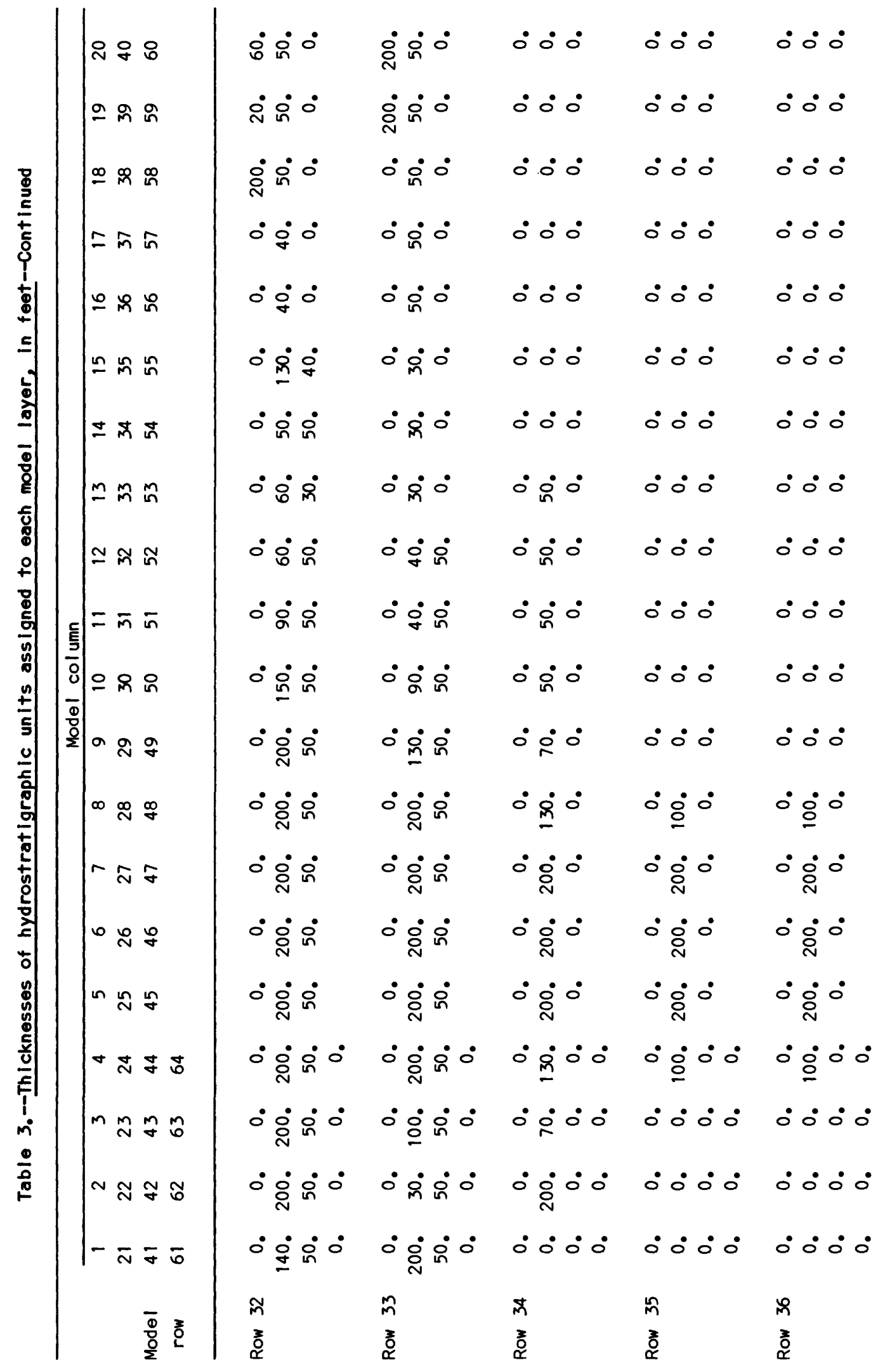




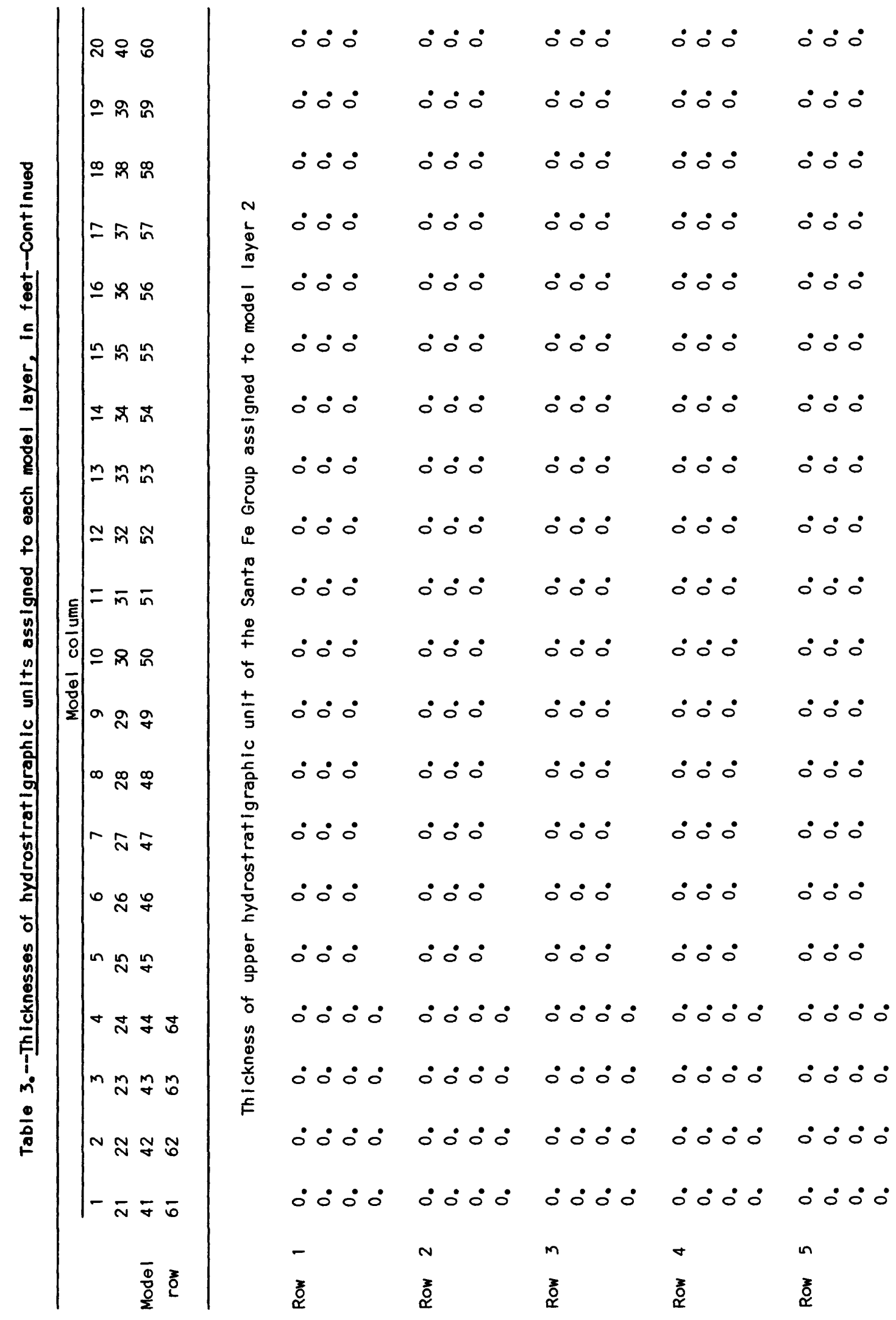




\begin{tabular}{|c|c|c|c|c|c|c|}
\hline 용 & $\therefore \therefore$ & $\therefore \circ$ & $\therefore \therefore \circ$ & $\therefore \therefore 0$ & $\therefore 0^{\circ}$ & $\therefore 0^{\circ}$ \\
\hline 요 î ô & $\therefore \therefore \circ$ & $\therefore \circ 0$ & $\therefore 0^{\circ}$ & $\therefore \circ 0$ & $\therefore 0^{\circ}$ & $\circ 0^{\circ}$ \\
\hline$\stackrel{\infty}{\infty} \underset{n}{\infty}$ & $\therefore \circ:$ & $\therefore \circ \dot{0}$ & $\therefore \circ \dot{0}$ & $\therefore \circ \dot{0}$ & $\therefore \therefore \circ$ & $\therefore \circ \circ$ \\
\hline$=\bar{m} n$ & $\therefore \therefore \therefore$ & $\therefore \therefore \circ$ & $\therefore \circ \dot{0}$ & $\therefore \therefore \circ$ & $\therefore \therefore \circ$ & $\therefore \therefore$ \\
\hline$\because \Re$ ํํำ & $\therefore \therefore \circ$ & $\therefore \circ \dot{0}$ & $\therefore \therefore \circ$ & $\therefore \therefore \circ$ & $\therefore \circ 0$ & $\therefore \circ 0$ \\
\hline nn m $n$ & $\therefore \therefore \circ$ & $\therefore \therefore \dot{0}$ & $\therefore \therefore \circ$ & $\therefore \therefore \circ$ & $\therefore \therefore \dot{0}$ & $\therefore \therefore$ \\
\hline \pm ম & $\therefore \circ 0$ & $\therefore \circ 0$ & $\therefore \circ \dot{0}$ & $\therefore \circ \dot{0}$ & $\therefore \circ \dot{0}$ & $\therefore \therefore \circ$ \\
\hline$m m n$ & $\therefore \circ 0$ & $\therefore \circ 0$ & $\therefore \circ 0$ & $\therefore \therefore \circ$ & $\therefore \circ \dot{0}$ & $\therefore \circ \dot{0}$ \\
\hline$\simeq \approx \approx$ & $\therefore \therefore \circ$ & $\therefore \circ 0$ & $\therefore \circ \dot{0}$ & $\therefore \therefore \circ$ & $\therefore \circ$ & $\therefore \therefore$ \\
\hline$\underline{f}=\bar{m} \bar{n}$ & $\therefore \therefore \circ$ & $\therefore \dot{0}$ & $\therefore \therefore$ & $\therefore \therefore \dot{0}$ & $\therefore \therefore \dot{0}$ & $\therefore \therefore$ \\
\hline 웡응 용 & $\therefore \therefore \circ$ & $\therefore \circ 0^{\circ}$ & $\therefore \dot{0}$ & $\therefore \therefore \circ$ & $\therefore \therefore \circ$ & $\therefore \therefore$ \\
\hline ㅇํㄹ & $\therefore \therefore \circ$ & $\therefore \therefore$ & $\therefore \circ \circ$ & $\therefore \circ \dot{0}$ & $\therefore \circ \therefore$ & $\therefore \circ \circ$ \\
\hline$\infty \stackrel{\infty}{\sim} \stackrel{\infty}{+}$ & $\therefore \therefore \circ$ & $\therefore \circ 0$ & $\therefore \circ 0^{\circ}$ & $\therefore \therefore \circ$ & $\therefore \therefore \circ$ & $\therefore \dot{0}$ \\
\hline$n \hat{N}$ & $\therefore \therefore$ & $\therefore \dot{0}$ & $\therefore \therefore$ & $\therefore \therefore \circ$ & $\therefore \therefore \dot{0}$ & $\therefore \therefore$ \\
\hline $0 \stackrel{2}{\circ}$ & $\therefore \therefore \therefore$ & $\therefore \therefore \circ$ & $\therefore \therefore \dot{0}$ & $\therefore \therefore \circ$ & $\therefore \therefore \circ$ & $\therefore \dot{0}$ \\
\hline 吃 ๓ & $\therefore \therefore \circ$ & $\therefore \therefore$ & $\therefore \therefore$ & $\therefore \circ \dot{0}$ & $\therefore \circ \dot{0}$ & $\therefore \therefore$ \\
\hline 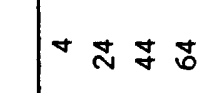 & $\therefore \therefore \therefore$ & $\therefore \therefore \dot{0}$ & $\therefore \dot{\circ} \dot{\circ}$ & $\therefore \circ \therefore$ & $\therefore \therefore \circ$ & $\therefore \circ \dot{\circ}$ \\
\hline$m \underset{\sim}{\sim} \underset{\sim}{m}$ & $\therefore \circ \dot{\circ}$ & $\therefore \circ \circ 0^{\circ}$ & $\therefore \circ \dot{\circ}$ & $\therefore \therefore \circ \dot{0}$ & $\therefore \circ \dot{\circ}$ & $\therefore \dot{\circ} \dot{\circ}$ \\
\hline$\sim \approx \mathcal{*}$ & $\therefore \circ \therefore$ & $\therefore \therefore \circ$ & $\therefore \therefore \therefore$ & $\therefore \dot{\circ} \dot{\circ} \dot{0}$ & $\therefore \therefore \circ$ & $\therefore \circ \dot{\circ} \dot{0}$ \\
\hline$-\bar{N} \bar{\sigma}$ & $\therefore \circ \therefore$ & $\dot{0} \dot{0} \dot{\circ}$ & $\dot{0} \dot{0} \dot{\circ}$ & $\dot{0} \dot{\circ} \dot{\circ}$ & $\therefore \therefore \therefore$ & $\therefore \circ \dot{\circ} \dot{\circ}$ \\
\hline & 0 & r & $\infty$ & $a$ & 음 & $=$ \\
\hline$\frac{0}{2} \frac{0}{2}$ & $\stackrel{7}{o}$ & 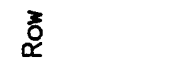 & 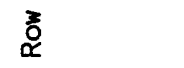 & ֻे & 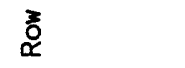 & 产 \\
\hline
\end{tabular}




\begin{tabular}{|c|c|c|c|c|c|c|}
\hline is \& & $\dot{0} \dot{\infty} \dot{0}$ & $\therefore \dot{\circ}$ & $\therefore \dot{0}$ & $\therefore \therefore$ & $\therefore \therefore \dot{0}$ & $\therefore \therefore$ \\
\hline 응 용 & $\therefore \dot{\circ}$ & $\therefore \therefore$ & $\therefore \therefore$ & $\therefore \therefore$ & $\therefore \therefore$ & $\therefore \dot{0}$ \\
\hline$\infty \mathscr{m} \stackrel{\infty}{n}$ & $\therefore \therefore$ & $\therefore \dot{p} \dot{0}$ & $\therefore \therefore$ & $\therefore \therefore$ & $\therefore \circ$ & $\therefore \therefore$ \\
\hline$=n$ in & $\therefore \therefore$ & $\therefore \therefore$ & $\therefore \therefore \dot{0}$ & $\therefore \therefore \dot{0}$ & $\therefore \circ \dot{0}$ & $\therefore \circ$ \\
\hline$\simeq \stackrel{\circ}{10}$ & $\therefore \therefore \dot{0}$ & $\therefore \therefore$ & $\therefore \dot{0}$ & $\therefore \therefore$ & $\therefore \therefore \therefore$ & $\therefore \circ \circ$ \\
\hline nn m & $\therefore \therefore$ & $\therefore \therefore \circ$ & $\therefore \therefore$ & $\therefore \therefore \dot{0}$ & $\therefore \therefore \circ$ & $\therefore \circ \circ$ \\
\hline \pm 可苏 & $\therefore \therefore$ & $\therefore \therefore \therefore$ & $\therefore \therefore$ & $\therefore \therefore$ & $\therefore \therefore \circ$ & $\therefore \therefore \circ$ \\
\hline$m m i n$ & $\therefore \therefore$ & $\therefore \therefore$ & $\therefore \therefore$ & $\therefore \therefore$ & $\therefore \therefore$ & $\therefore \therefore$ \\
\hline$\simeq \approx \pi$ & $\therefore \circ \therefore$ & $\therefore \therefore \therefore$ & $\therefore \therefore$ & $\therefore \therefore$ & $\therefore \therefore \circ$ & $\dot{\circ} \dot{m} \cong$ \\
\hline$\underline{\underline{E}}=\bar{m} \bar{n}$ & $\therefore \dot{0}$ & $\therefore \therefore \dot{0}$ & $\therefore \dot{0}$ & $\therefore \therefore$ & $\therefore \therefore$ & $\therefore \dot{0}$ \\
\hline ㅎํ응 & $\therefore \therefore \therefore$ & $\therefore \therefore$ & $\therefore \therefore$ & $\therefore \dot{0}$ & $\therefore \therefore \dot{9}$ & $\therefore \dot{0}$ \\
\hline 인 & $\therefore \therefore$ & $\therefore \therefore$ & $\therefore \dot{0}$ & $\therefore \therefore \dot{m}$ & $\therefore \circ \stackrel{\grave{D}}{ }$ & $\therefore \dot{0}$ \\
\hline$\infty \stackrel{\infty}{\sim} \stackrel{\infty}{q}$ & $\therefore \therefore$ & $\therefore \circ$ & $\therefore \dot{0}$ & $\therefore \therefore \stackrel{ }{0}$ & $\therefore \therefore \dot{0}$ & $\therefore \dot{0}$ \\
\hline I & $\therefore \therefore$ & $\therefore \therefore \dot{p}$ & $\therefore \therefore \dot{0}$ & $\therefore \dot{0}$ & $\therefore \therefore \dot{0}$ & $\therefore \therefore \dot{8}$ \\
\hline $02 \%$ & $\therefore \dot{0}$ & $\therefore \therefore \dot{m}$ & $\therefore \dot{g}$ & $\therefore \therefore \stackrel{ }{0}$ & $\therefore \therefore \stackrel{9}{\dddot{0}}$ & $\therefore \therefore \stackrel{ }{0}$ \\
\hline $\ln \mathfrak{n}$ & $\therefore \dot{0}$ & $\therefore \dot{0}$ & $\therefore \dot{g}$ & $\therefore \therefore \stackrel{\dot{0}}{ }$ & $\therefore \therefore \stackrel{9}{\dddot{8}}$ & $\therefore \dot{0}$ \\
\hline$\Rightarrow d z A$ & $\therefore \therefore \stackrel{0}{0} \dot{0}$ & $\therefore \therefore \dot{0}$ & $\therefore \dot{\circ}$ & $\therefore \therefore \dot{0}$ & $\therefore \dot{0} \cong$ & $\therefore \dot{0} \dot{0}$ \\
\hline$m m m$ & $\therefore \dot{0} \stackrel{0}{0}$ & $\therefore \dot{0} \dot{0}$ & $\therefore \therefore \doteq$ & $\therefore \therefore \stackrel{0}{0}$ & $\therefore \dot{0} \cong$ & $\therefore \dot{0} \dot{0}$ \\
\hline$N \mathcal{N} \mathcal{N}$ & $\therefore \dot{\circ} \dot{0}$ & $\therefore \dot{0} \stackrel{0}{0}$ & $\therefore \therefore \dot{0}$ & $\therefore \dot{0} \dot{0}$ & $\therefore \therefore \therefore$ & $\therefore$ \\
\hline $\mid-\bar{\alpha} \bar{\sigma}$ & $\therefore \dot{\circ} \dot{0}$ & $\therefore \dot{\circ} \dot{0}$ & $\therefore \dot{0} \dot{0}$ & $\therefore \therefore \dot{0}$ & $\therefore \therefore \therefore$ & $\therefore$ \\
\hline & $\simeq$ & $\underline{m}$ & \pm & $\underline{n}$ & $\underline{-}$ & $=$ \\
\hline$\frac{0}{2} \frac{0}{2}$ & $\underset{\substack{z \\
\alpha}}{z}$ & $\underset{\alpha}{z}$ & $\underset{\alpha}{z}$ & $\stackrel{3}{\alpha}_{\alpha}^{z}$ & $\underset{0}{z}$ & 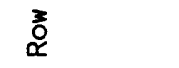 \\
\hline
\end{tabular}




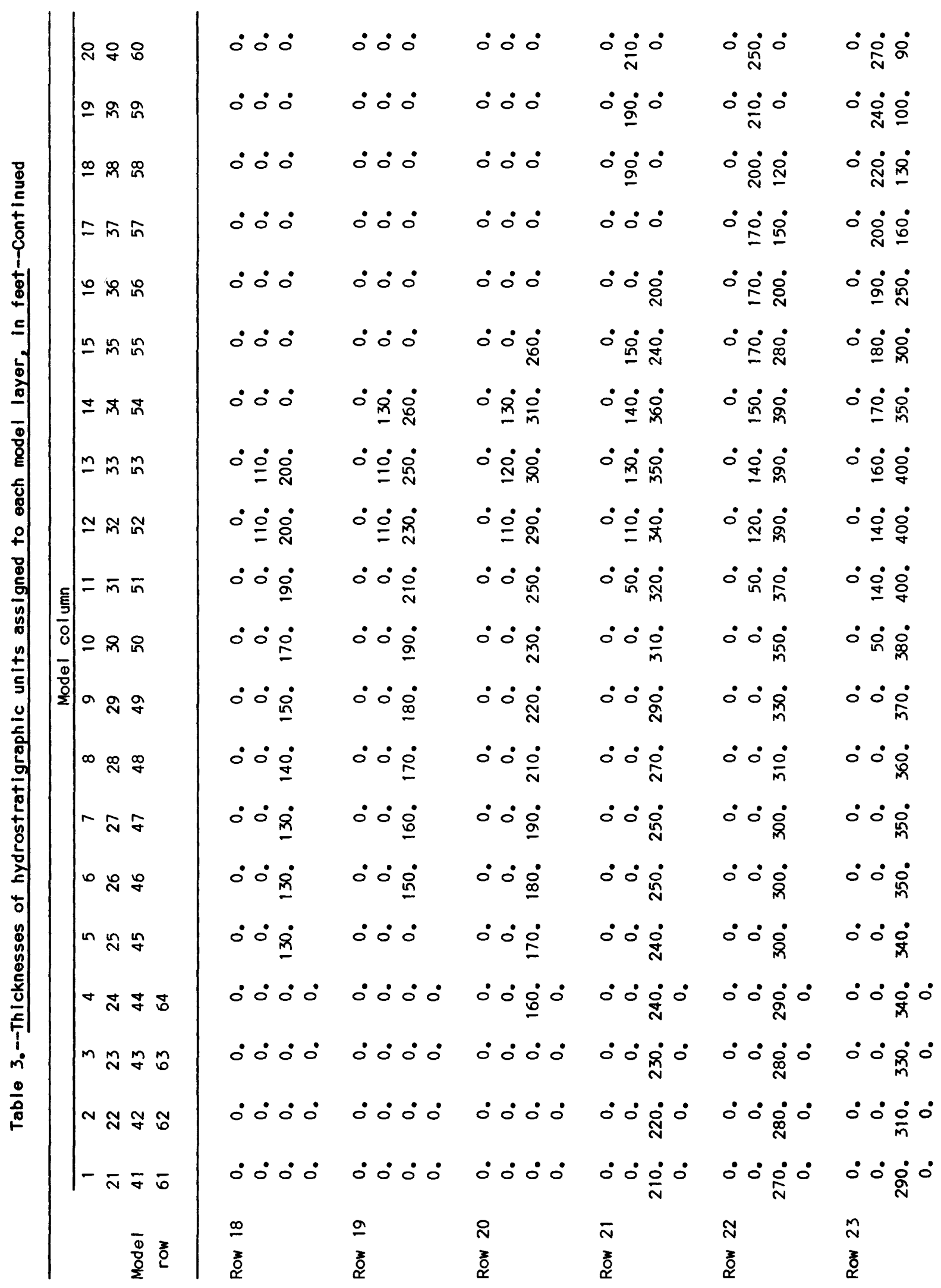




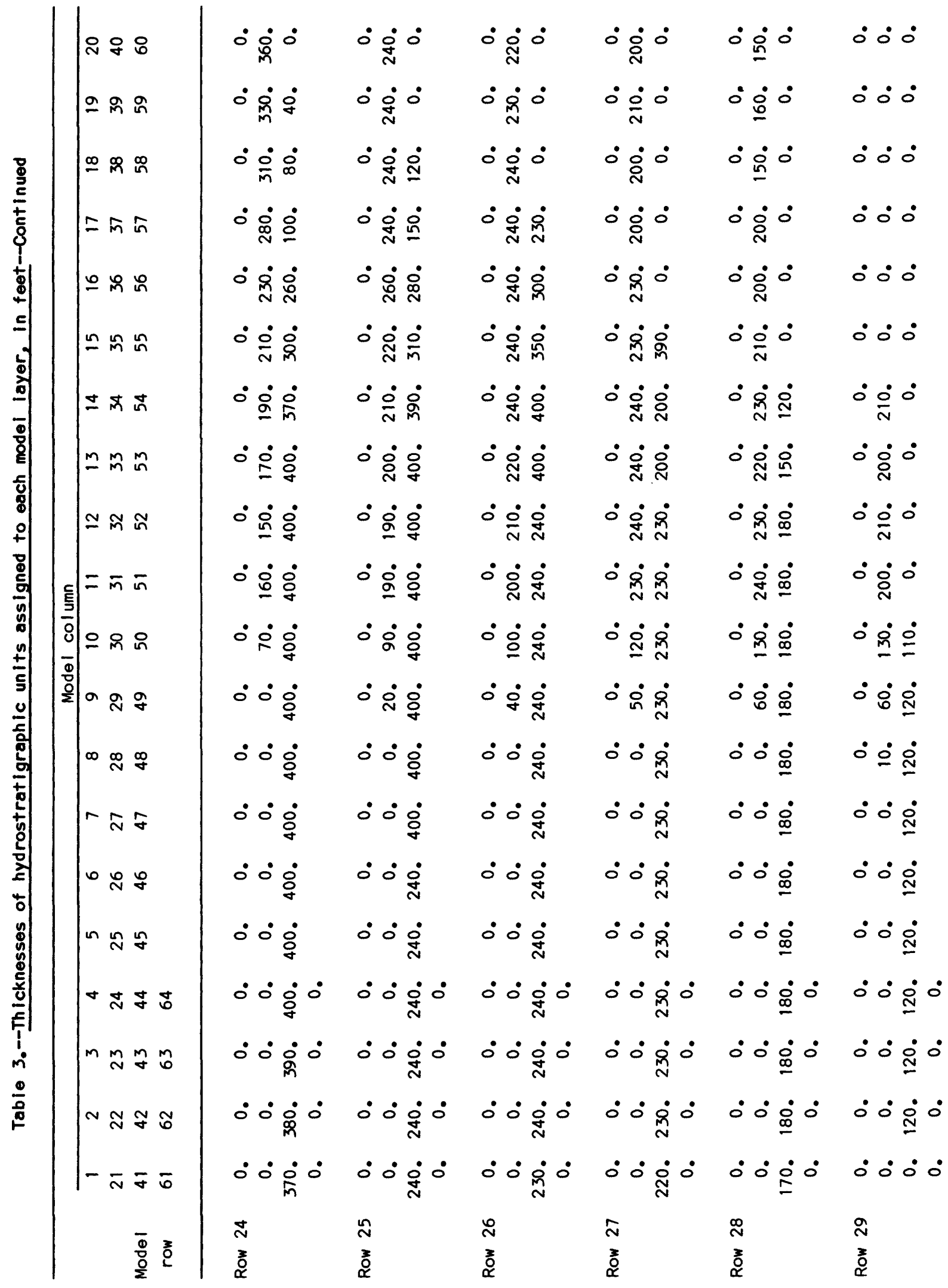




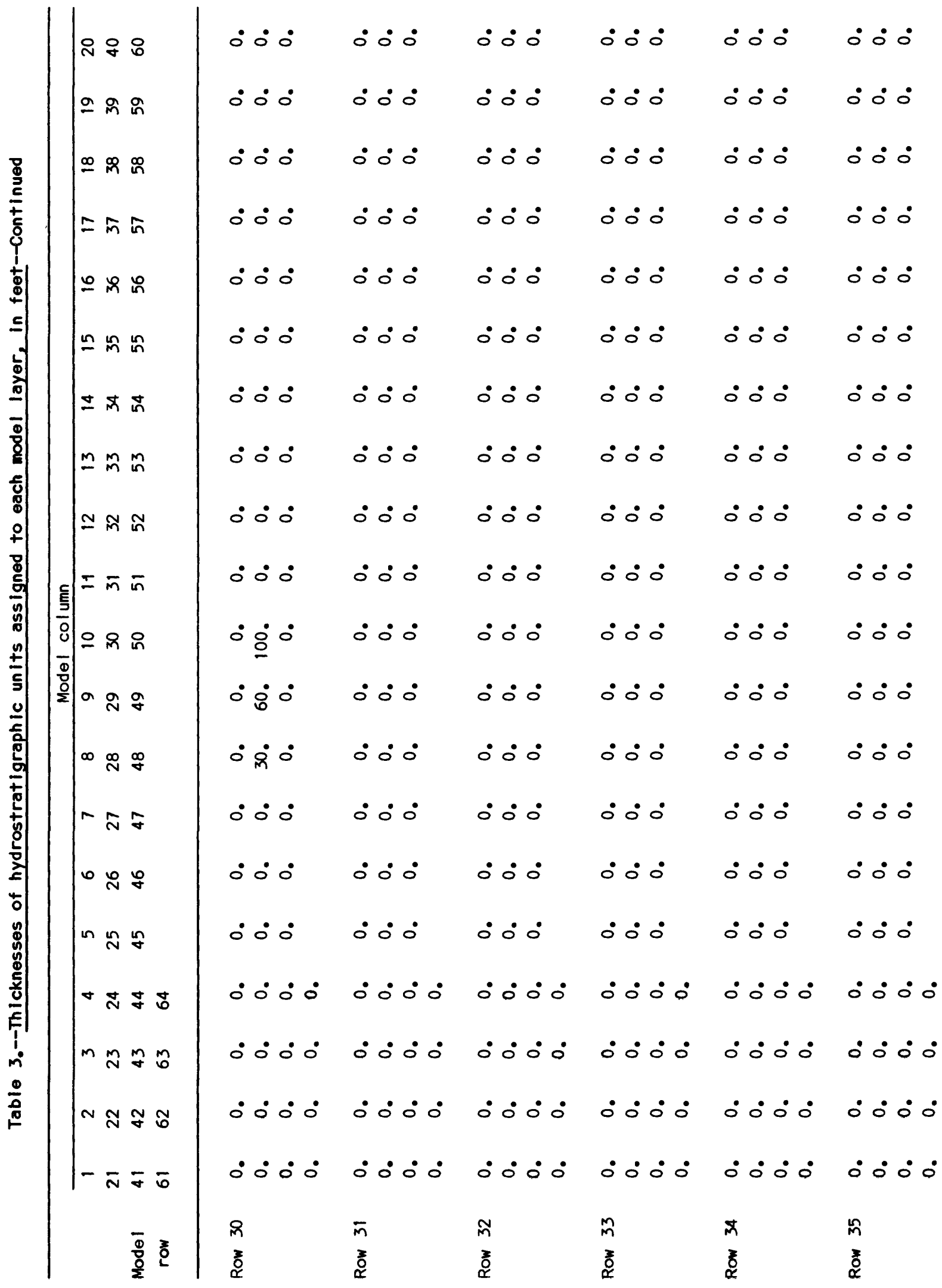




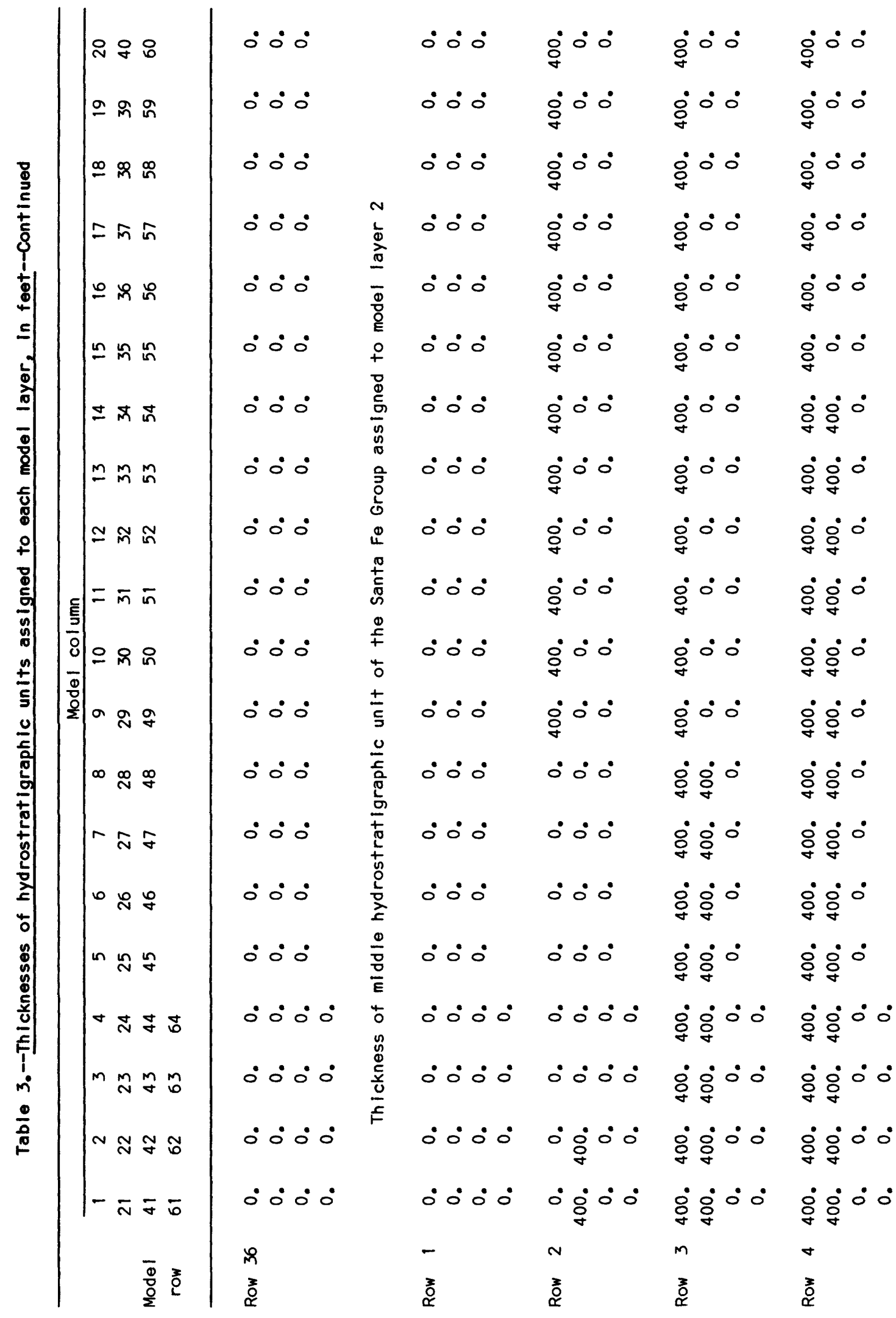




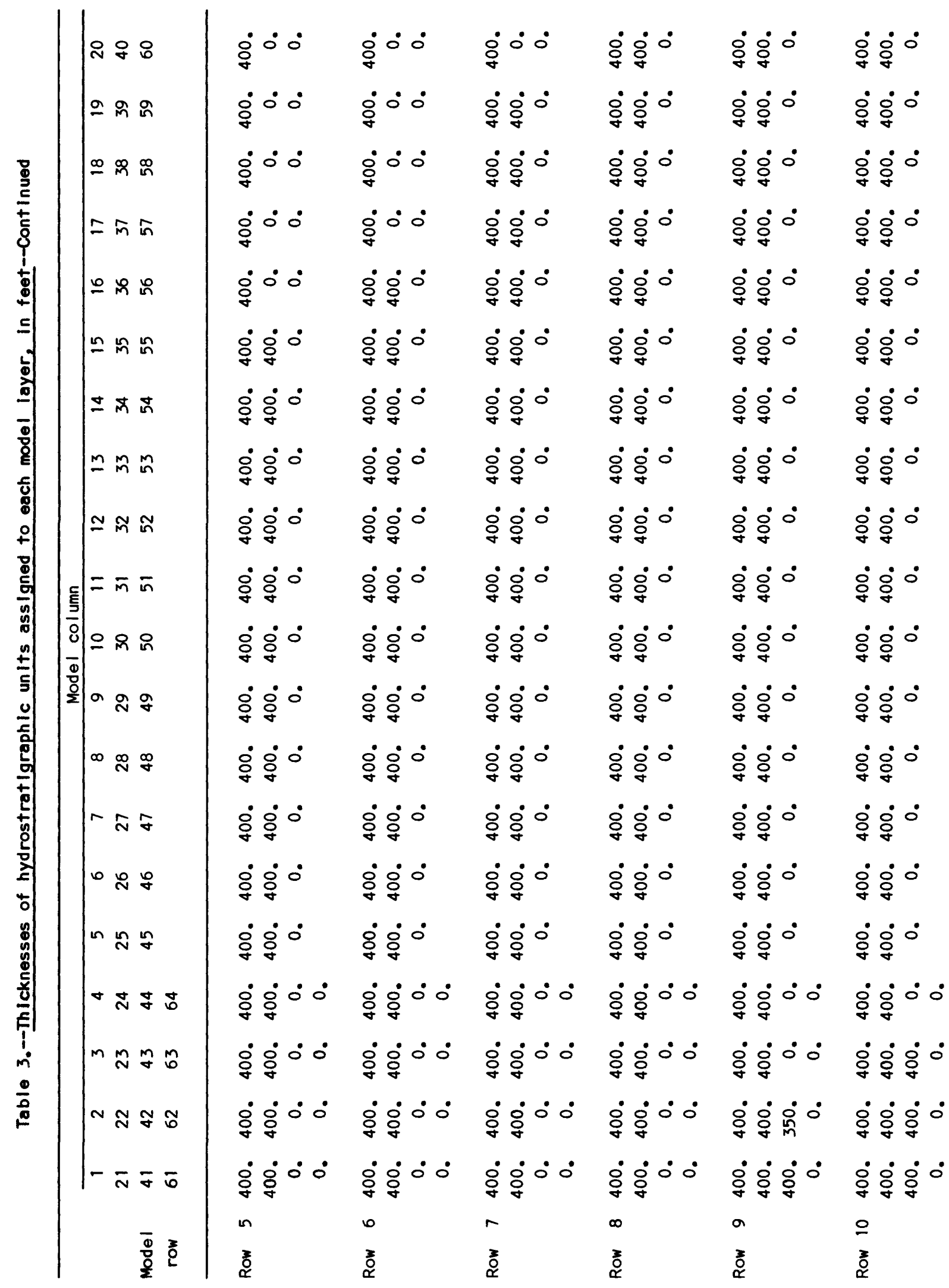




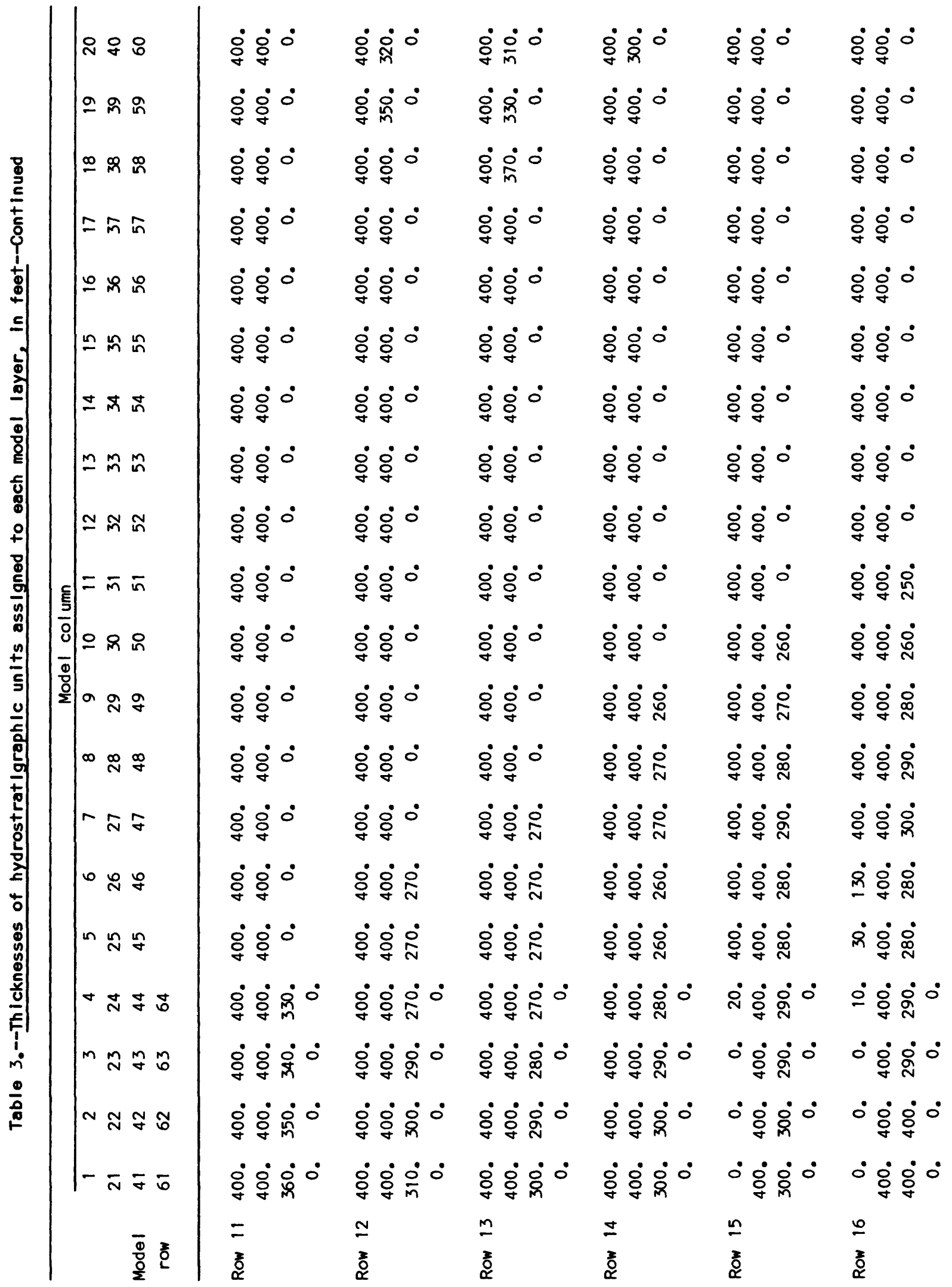




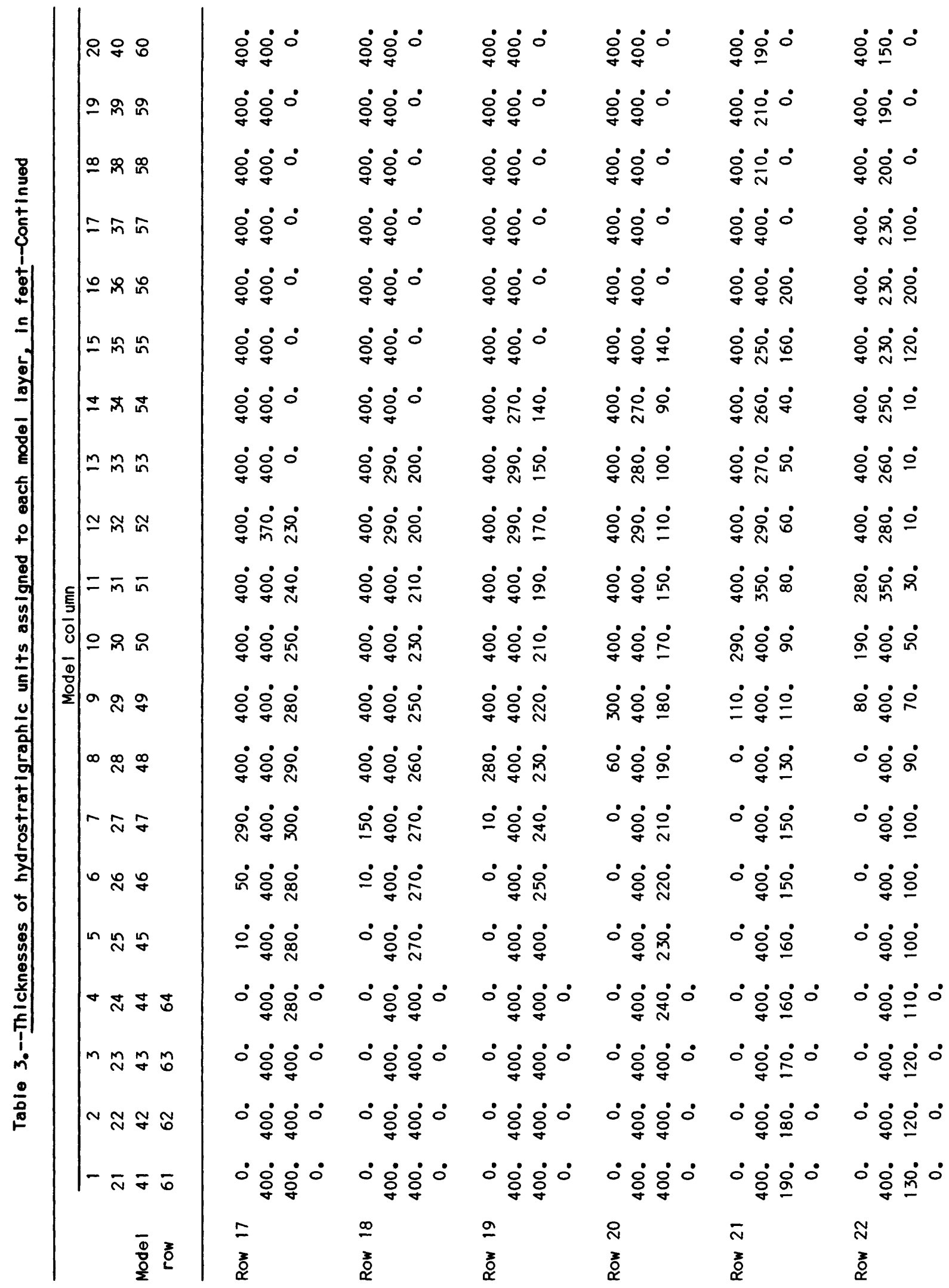




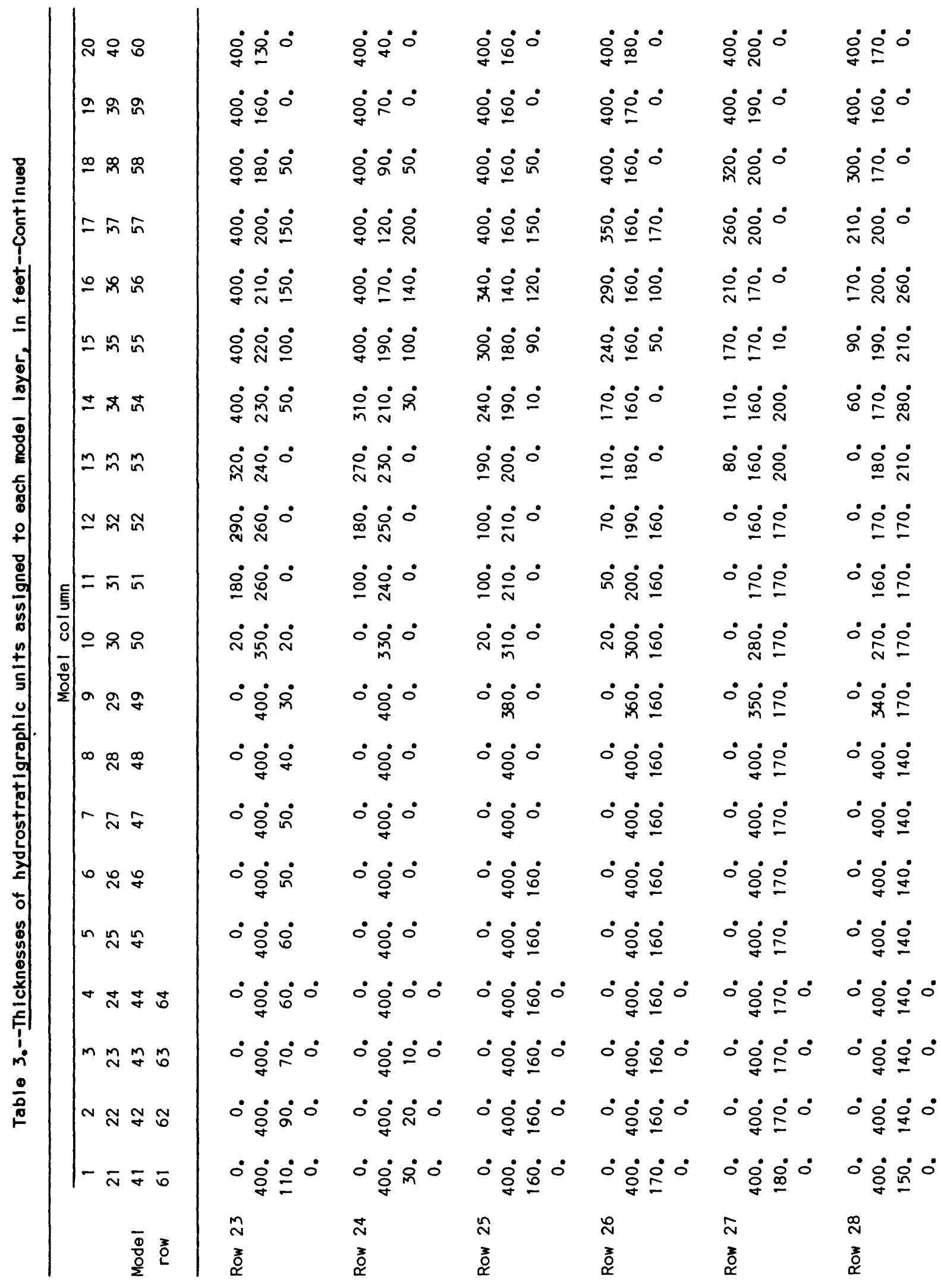




\begin{tabular}{|c|c|c|c|c|c|c|}
\hline i $8:$ & $\dot{g} \dot{\circ} \circ$ & $\dot{8} \dot{\circ} \dot{\circ}$ & $\dot{\circ} \dot{0}$ & $\therefore \therefore$ & $\therefore \therefore$ & $\therefore \therefore$ \\
\hline 용 o & $\dot{8} \dot{\infty} \dot{\infty}$ & $\dot{8} \dot{\circ} \circ$ & $\therefore \circ \dot{0}$ & $\therefore \therefore$ & $\therefore \therefore \circ$ & $\therefore \therefore$ \\
\hline$\infty \nsubseteq \stackrel{\infty}{\infty}$ & $\dot{\circ} \dot{\infty} \dot{\infty}$ & $\dot{p} \dot{q} \dot{\circ}$ & $\therefore \circ \therefore$ & $\therefore \therefore \circ$ & $\therefore \therefore \circ$ & $\therefore \therefore$ \\
\hline$=$ in in & $\dot{0} \dot{\infty} \dot{\infty}$ & $\therefore \dot{\circ}$ & $\therefore \circ$ & $\therefore \circ 0^{\circ}$ & $\therefore \therefore \dot{0}$ & $\therefore \therefore \dot{0}$ \\
\hline 뇨 n̊ & $\stackrel{0}{\underline{D}} \dot{0}$ & $\therefore \dot{\circ}$ & $\therefore \therefore \circ$ & $\therefore \therefore$ & $\therefore \therefore \therefore$ & $\therefore \therefore \dot{0}$ \\
\hline In m nn & $\dot{0} \underset{\infty}{\dot{0}} \dot{0}$ & $\therefore \underset{i}{0} \dot{0}$ & $\therefore \therefore$ & $\therefore \therefore$ & $\dot{0} \dot{0} \dot{0}$ & $\therefore \dot{0}$ \\
\hline D必 & $\therefore \dot{~}$ & $\therefore \stackrel{\circ}{\circ}$ & $\therefore \circ \dot{0}$ & $\therefore \therefore \circ$ & $\dot{0} \therefore \dot{0}$ & $\therefore \therefore \dot{0}$ \\
\hline$m m i n$ & ㅇํㅇ & $\therefore \stackrel{\circ}{\circ}$ & $\therefore$ ஃ̊ㅇ & $\therefore \dot{0}$ & $\therefore \therefore \circ$ & $\dot{0} \dot{0}$ \\
\hline$\simeq \approx N$ & $\therefore \dot{\circ} \dot{\infty}$ & $\therefore \dot{0}$ & $\therefore \dot{\infty} \dot{0}$ & $\therefore \circ \dot{0}$ & $\therefore \dot{0}$ & $\therefore \therefore \dot{0}$ \\
\hline$\underline{\underline{\mid}} \mid=\bar{m} \bar{n}$ & $\dot{\circ} \dot{\circ} \dot{i}$ & $\dot{\circ} \dot{\circ} \dot{g}$ & $\therefore \stackrel{\circ}{\circ}$ & $\therefore \circ \circ$ & $\therefore \circ:$ & $\therefore \dot{0}$ \\
\hline 잉으 요 요 & $\therefore \underset{\sim}{\dot{2}}$ & $\dot{\circ} \dot{\circ} \dot{p}$ & $\therefore \dot{0}$ & $\therefore \therefore \circ$ & $\therefore \circ:$ & $\therefore 0^{\circ}$ \\
\hline 월 & $\therefore \dot{0} \dot{0} \dot{\infty}$ & $\therefore \dot{0} \dot{0}$ & $\therefore \dot{0}$ & $\dot{\circ} \dot{\circ} \dot{0}$ & $\therefore \circ 0^{\circ}$ & $\therefore \circ 0$ \\
\hline$\infty \stackrel{\infty}{\sim} \stackrel{\infty}{+}$ & ○ & $\therefore \dot{0}$ & $\dot{0} \dot{p} \dot{0}$ & $\therefore \dot{\circ}$ & $\therefore \underset{\infty}{\dot{0}} \dot{0}$ & $\therefore \therefore \circ$ \\
\hline$n \approx F$ & $\dot{\circ} \dot{\circ} \dot{\infty}$ & $\dot{\circ} \dot{g} \dot{q}$ & $\therefore$ 遍 & $\therefore \circ$ & $\therefore \underset{\infty}{\dot{0}} \dot{0}$ & $\therefore \circ \circ$ \\
\hline $0 \stackrel{2}{2}$ & ○ $\dot{\circ} \dot{\infty}$ & $\therefore \dot{\circ} \dot{q}$ & $\therefore \dot{\circ}$ & $\therefore \circ$ & $\therefore \underset{\infty}{\circ} 0^{\circ}$ & $\dot{\circ} \underset{\infty}{\dot{0}} \dot{0}$ \\
\hline 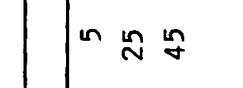 & $\dot{\circ} \dot{8} \dot{\infty}$ & $\dot{\circ} \dot{\circ} \dot{q}$ & $\therefore \frac{0}{m} \dot{0}$ & $\therefore \dot{\sim}$ & $\therefore \underset{\infty}{\circ} \dot{0}$ & $\therefore \underset{\infty}{\circ} \dot{0}$ \\
\hline 舫过 & $\dot{\circ} \dot{8} \dot{\infty} \dot{\circ}$ & $\dot{\circ} \dot{8} \dot{q} \dot{\circ}$ & $\therefore \frac{0}{m} \dot{\circ}$ & $\dot{\circ} \dot{\circ} \circ$ & $\therefore \underset{\infty}{\circ} 0^{\circ} \circ$ & $\therefore \circ 0^{\circ}$ \\
\hline$m \stackrel{\sim}{\sim} \underset{b}{m}$ & $\dot{\circ} \dot{\delta} \dot{8} \dot{\infty}$ & $\dot{\circ} \dot{8} \dot{q} \dot{q}$ & $\dot{\circ} \dot{8} \dot{0} \dot{\circ}$ & $\dot{\circ} \underset{\mathrm{o}}{0} \dot{\circ}$ & $\therefore \circ \dot{\circ}$ & $\dot{\circ} \dot{\circ} \dot{0}$ \\
\hline$\sim \approx \mathcal{N}$ & $\dot{\circ} \dot{8} \dot{\delta} \dot{\infty}$ & $\dot{\circ} \dot{8} \dot{q} \dot{\circ}$ & $\therefore$ ○் & $\dot{\circ} \dot{\circ} \dot{\circ}$ & $\dot{0} \dot{\circ} \dot{0}$ & $\therefore \circ \circ \circ$ \\
\hline$-\bar{N} \bar{\sigma}$ & $\dot{\circ} \dot{8} \dot{\infty} \dot{\circ}$ & $\dot{\circ} \dot{8} \dot{q} \dot{\circ}$ & $\dot{\circ} \frac{\dot{0}}{\mathrm{O}} \dot{\circ}$ & $\therefore \therefore \therefore$ & $\therefore \circ \dot{\circ}$ & $\dot{\circ} \dot{\circ} \dot{\circ}$ \\
\hline & 2 & 요 & $\bar{m}$ & $\tilde{m}$ & $\tilde{m}$ & क \\
\hline & $\stackrel{7}{\alpha}$ & \& & $\stackrel{z}{\alpha}_{\alpha}^{z}$ & $\underset{\alpha}{z}$ & $\begin{array}{l}z \\
0 \\
\alpha\end{array}$ & वे \\
\hline
\end{tabular}




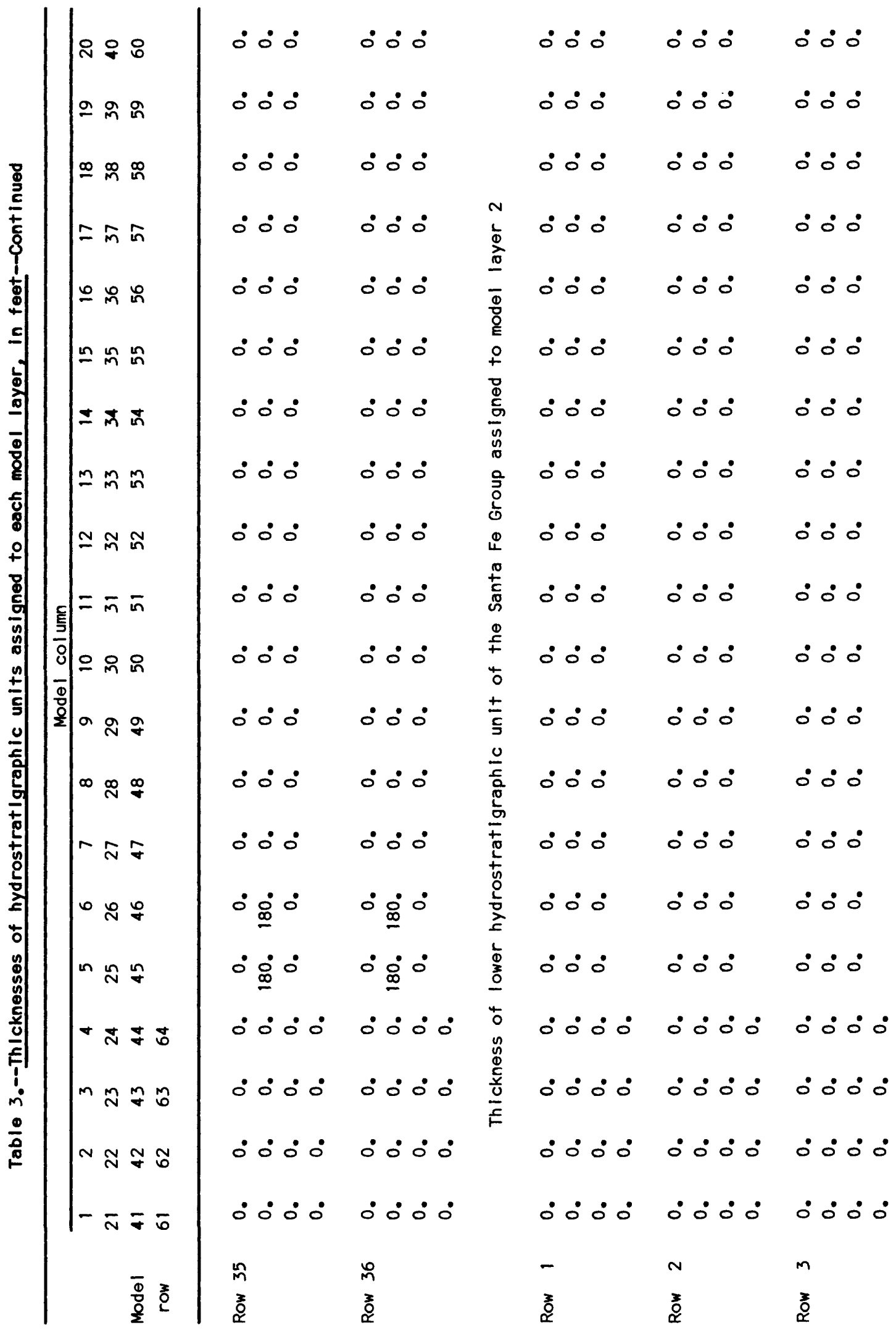




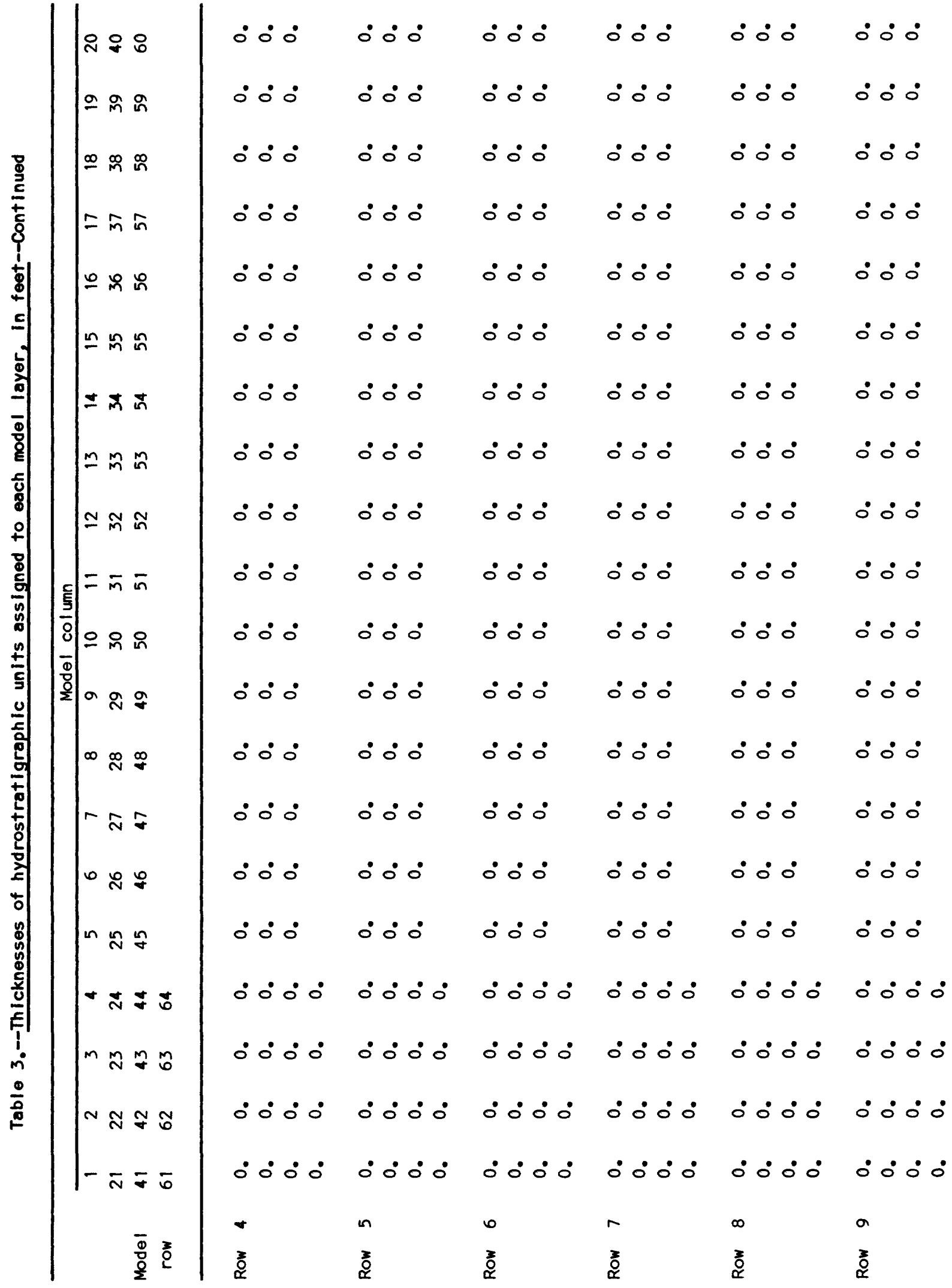




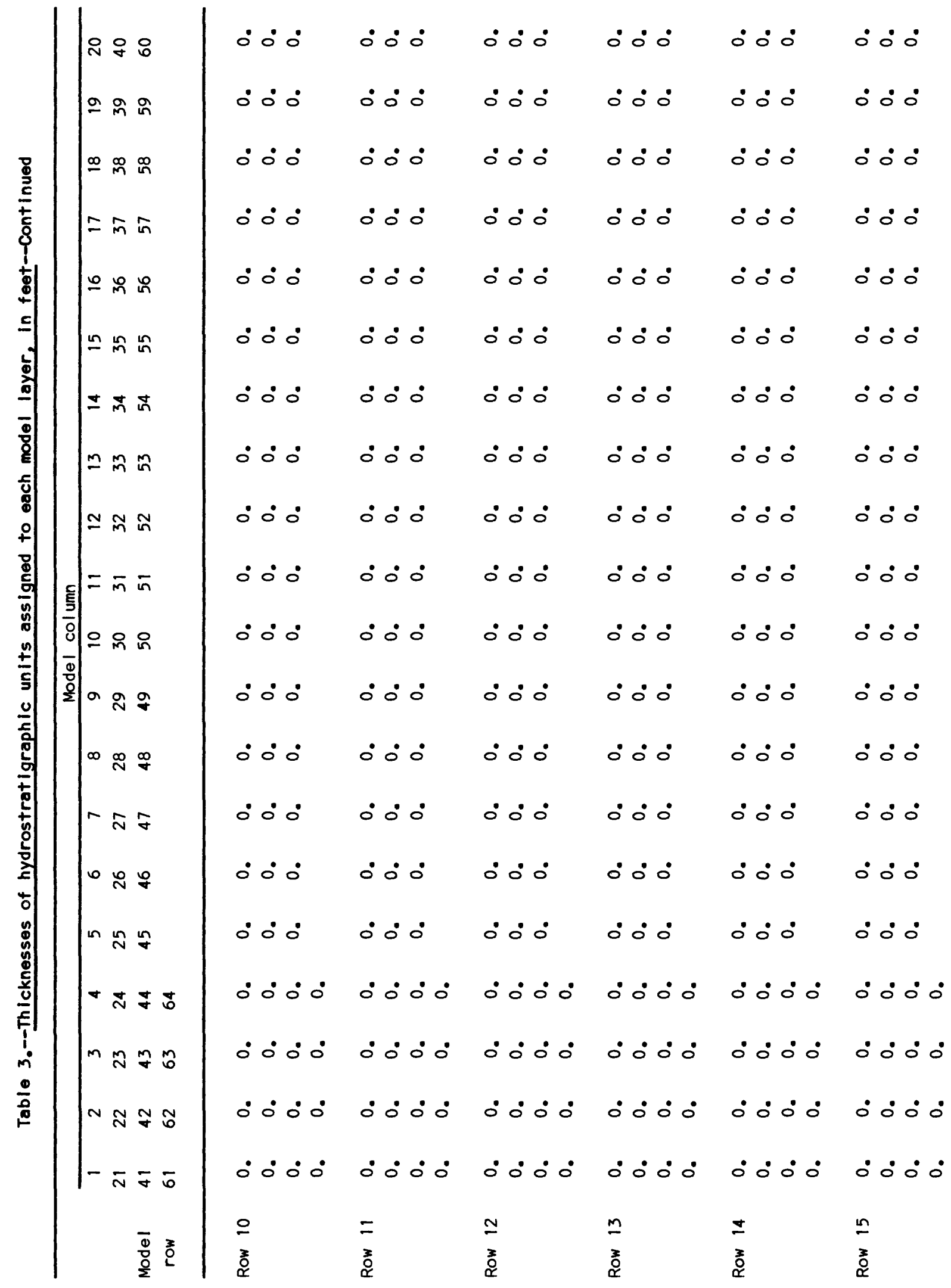




\begin{tabular}{|c|c|c|c|c|c|c|}
\hline 용ㅇㅇ & $\therefore \therefore$ & $\therefore \therefore 0$ & $\therefore \therefore \circ$ & $\therefore \therefore$ & $\therefore \therefore \dot{0}$ & $\therefore \therefore \dot{0}$ \\
\hline 욜 & $\therefore \therefore$ & $\therefore \therefore \circ$ & $\therefore \therefore \circ$ & $\therefore \circ \dot{0}$ & $\therefore \circ \therefore$ & $\therefore \circ:$ \\
\hline @ & $\therefore \therefore$ & $\therefore \therefore \dot{0}$ & $\therefore \therefore \circ$ & $\therefore \therefore$ & $\therefore \therefore \dot{0}$ & $\therefore \therefore$ \\
\hline$=\bar{m}$ in & $\therefore 0^{\circ}$ & $\therefore \circ \dot{0}$ & $\therefore \therefore \circ$ & $\therefore \therefore$ & $\therefore \therefore$ & $\therefore \therefore$ \\
\hline 응 & $\therefore \dot{0}$ & $\therefore \circ 0^{\circ}$ & $\therefore \therefore \circ$ & $\therefore \dot{0}$ & $\therefore \dot{0}$ & $\therefore \therefore$ \\
\hline 등 & $\therefore \therefore$ & $\therefore \circ \dot{0}$ & $\therefore \therefore \circ$ & $\therefore \dot{0}$ & $\therefore \therefore$ & $\therefore \therefore \circ$ \\
\hline \pm 式 & $\therefore \dot{0}$ & $\therefore \therefore \circ$ & $\therefore \therefore \therefore$ & $\therefore \therefore$ & $\therefore \therefore$ & $\therefore \therefore$ \\
\hline$m m \tilde{n}$ & $\therefore \circ \dot{0}$ & $\therefore \circ \dot{0}$ & $\therefore \circ \dot{0}$ & $\dot{0} \dot{\circ}$ & $\therefore \circ \dot{0}$ & $\therefore \circ:$ \\
\hline$\simeq \approx \sim ⿻ 上 丨$ & $\therefore \dot{0}$ & $\therefore \circ \dot{0}$ & $\therefore \therefore$ & $\therefore \therefore \circ$ & $\therefore \dot{0}$ & $\dot{0} \dot{0}$ \\
\hline$\underline{f}=\bar{m} \bar{n}$ & $\therefore \therefore$ & $\therefore \dot{0}$ & $\therefore \circ \dot{0}$ & $\therefore \circ \dot{0}$ & $\therefore \circ \dot{0}$ & $\therefore \dot{0}$ \\
\hline$\frac{8}{0} \mid 0$ 응 요 & $\therefore \circ \dot{0}$ & $\therefore \circ \dot{0}$ & $\therefore \circ \dot{0}$ & $\therefore \circ \dot{0}$ & $\therefore \therefore \dot{0}$ & $\stackrel{0}{\circ} \dot{0}$ \\
\hline 일 & $\therefore \circ \dot{0}$ & $\therefore \circ \circ$ & $\therefore \circ$ & $\therefore \circ 0^{\circ}$ & $\dot{0} 00$ & ن্ं \\
\hline$\infty \underset{\sim}{\infty} \stackrel{\infty}{q}$ & $\therefore \circ$ & 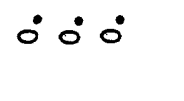 & $\therefore \circ \dot{0}$ & فํ & $\dot{0} \circ$ & $\dot{i} \dot{\circ}$ \\
\hline$-\tilde{N}=$ & $\therefore \circ \dot{0}$ & $\therefore \circ 0^{\circ}$ & $\dot{\mathrm{N}} \dot{\circ} \dot{0}$ & $\therefore \circ 0^{\circ}$ & $\therefore \circ \dot{0}$ & $\therefore \therefore \circ$ \\
\hline $0 \%$ & $\therefore \therefore$ & $\dot{0} \dot{0}$ & $\therefore \therefore$ & $\therefore \therefore$ & $\therefore \circ \dot{0}$ & $\dot{0} \dot{0} \dot{0}$ \\
\hline $\ln \stackrel{n}{n}$ & $\therefore \dot{0}$ & $0^{\circ} 0^{\circ}$ & $\therefore \therefore \circ$ & $\therefore 0^{\circ}$ & $\therefore \circ \dot{0}$ & $\therefore \circ 0^{\circ}$ \\
\hline 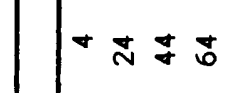 & $\dot{0} \dot{\circ} \dot{0}$ & $\dot{\circ} \dot{\circ} \dot{\circ} \dot{0}$ & $\dot{\circ} \therefore \dot{0}$ & $\therefore \circ \dot{\circ}$ & $\dot{\circ} \dot{0} \dot{\circ}$ & $\dot{0} \dot{\circ} \dot{\circ}$ \\
\hline$m \approx m$ & $\dot{\circ} \div \circ$ & $\dot{\circ} \dot{\circ} \dot{\circ}$ & $\therefore \circ \dot{\circ} \dot{\circ}$ & $\therefore \dot{\circ} \dot{\circ}$ & $\dot{\circ} \dot{\circ} \dot{\circ}$ & $\dot{\circ} \dot{\circ} \dot{\circ}$ \\
\hline$\sim \mathcal{N}$ ก & $\therefore \therefore \circ$ & $\therefore \therefore \dot{0}$ & $\dot{\circ} \dot{\circ} \dot{\circ}$ & $\dot{\circ} \dot{\circ} \dot{\circ}$ & $\therefore \therefore \dot{0}$ & $\dot{\circ} \therefore 0^{\circ}$ \\
\hline |ーデテテ & $\therefore \circ \therefore \circ$ & $\therefore \circ 0^{\circ}$ & $\therefore \therefore \dot{0}$ & $\therefore \circ \therefore$ & $\therefore \therefore \therefore$ & $\therefore \therefore 0^{\circ}$ \\
\hline & $\cong$ & $=$ & 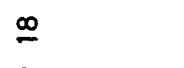 & $\underline{9}$ & i & $\bar{N}$ \\
\hline$\frac{0}{2}$ & $\stackrel{3}{\alpha}_{\alpha}^{z}$ & $\underset{\alpha}{3}$ & $\underset{\alpha}{2}$ & $\begin{array}{l}\frac{\pi}{\alpha} \\
\alpha \\
\alpha\end{array}$ & $\underset{\substack{z \\
\alpha}}{0}$ & $\begin{array}{l}z \\
\alpha \\
\alpha\end{array}$ \\
\hline
\end{tabular}




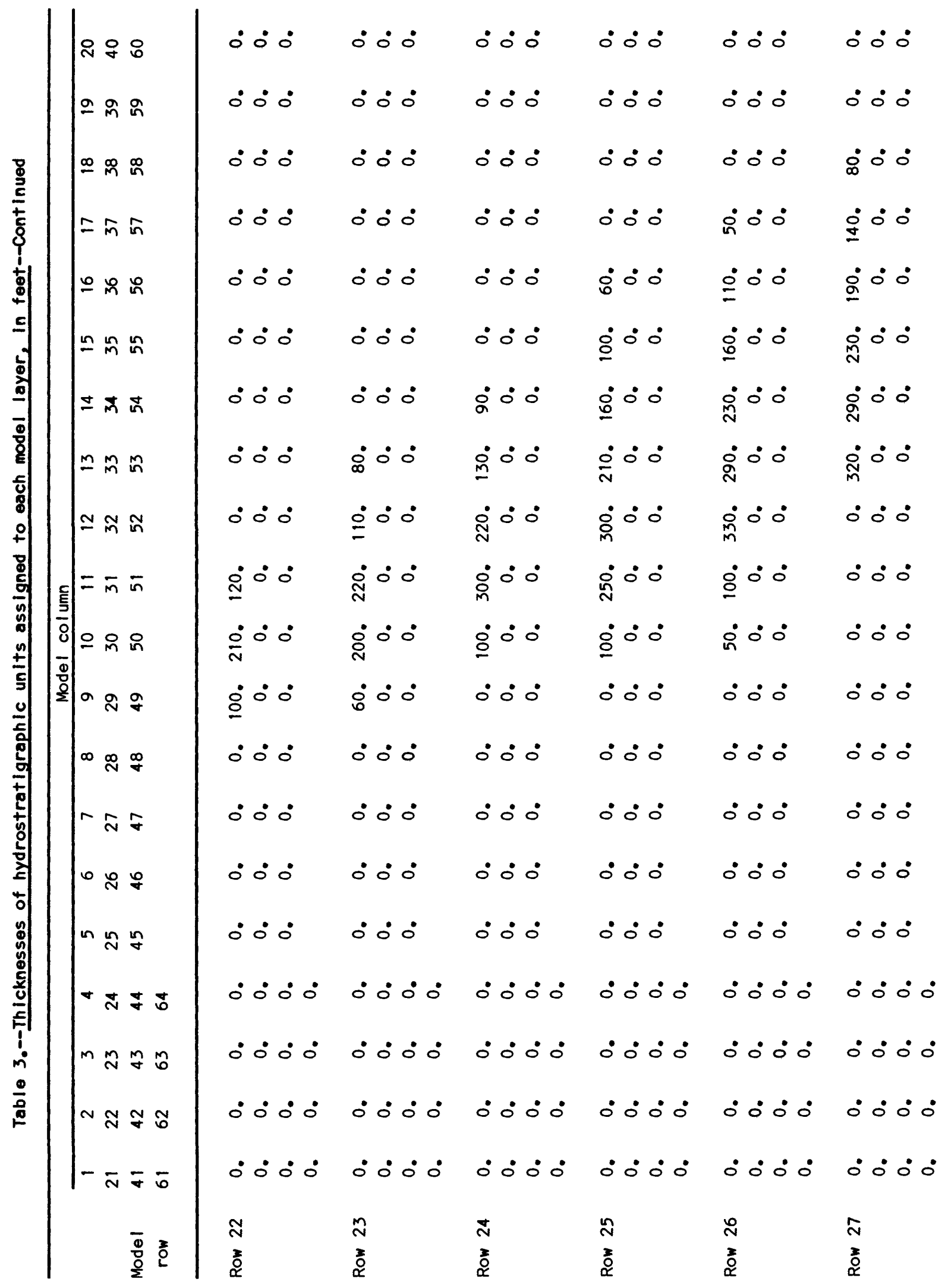




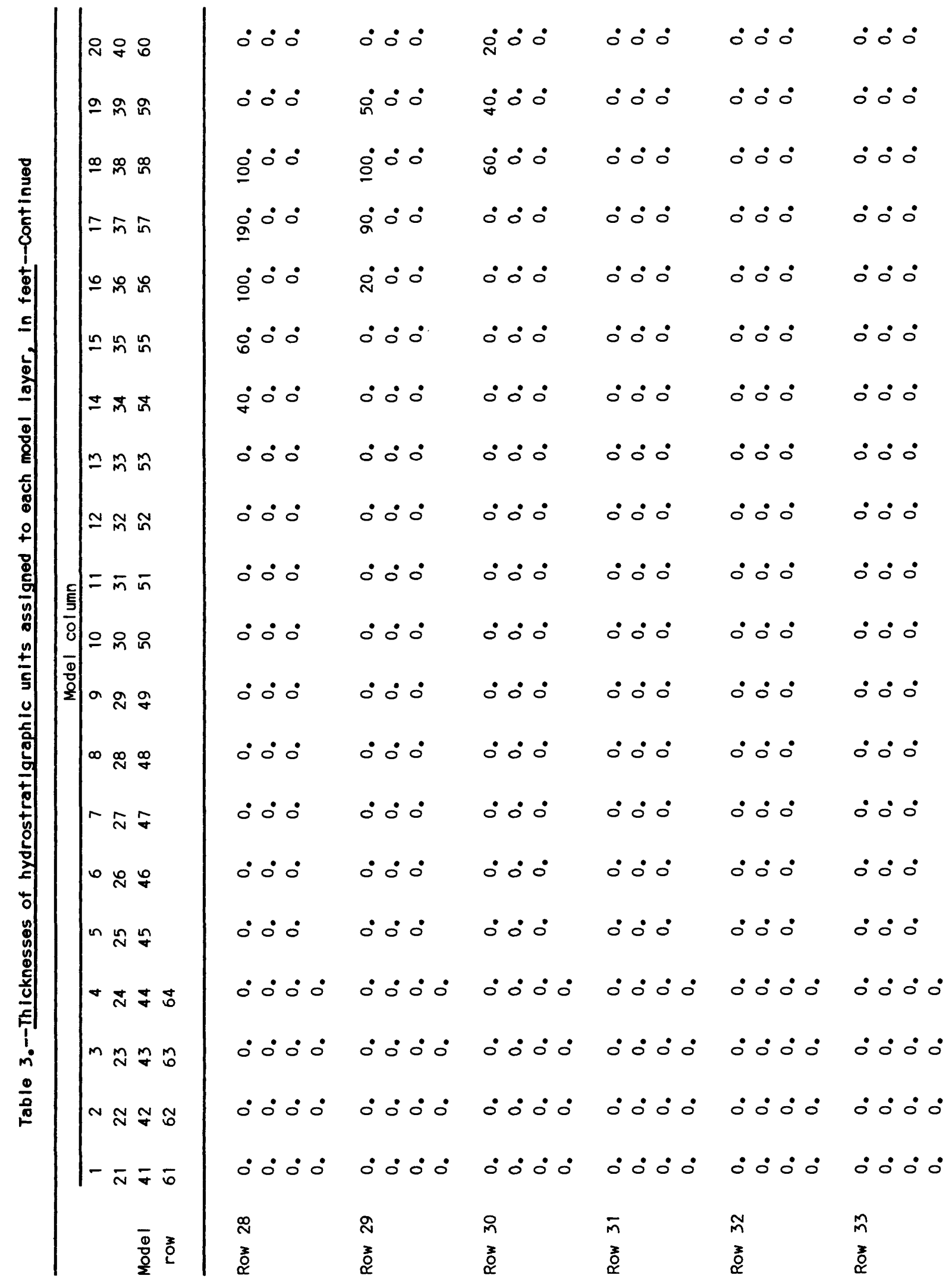




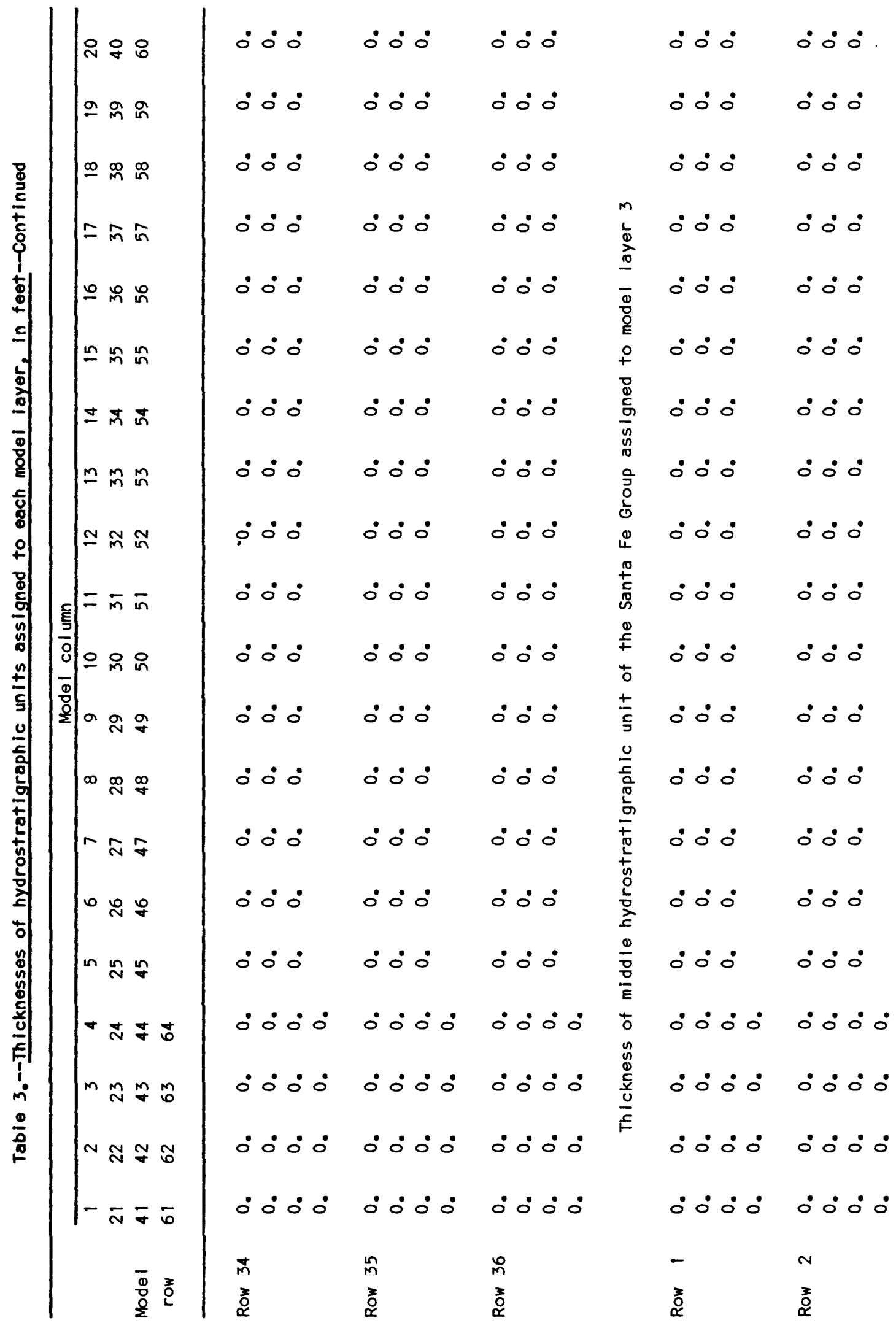




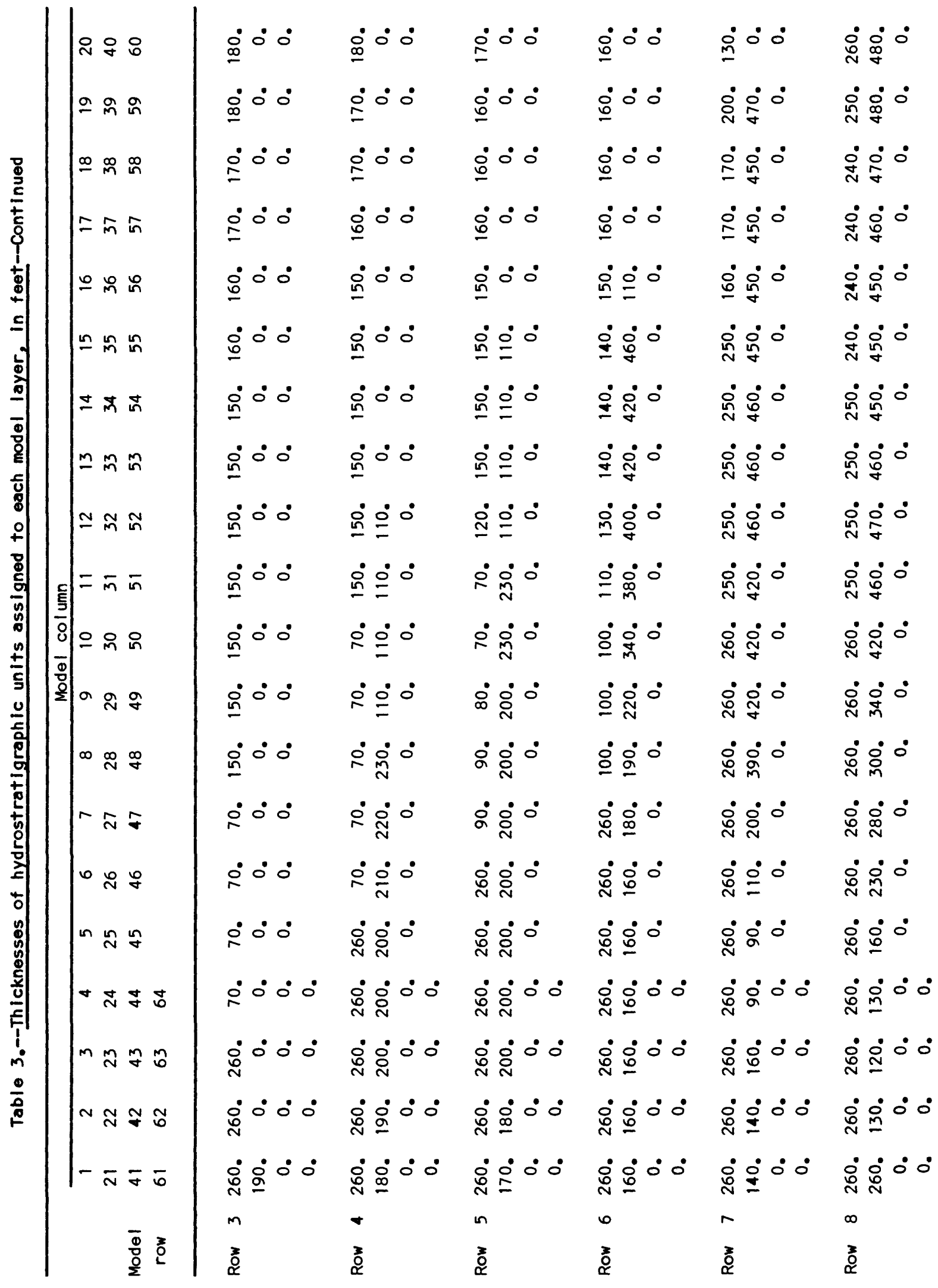




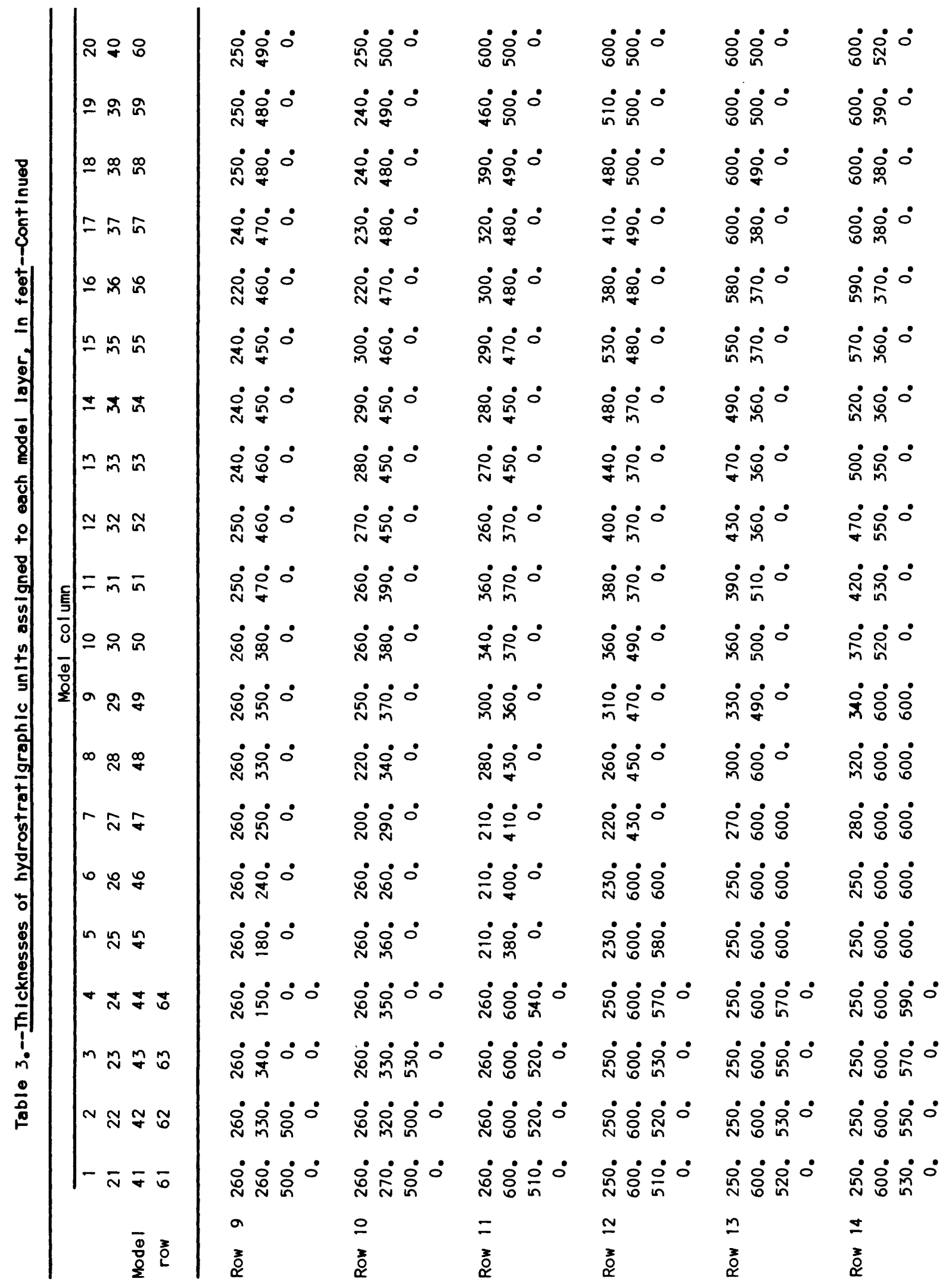




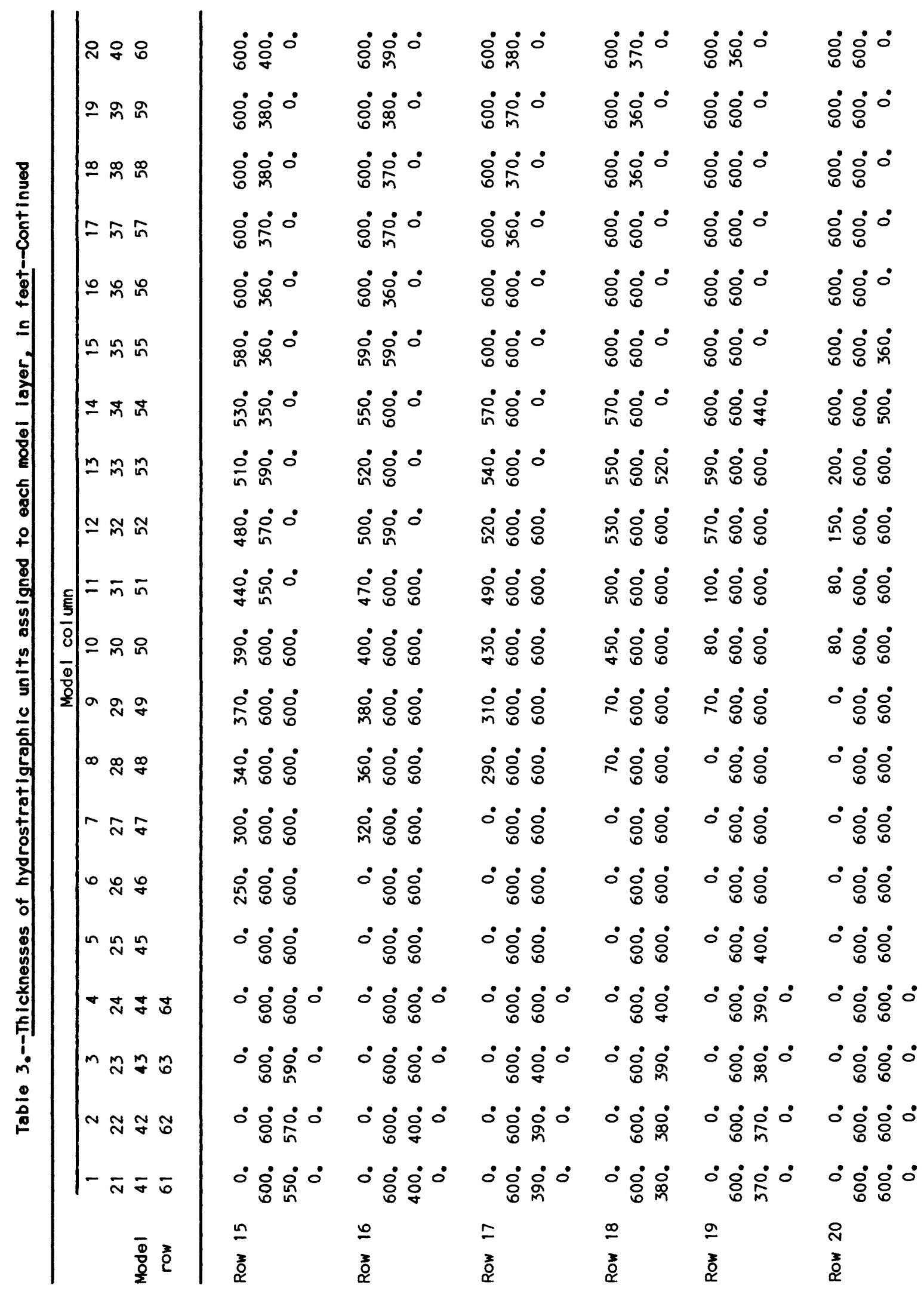




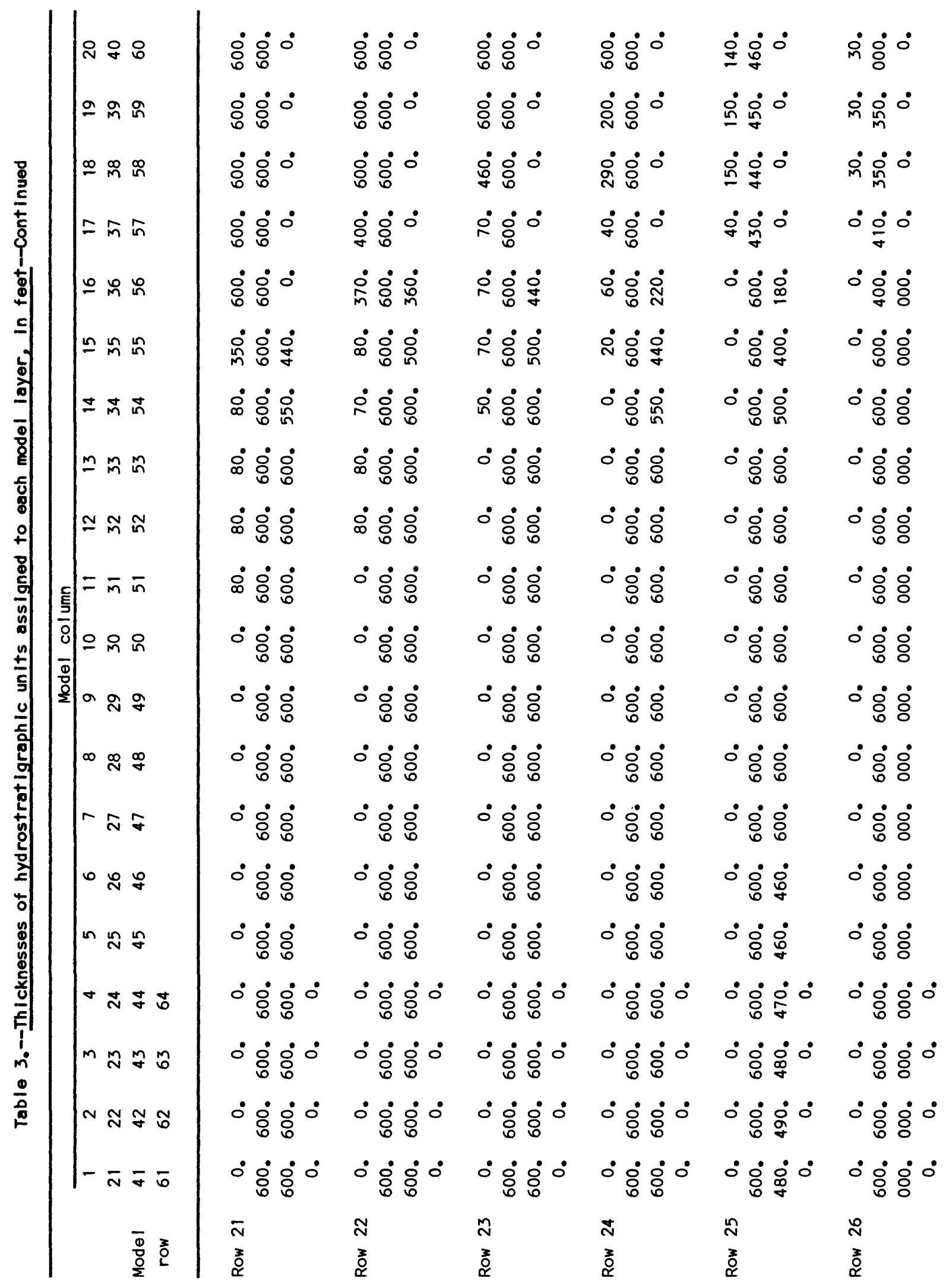




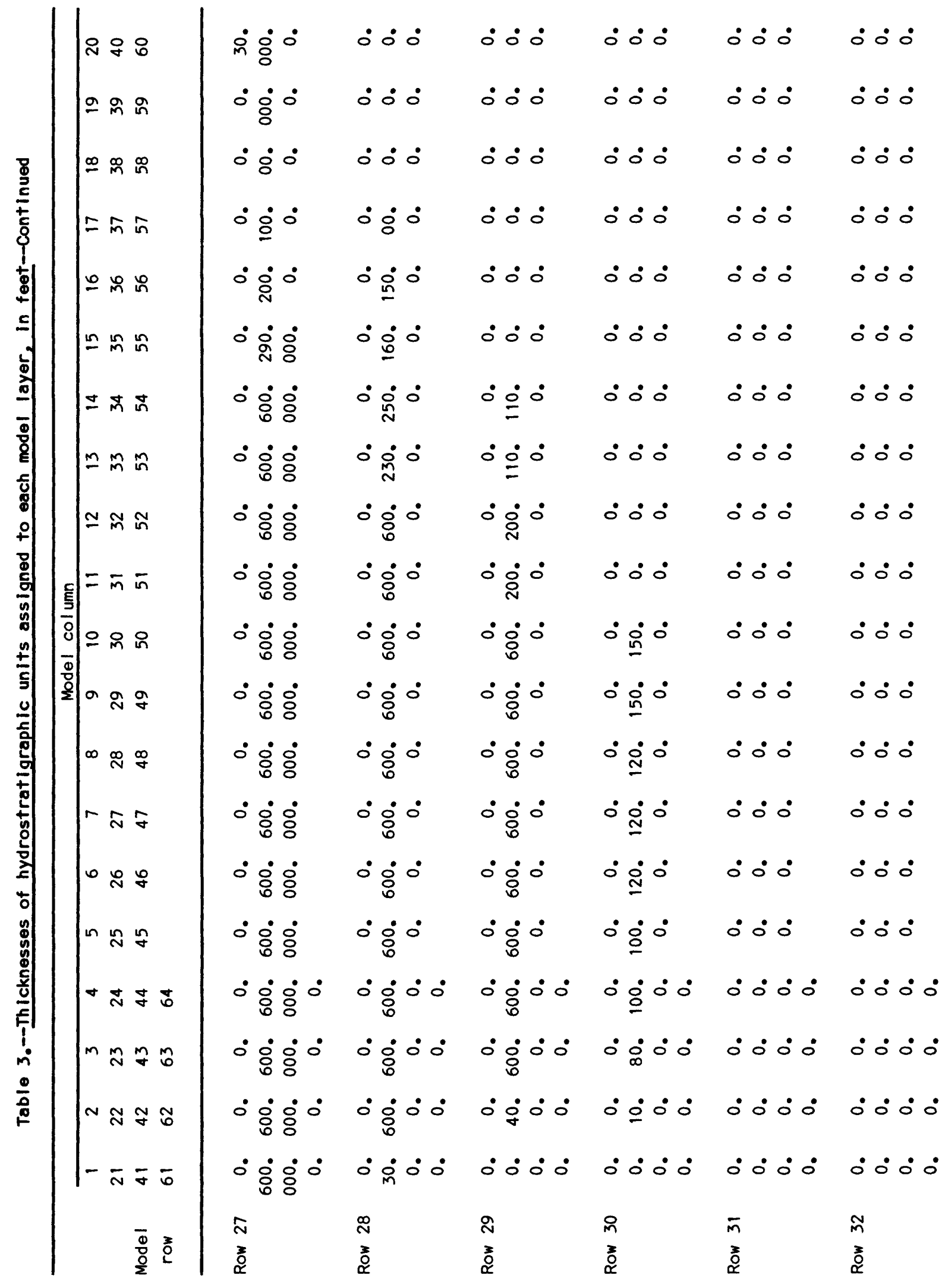




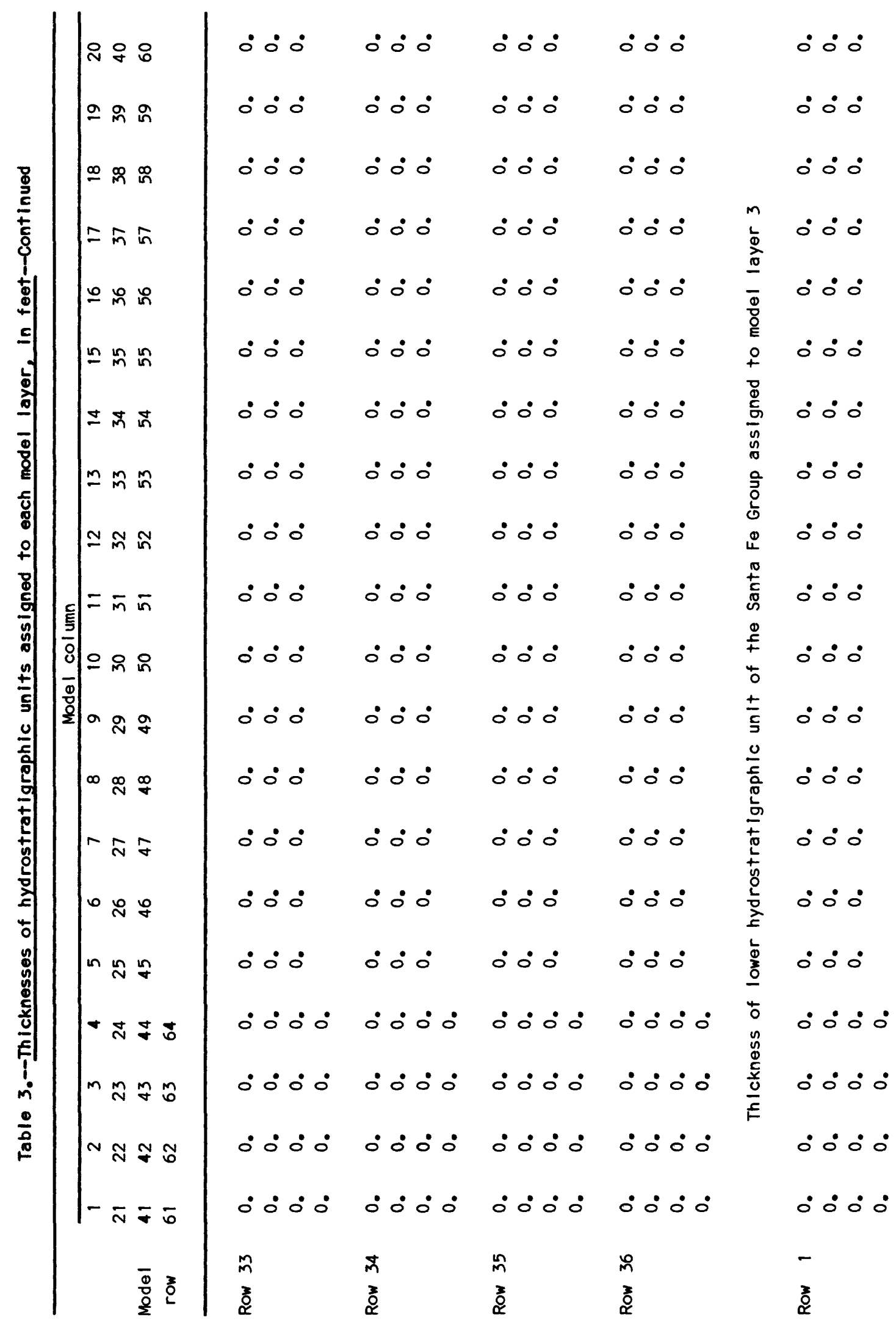




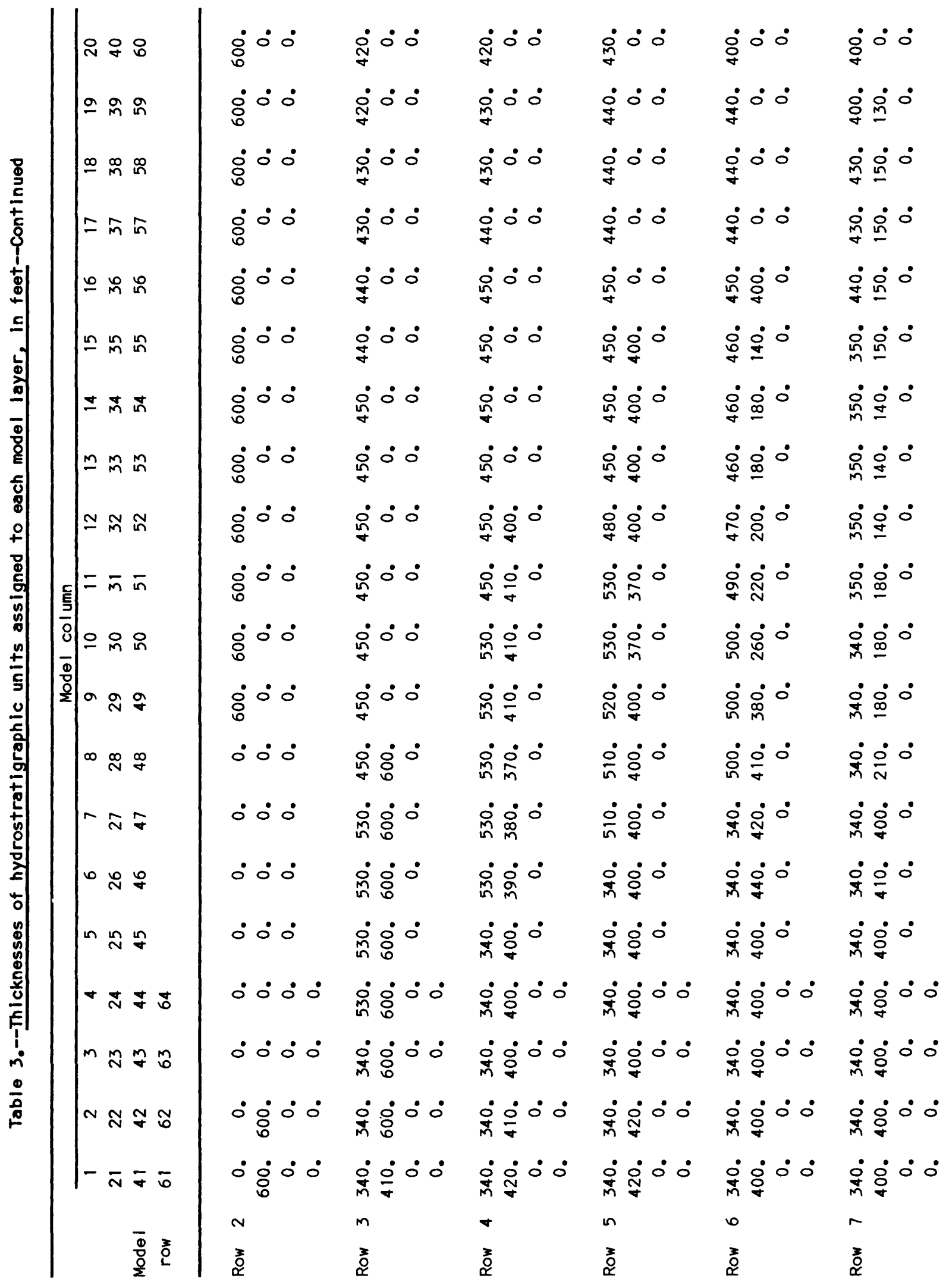




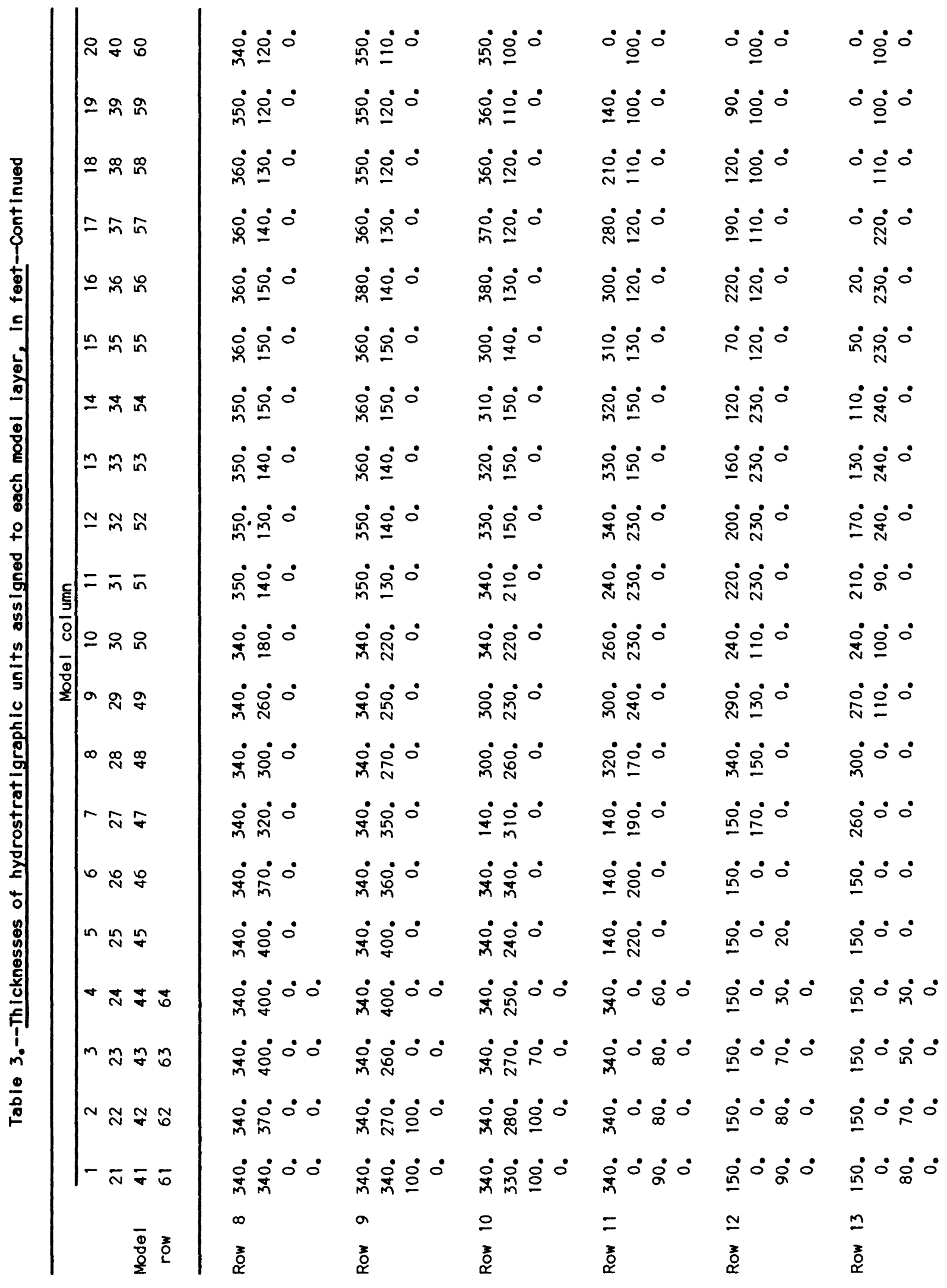




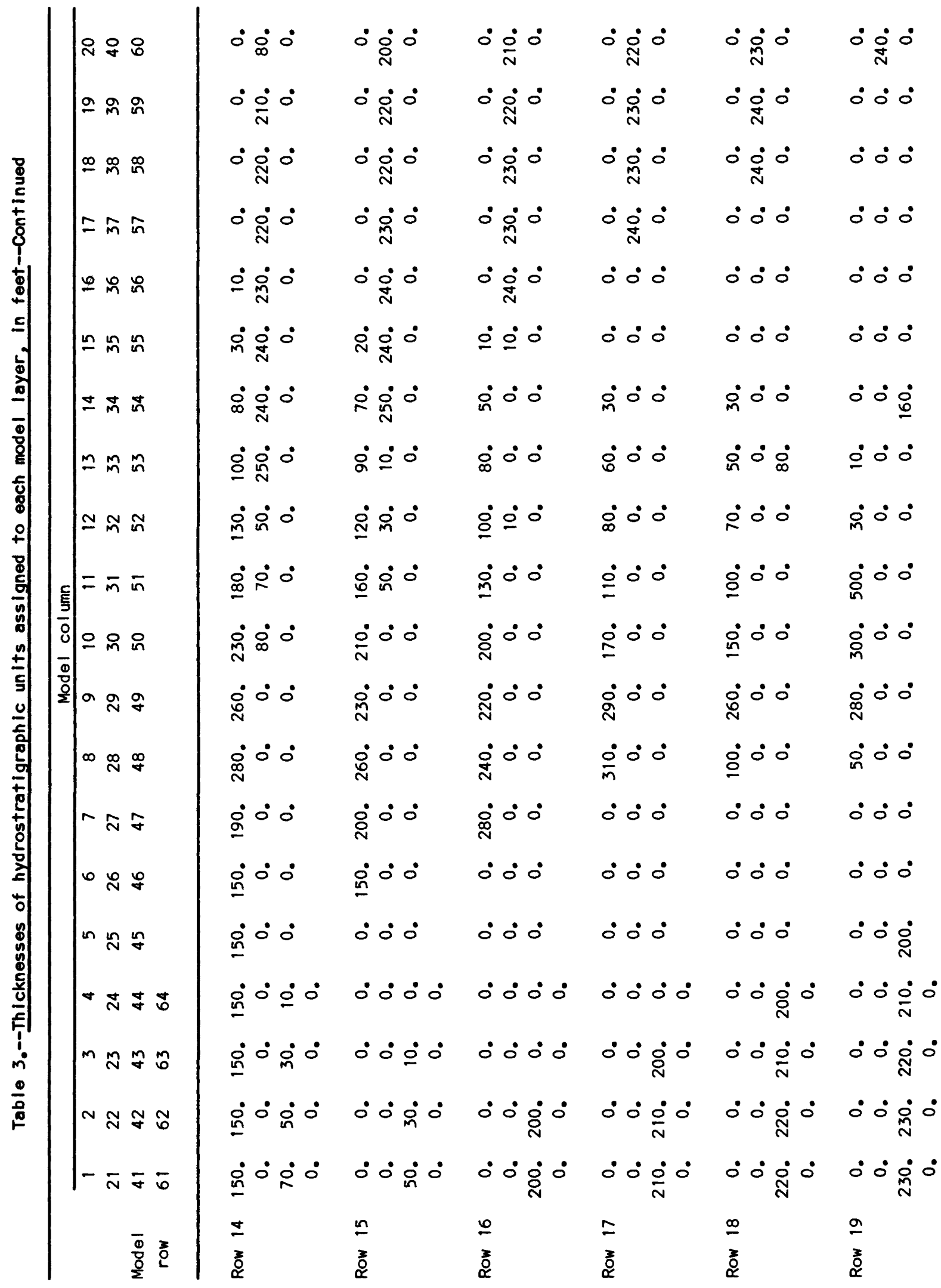




\begin{tabular}{|c|c|c|c|c|c|c|}
\hline 웅 & $\therefore \therefore \dot{0}$ & $\therefore \therefore \dot{0}$ & $\therefore \circ \therefore$ & $\therefore \circ \therefore$ & $\therefore \circ \therefore$ & $\dot{0} \dot{0} \dot{0}$ \\
\hline 응 & $\therefore \therefore$ & $\therefore \therefore \dot{0}$ & $\therefore \therefore$ & $\therefore \circ 0^{\circ}$ & $\dot{8}: 0$ & வ் \\
\hline 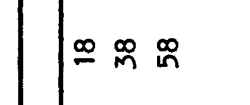 & $\therefore \therefore$ & $\therefore \circ 0^{\circ}$ & $\therefore \circ:$ & $\dot{0} \div 0$ & $\frac{\dot{0}}{m} \circ$ & வூல் \\
\hline$=n$ in & $\therefore \therefore$ & $\therefore \therefore 0$ & $\dot{8} 0$ ○ & în & 通 & 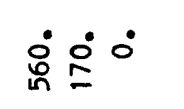 \\
\hline 으 ํํํ ํำ & $\therefore \therefore$ & $\therefore \circ \stackrel{8}{\circ}$ & i্j $0 \dot{d}$ & 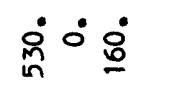 & 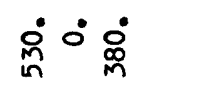 & 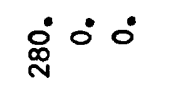 \\
\hline In m nn & $\therefore \therefore \frac{d}{d}$ & : & $\dot{\check{n}}$ & iñ & $\dot{8} \therefore$ & வ் \\
\hline 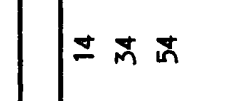 & $\therefore \therefore \dot{0}$ & $\dot{i n ் ~}$ & î̉ & î̉ & ஓृं & $\dot{j} \dot{0} \dot{0}$ \\
\hline$m m \tilde{m}$ & $\dot{8} \circ 0^{\circ}$ & $\frac{\dot{0}}{0} \dot{0}$ & ஓं & $\dot{\leftrightarrow} \dot{0}$ & : & $\dot{j}: \circ$ \\
\hline$\simeq \approx \tilde{N}$ in & ஜุ & ஒ্ণ் & $\dot{8} \dot{8} \circ$ & ه্ল $0^{\circ}$ & 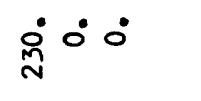 & $\stackrel{\circ}{\circ} \circ$ \\
\hline$\underline{\mathrm{f}}=\overline{\mathrm{n}} \overline{\mathrm{n}}$ & $\dot{\circ} 0$ & $\dot{\infty} \underset{m}{\dot{0}} \dot{0}$ & $\dot{8} \dot{0} \circ$ & $\dot{0} 0 \dot{0}$ & $\dot{2} \circ \dot{0}$ & $\therefore \therefore:$ \\
\hline 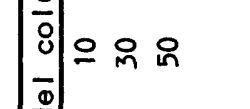 & $\frac{\circ}{m} \circ$ & $\dot{8} \dot{0}$ & ஜ் $0 \dot{0}$ & $\therefore \circ \therefore$ & $\therefore \circ 0^{\circ}$ & $\therefore \therefore \circ$ \\
\hline 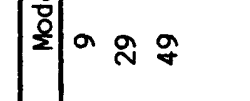 & $\dot{0} \circ 0$ & $\therefore 0^{\circ}$ & $\therefore \circ \therefore$ & $\therefore \circ:$ & $\therefore 0^{\circ}$ & $\therefore: 0$ \\
\hline$\infty \underset{\sim}{\infty}$ & $\therefore \circ \dot{0}$ & $\therefore \therefore \circ$ & $\therefore \therefore$ & $\therefore \therefore$ & $\therefore \therefore \circ$ & $\therefore \circ$ \\
\hline$-\approx=$ & $\therefore \therefore$ & $\therefore \circ:$ & $\therefore \therefore$ & $\therefore \therefore$ & $\therefore \therefore$ & $0^{\circ}$ \\
\hline $02 \%$ & $\therefore \therefore \circ$ & $\therefore \therefore$ & $\therefore \therefore$ & $\therefore \therefore$ & $\therefore \therefore \circ$ & $\therefore \therefore \dot{0}$ \\
\hline $\operatorname{nn} 2$ & $\therefore \therefore \circ$ & $\therefore \therefore \circ$ & $\therefore \therefore \circ$ & $\therefore \therefore$ & $\therefore \therefore \circ$ & $\therefore \dot{0}$ \\
\hline 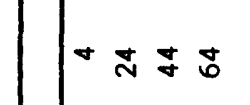 & $\therefore \circ \therefore \circ$ & $\therefore \therefore \circ \therefore$ & $\therefore \therefore \therefore$ & $\therefore \circ 0^{\circ}$ & $\therefore \therefore \therefore$ & $\therefore \therefore \stackrel{\circ}{0} \dot{0}$ \\
\hline$m \approx n$ & $\therefore \therefore \circ \dot{0}$ & $\therefore \therefore \therefore$ & $\therefore \circ \therefore$ & $\therefore \circ 0^{\circ}$ & $\therefore \therefore \therefore$ & $\therefore \therefore \dot{0}$ \\
\hline $\operatorname{N} \approx * \frac{7}{4}$ & $\therefore \therefore \therefore$ & $\therefore \therefore \therefore$ & $\therefore \therefore \therefore$ & $\therefore \circ \therefore$ & $\therefore \therefore \therefore$ & $\therefore \therefore \bigcirc$ \\
\hline $\mid-\bar{N} \bar{\sigma}$ & $\therefore \therefore \therefore$ & $\therefore \therefore \therefore$ & $\therefore \therefore \therefore$ & $\therefore \circ \therefore$ & $\therefore \therefore \therefore$ & $\therefore \therefore \stackrel{0}{\circ}$ \\
\hline & i & $\bar{N}$ & N & $\stackrel{m}{\sim}$ & I & (1) \\
\hline 送 & $\stackrel{z}{\alpha}_{\alpha}^{z}$ & $\stackrel{2}{z}$ & 产 & $\frac{7}{\alpha}$ & $\stackrel{3}{\alpha}$ & ?. \\
\hline
\end{tabular}




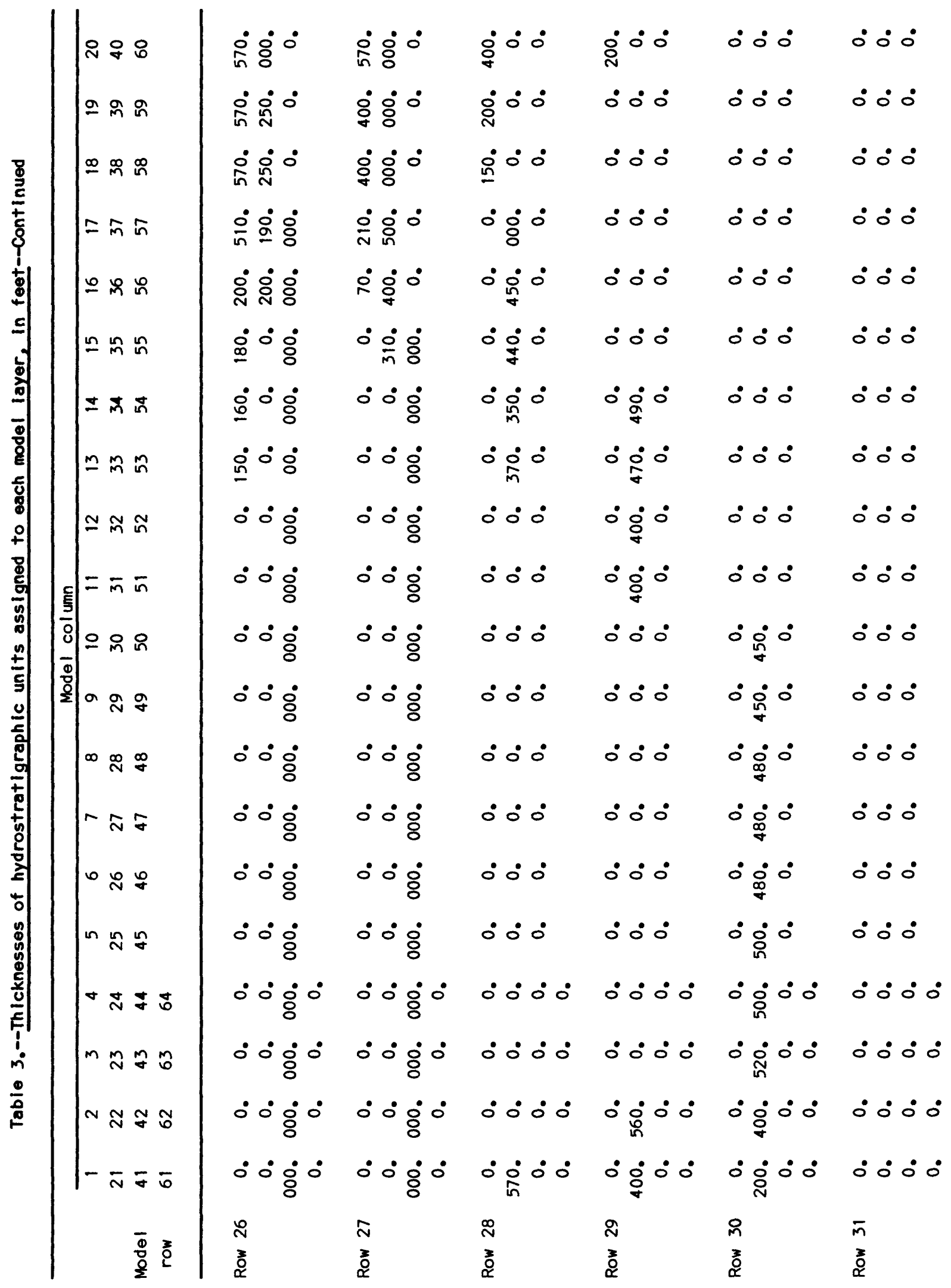




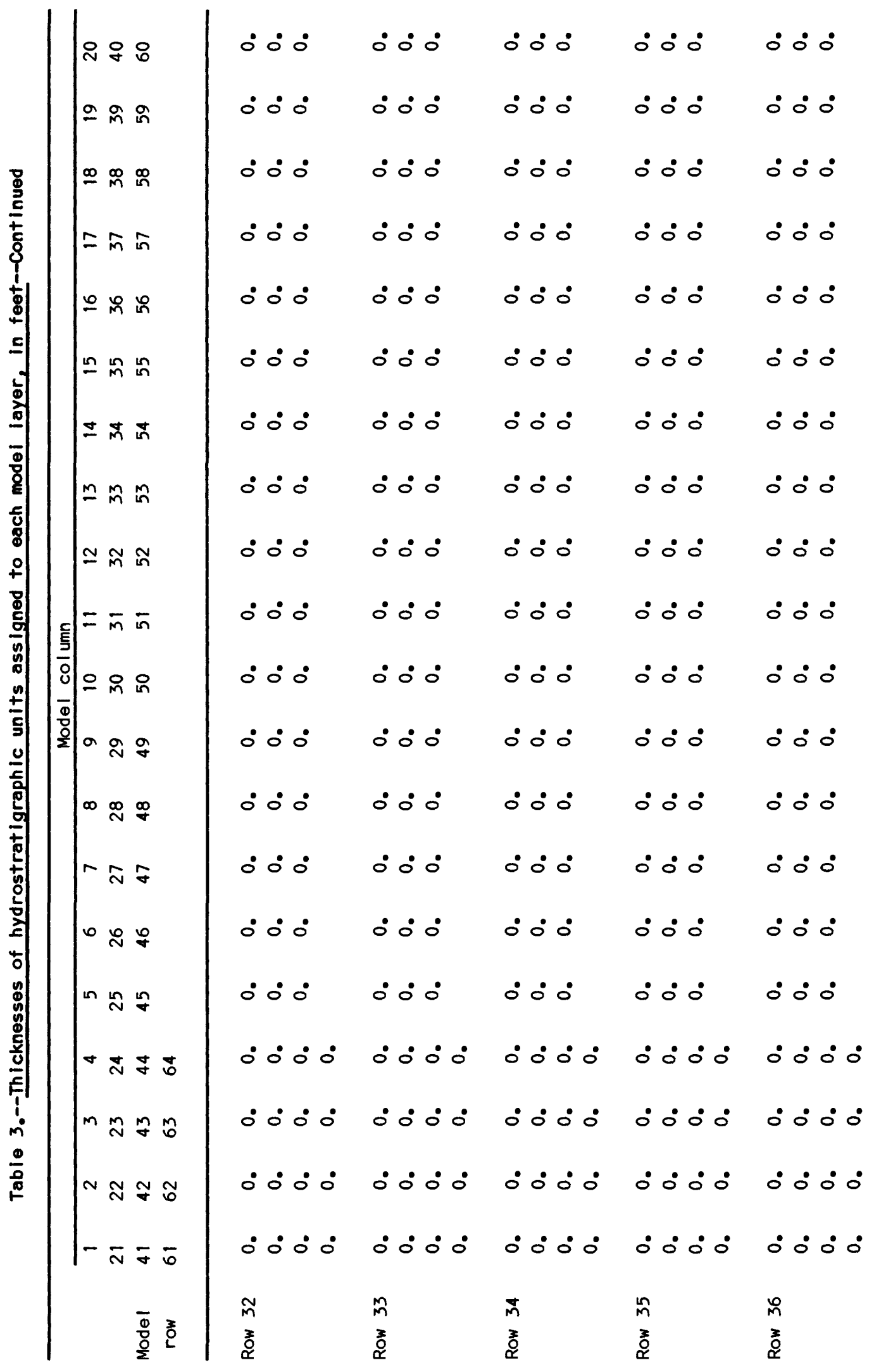




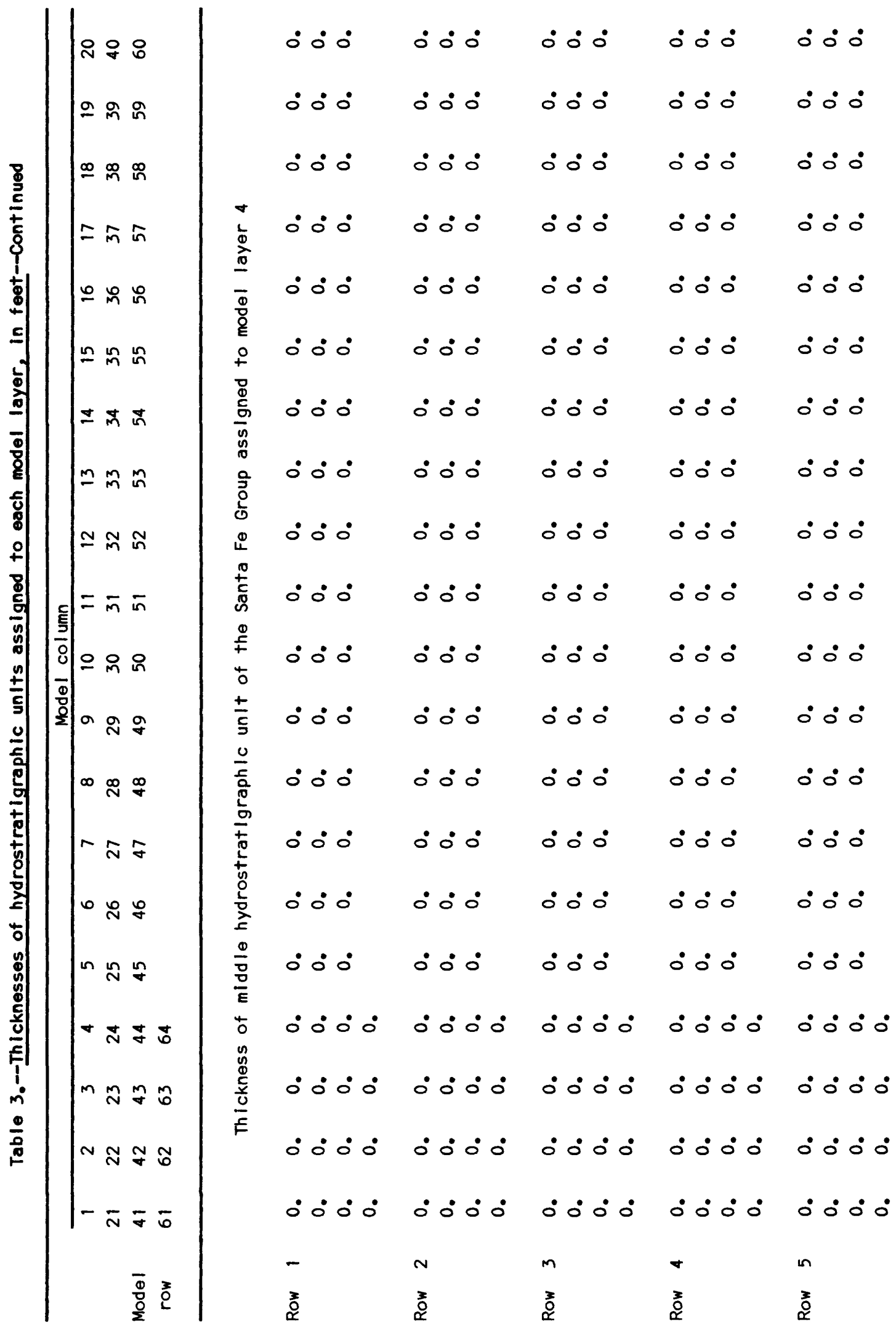




\begin{tabular}{|c|c|c|c|c|c|c|}
\hline 용 & $\therefore \therefore$ & $\therefore \therefore$ & $\therefore \dot{\circ}$ & $\therefore \dot{0}$ & $\therefore \dot{0}$ & $\stackrel{\leftrightarrow}{\circ} \circ 0$ \\
\hline 음 & $\therefore \therefore$ & $\therefore \therefore$ & $\therefore \therefore$ & $\therefore \therefore$ & $\therefore \therefore$ & $\therefore \circ \dot{0}$ \\
\hline$\infty \underset{m}{\infty} \stackrel{\infty}{\stackrel{n}{n}}$ & $\therefore \dot{0}$ & $\therefore \therefore \dot{0}$ & $\therefore \therefore \dot{0}$ & $\therefore \therefore$ & $\therefore \therefore$ & $\therefore \therefore$ \\
\hline$=\bar{m}$ in & $\therefore \circ$ & $\therefore \circ \dot{0}$ & $\therefore \circ \dot{0}$ & $\therefore \therefore \circ$ & $\therefore \dot{0}$ & $\therefore \circ \dot{0}$ \\
\hline 응 & $\therefore \therefore$ & $\therefore \therefore$ & $\therefore \therefore \circ$ & $\therefore \therefore$ & $\therefore \therefore$ & $\therefore \circ$ \\
\hline$\underline{n} \approx n$ & $\therefore \circ$ & $\therefore \therefore \circ$ & $\therefore \circ$ & $\therefore \therefore$ & $\therefore \therefore$ & $\therefore \circ$ \\
\hline \pm 出 & $\dot{0} \dot{0}$ & $\therefore \dot{0}$ & $\therefore \therefore$ & $\therefore \therefore \circ$ & $\therefore \therefore$ & $\therefore \therefore \circ$ \\
\hline$=m n$ & $\therefore \circ$ & $\therefore \therefore$ & $\therefore \circ$ & $\therefore \therefore$ & $\therefore \dot{\circ}$ & $\therefore \therefore$ \\
\hline$\simeq \approx \approx N$ & $\therefore \therefore$ & $\therefore \therefore \circ$ & $\therefore \circ \circ$ & $\therefore \therefore$ & $\therefore \therefore$ & $\therefore \circ$ \\
\hline$\underline{G}=\bar{m}$ 的 & $\therefore \dot{0}$ & $\therefore \dot{0}$ & $\therefore \circ \dot{0}$ & $\therefore \circ:$ & $\therefore \circ \dot{0}$ & $\therefore \therefore$ \\
\hline$\left[\begin{array}{c}0 \\
0\end{array}\right]=$ 요 & $\therefore \dot{0}$ & $\therefore \circ \dot{0}$ & $\therefore \dot{0}$ & $\therefore \dot{0}$ & $\therefore \dot{0}$ & $\therefore \circ$ \\
\hline 힐 & $\therefore \dot{0}$ & $\therefore \dot{0}$ & $\therefore \dot{0}$ & $\therefore \dot{0}$ & $\therefore \circ \dot{0}$ & $\therefore \therefore$ \\
\hline$\infty \stackrel{\infty}{\sim} \stackrel{\infty}{q}$ & $\therefore \circ \dot{0}$ & $\therefore \circ \dot{0}$ & $\therefore \therefore$ & $\therefore \therefore$ & $\therefore \therefore$ & $\therefore \circ 0^{\circ}$ \\
\hline$n=$ & $\therefore \therefore$ & $\therefore \dot{0}$ & $\therefore \therefore$ & $\therefore \therefore$ & $\therefore \circ$ & $\therefore \therefore$ \\
\hline $0 \%$ & $\therefore \therefore$ & $\therefore \dot{0}$ & $\therefore \dot{0}$ & $\therefore \circ$ & $\therefore \circ$ & $\therefore \therefore$ \\
\hline $\ln \curvearrowleft$ & $\therefore \dot{0}$ & $\therefore \circ \dot{0}$ & $\therefore \dot{0}$ & $\therefore \therefore$ & $\therefore \therefore$ & $\therefore \therefore$ \\
\hline 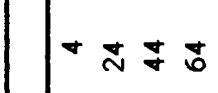 & $\therefore \circ \therefore$ & $\therefore \circ \therefore$ & $\therefore \circ \therefore \circ$ & $\therefore \therefore \therefore$ & $\dot{\circ} \dot{\circ} \dot{\circ}$ & $\therefore \therefore \circ$ \\
\hline 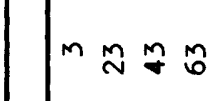 & $\therefore \therefore \therefore$ & $\therefore \circ \therefore$ & $\therefore \circ \therefore$ & $\therefore \therefore \therefore$ & $\therefore \therefore \circ \dot{\circ}$ & 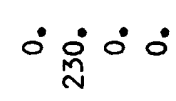 \\
\hline$\sim \sim \mathcal{N}$ & $\therefore \circ \dot{\circ}$ & $\dot{\circ} \dot{0} \dot{\circ}$ & $\therefore \circ \dot{\circ} \dot{0}$ & $\therefore \therefore \circ$ & $\therefore \therefore \circ \dot{0}$ & $\therefore \dot{\mathbb{N}} \circ \dot{\circ}$ \\
\hline $1-\bar{N}=\overline{0}$ & $\therefore \circ: \circ$ & $\therefore \circ \therefore$ & $\therefore \circ \therefore \circ$ & $\therefore \circ \therefore \circ$ & $\therefore \circ \therefore \circ$ & $\therefore \stackrel{\circ}{\circ} \dot{\circ}$ \\
\hline & 0 & $r$ & $\infty$ & $a$ & 은 & $=$ \\
\hline$\frac{0}{20}$ & 产 & $\underset{0}{z}$ & ב⿳亠口冋口𧘇 & בे & $\frac{3}{\alpha}$ & 产 \\
\hline
\end{tabular}




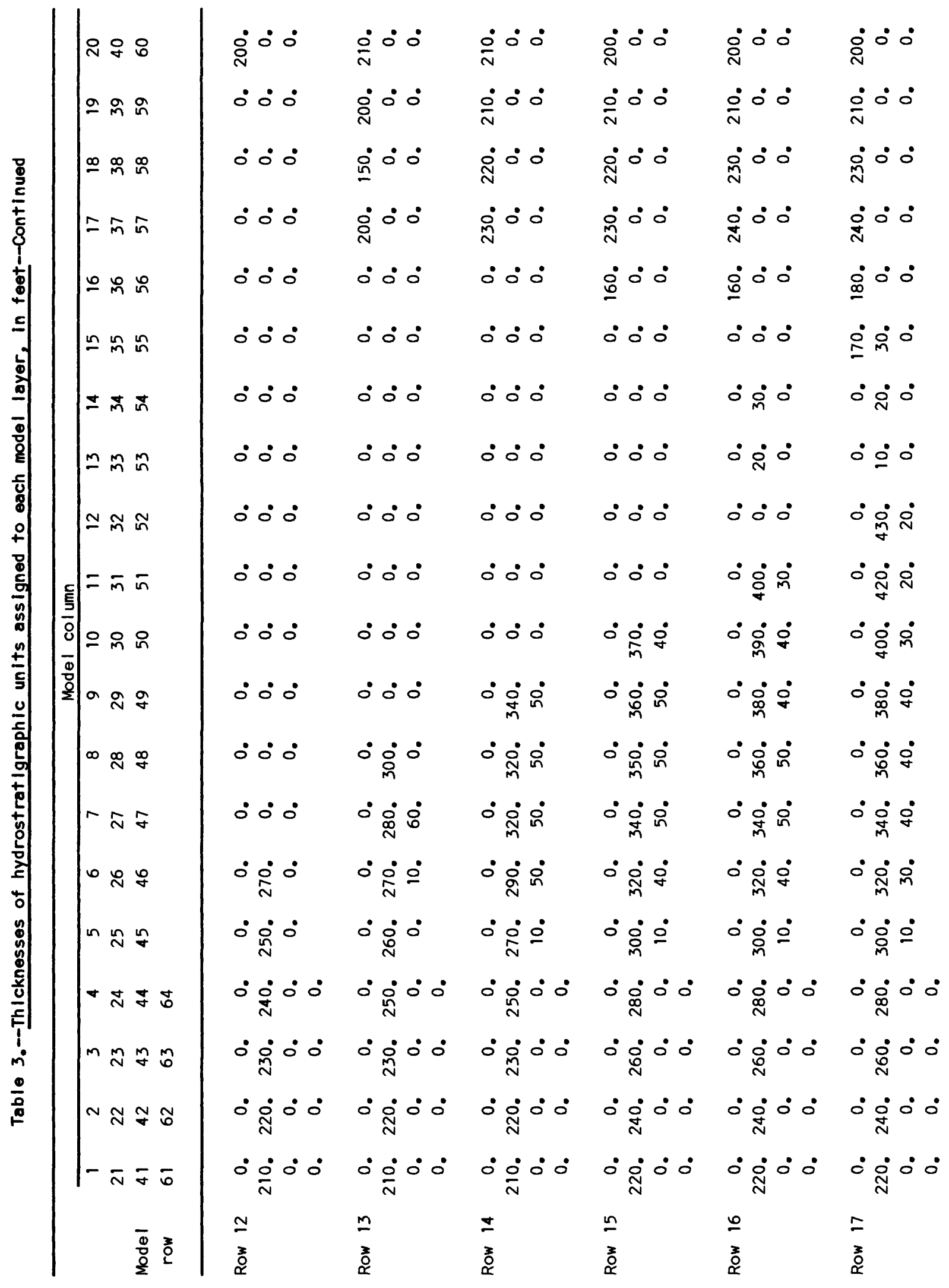




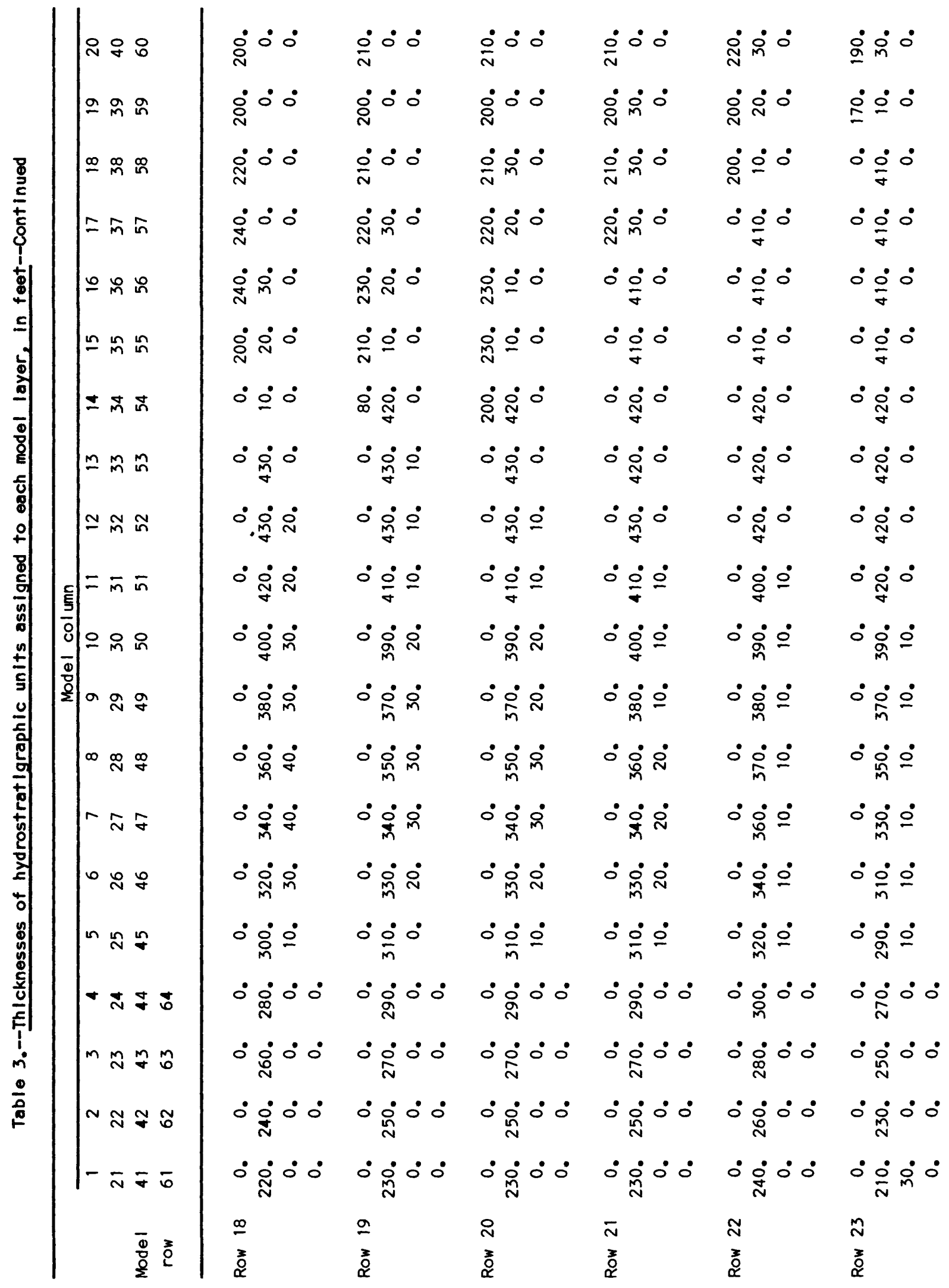




\begin{tabular}{|c|c|c|c|c|c|c|}
\hline 용 & $\dot{\cong} \bigcirc$ & $\therefore \therefore$ & $\therefore \therefore \circ$ & $\therefore \therefore \circ$ & $\therefore \therefore \circ$ & $\therefore \therefore$ \\
\hline g一 & $\therefore \therefore$ & $\therefore \therefore$ & $\therefore \therefore \circ$ & $\therefore \therefore \circ$ & $\therefore \therefore$ & $\therefore \therefore$ \\
\hline$\cong \underset{n}{\infty} \stackrel{\infty}{n}$ & $\therefore \dot{\circ}$ & $\therefore \therefore$ & $\therefore \circ \dot{0}$ & $\therefore \therefore$ & $\therefore \circ$ & $\therefore \therefore$ \\
\hline$=\bar{m}$ in & $\therefore \stackrel{\circ}{\circ}$ & $\therefore \therefore \dot{0}$ & $\therefore \therefore$ & $\therefore \therefore$ & $\therefore \therefore$ & $\therefore \therefore \therefore$ \\
\hline 용 ํํำ & $\therefore \underset{\sigma}{0}$ & $\therefore \frac{0}{8}$ & $\therefore \therefore$ & $\therefore \therefore \therefore$ & $\therefore \therefore$ & $\therefore \therefore 0$ \\
\hline In in in & $\therefore \frac{0}{\square}$ & $\therefore \frac{0}{8} \dot{\circ}$ & $\therefore \therefore$ & $\therefore \therefore \dot{0}$ & $\therefore \therefore \dot{0}$ & $\therefore \therefore \circ$ \\
\hline 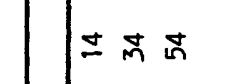 & 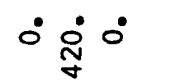 & $\therefore \underset{\text { \ }}{\circ}$ & $\therefore \underset{\sim}{\dot{O}} \dot{0}$ & $\therefore \underset{\sim}{\circ}$ & $\therefore \therefore \circ$ & $\therefore \dot{0}$ \\
\hline$m m i n$ & $\therefore \underset{\sim}{\circ} \circ$ & $\circ \underset{\sim}{\circ}$ & $\therefore \underset{่}{\circ}$ & $\circ \underset{\sim}{\stackrel{\circ}{\circ}}$ & $\therefore \therefore$ & $\therefore \dot{0}$ \\
\hline$\simeq \approx N$ & $\therefore \dot{\sim}$ & $\therefore \underset{\sim}{\dot{0}} \dot{0}$ & $\therefore \underset{\sim}{\circ} \dot{0}$ & $\therefore \stackrel{\text { \} }{\circ}} &{\therefore \underset{\sim}{\circ} \circ} &{\therefore \therefore \circ} \\
{\hline \underline{\underline{E}}=\bar{m} \bar{n}} &{\text { 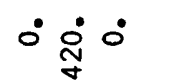 }} &{\dot{\circ} \underset{\sim}{\dot{\gamma}} \dot{0}} &{\therefore \underset{\Im}{\circ} 0^{\circ}} &{\therefore \underset{่}{\circ}} &{\therefore \dot{\sim}} &{\therefore \circ} \\
{\hline\left|\begin{array}{c}\overline{8} \\
\bar{c}\end{array}\right|=0 \text { 응 }} &{\circ \stackrel{\circ}{\circ} \dot{\sigma}} &{\text { 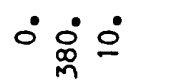 }} &{\text { 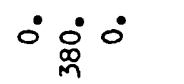 }} &{\therefore \underset{0}{0} \dot{0}} &{\therefore \dot{\circ}} &{\therefore \dot{\circ}} \\
{\hline \text { 일 } \sigma 2 \text { g }} &{\therefore \dot{\circ}} &{\dot{\circ} \dot{0} \stackrel{0}{0}} &{\therefore \stackrel{\circ}{\circ}} &{\therefore \dot{0}} &{\therefore \underset{\text { o }}{\dot{0}}} &{\therefore \underset{m}{\circ} \dot{0}} \\
{\hline \infty \stackrel{\infty}{\sim} \stackrel{\infty}{+}} &{\therefore \dot{0}} &{\therefore \dot{0}} &{\therefore \dot{8}} &{\therefore \stackrel{\circ}{\circ} 0^{\circ}} &{\therefore \stackrel{\circ}{\circ}} &{\therefore \dot{0}} \\
{\hline N \hat{A}} &{\therefore \dot{p}} &{\therefore \underset{\sim}{\stackrel{0}{\infty}}} &{\text { 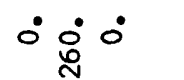 }} &{\therefore \dot{\text { ¿ }}} &{\therefore \frac{0}{m}} &{\therefore \dot{\circ}} \\
{\hline 0 \div 2} &{\dot{\circ} \dot{0} \dot{m}} &{\dot{\circ} \dot{\sim} \dot{0}} &{\therefore \dot{N}} &{\therefore \underset{\Phi}{\dot{0}} \dot{0}} &{\therefore \dot{\circ} \dot{0}} &{\therefore \stackrel{\circ}{\circ}} \\
{\hline \text { in ผ ำ }} &{\therefore \underset{\sim}{0} \dot{0}} &{\therefore \dot{0}} &{\therefore \dot{\Phi}^{\dot{0}}} &{\therefore \dot{q}^{\circ}} &{\text { 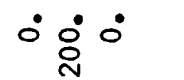 }} &{\therefore \underset{\infty}{\circ} \dot{0}} \\
{\hline \text { 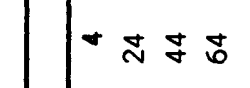 }} &{\dot{\circ} \dot{\circ} \dot{\circ}} &{\therefore \underset{0}{0} \dot{\circ}} &{\therefore \underset{I}{0} \dot{0}} &{\dot{0} \dot{0} \dot{\circ}} &{\dot{\circ} \dot{\circ} \dot{\circ}} &{\therefore \dot{\circ}} \\
{\hline m \cong \mathfrak{N}} &{\dot{\circ} \frac{\dot{N}}{\infty} \dot{m}} &{\therefore \underset{\underline{m}}{\dot{0}} \dot{0}} &{\dot{\circ} \therefore \dot{0}} &{\dot{\circ} \dot{0} \dot{\circ} \dot{0}} &{\therefore \dot{m}} &{\therefore \circ \dot{0}} \\
{\hline \sim \mathcal{N} \text { พ }} &{\dot{\circ} \dot{\infty} \dot{\infty} \dot{\circ}} &{\therefore \dot{\circ} \therefore} &{\therefore \text { in } \dot{\circ}} &{\therefore \circ \dot{0} \dot{0}} &{\therefore \circ \therefore \circ} &{\therefore \circ \circ \circ} \\
{\hline-\bar{N} \bar{\sigma}} &{\therefore \dot{0} \therefore \dot{0}} &{\dot{\circ} \dot{0} \dot{0} \dot{\circ}} &{\therefore \therefore \circ} &{\therefore \therefore \therefore} &{\text { 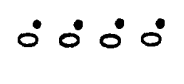 }} &{\circ 0^{\circ} 0^{\circ}} \\
{\hline} &{\text { N }} &{N} &{\stackrel{2}{\sim}} &{\bar{N}} &{\stackrel{\infty}{\sim}} &{\text { ลิ }} \\
{\hline \frac{0}{2}} &{\underset{\alpha}{2}} &{\frac{7}{a}} &{{ }_{\alpha}^{7}} &{\frac{\pi}{0}} &{\text { 产 }} &{\frac{7}{2}} \\
$\hline
\end{tabular}




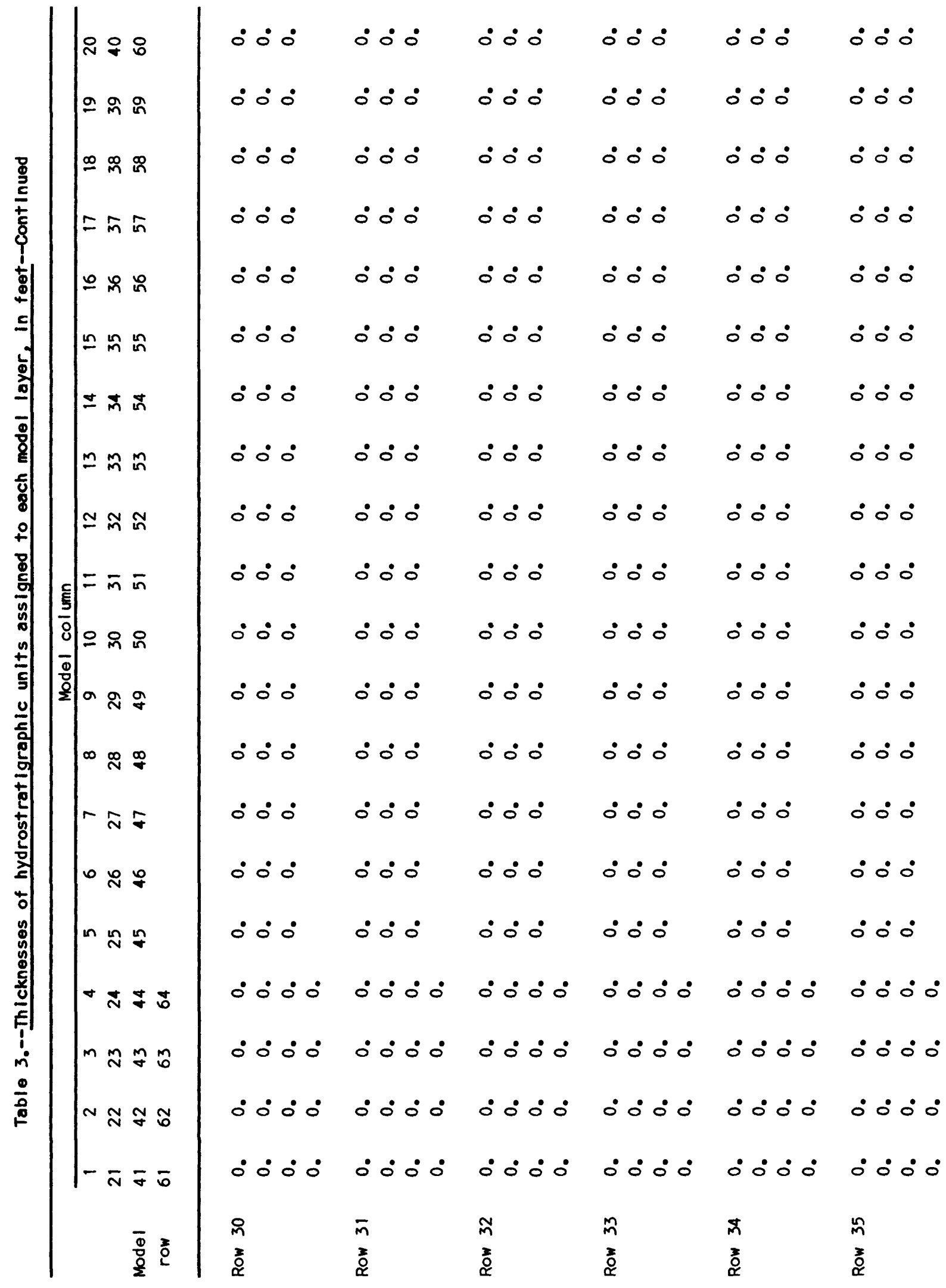




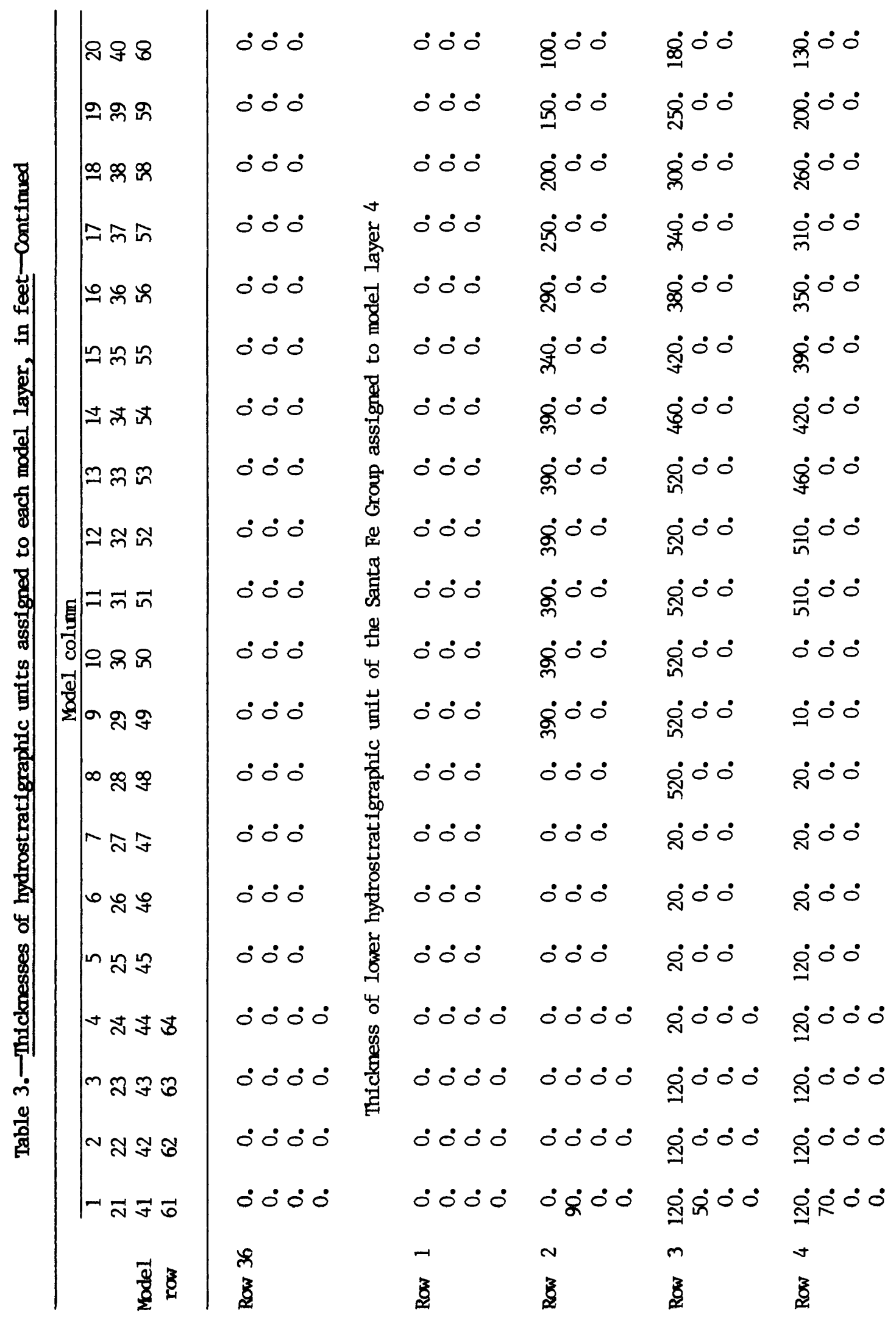




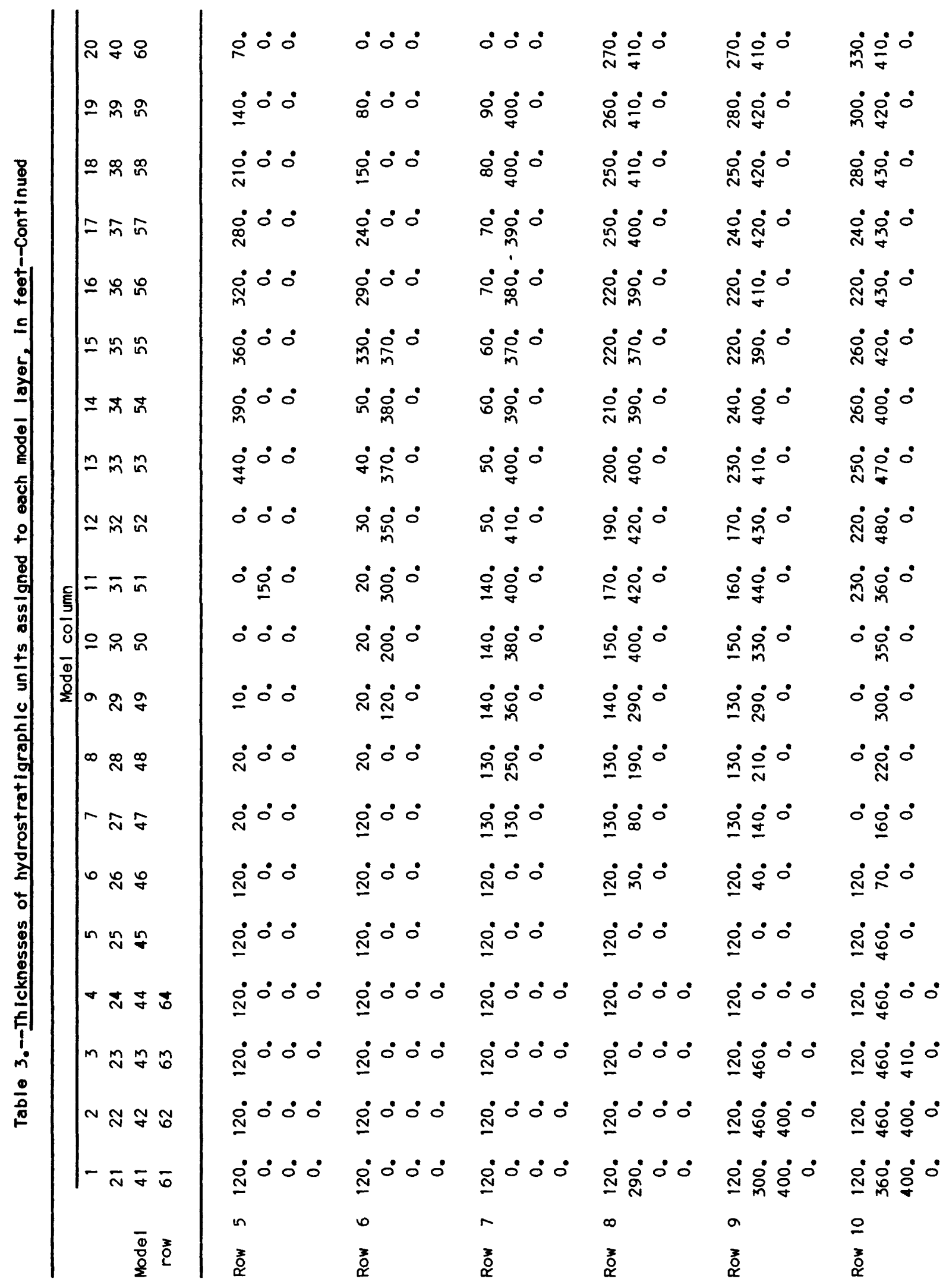




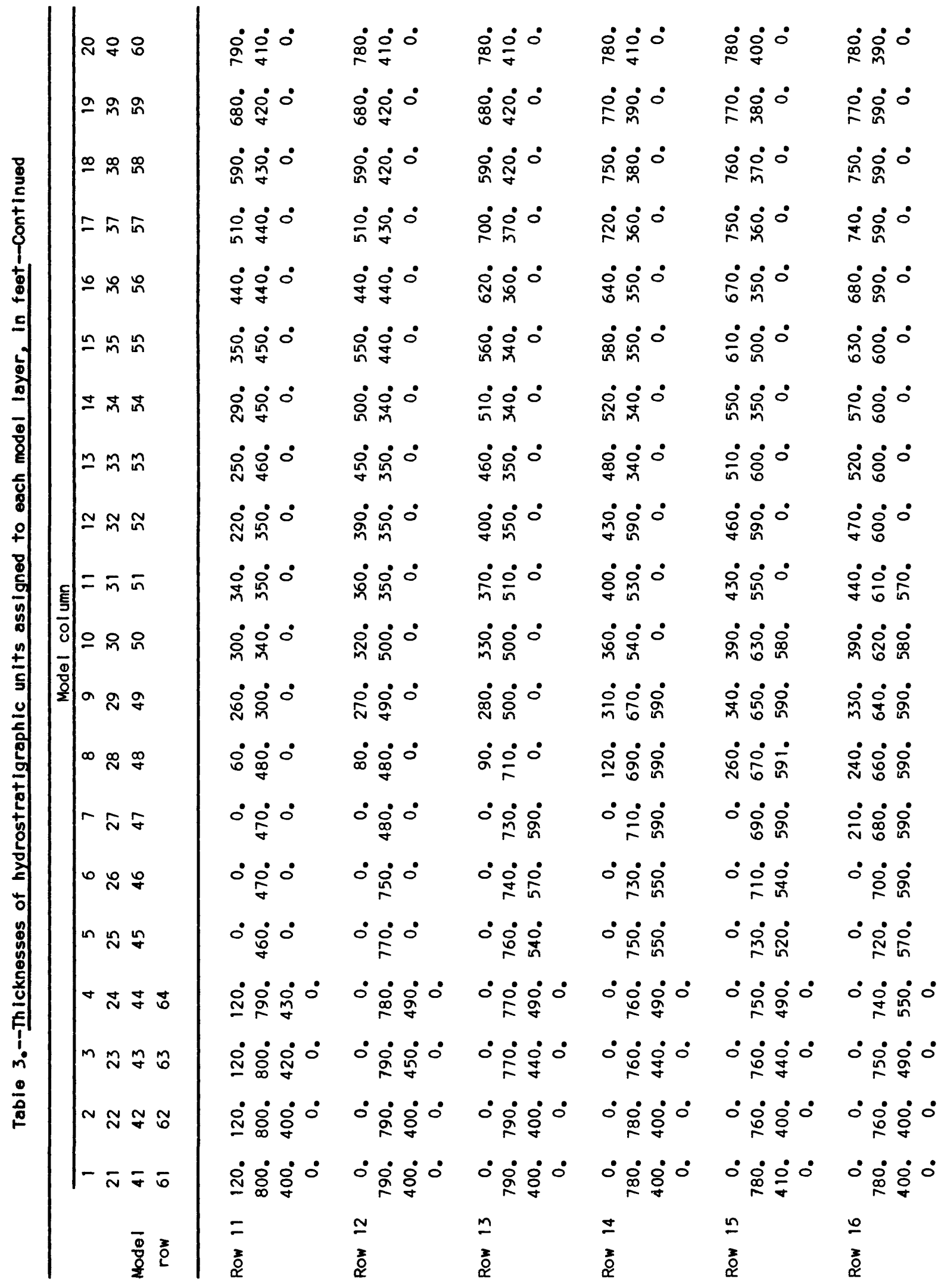




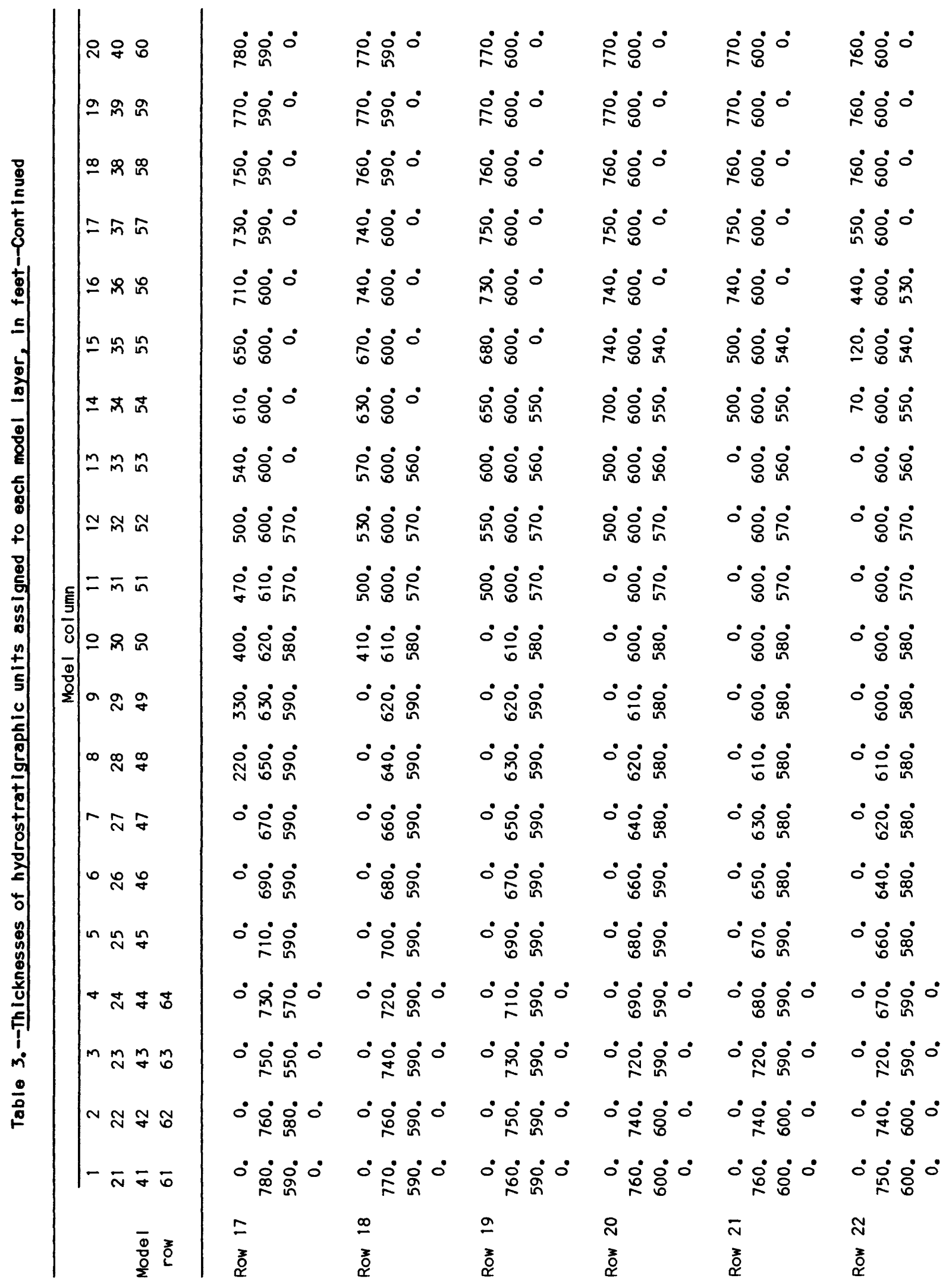




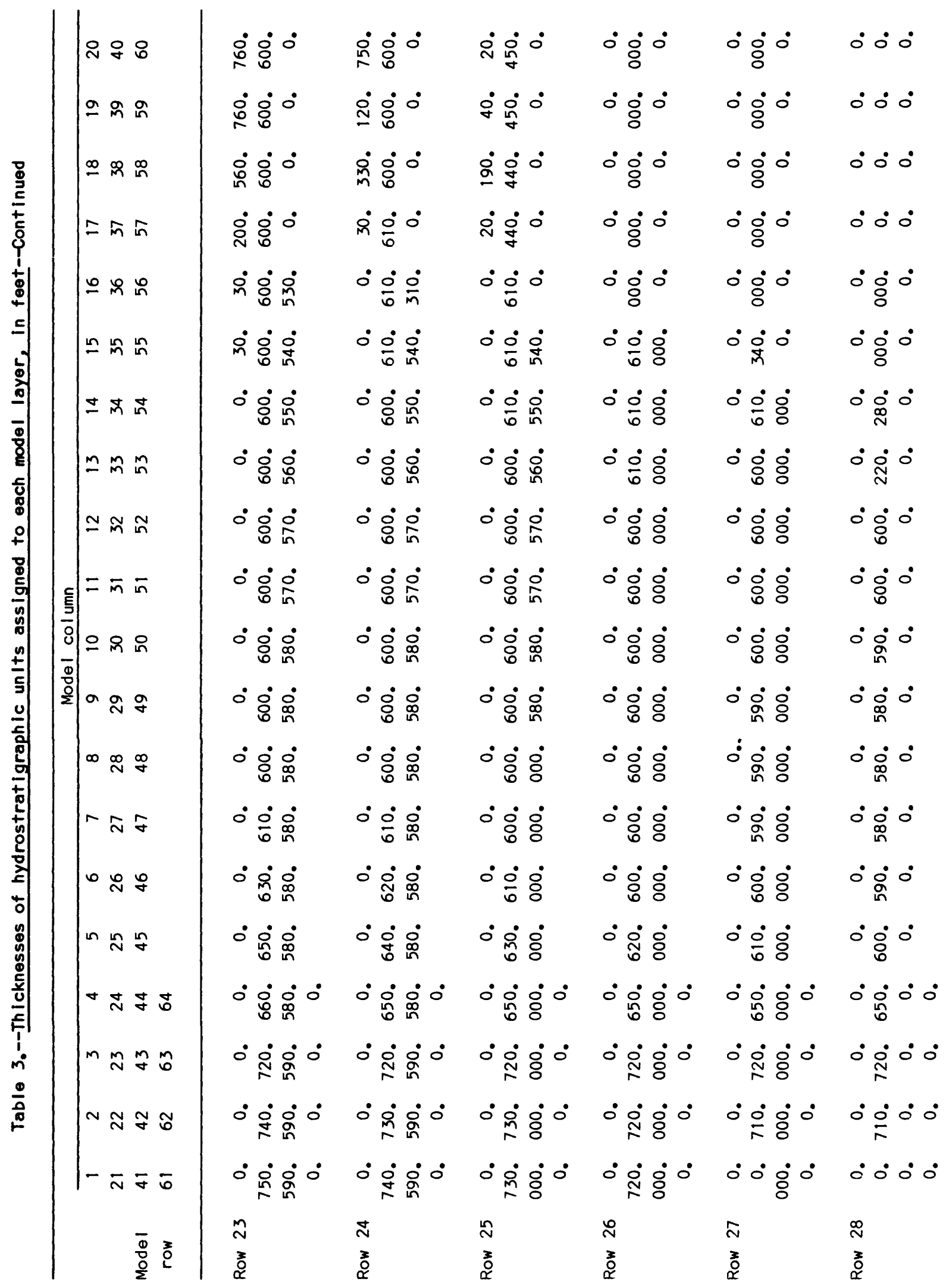




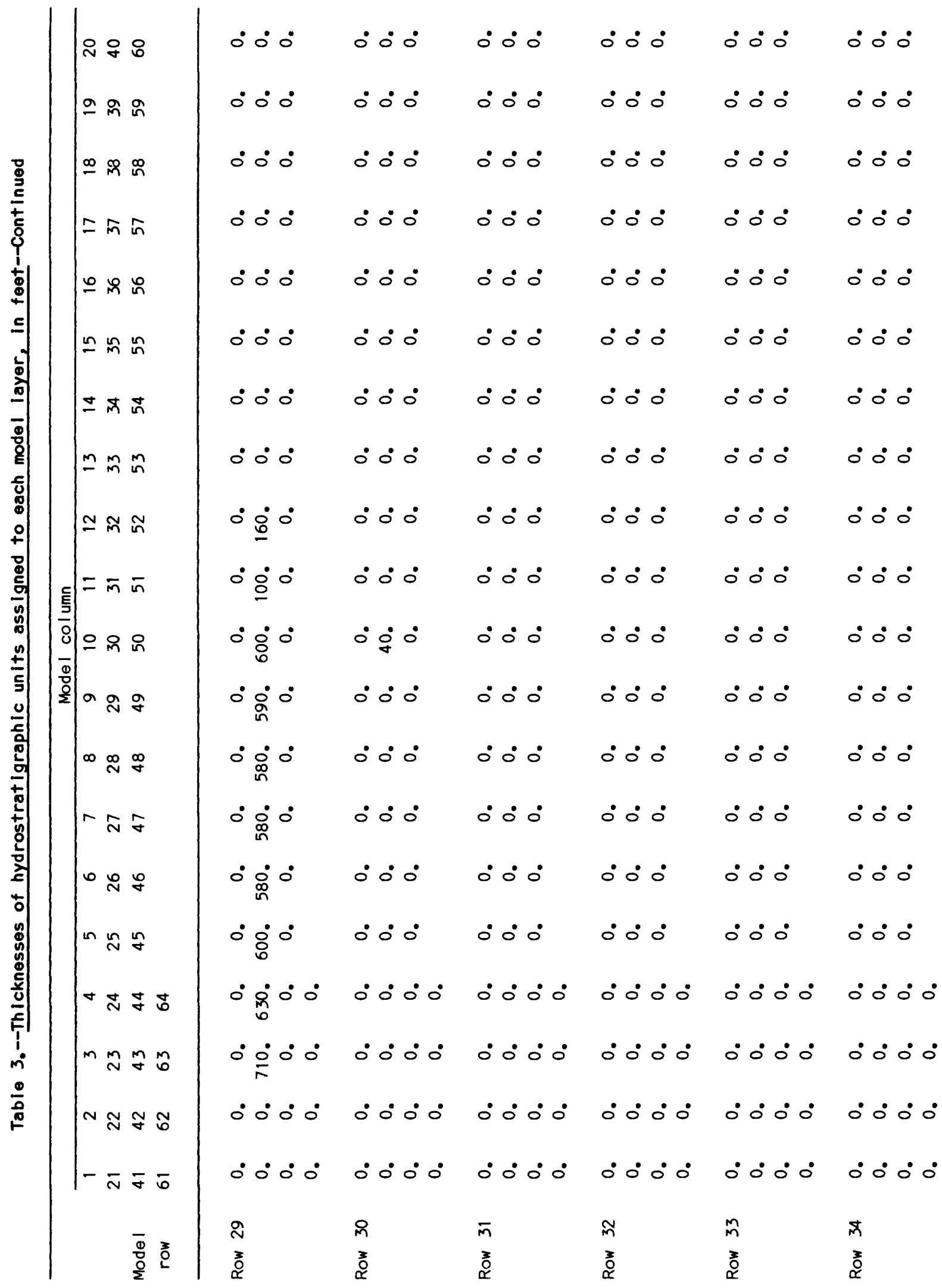




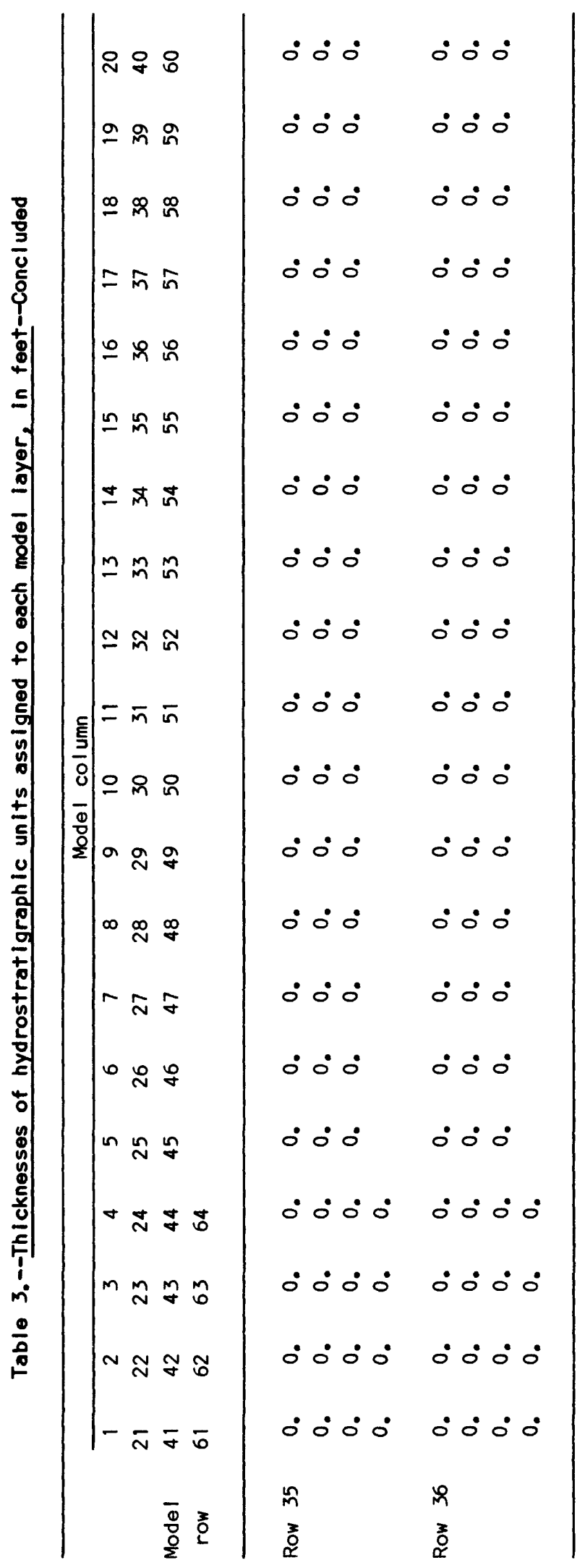


Table 4.-- Specified inflow to river reaches by stress period

\begin{tabular}{|c|c|c|c|}
\hline \multirow[b]{2}{*}{$\begin{array}{l}\text { Stress } \\
\text { period }\end{array}$} & \multicolumn{3}{|c|}{ Specified inflow, in cubic feet per second } \\
\hline & $\begin{array}{l}\text { Reach } 1 \text {, } \\
\text { Rio } \\
\text { Grande at } \\
\text { Leasburg } \\
\text { diversion }\end{array}$ & $\begin{array}{l}\text { Reach 5, } \\
\text { Rio } \\
\text { Grande at } \\
\text { Las Cruces } \\
\text { wastewater } \\
\text { outfall }\end{array}$ & $\begin{array}{l}\text { Reach } 45, \\
\text { drain at } \\
\text { Anthony } \\
\text { wastewater } \\
\text { outfall }\end{array}$ \\
\hline 1 & $1,082.000$ & 0.151 & 0.000 \\
\hline 2 & $1,003.000$ & 0.170 & 0.000 \\
\hline 3 & 515.000 & 0.260 & 0.000 \\
\hline 4 & 655.000 & 0.490 & 0.000 \\
\hline 5 & 375.000 & 1.330 & 0.000 \\
\hline 6 & 303.000 & 2.430 & 0.000 \\
\hline 7 & 200.000 & 3.710 & 0.000 \\
\hline 8 & 452.000 & 4.850 & 0.000 \\
\hline 9 & 274.000 & 4.790 & 0.000 \\
\hline 10 & 287.000 & 5.370 & 0.000 \\
\hline 11 & 111.000 & 6.160 & 0.000 \\
\hline 12 & 320.000 & 5.970 & 0.000 \\
\hline 13 & 317.000 & 5.370 & 0.000 \\
\hline 14 & 331.000 & 6.070 & 0.000 \\
\hline 15 & 189.000 & 6.420 & 0.000 \\
\hline 16 & 373.000 & 6.760 & 0.000 \\
\hline 17 & 346.370 & 7.067 & 1.286 \\
\hline 18 & 252.200 & 7.072 & 1.685 \\
\hline 19 & 416.660 & 7.343 & 1.267 \\
\hline 20 & 406.200 & 7.851 & 1.018 \\
\hline 21 & 365.280 & 9.145 & 0.894 \\
\hline 22 & 456.310 & 9.181 & 0.968 \\
\hline
\end{tabular}


Table 5.- Schedule of nonagricultural ground-water withdrawal specified in the model

[Units are cubic feet per second]

\begin{tabular}{|c|c|c|c|c|c|c|c|c|c|c|c|c|}
\hline & $\mathrm{C}$ & & & & & & & & & & & \\
\hline $\mathrm{L}$ & 0 & & & & & & & & & & & \\
\hline a & 1 & & & & & & & & & & & \\
\hline y $R$ & $\mathrm{u}$ & 1915 & 1920 & 1927 & 1941 & 1948 & 1951 & 1954 & 1958 & & 1962 & \\
\hline $\begin{array}{ll}e & o\end{array}$ & m & - & - & - & - & - & - & - & - & & - & \\
\hline$r \quad w$ & $\mathrm{n}$ & 1919 & 1926 & 1940 & 1947 & 1950 & 1953 & 1957 & 1960 & 1961 & 1963 & 1964 \\
\hline 113 & 8 & 0 & 0 & 0 & 0 & 0 & 0 & 0 & 0 & 0 & 0 & 0 \\
\hline 114 & 7 & 0 & 0 & 0 & 0 & 0 & 0 & 0 & 0 & 0 & 0 & 0 \\
\hline 115 & 7 & 0 & 0 & 0 & 0 & 0 & 0 & 0 & 0 & 0 & 0 & 0 \\
\hline 116 & 4 & 0 & 0 & 0 & 0 & 0 & 0 & 0 & 0 & 0 & 0 & 0 \\
\hline 116 & 8 & 0 & 0 & 0 & 0 & 0 & 0 & 0 & 0 & 0 & 0 & 0 \\
\hline 118 & 4 & 0 & 0 & 0 & 0 & 0 & -1.117 & -2.360 & -2.820 & -2.650 & -2.627 & -2.407 \\
\hline 119 & 3 & 0 & 0 & 0 & 0 & 0 & 0 & 0 & 0 & 0 & 0 & 0 \\
\hline 119 & 4 & 0 & 0 & 0 & 0 & 0 & -1.000 & -2.102 & -1.161 & -1.081 & -1.071 & -0.981 \\
\hline 120 & 2 & 0 & 0 & 0 & 0 & -0.007 & -0.021 & -0.021 & -0.021 & -0.021 & -0.021 & -0.021 \\
\hline 122 & 11 & 0 & 0 & 0 & 0 & 0 & -0.633 & -1.077 & -0.080 & -0.970 & -0.913 & -0.914 \\
\hline 122 & 12 & 0 & 0 & 0 & 0 & 0 & 0 & 0 & 0 & 0 & 0 & 0 \\
\hline 122 & 13 & 0 & 0 & 0 & 0 & 0 & -0.633 & -2.497 & -0.791 & -0.952 & -2.085 & -3.767 \\
\hline 123 & 9 & 0 & 0 & 0 & 0 & 0 & 0 & 0 & 0 & 0 & 0 & 0 \\
\hline 123 & 11 & 0 & 0 & 0 & 0 & 0 & 0 & -0.703 & -0.605 & -0.974 & -0.958 & -0.945 \\
\hline 1231 & 12 & 0 & 0 & 0 & 0 & 0 & -1.267 & -2.550 & -1.782 & -1.316 & -2.944 & -2.651 \\
\hline 1231 & 13 & 0 & 0 & 0 & 0 & 0 & -0.633 & -1.613 & -0.504 & -0.202 & -1.058 & -1.062 \\
\hline 1234 & 42 & 0 & 0 & 0 & 0 & 0 & 0 & 0 & 0 & 0.006 & 0.014 & 0.019 \\
\hline 1235 & 51 & 0 & 0 & 0 & 0 & 0 & 0 & 0 & 0 & 0 & 0 & 0.009 \\
\hline 1235 & 53 & 0 & 0 & 0 & 0 & 0 & 0 & 0 & 0 & 0 & 0 & 0 \\
\hline 1241 & 11 & 0 & 0 & 0 & 0 & 0 & 0 & 0 & 0 & 0 & 0 & 0 \\
\hline 1241 & 13 & 0 & 0 & 0 & 0 & 0 & -0.633 & -0.860 & -0.638 & -0.312 & -0.441 & -0.271 \\
\hline 1241 & 14 & 0 & 0 & 0 & 0 & 0 & 0 & 0 & 0 & 0 & 0 & 0 \\
\hline 1241 & 16 & 0 & 0 & 0 & 0 & 0 & 0 & 0 & 0 & 0 & 0 & 0 \\
\hline 1244 & 47 & 0 & -0.046 & -0.043 & 0 & 0 & 0 & 0 & 0 & 0 & 0 & 0 \\
\hline 125 & 7 & 0 & 0 & 0 & 0 & 0 & 0 & 0 & 0 & 0 & 0 & 0 \\
\hline 1253 & 39 & 0 & 0 & 0 & 0 & 0 & 0 & 0 & 0 & 0 & 0 & 0 \\
\hline 1254 & 42 & 0 & 0 & 0 & 0 & 0 & 0 & 0 & 0 & 0 & 0 & 0 \\
\hline 1261 & 13 & 0 & 0 & 0 & 0 & 0 & 0 & 0 & 0 & 0 & 0 & 0 \\
\hline 1263 & 31 & 0 & 0 & 0 & 0 & 0 & 0 & 0 & 0 & 0 & 0 & 0 \\
\hline 1264 & 42 & 0 & 0 & 0 & 0 & 0 & 0 & 0 & 0 & 0 & 0 & 0 \\
\hline 1265 & 52 & 0 & 0 & 0 & 0 & 0 & 0 & 0 & 0 & 0 & 0 & 0 \\
\hline 1265 & 54 & 0 & 0 & 0 & 0 & 0 & 0 & 0 & 0 & 0 & 0 & 0 \\
\hline 1265 & 55 & 0 & 0 & 0 & 0 & 0 & 0 & 0 & 0 & 0 & 0 & 0 \\
\hline 1273 & 39 & 0 & 0 & 0 & 0 & 0 & 0 & 0 & 0 & 0 & 0 & 0 \\
\hline 1281 & 11 & 0 & 0 & 0 & 0 & 0 & 0 & 0 & 0 & 0 & 0 & 0 \\
\hline
\end{tabular}




\begin{tabular}{|c|c|c|c|c|c|c|c|c|c|c|c|c|c|}
\hline & & C & & & & & & & & & & & \\
\hline L & & 0 & & & & & & & & & & & \\
\hline$a$ & & 1 & & & & & & & & & & & \\
\hline$y$ & $\mathrm{R}$ & $\mathbf{u}$ & 1915 & 1920 & 1927 & 1941 & 1948 & 1951 & 1954 & 1958 & & 1962 & \\
\hline e & 0 & m & - & - & - & - & - & - & - & - & & - & \\
\hline$r$ & $\mathbf{w}$ & $\mathrm{n}$ & 1919 & 1926 & 1940 & 1947 & 1950 & 1953 & 1957 & 1960 & 1961 & 1963 & 1964 \\
\hline
\end{tabular}

\begin{tabular}{|c|c|c|c|c|c|c|c|c|c|c|c|}
\hline 2843 & 0 & 0 & 0 & 0 & 0 & -0.372 & -1.137 & -1.053 & -0.935 & -0.824 & -0.820 \\
\hline 2846 & -0.302 & -0.302 & -0.479 & -1.285 & -2.968 & -3.041 & -2.578 & -2.411 & -2.175 & -1.953 & -1.944 \\
\hline & 0 & 0 & 0 & 0 & 0 & -0.372 & -1.137 & -1.053 & -0.935 & -0.824 & -0.820 \\
\hline 7 & 0 & 0 & 0 & 0 & 0 & 0 & 0 & 0 & 0 & 0 & 0 \\
\hline 8 & 0 & 0 & 0 & 0 & 0 & 0 & 0 & 0 & 0 & 0 & 0 \\
\hline
\end{tabular}

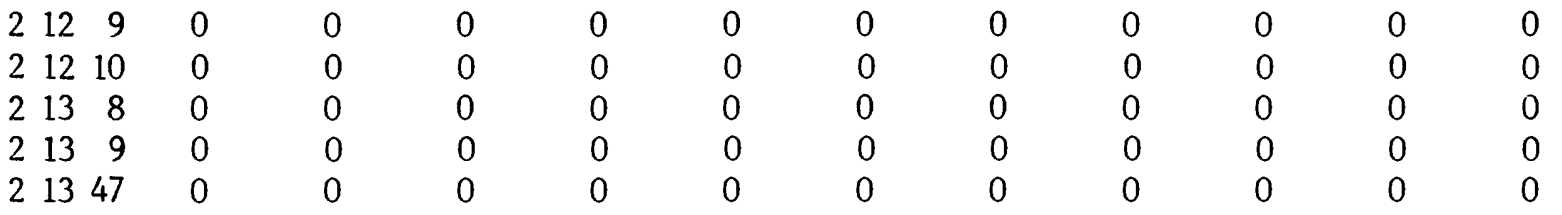

\begin{tabular}{|c|c|c|c|c|c|c|c|c|c|c|c|c|}
\hline 214 & 7 & 0 & 0 & 0 & 0 & 0 & 0 & 0 & 0 & 0 & 0 & 0 \\
\hline 214 & 8 & 0 & 0 & 0 & 0 & 0 & 0 & 0 & 0 & 0 & 0 & 0 \\
\hline 215 & 6 & 0 & 0 & 0 & 0 & 0 & 0 & 0 & 0 & 0 & 0 & 0 \\
\hline 15 & 7 & 0 & 0 & 0 & 0 & 0 & 0 & 0 & 0 & 0 & 0 & 0 \\
\hline 216 & 4 & 0 & 0 & 0 & 0 & 0 & 0 & 0 & 0 & 0 & 0 & 0 \\
\hline 16 & 7 & 0 & 0 & 0 & 0 & 0 & 0 & 0 & 0 & 0 & 0 & 0 \\
\hline 217 & 7 & 0 & 0 & 0 & 0 & 0 & 0 & 0 & 0 & 0 & 0 & 0 \\
\hline 219 & 11 & 0 & 0 & 0 & 0 & 0 & 0 & 0 & 0 & 0 & 0 & 0 \\
\hline 219 & 16 & -0.047 & -0.066 & -0.081 & -0.062 & -0.053 & -0.052 & -0.052 & -0.052 & -0.052 & -0.052 & -0.052 \\
\hline 19 & 49 & 0 & 0 & -0.002 & -0.027 & -0.029 & -0.029 & -0.029 & -0.029 & -0.029 & -0.029 & -0.029 \\
\hline 2 & 13 & 0 & 0 & 0 & 0 & 0 & 0 & 0 & 0 & 0 & 0 & -0.554 \\
\hline 221 & 23 & 0 & -0.038 & -0.053 & -0.033 & -0.030 & -0.030 & -0.030 & -0.030 & -0.030 & -0.030 & -0.030 \\
\hline 222 & 13 & 0 & 0 & 0 & 0 & 0 & 0 & 0 & 0 & 0 & 0 & 0 \\
\hline 222 & 31 & 0 & 0 & -0.003 & -0.052 & -0.058 & -0.059 & -0.059 & -0.059 & -0.059 & -0.059 & -0.059 \\
\hline 222 & 43 & -0.072 & -0.094 & -0.129 & -0.107 & -0.119 & -0.122 & -0.122 & -0.122 & -0.122 & -0.122 & -0.122 \\
\hline 223 & 9 & 0 & 0 & 0 & 0 & 0 & 0 & 0 & 0 & 0 & 0 & 0 \\
\hline 223 & 10 & 0 & 0 & 0 & 0 & 0 & 0 & 0 & 0 & 0 & 0 & 0 \\
\hline 223 & 12 & 0 & 0 & 0 & 0 & 0 & 0 & 0 & 0 & 0 & 0 & -2.025 \\
\hline 223 & 28 & -0.039 & -0.054 & -0.061 & -0.054 & -0.059 & -0.059 & -0.059 & -0.059 & -0.059 & -0.059 & -0.059 \\
\hline 2 & 42 & 0 & 0 & 0 & 0 & 0 & 0 & 0 & 0 & -0.013 & -0.030 & -0.039 \\
\hline & 47 & 0 & 0 & 0 & 0 & 0 & 0 & 0 & 0 & 0 & 0 & 0 \\
\hline & 50 & 0 & 0 & 0 & 0 & 0 & 0 & 0 & 0 & 0 & 0 & 0 \\
\hline & 51 & 0 & 0 & 0 & 0 & 0 & 0 & 0 & 0 & 0 & 0 & -0.018 \\
\hline & 52 & 0 & 0 & -0.023 & -0.029 & -0.029 & -0.029 & -0.029 & -0.029 & -0.029 & -0.029 & -0.029 \\
\hline 223 & 53 & 0 & 0 & 0 & 0 & 0 & 0 & 0 & 0 & 0 & 0 & 0 \\
\hline
\end{tabular}


Table 5. - Schedule of nonagricultural ground-water withdrawal specifled in the model-Contimued

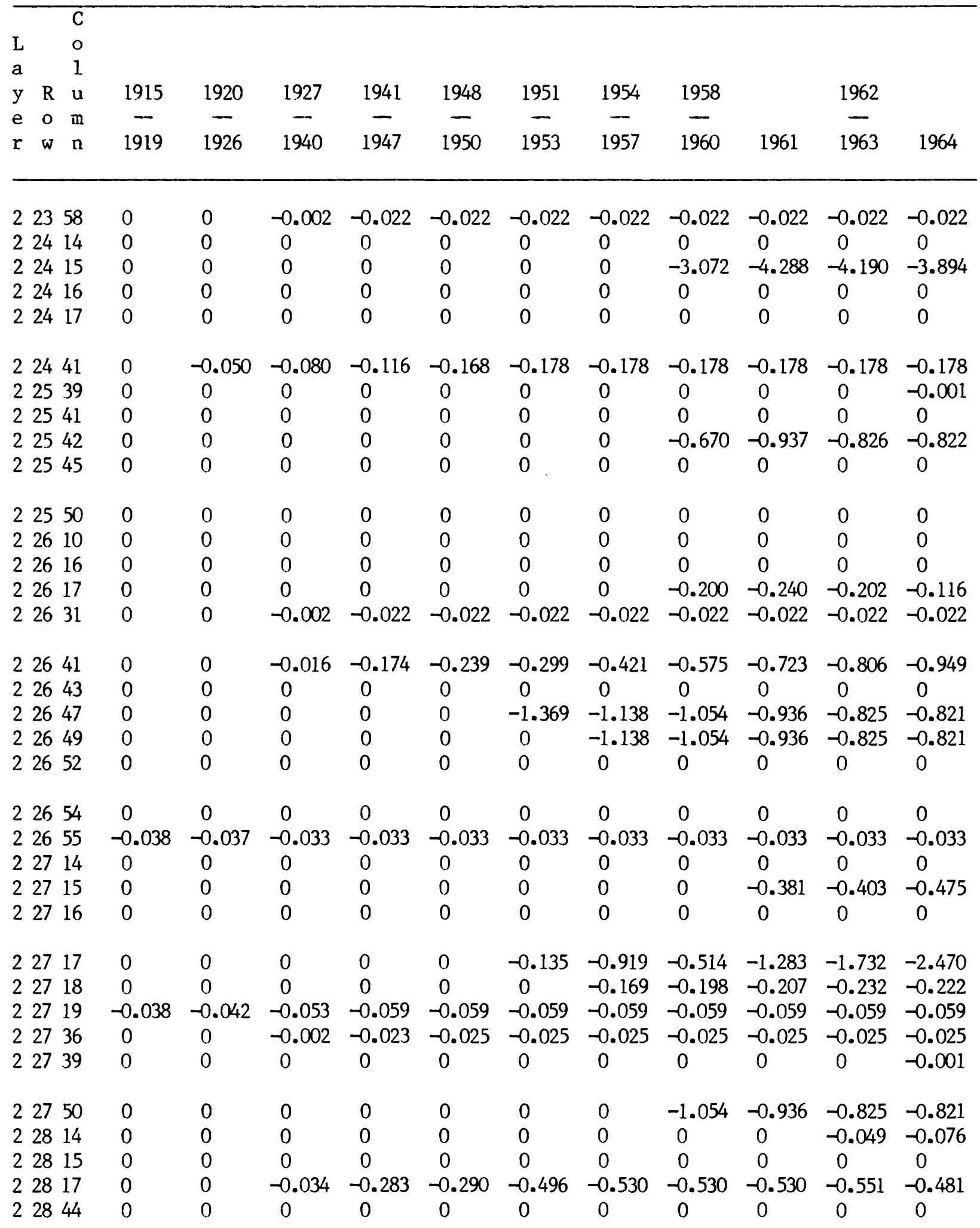


Table 5. - Schedule of nonagricultural ground-water withdrawal specified in the model-Continued

\begin{tabular}{|c|c|c|c|c|c|c|c|c|c|c|c|c|}
\hline & C & & & & & & & & & & & \\
\hline $\mathrm{L}$ & 0 & & & & & & & & & & & \\
\hline a & 1 & & & & & & & & & & & \\
\hline y $R$ & $\mathrm{u}$ & 1915 & 1920 & 1927 & 1941 & 1948 & 1951 & 1954 & 1958 & & 1962 & \\
\hline e 0 & $\mathrm{~m}$ & - & - & - & - & - & - & - & - & & - & \\
\hline$r \quad w$ & $\mathrm{n}$ & 1919 & 1926 & 1940 & 1947 & 1950 & 1953 & 1957 & 1960 & 1961 & 1963 & 1964 \\
\hline 228 & & 0 & 0 & 0 & 0 & 0 & 0 & 0 & 0 & 0 & 0 & 0 \\
\hline 228 & & 0 & 0 & 0 & 0 & 0 & 0 & 0 & -0.300 & -0.936 & -0.825 & -0.821 \\
\hline 228 & & 0 & 0 & 0 & 0 & 0 & 0 & 0 & 0 & 0 & 0 & 0 \\
\hline 228 & & 0 & 0 & 0 & 0 & 0 & 0 & 0 & 0 & 0 & 0 & 0 \\
\hline 228 & 50 & 0 & 0 & 0 & 0 & 0 & 0 & 0 & 0 & 0 & 0 & -0.821 \\
\hline 229 & 23 & 0 & -0.033 & -0.042 & -0.021 & -0.021 & -0.021 & -0.021 & -0.021 & -0.021 & -0.021 & -0.021 \\
\hline 229 & 43 & 0 & 0 & 0 & 0 & 0 & 0 & -0.581 & -1.054 & -0.936 & -0.825 & -0.821 \\
\hline 229 & 44 & 0 & 0 & 0 & 0 & 0 & 0 & 0 & -0.300 & -0.936 & -0.825 & -0.821 \\
\hline 229 & 45 & 0 & 0 & 0 & 0 & 0 & 0 & 0 & 0 & 0 & -0.826 & -0.822 \\
\hline 229 & 46 & 0 & 0 & 0 & 0 & 0 & 0 & 0 & 0 & 0 & -0.826 & -1.643 \\
\hline 230 & 44 & 0 & 0 & 0 & 0 & 0 & 0 & 0 & 0 & 0 & 0 & 0 \\
\hline 324 & 15 & 0 & 0 & 0 & 0 & 0 & 0 & -0.940 & -6.794 & -6.693 & -9.118 & -7.805 \\
\hline 324 & 16 & 0 & 0 & 0 & 0 & 0 & 0 & -0.147 & -3.149 & -2.184 & -2.321 & -0.597 \\
\hline 324 & 17 & 0 & 0 & 0 & 0 & 0 & 0 & 0 & 0 & -0.334 & -2.040 & -3.746 \\
\hline 325 & 16 & 0 & 0 & 0 & 0 & 0 & 0 & 0 & -1.455 & -3.175 & -2.249 & -2.396 \\
\hline 326 & 14 & 0 & 0 & 0 & 0 & 0 & 0 & 0 & 0 & 0 & 0 & 0 \\
\hline 326 & 16 & 0 & 0 & 0 & 0 & 0 & 0 & 0 & 0 & 0 & 0 & 0 \\
\hline 326 & 17 & 0 & 0 & 0 & 0 & 0 & 0 & 0 & 0 & 0 & 0 & 0 \\
\hline 327 & 17 & 0 & 0 & 0 & 0 & 0 & 0 & 0 & 0 & 0 & 0 & 0 \\
\hline 327 & 18 & 0 & 0 & 0 & 0 & 0 & 0 & 0 & 0 & 0 & 0 & 0 \\
\hline Tota & als & -0.54 & -0.76 & -1.14 & -2.40 & -4.23 & -12.76 & -25.36 & -35.63 & -39.86 & -47.80 & -52.21 \\
\hline
\end{tabular}




\begin{tabular}{|c|c|c|c|c|c|c|c|c|c|c|c|c|}
\hline L & $\begin{array}{l}\mathrm{C} \\
\mathrm{O}\end{array}$ & & & & & & & & & & & \\
\hline $\begin{array}{ll}a & \\
y & R\end{array}$ & 1 & & & & & & & & & & & \\
\hline $\begin{array}{ll}\mathrm{y} & \mathrm{R} \\
\mathrm{e} & \mathrm{o}\end{array}$ & $\begin{array}{l}\mathrm{u} \\
\mathrm{m}\end{array}$ & 1965 & $\begin{array}{c}1967 \\
-\end{array}$ & $\begin{array}{c}1969 \\
-\end{array}$ & & $\begin{array}{c}19 / 3 \\
-\end{array}$ & & 19/1 & $\begin{array}{c}19 / 9 \\
-\end{array}$ & $\begin{array}{l}1981 \\
-\end{array}$ & 1983 & \\
\hline$r \quad w$ & $\mathrm{n}$ & 1966 & 1968 & 1971 & 1972 & 1975 & 1976 & 1978 & 1980 & 1982 & 1984 & 1985 \\
\hline 113 & 8 & 0 & 0 & 0 & 0 & 0 & -0.387 & -0.664 & -0.226 & 0 & 0 & 0 \\
\hline 114 & 7 & 0 & 0 & 0 & 0 & 0 & -0.387 & -0.420 & -0.579 & -0.665 & -0.462 & -0.458 \\
\hline 115 & 7 & 0 & 0 & 0 & 0 & 0 & 0.765 & 1.285 & 1.285 & 1.279 & 1.676 & 1.715 \\
\hline 116 & 4 & 0 & 0 & 0 & 0 & 0 & -2.817 & -2.305 & -2.586 & -2.578 & -1.405 & -1.708 \\
\hline 116 & 8 & 0 & 0 & 0 & 0 & 0 & 0 & -0.489 & -0.417 & 0 & 0 & 0 \\
\hline 118 & 4 & -2.236 & -2.307 & -2.357 & -3.238 & -3.336 & -0.377 & -0.308 & -0.346 & -0.704 & -0.073 & -0.043 \\
\hline 119 & 3 & 0 & 0 & 0 & 0 & 0 & -0.970 & -0.794 & -0.891 & -0.553 & -0.255 & -0.460 \\
\hline 119 & 4 & -0.911 & -0.940 & -0.961 & -1.321 & -1.361 & 0 & 0 & 0 & 0 & 0 & 0 \\
\hline 120 & 2 & -0.021 & -0.021 & -0.021 & -0.021 & -0.021 & -0.021 & -0.021 & -0.021 & -0.021 & -0.021 & -0.021 \\
\hline 122 & 11 & -0.422 & -0.694 & -0.650 & -0.662 & -0.493 & -0.136 & -0.432 & -0.038 & -0.001 & 0 & 0 \\
\hline 122 & 12 & 0 & 0 & 0 & 0 & 0 & -0.056 & -0.056 & -0.056 & -0.056 & -0.056 & -0.056 \\
\hline 122 & 13 & -2.204 & -2.881 & -2.071 & -3.171 & -2.000 & -0.340 & -1.696 & -0.210 & 0 & -0.015 & 0 \\
\hline 123 & 9 & 0 & 0 & 0 & 0 & 0 & 0 & -0.014 & -0.028 & -0.028 & -0.028 & -0.028 \\
\hline 123 & 11 & -0.443 & -1.485 & -1.446 & -1.946 & -1.247 & -0.256 & -1.099 & -0.275 & -0.001 & -0.685 & -1.366 \\
\hline 123 & 12 & -1.597 & -2.149 & -1.715 & -2.170 & -1.569 & -0.101 & -0.461 & -0.040 & 0 & -0.005 & 0 \\
\hline 123 & 13 & -1.040 & -1.646 & -1.085 & -1.372 & -0.844 & -0.386 & -1.924 & -0.405 & -0.021 & -0.020 & 0 \\
\hline 123 & 42 & 0.033 & 0.039 & 0.037 & 0.041 & 0.060 & 0.029 & 0.076 & 0.092 & 0.101 & 0.124 & 0.116 \\
\hline 123 & 51 & 0.015 & 0.018 & 0.017 & 0.020 & 0.032 & 0.053 & 0.067 & 0.073 & 0.076 & 0.079 & 0.078 \\
\hline 123 & 53 & 0 & 0 & 0 & 0 & 0 & 0 & 0 & 0.042 & 0.176 & 0.135 & 0.109 \\
\hline 124 & 11 & 0 & 0 & -0.001 & -0.063 & -0.023 & -0.030 & -0.030 & -0.034 & -0.029 & -0.023 & -0.058 \\
\hline 124 & 13 & 0.379 & -0.959 & -0.643 & -0.608 & -0.520 & -0.094 & -0.662 & -0.095 & 0 & -0.008 & 0 \\
\hline 124 & 14 & -0.341 & -0.964 & -1.234 & -1.684 & -1.085 & -0.315 & -1.078 & -0.160 & -0.165 & -0.344 & -0.510 \\
\hline 124 & 16 & 0 & 0 & 0 & 0 & 0 & -0.011 & -0.028 & -0.029 & -0.033 & -0.031 & -0.025 \\
\hline 124 & 47 & 0 & 0 & 0 & 0 & 0 & 0 & 0 & 0 & 0 & 0 & 0 \\
\hline 125 & 7 & 0 & 0 & 0 & 0 & 0 & 0 & 0 & 0 & -0.008 & -0.036 & -0.023 \\
\hline 125 & 39 & 0.004 & 0.007 & 0.0 & 0.0 & 0.012 & 0. & 0.027 & 0.028 & 0.022 & 0.027 & 0.026 \\
\hline 125 & 42 & 0 & 0 & 0 & 0 & 0 & 0 & 0 & 0 & -0.064 & -0.127 & -0.111 \\
\hline 126 & 13 & 0 & 0 & 0 & 0 & 0 & -0.015 & -0.022 & -0.022 & -0.022 & -0.022 & -0.020 \\
\hline 126 & 31 & 0 & 0 & 0 & 0 & 0 & 0.059 & 0.106 & 0.165 & 0.227 & 0.286 & 0.332 \\
\hline 126 & 42 & 0 & 0 & 0 & 0 & 0 & -0.657 & -0.565 & -0.325 & -0.110 & 0 & 0 \\
\hline 126 & 52 & 0 & 0 & 0 & $\sigma$ & 0 & 0 & 0.094 & 0.069 & 0.067 & 0.073 & 0.087 \\
\hline 126 & 54 & 0 & 0 & 0 & 0 & 0 & 0 & 0 & 0 & 0 & 0.057 & 0.172 \\
\hline 126 & 55 & 0 & 0 & 0 & 0 & 0 & 0 & 0.062 & 0.179 & 0.084 & 0.116 & 0.106 \\
\hline 127 & 39 & 0.009 & 0.018 & 0.023 & 0.031 & 0.046 & 0.065 & 0.072 & 0.082 & 0.092 & 0.092 & 0.114 \\
\hline 128 & 11 & 0 & 0 & 0 & 0 & 0 & -0.046 & -0.046 & -0.046 & -0.046 & -0.046 & -0.046 \\
\hline
\end{tabular}


Table 5. - Schedule of nonagricultural ground-water withdrawal specified in the model-Continued

\begin{tabular}{|c|c|c|c|c|c|c|c|c|c|c|c|c|}
\hline & $\mathrm{C}$ & & & & & & & & & & & \\
\hline $\mathrm{L}$ & o & & & & & & & & & & & \\
\hline a & 1 & & & & & & & & & & & \\
\hline y R & $\mathbf{u}$ & 1965 & 1967 & 1969 & & 1973 & & 1977 & 1979 & 1981 & 1983 & \\
\hline e o & m & - & - & - & & - & & - & - & - & - & \\
\hline$r \quad w$ & $\mathrm{n}$ & 1966 & 1968 & 1971 & 1972 & 1975 & 1976 & 1978 & 1980 & 1982 & 1984 & 1985 \\
\hline 128 & 43 & -0.802 & -0.714 & -0.216 & 0.002 & 0.002 & 0.002 & 0.002 & 0.002 & 0.002 & 0.002 & 0.002 \\
\hline 128 & 46 & 0 & 0 & 0 & 0 & 0 & 0 & 0 & 0 & 0 & 0 & 0 \\
\hline 129 & 43 & -0.802 & -0.714 & -0.701 & -0.658 & -0.710 & -0.742 & -0.445 & -0.401 & -0.381 & -0.375 & -0.384 \\
\hline 211 & 7 & 0 & 0 & 0 & 0 & 0 & 0 & 0 & -0.345 & -0.941 & -0.873 & -0.873 \\
\hline 212 & 8 & 0 & 0 & 0 & 0 & 0 & 0 & 0 & 0 & 0 & -0.747 & -0.747 \\
\hline 212 & 9 & 0 & 0 & 0 & 0 & 0 & 0 & 0 & 0 & -0.008 & -0.062 & -0.023 \\
\hline 212 & 10 & 0 & 0 & 0 & 0 & 0 & -0.039 & -0.039 & -0.039 & -0.039 & -0.039 & -0.039 \\
\hline 213 & 8 & 0 & 0 & 0 & 0 & -0.787 & -0.387 & -0.420 & -0.640 & -1.080 & -0.973 & -1.036 \\
\hline 213 & 9 & 0 & 0 & 0 & 0 & -0.380 & -0.387 & -0.420 & -0.226 & -0.329 & -0.945 & -1.019 \\
\hline 213 & 47 & 0 & 0 & 0 & 0 & 0 & 0 & 0 & 0 & 0 & -0.136 & -0.156 \\
\hline 214 & 7 & 0 & 0 & 0 & 0 & -0.787 & -0.441 & -0.479 & -0.558 & -0.561 & -1.374 & -1.505 \\
\hline 214 & 8 & 0 & 0 & 0 & 0 & 0 & -0.053 & -0.166 & -0.270 & -0.293 & -0.294 & -0.223 \\
\hline 215 & 6 & 0 & 0 & 0 & 0 & 0 & -0.595 & -0.627 & -0.586 & -0.529 & -0.628 & -0.588 \\
\hline 215 & 7 & 0 & 0 & 0 & 0 & -0.787 & -0.387 & -0.438 & -0.417 & -0.263 & -0.193 & -0.254 \\
\hline 216 & 4 & 0 & 0 & 0 & 0 & 0 & 0 & 0 & -0.313 & -0.254 & 0 & 0 \\
\hline 216 & 7 & 0 & 0 & 0 & 0 & 0 & 0 & -0.489 & -0.417 & -0.410 & -0.113 & -0.097 \\
\hline 217 & 7 & 0 & 0 & 0 & 0 & 0 & 0 & -0.489 & -0.417 & 0 & 0 & 0 \\
\hline 219 & 11 & 0 & 0 & 0 & 0 & 0 & 0 & 0 & 0 & -0.002 & -0.004 & -0.006 \\
\hline 219 & 16 & -0.052 & -0.052 & -0.052 & -0.052 & -0.052 & -0.052 & -0.052 & -0.052 & -0.052 & -0.052 & -0.052 \\
\hline 219 & 49 & -0.029 & -0.029 & -0.029 & -0.029 & -0.029 & -0.029 & -0.029 & -0.029 & -0.029 & -0.029 & -0.029 \\
\hline 221 & 13 & -1.847 & -0.559 & -0.126 & -0.133 & -0.066 & 0 & -0.482 & -1.047 & -0.386 & -0.912 & -1.657 \\
\hline 221 & 23 & -0.030 & -0.030 & -0.030 & -0.030 & -0.030 & -0.030 & -0.030 & -0.030 & -0.030 & -0.030 & -0.030 \\
\hline 222 & 13 & 0 & 0 & -0.079 & -0.811 & -0.210 & -0.164 & -2.286 & -1.462 & -1.789 & -1.828 & -0.093 \\
\hline 222 & 31 & -0.059 & -0.059 & -0.059 & -0.059 & -0.059 & -0.059 & -0.059 & -0.059 & -0.059 & -0.059 & -0.059 \\
\hline 222 & 43 & -0.122 & -0.122 & -0.122 & -0.122 & -0.122 & -0.122 & -0.122 & -0.122 & -0.122 & -0.122 & -0.122 \\
\hline 223 & 9 & 0 & 0 & 0 & 0 & 0 & U & 0 & 0 & 0 & -0.017 & -0.017 \\
\hline 223 & 10 & 0 & 0 & 0 & 0 & 0 & -0.028 & -0.038 & -0.079 & -0.078 & -0.109 & -0.117 \\
\hline 223 & 12 & -0.865 & -0.790 & -1.738 & -1.968 & -0.768 & -1.101 & -1.727 & -1.756 & -2.463 & -2.401 & -1.629 \\
\hline 223 & 28 & -0.059 & -0.059 & -0.059 & -0.059 & -0.059 & -0.059 & -0.059 & -0.059 & -0.059 & -0.059 & -0.059 \\
\hline 223 & 42 & -0.068 & -0.081 & -0.078 & -0.087 & -0.126 & -0.057 & -0.151 & -0.183 & -0.201 & -0.249 & -0.231 \\
\hline 223 & 47 & 0 & 0 & 0 & 0 & 0 & -0.569 & -1.650 & -2.165 & -2.373 & -2.207 & -1.095 \\
\hline 223 & 50 & 0 & 0 & 0 & 0 & 0 & 0 & -0.671 & -0.307 & -0.736 & -0.625 & -0.685 \\
\hline 223 & 51 & -0.029 & -0.034 & -0.033 & -0.039 & -0.064 & -0.107 & -0.134 & -0.147 & -0.151 & -0.158 & -0.155 \\
\hline 223 & 52 & -0.029 & -0.029 & -0.029 & -0.029 & -0.029 & -0.029 & -0.029 & -0.029 & -0.029 & -0.029 & -0.029 \\
\hline 223 & 53 & 0 & 0 & 0 & 0 & 0 & 0 & 0 & -0.085 & -0.353 & -0.269 & -0.218 \\
\hline
\end{tabular}




\begin{tabular}{|c|c|c|c|c|c|c|c|c|c|c|c|c|}
\hline $\begin{array}{l}\mathrm{L} \\
\mathrm{a}\end{array}$ & $\begin{array}{l}\mathrm{C} \\
0 \\
1\end{array}$ & & & & & & & & & & & \\
\hline y R & $\mathbf{u}$ & 1965 & 1967 & 1969 & & 1973 & & 1977 & 1979 & 1981 & 1983 & \\
\hline e o & m & - & - & - & & - & & - & - & - & - & \\
\hline$r \quad w$ & $\mathrm{n}$ & 1966 & 1968 & 1971 & 1972 & 1975 & 1976 & 1978 & 1980 & 1982 & 1984 & 1985 \\
\hline 223 & & -0.022 & -0.022 & 0.022 & 0.022 & -0.022 & -0.022 & -0.022 & -0.022 & -0.022 & -0.022 & -0.022 \\
\hline 224 & & -0.248 & 0.711 & 0.745 & 2.187 & -0.086 & -0.113 & -2.632 & -3.160 & -1.618 & -2.485 & -1.718 \\
\hline 224 & 15 & -3.164 & -3.023 & 3.610 & 3.511 & -1.691 & -2.884 & -5.021 & -3.319 & -2.065 & -3.242 & -2.654 \\
\hline 224 & 16 & 0 & 0 & -0.014 & -0.096 & -0.376 & -0.578 & -1.955 & -1.114 & -0.660 & -0.488 & -0.89 \\
\hline 224 & 17 & -0.386 & -0.799 & -0.384 & -2.156 & 0 & -0.421 & -2.986 & -2.397 & -0.895 & -0.965 & -0.805 \\
\hline 224 & 41 & -0.178 & -0.178 & 0.137 & -0.116 & -0.116 & -0.116 & -0.116 & -0.116 & -0.116 & -0.116 & -0.116 \\
\hline 225 & 39 & -0.008 & -0.014 & -0.013 & -0.0 & -0.025 & -0.1 & -0.053 & -0.057 & -0 . & -0.054 & -0.052 \\
\hline 225 & 41 & 0 & 0 & 0 & 0 & 0 & 0 & -0.574 & -0.276 & -1.047 & -1.444 & -1.937 \\
\hline 225 & 42 & -0.804 & -0.716 & -0.703 & -0.660 & -0.712 & 0 & 0 & 0 & 0 & 0 & \\
\hline 225 & 45 & 0 & 0 & 0 & 0 & 0 & 0 & 0 & -0.640 & -1.314 & -0.902 & -0.643 \\
\hline 225 & 50 & 0 & 0 & 0 & 0 & 0 & 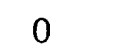 & 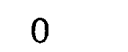 & -0.238 & -0.403 & -0.584 & .571 \\
\hline 226 & 10 & 0 & 0 & -0.009 & -0.028 & -0.028 & -0.1 & -0.028 & -0.028 & -0.028 & -0.028 & -0.028 \\
\hline 226 & 16 & 0 & 0 & 0 & 0 & -0.003 & -0. & -0.021 & -0.002 & 0 & 0 & 0 \\
\hline 226 & 17 & -0.378 & -0.296 & -0.370 & -0.243 & -0.240 & -0 . & -0.988 & -0.996 & -0.699 & -0.792 & -0.602 \\
\hline 226 & 31 & -0.022 & -0.022 & -0.015 & -0.001 & -0.001 & -0 & -0.212 & -0.330 & -0.453 & -0.572 & -0.665 \\
\hline 226 & 41 & -1.162 & -1.256 & -1.6 & 9 & -2.0 & -2 & -2.253 & -2.313 & -2 & -2.584 & -2.727 \\
\hline 226 & 43 & 0 & 0 & 0 & 0 & 0 & 0 & 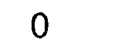 & 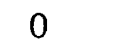 & -0.941 & -1.159 & -0.830 \\
\hline 226 & 47 & -0.803 & -0.715 & -0.702 & -0.659 & -0.711 & - & -0.359 & -0.522 & -0.213 & -0.246 & -0.175 \\
\hline 226 & 49 & -0.803 & -0.715 & -0.702 & -0.659 & -0.711 & -0.0 & -0.133 & -0.162 & 0 & 0 & 0 \\
\hline 226 & 52 & 0 & 0 & 0 & 0 & 0 & 0 & -0.188 & -0.139 & -0.135 & -0.146 & -0.174 \\
\hline 226 & 54 & 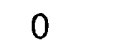 & - & 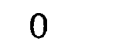 & 0 & 0 & 0 & 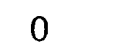 & 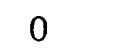 & 0 & -0.115 & -0.344 \\
\hline 226 & 55 & -0.033 & -0.033 & -0.036 & -0.054 & -0.074 & 0 & -0.123 & -0.358 & -0.167 & -0.231 & -0.213 \\
\hline 227 & 14 & . & 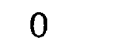 & . & 0 & 0 & 0 & 0 & 0 & 0 & 0 & 0 \\
\hline 227 & 15 & -0.125 & -0.153 & -0.309 & -0.580 & -0.598 & -0.6 & -0.634 & -0.373 & -0.654 & -0.652 & -0.652 \\
\hline 227 & 16 & 0 & 0 & 0 & 0 & 0 & 0 & 0 & 0 & 0 & -0.002 & -0.010 \\
\hline 227 & 17 & 202 & -3.14 & 2.4 & & & -10 & -2.505 & -1.465 & -0.765 & 0 & 0 \\
\hline 227 & 18 & 237 & -0.290 & -0.356 & -0.291 & -0.128 & 0 & 0 & 0 & 0 & 0 & 0 \\
\hline 227 & 19 & -0.067 & -0.097 & -0.129 & -0.139 & -0.142 & -0 & -0.362 & -0.491 & -0.616 & -0.743 & -0.835 \\
\hline 227 & 36 & -0.025 & -0.025 & -0.025 & -0.025 & -0.025 & -0.025 & -0.025 & -0.025 & -0.025 & -0.025 & -0.025 \\
\hline 227 & 39 & -0.018 & -0.035 & -0.046 & -0.061 & -0.092 & -0.130 & -0.144 & -0.165 & -0.184 & -0.185 & -0.228 \\
\hline 227 & 50 & -0.803 & -0.715 & -0.702 & -0.659 & -0. & 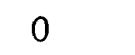 & 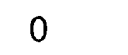 & 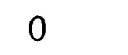 & 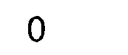 & 0 & 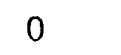 \\
\hline 228 & 14 & -0.074 & -0.087 & -0.098 & -0.102 & -0.144 & -0.1 & -0.140 & -0.165 & -0.179 & -0.179 & -0.20 \\
\hline 228 & 15 & 0 & 0 & 0 & 0 & 0 & 0 & 0 & 0 & -0.001 & -0.017 & -0.00 \\
\hline 228 & 17 & -0.501 & -0.457 & -0.523 & -0.597 & -0.501 & 0 & 0 & 0 & 0 & 0 & 0 \\
\hline 228 & 44 & -0.395 & -0.716 & -0.703 & -0.660 & -0.712 & -0.476 & -0.551 & -0.693 & -1.146 & -1.222 & -1.438 \\
\hline
\end{tabular}


Table 5. - Schedule of nonagricultural ground-water withdrawal specified in the model-Concluded

\begin{tabular}{|c|c|c|c|c|c|c|c|c|c|c|c|c|}
\hline & C & & & & & & & & & & & \\
\hline $\begin{array}{l}\mathrm{L} \\
\mathrm{a}\end{array}$ & 0 & & & & & & & & & & & \\
\hline y $R$ & $\mathrm{u}$ & 1965 & 1967 & 1969 & & 1973 & & 1977 & 1979 & 1981 & 1983 & \\
\hline e o & $\mathrm{m}$ & - & - & - & & - & & - & - & - & - & \\
\hline$r \quad w$ & $\mathrm{n}$ & 1966 & 1968 & 1971 & 1972 & 1975 & 1976 & 1978 & 1980 & 1982 & 1984 & 1985 \\
\hline 228 & & 0 & 0 & -0.703 & -0.660 & -0.712 & -0.710 & -0.948 & -0.610 & -0.485 & -0.749 & -0.398 \\
\hline 228 & 46 & -0.803 & -0.715 & -0.932 & -1.318 & -1.421 & -1.673 & -1.064 & -1.060 & -1.029 & -1.576 & -1.482 \\
\hline 228 & 48 & 0 & 0 & -0.230 & -0.659 & -0.711 & -0.618 & -0.574 & -1.022 & -0.705 & -0.871 & -0.615 \\
\hline 228 & 49 & 0 & 0 & -0.703 & -0.660 & -0.712 & -1.420 & -0.867 & -0.588 & -1.116 & -1.459 & -2.165 \\
\hline 228 & 50 & -1.198 & -1.431 & -1.405 & -1.318 & -1.421 & -1.715 & -1.468 & -1.800 & -1.838 & -2.051 & -2.203 \\
\hline 229 & 23 & -0.021 & -0.021 & -0.021 & -0.021 & -0.021 & -0.021 & -0.021 & -0.021 & -0.021 & -0.021 & -0.021 \\
\hline 229 & 43 & -0.803 & -0.715 & -0.702 & -0.659 & -0.711 & -1.133 & -1.171 & -1.138 & -0.603 & -0.875 & -0.857 \\
\hline 229 & 44 & -0.803 & -0.715 & -0.702 & -0.659 & -0.711 & -1.299 & -1.221 & -1.121 & -0.347 & -0.347 & -0.347 \\
\hline 229 & 45 & -0.804 & -0.716 & -0.703 & -0.660 & -0.712 & -1.973 & -1.501 & -1.432 & -0.943 & -1.403 & -1.419 \\
\hline 229 & 46 & -1.607 & -1.432 & -1.406 & -1.319 & -1.422 & -3.094 & -2.519 & -2.142 & -1.825 & -2.104 & -1.975 \\
\hline 230 & 44 & 0 & 0 & 0 & 0 & 0 & 0 & 0 & 0 & 0 & -0.333 & -1.374 \\
\hline 324 & 15 & -5.566 & -4.974 & -6.494 & -5.247 & -6.429 & -7.053 & -5.076 & -6.549 & -8.116 & -5.255 & -7.551 \\
\hline 324 & 16 & -2.174 & -1.343 & -1.610 & -1.888 & -3.460 & -4.195 & -2.970 & -2.652 & -2.938 & -2.535 & -2.172 \\
\hline 324 & 17 & -4.480 & -3.657 & -1.626 & -1.367 & -2.494 & -3.211 & -1.506 & -3.131 & -2.432 & -1.398 & -0.866 \\
\hline 325 & 16 & -2.588 & -1.858 & -2.595 & -1.654 & -3.153 & -3.520 & -2.178 & -2.033 & -2.690 & -2.484 & -1.117 \\
\hline 326 & 14 & 0 & 0 & 0 & 0 & 0 & 0 & 0 & 0 & -0.022 & -0.022 & -0.015 \\
\hline 326 & 16 & 0 & 0 & 0 & 0 & -0.015 & -0.048 & -0.055 & -0.070 & -0.054 & -0.060 & -0.053 \\
\hline 326 & 17 & 0 & 0 & 0 & 0 & 0 & 0 & 0 & 0 & 0 & 0 & -0.258 \\
\hline 327 & 17 & 0 & 0 & 0 & 0 & 0 & 0 & 0 & 0 & -0.023 & -0.435 & -0.408 \\
\hline 327 & 18 & 0 & 0 & 0 & 0 & -0.252 & -0.402 & -0.502 & -0.578 & -0.631 & -0.610 & -0.692 \\
\hline Tota & & -47.63 & -48.99 & -49.74 & -55.9 & -53.48 & -54.58 & -68.52 & -62.56 & -59.58 & -60.69 & -59.86 \\
\hline
\end{tabular}


Table 6.--Differences between measured and model-derived hydraulic heads

[* indicates sites used for sensitivity tests]

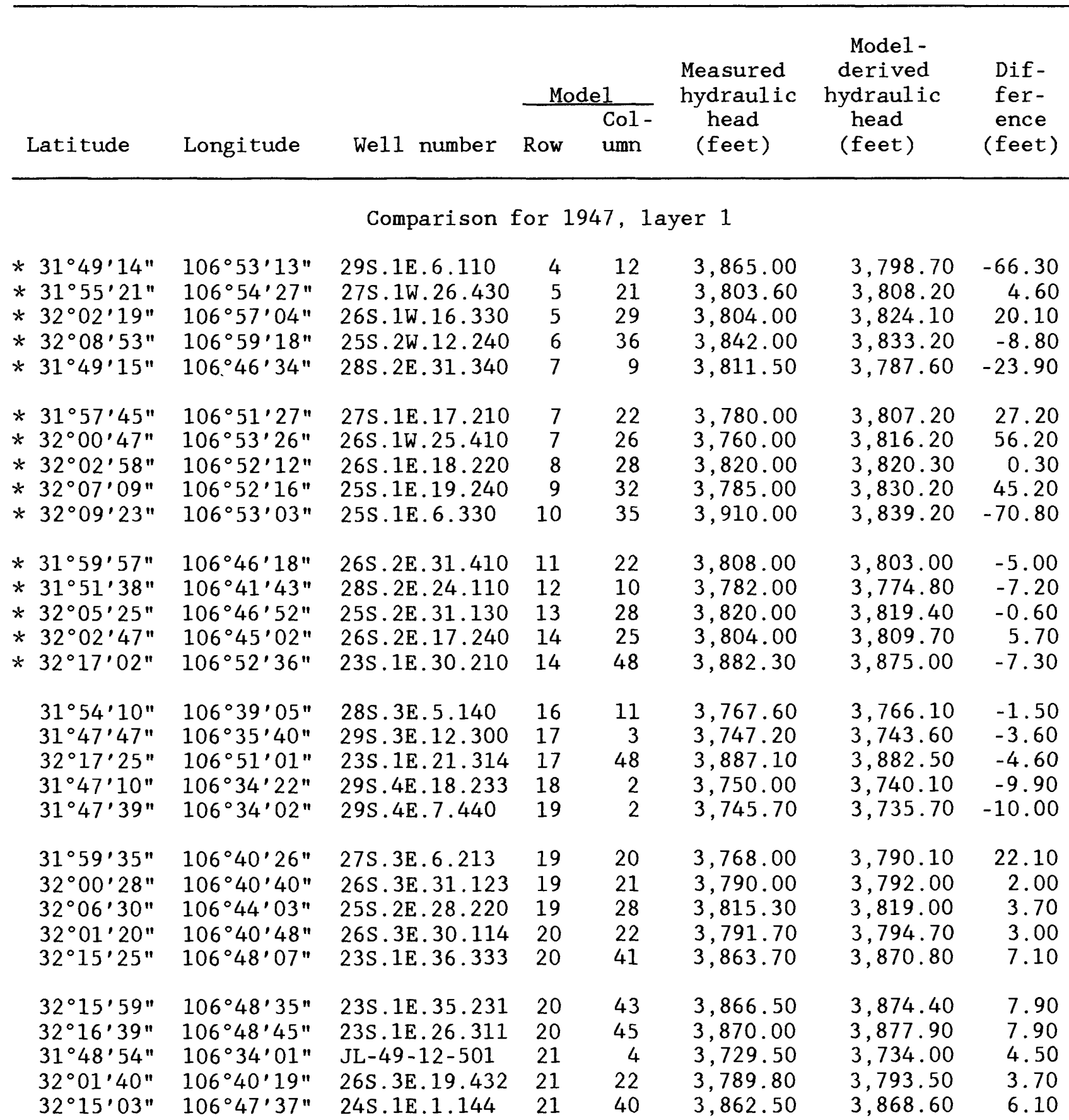


Table 6.--Differences between measured and mode1-derived hydraulic heads--Continued

\begin{tabular}{|c|c|c|c|c|c|c|c|}
\hline \multirow[b]{2}{*}{ Latitude } & \multirow[b]{2}{*}{ Longitude } & \multirow[b]{2}{*}{ We11 number } & \multicolumn{2}{|c|}{ Mode1 } & \multirow{2}{*}{$\begin{array}{l}\text { Measured } \\
\text { hydraulic } \\
\text { head } \\
\text { (feet) }\end{array}$} & \multirow{2}{*}{$\begin{array}{c}\text { Model- } \\
\text { derived } \\
\text { hydraulic } \\
\text { head } \\
\text { (feet) }\end{array}$} & \multirow{2}{*}{$\begin{array}{l}\text { Dif- } \\
\text { fer- } \\
\text { ence } \\
\text { (feet) }\end{array}$} \\
\hline & & & Row & $\begin{array}{l}\text { Col- } \\
\text { umn }\end{array}$ & & & \\
\hline $32^{\circ} 19^{\prime} 02^{\prime \prime}$ & $106^{\circ} 49^{\prime} 13^{\prime \prime}$ & $23 \mathrm{~S} .1 \mathrm{E} .10 .442$ & 21 & 50 & $3,885.10$ & $3,888.60$ & 3.50 \\
\hline $32^{\circ} 22^{\prime} 04^{\prime \prime}$ & $106^{\circ} 50^{\prime} 45^{\prime \prime}$ & 22S.1E. 28.142 & 21 & 54 & $3,907.60$ & $3,908.10$ & 0.50 \\
\hline $31^{\circ} 57^{\prime} 37^{\prime \prime}$ & $106^{\circ} 37^{\prime} 36^{\prime \prime}$ & 27S.3E.15.143 & 22 & 16 & $3,771.60$ & $3,775.60$ & 4.00 \\
\hline $32^{\circ} 09^{\prime} 44^{\prime \prime}$ & $106^{\circ} 44^{\prime} 03^{\prime \prime}$ & $25 \mathrm{~S} .2 \mathrm{E} .4 .422$ & 22 & 32 & $3,824.40$ & $3,836.30$ & 11.90 \\
\hline $32^{\circ} 24^{\prime} 29^{\prime \prime}$ & $106^{\circ} 51^{\prime} 44^{\prime \prime}$ & 22S.1E.8.421 & 22 & 57 & $3,916.50$ & $3,923.20$ & 6.70 \\
\hline $32^{\circ} 26^{\prime} 18^{\prime \prime}$ & $106^{\circ} 52^{\prime} 27^{\prime \prime}$ & $21 \mathrm{~S} .1 \mathrm{E} .31 .412$ & 22 & 60 & $3,935.40$ & $3,937.60$ & 2.20 \\
\hline $32^{\circ} 28^{\prime} 42^{\prime \prime}$ & $106^{\circ} 53^{\prime} 54^{\prime \prime}$ & $21 \mathrm{~s} .1 \mathrm{~W} .13 .323$ & 22 & 62 & $3,947.60$ & $3,945.30$ & -2.30 \\
\hline $32^{\circ} 29^{\prime} 34^{\prime \prime}$ & $106^{\circ} 54^{\prime} 40^{\prime \prime}$ & $21 \mathrm{~S} .1 \mathrm{~W} .11 .431$ & 22 & 63 & $3,956.00$ & $3,950.80$ & -5.20 \\
\hline $32^{\circ} 16^{\prime} 06^{\prime \prime}$ & $106^{\circ} 46^{\prime} 35^{\prime \prime}$ & 23 S.2E. 31.213 & 23 & 42 & $3,865.90$ & $3,872.60$ & 6.70 \\
\hline $32^{\circ} 23^{\prime} 10^{\prime \prime}$ & $106^{\circ} 50^{\prime} 37^{\prime \prime}$ & 22 S.1E. 21.211 & 23 & 56 & $3,909.60$ & $3,918.00$ & 8.40 \\
\hline $32^{\circ} 06^{\prime} 56^{\prime \prime}$ & $106^{\circ} 41^{\prime} 28^{\prime \prime}$ & 25 S. 2E. 24.413 & 24 & 28 & $3,813.80$ & $3,819.20$ & 5.40 \\
\hline $32^{\circ} 16^{\prime} 45^{\prime \prime}$ & $106^{\circ} 46^{\prime} 20^{\prime \prime}$ & 23 S. 2 E. 30.412 & 24 & 43 & $3,867.40$ & $3,873.30$ & 5.90 \\
\hline $32^{\circ} 06^{\prime} 52^{\prime \prime}$ & $106^{\circ} 40^{\prime} 58^{\prime \prime}$ & 25S.3E.19.331 & 25 & 27 & $3,814.10$ & $3,814.90$ & 0.80 \\
\hline $32^{\circ} 14^{\prime} 43^{\prime \prime}$ & $106^{\circ} 45^{\prime} 06^{\prime \prime}$ & 24 S. 2E. 5.422 & 25 & 38 & $3,858.40$ & $3,858.60$ & 0.20 \\
\hline $32^{\circ} 19^{\prime} 48^{\prime \prime}$ & $106^{\circ} 47^{\prime} 19^{\prime \prime}$ & $23 \mathrm{~S} .1 \mathrm{E} .1 .443$ & 25 & 50 & $3,887.50$ & $3,894.70$ & 7.20 \\
\hline $32^{\circ} 23^{\prime} 23^{\prime \prime}$ & $106^{\circ} 49^{\prime} 37^{\prime \prime}$ & 22S.1E.15.431 & 25 & 55 & $3,908.40$ & $3,917.20$ & 8.80 \\
\hline $32^{\circ} 10^{\prime} 11^{\prime \prime}$ & $106^{\circ} 42^{\prime} 14^{\prime \prime}$ & $25 \mathrm{~S} .2 \mathrm{E} .2 .221$ & 26 & 31 & $3,829.00$ & $3,827.70$ & -1.30 \\
\hline $32^{\circ} 12^{\prime} 00^{\prime \prime}$ & $106^{\circ} 43^{\prime} 05^{\prime \prime}$ & 24S.2E. 22.444 & 26 & 34 & $3,839.00$ & $3,842.90$ & 3.90 \\
\hline $32^{\circ} 16^{\prime} 46^{\prime \prime}$ & $106^{\circ} 45^{\prime} 18^{\prime \prime}$ & 23S.2E.29.243 & 26 & 42 & $3,867.60$ & $3,869.90$ & 2.30 \\
\hline $32^{\circ} 18^{\prime} 46^{\prime \prime}$ & $106^{\circ} 45^{\prime} 19^{\prime \prime}$ & $23 \mathrm{~S} .2 \mathrm{E} .17 .210$ & 28 & 46 & $3,863.10$ & $3,870.60$ & 7.50 \\
\hline $32^{\circ} 18^{\prime} 59^{\prime \prime}$ & $106^{\circ} 45^{\prime} 19^{\prime \prime}$ & $23 \mathrm{~S} .2 \mathrm{E} .8 .434$ & 28 & 47 & $3,870.30$ & $3,882.50$ & 12.20 \\
\hline $32^{\circ} 20^{\prime} 45^{\prime \prime}$ & $106^{\circ} 46^{\prime} 37^{\prime \prime}$ & 22 S. 2 E. 31.340 & 28 & 51 & $3,896.00$ & $3,898.00$ & 2.00 \\
\hline $32^{\circ} 10^{\prime} 10^{\prime \prime}$ & $106^{\circ} 40^{\prime} 16^{\prime \prime}$ & 24 S.3E. 31.430 & 29 & 31 & $3,817.00$ & $3,832.20$ & 15.20 \\
\hline * $32^{\circ} 07^{\prime} 19^{\prime \prime}$ & $106^{\circ} 37^{\prime} 25^{\prime \prime}$ & 25 S. 3E. 22.120 & 32 & 26 & $3,825.00$ & $3,815.70$ & -9.30 \\
\hline \multicolumn{8}{|c|}{ Comparison of 1975 , layer 1} \\
\hline * $31^{\circ} 53^{\prime} 55^{\prime \prime}$ & $106^{\circ} 59^{\prime} 06^{\prime \prime}$ & $28 \mathrm{~S} .1 \mathrm{~W} .6 .323$ & 3 & 21 & $3,813.37$ & $3,810.60$ & -2.77 \\
\hline * $31^{\circ} 59^{\circ} 08^{\prime \prime}$ & $107^{\circ} 00^{\prime} 50^{\prime \prime}$ & 27 S. 2 W. 2.411 & 3 & 27 & $3,823.60$ & $3,825.50$ & 1.90 \\
\hline$* 32^{\circ} 03^{\circ} 06^{\prime \prime}$ & $107^{\circ} 03^{\prime} 36^{\prime \prime}$ & 26 S. $2 W .17 .214$ & 3 & 32 & $3,828.80$ & $3,844.30$ & 15.50 \\
\hline$* 32^{\circ} 02^{\prime} 30^{\prime \prime}$ & $107^{\circ} 01^{\prime} 31^{\prime \prime}$ & $26 \mathrm{~S} .2 \mathrm{~W} .15 .443$ & 4 & 31 & $3,833.70$ & $3,829.90$ & -3.80 \\
\hline * $31^{\circ} 55^{\prime} 36^{\prime \prime}$ & $106^{\circ} 54^{\prime} 46^{\prime \prime}$ & $27 \mathrm{~S} .1 \mathrm{~W} .26 .413$ & 5 & 21 & $3,810.69$ & $3,807.70$ & -2.99 \\
\hline * $32^{\circ} 00^{\prime} 54^{\prime \prime}$ & $106^{\circ} 53^{\prime} 39^{\prime \prime}$ & $26 \mathrm{~S} .1 \mathrm{~W} .25 .414$ & 7 & 26 & $3,822.00$ & $3,815.70$ & -6.30 \\
\hline$* 32^{\circ} 07^{\prime} 46^{\prime \prime}$ & $106^{\circ} 57^{\prime} 20^{\prime \prime}$ & 25 S.1W.16.331 & 7 & 35 & $3,835.00$ & $3,833.70$ & -1.30 \\
\hline * $32^{\circ} 03^{\prime} 09^{\prime \prime}$ & $106^{\circ} 52^{\prime} 16^{\prime \prime}$ & $26 \mathrm{~S} .1 \mathrm{E} .18 .222$ & 8 & 28 & $3,814.47$ & $3,819.80$ & 5.33 \\
\hline * $31^{\circ} 59^{\prime} 55^{\prime \prime}$ & $106^{\circ} 49^{\prime} 03^{\prime \prime}$ & 26S.1E.35.333 & 9 & 23 & $3,795.50$ & $3,806.10$ & 10.60 \\
\hline * $32^{\circ} 12^{\circ} 39^{\prime \prime}$ & $106^{\circ} 56^{\prime} 01^{\prime \prime}$ & $24 \mathrm{~S} .1 \mathrm{~W} .22 .123$ & 9 & 41 & $3,872.53$ & $3,847.70$ & -24.83 \\
\hline
\end{tabular}


Table 6.--Differences between measured and model-derived hydraulic heads--Continued

\begin{tabular}{|c|c|c|c|c|c|c|c|}
\hline \multirow[b]{2}{*}{ Latitude } & \multirow[b]{2}{*}{ Longitude } & \multirow[b]{2}{*}{ We11 number } & \multicolumn{2}{|c|}{ Model } & \multirow{2}{*}{$\begin{array}{l}\text { Measured } \\
\text { hydraulic } \\
\text { head } \\
\text { (feet) }\end{array}$} & \multirow{2}{*}{$\begin{array}{l}\text { Model- } \\
\text { derived } \\
\text { hydraulic } \\
\text { head } \\
\text { (feet) }\end{array}$} & \multirow{2}{*}{$\begin{array}{l}\text { Dif- } \\
\text { fer- } \\
\text { ence } \\
\text { (feet) }\end{array}$} \\
\hline & & & Row & $\begin{array}{l}\text { Col - } \\
\text { umn }\end{array}$ & & & \\
\hline * $32^{\circ} 06^{\prime} 51^{\prime \prime}$ & $106^{\circ} 51^{\prime} 11^{\prime \prime}$ & 25S.1E. 21.331 & 10 & 31 & $3,836.17$ & $3,827.40$ & -8.77 \\
\hline * $32^{\circ} 11^{\prime} 23^{\prime \prime}$ & $106^{\circ} 53^{\prime} 23^{\prime \prime}$ & 24 S.1W. 25.422 & 10 & 37 & $3,848.00$ & $3,843.90$ & -4.10 \\
\hline$* 31^{\circ} 49^{\prime} 52^{\prime \prime}$ & $106^{\circ} 41^{\prime} 35^{\prime \prime}$ & 28 S. 2E. 36.142 & 11 & 8 & $3,776.35$ & $3,772.90$ & -3.45 \\
\hline * $31^{\circ} 51^{\prime} 18^{\prime \prime}$ & $106^{\circ} 42^{\prime} 26^{\prime \prime}$ & 28S.2E. 23.324 & 11 & 10 & $3,782.47$ & $3,775.90$ & -6.57 \\
\hline * $32^{\circ} 08^{\prime} 26^{\prime \prime}$ & $106^{\circ} 51^{\prime} 12^{\prime \prime}$ & 25 S.1E.16.114 & 11 & 33 & $3,836.69$ & $3,833.70$ & -2.99 \\
\hline * $32^{\circ} 05^{\prime} 28^{\prime \prime}$ & $106^{\circ} 47^{\prime} 02^{\prime \prime}$ & 25S.2E. 31.133 & 13 & 28 & $3,814.30$ & $3,818.40$ & 4.10 \\
\hline * $31^{\circ} 50^{\prime} 50^{\prime \prime}$ & $106^{\circ} 38^{\prime} 49^{\prime \prime}$ & 28 S. 3E. 28.114 & 14 & 8 & $3,754.95$ & $3,757.90$ & 2.95 \\
\hline $31^{\circ} 52^{\prime} 12^{\prime \prime}$ & $106^{\circ} 38^{\prime} 19^{\prime \prime}$ & $28 \mathrm{~S} .3 \mathrm{E} .16 .414$ & 16 & 9 & $3,749.45$ & $3,750.20$ & 0.75 \\
\hline $32^{\circ} 16^{\prime} 07^{\prime \prime}$ & $106^{\circ} 50^{\prime} 26^{\prime \prime}$ & 23S.1E. 33.214 & 16 & 45 & $3,876.70$ & $3,873.30$ & -3.40 \\
\hline $31^{\circ} 54^{\prime} 27^{\prime \prime}$ & $106^{\circ} 38^{\prime} 57^{\prime \prime}$ & $28 \mathrm{~S} .3 \mathrm{E} .4 .111$ & 17 & 11 & $3,759.36$ & $3,760.00$ & 0.64 \\
\hline $31^{\circ} 54^{\prime} 57^{\prime \prime}$ & $106^{\circ} 39^{\prime} 05^{\prime \prime}$ & 27 S. 3E. 32.244 & 17 & 12 & $3,762.65$ & $3,763.60$ & 0.95 \\
\hline $32^{\circ} 17^{\prime} 36^{\prime \prime}$ & $106^{\circ} 50^{\prime} 59^{\prime \prime}$ & 23 S.1E. 20.134 & 17 & 48 & $3,877.15$ & $3,880.30$ & 3.15 \\
\hline $31^{\circ} 51^{\prime} 52^{\prime \prime}$ & $106^{\circ} 37^{\prime} 19^{\prime \prime}$ & $\mathrm{JL}-49-12-108$ & 18 & 8 & $3,746.61$ & $3,744.70$ & -1.91 \\
\hline $31^{\circ} 58 \cdot 37^{\prime \prime}$ & $106^{\circ} 40^{\prime} 25^{\prime \prime}$ & 27S. 3E. 7.231 & 18 & 18 & $3,779.71$ & $3,778.80$ & -0.91 \\
\hline $32^{\circ} 15^{\prime} 39^{\prime \prime}$ & $106^{\circ} 49^{\prime} 22^{\prime \prime}$ & 23 S. IE. 34.423 & 18 & 43 & $3,874.85$ & $3,872.00$ & -2.85 \\
\hline $31^{\circ} 48^{\prime} 25^{\prime \prime}$ & $106^{\circ} 34^{\prime} 50^{\prime \prime}$ & 29S.4E.7.111 & 19 & 4 & $3,731.53$ & $3,733.60$ & 2.07 \\
\hline $31^{\circ} 55^{\prime} 30^{\prime \prime}$ & $106^{\circ} 38^{\prime} 33^{\prime \prime}$ & 27 S. 3E. 28.341 & 19 & 13 & $3,765.59$ & $3,764.70$ & -0.89 \\
\hline $31^{\circ} 59^{\prime} 28^{\prime \prime}$ & $106^{\circ} 40^{\prime} 23^{\prime \prime}$ & $27 \mathrm{~S} .3 \mathrm{E} .6 .231$ & 19 & 19 & $3,782.88$ & $3,783.50$ & 0.62 \\
\hline $31^{\circ} 59^{\prime} 53^{\prime \prime}$ & $106^{\circ} 40^{\prime} 39^{\prime \prime}$ & 26 S. 3E. 31.341 & 19 & 20 & $3,784.04$ & $3,787.30$ & 3.26 \\
\hline $32^{\circ} 18^{\prime} 53^{\prime \prime}$ & $106^{\circ} 50^{\prime} 40^{\prime \prime}$ & $23 \mathrm{~S} .1 \mathrm{E} .9 .433$ & 19 & 51 & $3,890.87$ & $3,889.50$ & -1.37 \\
\hline $31^{\circ} 49^{\prime} 20^{\prime \prime}$ & $106^{\circ} 34^{\prime} 38^{\prime \prime}$ & $\mathrm{JL}-49-12-502$ & 20 & 4 & $3,752.15$ & $3,731.30$ & -20.85 \\
\hline $31^{\circ} 51^{\prime} 52^{\prime \prime}$ & $106^{\circ} 35^{\prime} 39^{\prime \prime}$ & $\mathrm{JL}-49-12-103$ & 20 & 7 & $3,747.55$ & $3,743.40$ & -4.15 \\
\hline $32^{\circ} 00^{\prime} 44^{\prime \prime}$ & $106^{\circ} 40^{\prime} 41^{\prime \prime}$ & $26 \mathrm{~S} .3 \mathrm{E} .30 .343$ & 20 & 21 & $3,789.23$ & $3,789.00$ & -0.23 \\
\hline $32^{\circ} 15^{\prime} 44^{\prime \prime}$ & $106^{\circ} 48^{\prime} 08^{\prime \prime}$ & 23S.1E. 35.424 & 20 & 42 & $3,861.49$ & $3,870.60$ & 9.11 \\
\hline $32^{\circ} 19^{\prime} 21 "$ & $106^{\circ} 50^{\prime} 01^{\prime \prime}$ & 23 S.1E.10.134 & 20 & 51 & $3,893.93$ & $3,889.50$ & -4.43 \\
\hline $31^{\circ} 48^{\prime} 54^{\prime \prime}$ & $106^{\circ} 34^{\prime} 01^{\prime \prime}$ & $\mathrm{JL}-49-12-501$ & 21 & 4 & $3,729.80$ & $3,732.30$ & 2.50 \\
\hline $31^{\circ} 56^{\prime} 39^{\prime \prime}$ & $106^{\circ} 38^{\prime} 04^{\prime \prime}$ & 27 S. 3E. 21.421 & 21 & 15 & $3,765.74$ & $3,769.90$ & 4.16 \\
\hline $31^{\circ} 59^{\prime} 10^{\prime \prime}$ & $106^{\circ} 39^{\prime} 13^{\prime \prime}$ & 27S.3E. 5.414 & 21 & 19 & $3,776.12$ & $3,783.90$ & 7.78 \\
\hline $32^{\circ} 00^{\prime} 41^{\prime \prime}$ & $106^{\circ} 39^{\prime} 45^{\prime \prime}$ & 26S.3E. 29.334 & 21 & 20 & $3,786.85$ & $3,786.50$ & -0.35 \\
\hline $32^{\circ} 03^{\prime} 36^{\prime \prime}$ & $106^{\circ} 41^{\prime} 11^{\prime \prime}$ & $26 \mathrm{~S} .2 \mathrm{E} .12 .421$ & 21 & 24 & $3,805.12$ & $3,801.10$ & -4.02 \\
\hline $32^{\circ} 26^{\prime} 11^{\prime \prime}$ & $106^{\circ} 53^{\prime} 09^{\prime \prime}$ & 21S.1W. 36.221 & 21 & 60 & $3,932.88$ & $3,937.20$ & 4.32 \\
\hline $32^{\circ} 27^{\prime} 17^{\prime \prime}$ & $106^{\circ} 53^{\prime} 31^{\prime \prime}$ & 21 S.1W. 25.232 & 21 & 61 & $3,942.00$ & $3,940.40$ & -1.60 \\
\hline $31^{\circ} 55^{\prime} 51^{\prime \prime}$ & $106^{\circ} 37^{\prime} 22^{\prime \prime}$ & $\mathrm{JL}-49-04-407$ & 22 & 13 & $3,763.27$ & $3,760.30$ & -2.97 \\
\hline $31^{\circ} 55^{\prime} 52^{\prime \prime}$ & $106^{\circ} 37^{\prime} 11^{\prime \prime}$ & $\mathrm{JL}-49-04-408$ & 22 & 13 & $3,762.56$ & $3,760.30$ & -2.26 \\
\hline $31^{\circ} 57^{\prime} 48^{\prime \prime}$ & $106^{\circ} 37^{\prime} 58^{\prime \prime}$ & 27S.3E.16.224 & 22 & 17 & $3,771.76$ & $3,777.00$ & 5.24 \\
\hline
\end{tabular}


Table 6.--Differences between measured and model-derived

hydraulic heads--Continued

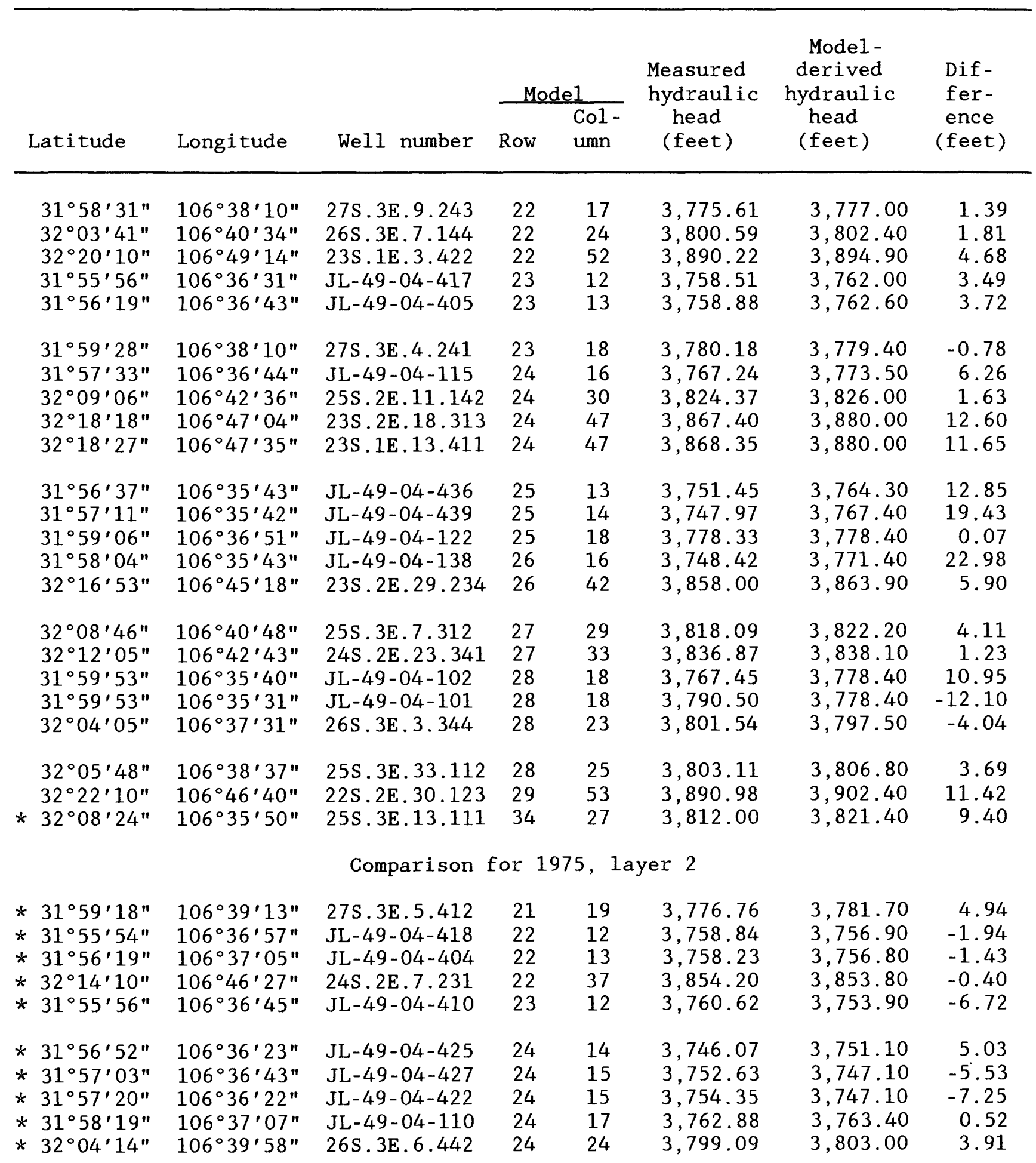


Table 6.--Differences between measured and model-derived hydraulic heads--Continued

\begin{tabular}{|c|c|c|c|c|c|c|c|}
\hline Latitude & Longitude & We11 number & Row & $\begin{array}{l}\frac{\mathrm{el}}{\mathrm{Col}-} \\
\text { umn }\end{array}$ & $\begin{array}{l}\text { Measured } \\
\text { hydraulic } \\
\text { head } \\
\text { (feet) }\end{array}$ & $\begin{array}{c}\text { Model- } \\
\text { derived } \\
\text { hydraulic } \\
\text { head } \\
\text { (feet) }\end{array}$ & $\begin{array}{l}\text { Dif- } \\
\text { fer- } \\
\text { ence } \\
\text { (feet) }\end{array}$ \\
\hline * $31^{\circ} 58^{\prime} 03^{\prime \prime}$ & $106^{\circ} 35^{\prime} 43^{\prime \prime}$ & $\mathrm{JL}-49-04-165$ & 26 & 16 & $3,737.46$ & $3,753.80$ & 16.34 \\
\hline * $32^{\circ} 16^{\prime} 23^{\prime \prime}$ & $106^{\circ} 44^{\prime} 56^{\prime \prime}$ & 23 S. 2 E. 28.333 & 26 & 41 & $3,838.00$ & $3,839.20$ & 1.20 \\
\hline * $32^{\circ} 19^{\prime} 14^{\prime \prime}$ & $106^{\circ} 46^{\prime} 25^{\prime \prime}$ & $23 \mathrm{~S} .2 \mathrm{E} .7 .411$ & 27 & 48 & $3,856.72$ & $3,853.70$ & -3.02 \\
\hline$* 32^{\circ} 18^{\prime} 32^{\prime \prime}$ & $106^{\circ} 45^{\prime} 13^{\prime \prime}$ & 23 S. 2 E. 17.243 & 28 & 46 & $3,834.68$ & $3,826.30$ & -8.38 \\
\hline * $32^{\circ} 18^{\circ} 53^{\prime \prime}$ & $106^{\circ} 45^{\prime} 21^{\prime \prime}$ & $23 \mathrm{~S} .2 \mathrm{E} .8 .443$ & 28 & 47 & $3,815.91$ & $3,841.10$ & 25.19 \\
\hline * $32^{\circ} 22^{\prime} 20^{\prime \prime}$ & $106^{\circ} 47^{\prime} 10^{\prime \prime}$ & 22 S.IE.25.222 & 28 & 53 & $3,897.70$ & $3,897.20$ & -0.50 \\
\hline * $32^{\circ} 18^{\prime} 19^{\prime \prime}$ & $106^{\circ} 44^{\prime} 52^{\prime \prime}$ & 23S.2E.16.314 & 29 & 45 & $3,819.71$ & $3,819.30$ & -0.41 \\
\hline * $32^{\circ} 19^{\prime} 56^{\prime \prime}$ & $106^{\circ} 45^{\prime} 31^{\prime \prime}$ & 23S. 2E. 5.342 & 29 & 49 & $3,836.79$ & $3,854.40$ & 17.61 \\
\hline
\end{tabular}

Comparison for 1975, layer 3

$\begin{array}{lll}* 31^{\circ} 56^{\prime} 27^{\prime \prime} & 106^{\circ} 36^{\prime} 37^{\prime \prime} \\ * 31^{\circ} 57^{\prime} 03^{\prime \prime} & 106^{\circ} 36^{\prime} 43^{\prime \prime} \\ * 31^{\circ} 57^{\prime} 17^{\prime \prime} & 106^{\circ} 36^{\prime} 40^{\prime \prime} \\ * 31^{\circ} 58^{\prime} 03^{\prime \prime} & 106^{\circ} 36^{\prime} 45^{\prime \prime} \\ * 31^{\circ} 58^{\prime} 17^{\prime \prime} & 106^{\circ} 37^{\prime} 06^{\prime \prime} \\ & \\ * 32^{\circ} 16^{\prime} 40^{\prime \prime} & 106^{\circ} 46^{\prime} 12^{\prime \prime} \\ * 32^{\circ} 05^{\prime} 50^{\prime \prime} & 106^{\circ} 38^{\prime} 15^{\prime \prime}\end{array}$

* $32^{\circ} 01^{\prime} 12^{\prime \prime}$

$* 31^{\circ} 53^{\prime} 29^{\prime \prime}$

$* 31^{\circ} 56^{\prime} 10^{\prime \prime}$

$* 32^{\circ} 02^{\prime} 30^{\prime \prime}$

*31 $41^{\circ} 11^{\prime \prime}$

* $31^{\circ} 48^{\prime} 12^{\prime \prime}$

* $32^{\circ} 04^{\prime} 28^{\prime \prime}$

* $31^{\circ} 49^{\prime} 12^{\prime \prime}$

* 32 $03^{\circ} 09^{\prime \prime}$

* $31^{\circ} 59^{\prime} 55^{\prime \prime}$

* 32 $06^{\circ} 57^{\prime \prime}$

* $32^{\circ} 12^{\prime} 41^{\prime \prime}$

* $32^{\circ} 09^{\prime} 27^{\prime \prime}$

* $31^{\circ} 51^{\prime} 48^{\prime \prime}$

* $31^{\circ} 57^{\prime} 03^{\prime \prime}$

\begin{abstract}
$107^{\circ} 04^{\prime} 57^{\prime \prime}$
$106^{\circ} 59^{\prime} 33^{\prime \prime}$

$107^{\circ} 00^{\prime} 20^{\prime \prime}$

$107^{\circ} 01^{\prime} 35^{\prime \prime}$

$106^{\circ} 51^{\prime} 46^{\prime \prime}$

$106^{\circ} 51^{\prime} 45^{\prime \prime}$

$106^{\circ} 56^{\prime} 39^{\prime \prime}$

$106^{\circ} 46^{\prime} 47^{\prime \prime}$

$106^{\circ} 52^{\prime} 16^{\prime \prime}$

$106^{\circ} 49^{\prime} 00^{\prime \prime}$

$106^{\circ} 52^{\prime} 19^{\prime \prime}$

$106^{\circ} 55^{\prime} 58^{\prime \prime}$

$106^{\circ} 53^{\prime} 13^{\prime \prime}$

$106^{\circ} 42^{\prime} 07^{\prime \prime}$

$106^{\circ} 4^{\prime} 01^{\prime \prime}$
\end{abstract}

$3,738.59$

$3,724.90$

$3,712.70$

$3,719.34$

$3,724.64$

JL-49-04-113

23S. 2E. 30.243

25S. 3E. 28.434

29

$3,849.00$

$3,808.00$

Comparison for 1984-85, 1ayer 1

$\begin{array}{lll}26 S .2 W .30 .233 & 1 & 31 \\ 28 S .1 W .7 .113 B & 2 & 20 \\ 27 S .2 W .25 .111 & 3 & 23 \\ 26 S .2 W .15 .434 & 3 & 31 \\ 29 S .1 E .6 .111 & 5 & 10\end{array}$

$3,844.00$
$3,801.00$
$3,805.00$
$3,841.00$
$3,803.00$

$3,862.70$

$3,810.50$

$3,814.90$

$3,841.80$

$3,793.30$

29S.1E.8.124 $5 \quad 10$

$26 \mathrm{~S} .1 \mathrm{~W} .4 .412$

29S. 2E.6.122B

26S.1E. 18.222B

26S.1E. 35.332

$3,797.00$

$3,826.00$

$3,800.00$

$3,820.00$

$3,800.00$

25S.1E.19.424A 9

24S.1W.22.121 9

25S.1E.6.331 10

28S.2E.23.222 11

27S.2E. 21.111

11
$3,847.00$

$3,876.00$

$3,840.00$

$3,777.00$

$3,788.00$
$3,793.30$

$3,826.20$

$3,785.90$

$3,819.50$

$3,805.50$

$3,829.40$

$3,847.50$

$3,838.30$

$3,773.60$

$3,788.90$
10.81

$-15.80$

$-3.60$

$-0.14$

19.76

10.80

$-0.20$

18.70

9.50

9.90

0.80

$-9.70$

$-3.70$

0.20

$-14.10$

$-0.50$

5.50

$-17.60$

$-28.50$

$-1.70$

$-3.40$

0.90 
Table 6.--Differences between measured and model-derived hydraulic heads--Concluded

\begin{tabular}{|c|c|c|c|c|c|c|c|}
\hline \multirow[b]{2}{*}{ Latitude } & \multirow[b]{2}{*}{ Longitude } & \multirow[b]{2}{*}{ Well number } & \multicolumn{2}{|c|}{ Model } & \multirow{2}{*}{$\begin{array}{c}\text { Measured } \\
\text { hydraulic } \\
\text { head } \\
\text { (feet) }\end{array}$} & \multirow{2}{*}{$\begin{array}{l}\text { Model- } \\
\text { derived } \\
\text { hydraulic } \\
\text { head } \\
\text { (feet) }\end{array}$} & \multirow{2}{*}{$\begin{array}{l}\text { Dif- } \\
\text { fer- } \\
\text { ence } \\
\text { (feet) }\end{array}$} \\
\hline & & & Row & $\begin{array}{l}\text { Col - } \\
\text { umn }\end{array}$ & & & \\
\hline * $31^{\circ} 51^{\prime} 01^{\prime \prime}$ & $106^{\circ} 41^{\prime} 07^{\prime \prime}$ & $28 \mathrm{~S} .2 \mathrm{E} .24 .444$ & 12 & 8 & $3,766.00$ & $3,764.30$ & -1.70 \\
\hline * $31^{\circ} 59^{\prime} 51^{\prime \prime}$ & $106^{\circ} 46^{\prime} 07^{\prime \prime}$ & $26 \mathrm{~S} .2 \mathrm{E} .32 .333$ & 12 & 22 & $3,795.00$ & $3,799.40$ & 4.40 \\
\hline * $31^{\circ} 49^{\circ} 48^{\prime \prime}$ & $106^{\circ} 39^{\prime} 41^{\prime \prime}$ & $28 \mathrm{~S} .3 \mathrm{E} .32 .143$ & 13 & 7 & $3,766.00$ & $3,758.30$ & -7.70 \\
\hline * $32^{\circ} 16^{\prime} 17^{\prime \prime}$ & $106^{\circ} 53^{\prime} 15^{\prime \prime}$ & $23 \mathrm{~S} .1 \mathrm{~W} .25 .444$ & 13 & 47 & $3,870.00$ & $3,867.30$ & -2.70 \\
\hline * $31^{\circ} 51^{\prime} 31^{\prime \prime}$ & $106^{\circ} 38^{\prime} 32^{\prime \prime}$ & 28S.3E.21.144 & 15 & 8 & $3,748.00$ & $3,752.80$ & 4.80 \\
\hline \multirow[t]{5}{*}{ * } & $106^{\circ} 39^{\prime} 23^{\prime \prime}$ & $28 \mathrm{~S} .3 \mathrm{E} .17 .214$ & 15 & 9 & $3,758.00$ & $3,753.30$ & -4.70 \\
\hline & $106^{\circ} 37^{\prime} 18^{\prime \prime}$ & 28 S. 3E. 27.434 & 16 & 6 & $3,750.00$ & $3,748.80$ & -1.20 \\
\hline & $106^{\circ} 44^{\prime} 05^{\prime \prime}$ & 25S.2E.28.222B & 19 & 28 & $3,818.00$ & $3,817.70$ & -0.30 \\
\hline & $106^{\circ} 37^{\prime} 31^{\prime \prime}$ & 26S.3E. 3.344D & 29 & 23 & $3,801.00$ & $3,799.20$ & -1.80 \\
\hline & & Comparison for & \multicolumn{3}{|c|}{ r 1984-85, layer 2} & & \\
\hline * $32^{\circ} 02^{\prime} 55^{\prime \prime}$ & $106^{\circ} 57^{\prime} 08^{\prime \prime}$ & $26 \mathrm{~S} .1 \mathrm{~W} .16 .334$ & 6 & 29 & $3,821.00$ & $3,822.60$ & 1.60 \\
\hline * $32^{\circ} 08^{\prime} 26^{\prime \prime}$ & $106^{\circ} 51^{\prime} 12^{\prime \prime}$ & 25S.1E.16.111 & 11 & 33 & $3,837.00$ & $3,833.20$ & -3.80 \\
\hline * $32^{\circ} 05^{\prime} 20^{\prime \prime}$ & $106^{\circ} 46^{\prime} 57^{\prime \prime}$ & 25S.2E.31.312B & 313 & 28 & $3,821.00$ & $3,818.00$ & -3.00 \\
\hline * $32^{\circ} 13^{\prime} 35^{\prime \prime}$ & $106^{\circ} 47^{\prime} 21^{\prime \prime}$ & $24 \mathrm{~S} .1 \mathrm{E} .13 .221 \mathrm{~A}$ & 20 & 37 & $3,853.00$ & $3,853.40$ & 0.40 \\
\hline * $32^{\circ} 17^{\prime} 45^{\prime \prime}$ & $106^{\circ} 49^{\prime} 21^{\prime \prime}$ & 23S.1E. 22.241A & 20 & 47 & $3,872.00$ & $3,874.50$ & 2.50 \\
\hline * $31^{\circ} 55^{\prime} 54^{\prime \prime}$ & $106^{\circ} 36^{\prime} 57^{\prime \prime}$ & $J L-49-04-418$ & 22 & 12 & $3,732.00$ & $3,751.50$ & 19.50 \\
\hline * $32^{\circ} 14^{\prime} 10^{\prime \prime}$ & $106^{\circ} 46^{\prime} 27^{\prime \prime}$ & 24 S. 2E. 7.231 & 22 & 37 & $3,854.00$ & $3,852.40$ & -1.60 \\
\hline * $32^{\circ} 17^{\prime} 40^{\prime \prime}$ & $106^{\circ} 48^{\prime} 10^{\prime \prime}$ & 23S.1E.23.244A & 22 & 46 & $3,867.00$ & $3,869.40$ & 2.40 \\
\hline * $32^{\circ} 12^{\prime} 39^{\prime \prime}$ & $106^{\circ} 44^{\prime} 45^{\prime \prime}$ & 24S.2E.21.123 & 24 & 35 & $3,842.00$ & $3,844.20$ & 2.20 \\
\hline * $31^{\circ} 57^{\prime} 12^{\prime \prime}$ & $106^{\circ} 36^{\prime} 12^{\prime \prime}$ & JL-49-04-480 & 25 & 14 & $3,730.00$ & $3,745.60$ & 15.60 \\
\hline
\end{tabular}

Summary

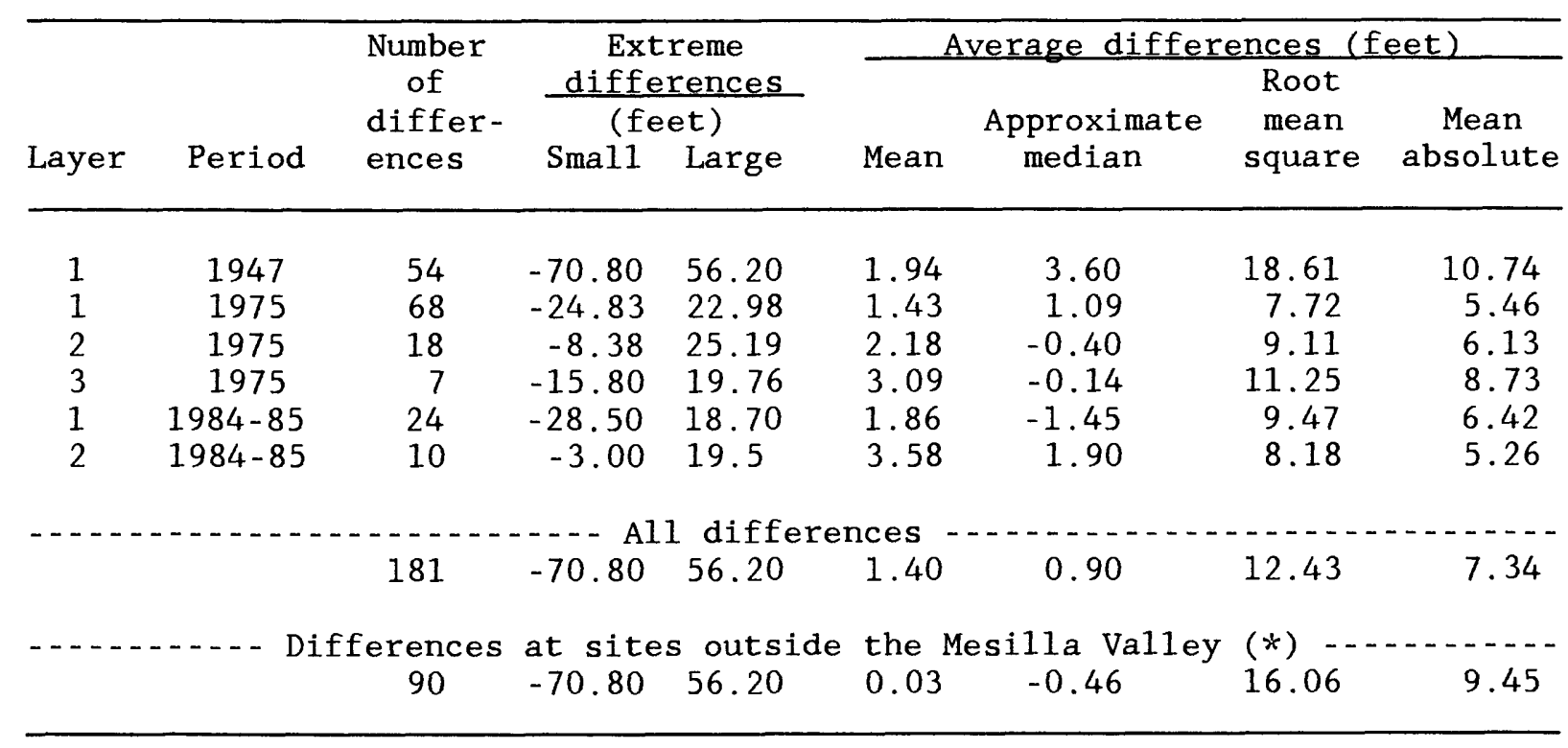


Table 7.-- Average differences, in feet, between model-derived and measured hydraulic heads for the standard

and each sensitivity test

[Averages included 90 differences for 1947, 1975, and 1984-85. Approximate median is the average of the two values nearest the median]

\begin{tabular}{lcrrr}
\hline $\begin{array}{c}\text { Abbreviated } \\
\text { test name }\end{array}$ & $\begin{array}{c}\text { Arith- } \\
\text { metic } \\
\text { mean }\end{array}$ & $\begin{array}{c}\text { Mean } \\
\text { absolute }\end{array}$ & $\begin{array}{c}\text { Approx- } \\
\text { imate } \\
\text { median }\end{array}$ & $\begin{array}{c}\text { Root } \\
\text { mean } \\
\text { square }\end{array}$ \\
\hline S 0.3 1.5E-6 & 0.23 & 9.44 & -0.25 & 16.09 \\
STANDARD & -0.03 & 9.45 & -0.46 & 16.06 \\
S 0.40 2.E-6 & 0.41 & 9.45 & -0.05 & 16.13 \\
KMSFD7 3 & -0.24 & 9.49 & -0.45 & 16.03 \\
KMSFD15 8 & 0.19 & 9.50 & -0.57 & 16.14 \\
S 0.13.67E-6 & -0.32 & 9.52 & -0.60 & 16.06 \\
KLSF20 & 0.57 & 9.66 & -0.47 & 16.29 \\
ANISOTROPY 150,750,750,150 & -0.86 & $9.67-$ & -1.70 & 15.98 \\
ANISOTROPY 67,333,333,67 & 0.61 & 9.78 & 0.00 & 16.39 \\
KUSF45 18 & 1.00 & 9.79 & 0.51 & 16.37 \\
KUSF20 8 & -1.27 & 9.86 & -1.47 & 16.26 \\
KLSF9 & -0.67 & 9.98 & -0.31 & 16.53 \\
KMSFS30 15 & -0.96 & 10.00 & -0.98 & 16.61 \\
KMSFS13 7 & 1.17 & 10.25 & 0.35 & 16.74
\end{tabular}

Explanation of abbreviated test names:

S $0.3 \quad 1.5 \mathrm{E}-6$

STANDARD
Specific yield (layers 1 and 2) set to 0.3 and specific storage (layers $2-4$ ) set to $1.5 \times 10-6$ per foot.

The standard is the model described in this report with no changes. Hydraulic-conductivity values of the standard, using the abbreviations explained below, were as follows:

$\mathrm{KUSF}=30$ and 12 feet per day, KMSFS $=20$ and 10 feet per day, $\mathrm{KMSFD}=10$ and 5 feet per day, and KLSF $=13$ feet per day.

Horizontal to vertical hydraulic-conductivity anisotropy ratios were:

100:1 for the river alluvium, 500:1 for the upper and middle

hydrostratigraphic units of the Santa $\mathrm{Fe}$ Group, and

100:1 for the lower hydrostratigraphic units of the Santa Fe Group.

Specific yield for layers 1 and 2 was 0.2 , and specific storage for layers $2-4$ was 1 × 10-6 foot of thickness. 
Table 7.--Average differences, in feet, between model-derived and

measured hydraulic heads for the standard

and each sensitivity test--Concluded

Explanation of abbreviated test names:

S $0.402 . \mathrm{E}-6$

KMSFD7 3

KMSFD15 8

S $0.13 \quad .67 \mathrm{E}-6$

KLSF20

ANISOTROPY $150,750,750,150$

ANISOTROPY $67,333,333,67$

KUSF45 18

(KUSF)

KUSF20 8

KLSF9

KMSFS30 15

KMSFS13 7
Specific yield (layers 1 and 2) set to 0.4 and specific storage (layers 2-4) set to $2 \times 10-6$ per foot.

Hydraulic conductivity of the deep part of the middle hydrostratigraphic unit of the Santa $\mathrm{Fe}$ Group (KMSFD) set to 3 feet per day in the Las Cruces area (rows 25-36, columns 35-64) and 7 feet per day elsewhere.

KMSFD set to 8 feet per day in the Las Cruces area and 15 feet per day elsewhere.

Specific yield (layers 1 and 2) set to 0.13 and specific storage (1ayers 2-4) set to $6.7 \mathrm{E}-7$.

Hydraulic conductivity of the lower hydrostratigraphic unit of the Santa Fe Group set to 20 feet per day throughout the model.

Horizontal to vertical anisotropy ratios set to 150 for the river alluvium, 750 for the upper and middle hydrostratigraphic units of the Santa Fe Group, and 150 for the lower hydrostratigraphic unit of the Santa Fe Group.

Horizontal to vertical anisotropy ratios set to 67 for the river alluvium, 333 for the upper and middle hydrostratigraphic units of the Santa $\mathrm{Fe}$ Group, and 67 for the lower hydrostratigraphic unit of the Santa Fe Group.

Hydraulic conductivity of the upper hydrostratigraphic unit of the Santa Fe Group set to 18 feet per day in the Las Cruces area and 45 feet per day elsewhere.

KUSF set to 8 feet per day in the Las Cruces area and 20 feet per day elsewhere.

KLSF set to 9 feet per day throughout the model.

Hydraulic conductivity of the shallow part of the middle hydrostratigraphic unit of the Santa Fe Group set to 15 feet per day in the Las Cruces area and 30 feet per day elsewhere.

KMSFS set to 7 feet per day in the Las Cruces area and 13 feet per day elsewhere. 